(a)

$2 K 374$ P3 
QK 374.P3 ${ }^{\text {Cornell University Library }}$

Studies on the vegetation of the Transca

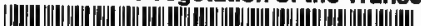

31924001827819 


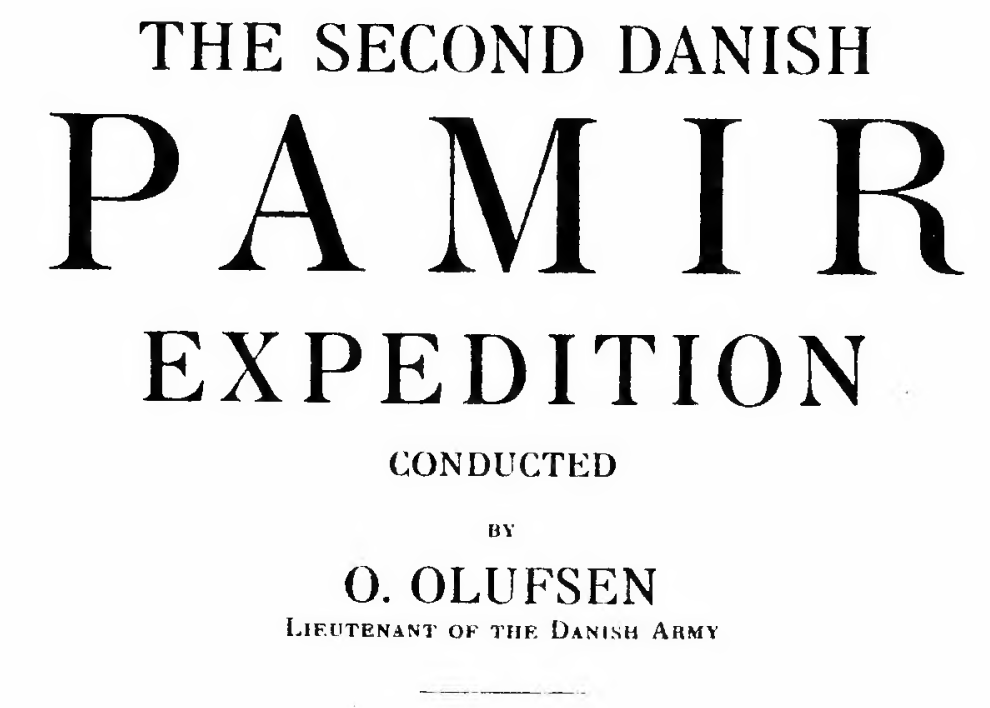

\title{
STUDIES ON THE VEGETATION OF THE TRANSCASPIAN LOWLANDS
}

BY

\author{
OVE PAULSEN \\ MeMBer of THE Expention
}

WITH 79 FIGURES AND A MAP

'UBLISHED AT THE EXPENSE OF THE CHURCH- AND SCHOOL DEPARTMENT AND THE CARLSBERG FUND

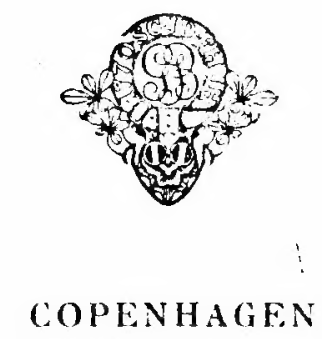

GYLDENDALSKE BOGHANDEL · NORDISK FORLAG 


\section{Cornell University Library}

The original of this book is in the Cornell University Library.

There are no known copyright restrictions in the United States on the use of the text.

http://www.archive.org/details/cu31924001827819 




\section{THE SECOND DANISH PAMIR EXPEDITION}





\section{THE SECOND DANISH PAMIR EXPEDITION}

CONDUCTED

BY

O. OLUFSEN

Lieutenant of the Danish Army

\section{STUDIES ON THE VEGETATION \\ OF THE TRANSCASPIAN LOWLANDS}

BY

OVE PAULSEN

Member of the Expedition

WITH 79 FIGURES AND A MAP

PUBLISHED AT THE EXPENSE OF THE CHURCH- AND

SCHOOL DEPARTMENT AND THE CARLSBERG FUND

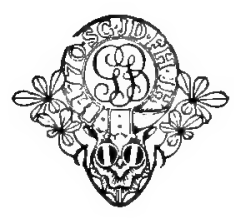

COPENHAGEN

GYLDENDALSKE BOGHANDEL · NORDISK FORLAG 1912

Arbejder fra den botaniske Have i København. Nr. 90. 


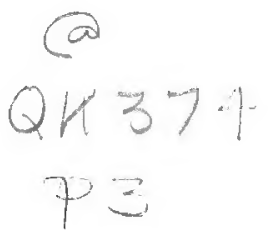

a 2192

PRINTED BY GRAPE - COPENHAGEN 


\section{OVE PAULSEN STUDIES ON THE VEGETATION OF THE TRANSCASPIAN LOWLANDS}



7 His paper has been published in Danish under the title I "Træk af Vegetationen i Transkaspiens Lavland» (København 1911, Gyldendal), and in "Botanisk Tidsskrift«, Vol. 32. The present edition is issued with but slight alterations. The translation has been revised and corrected by Dr. W. G. Smith, of the College of Agriculture, Edinburgh, who has assisted also in proof-reading. I would offer Dr. Sмirн my sincere thanks for his valuable assistance without which it would hardly have been possible to find correct English equivalents for Danish botanical terms.

A Russian edition is under preparation.

The author. 



\section{CONTENTS.}

Page

........................ 1

Section I. Transcaspia and its natural conditions . . . . . . . . . 3

Chapter 1. Situation and boundary of the region examined . . . 3

Chapter 2. Features of the geology of Transcaspia. . . . . . . . 6

Chapter 3. General aspects of the climate of Transcaspia . . . . 11

Section II. The vegetation of the Transcaspian lowlands . . . . . 18

Chapter 4. Earlier literature . . . . . . . . . . . . . . . . . 18

Chapter 5. Classification of formations . . . . . . . . . . . . 43

Chapter 6. The formation of the Salt-deserts . . . . . . . 50

Chapter 7. The formation of the Clay-deserts . . . . . . . . . 56

Chapter 8. The formation of the Stone-deserts . . . . . . . . . 74

Chapter 9. The formation of the Sand-deserts . . . . . . . . . 77

Chapter 10. The Riverside Thickets (Bushland) . . . . . . . 109

Chapter 11. Description of vegetation from selected localities . . 120

Section III. Growth-forms . . . . . . . . . . . . . . . . . . . 135

Chapter 12. Plant-list and statistics . . . . . . . . . . 135

Chapter 13. Descriptions of the growth-forms . . . . . . . . . 173

A. Fanerophytes . . . . . . . . . . . 174

B. Chamaephytes . . . . . . . . . . . . . 215

C. Hemicryptophytes . . . . . . . . . . . . . . . . 232

D. Geophytes . . . . . . . . . . . . . . 237

E. Therophytes . . . . . . . . . . . . . . 241

Section IV. The flora of the Transcaspian lowlands. . . . . . . 258

Chapter 14. The elements of the flora . . . . . . . . . . . . 258 


\title{
SECTION I. TRANSCASPIA AND ITS NATURAL CONDITIONS
}

\author{
CHAPTER I
}

\section{Situation and Boundaries of the Region examined.}

HE great tract of lowlands, a southern extension of the

West-Siberian plain, stretching from the Caspian Sea to the country round Lake Balchash, and having as its southern boundary the mountains of northern Persia, the Thianshan and Ala-tau and which is in open communication with the south of Russia, to the north-west, through the plains north of the Caspian Sea, cannot strictly be designated as belonging to those portions of the continent which are without drainage to the sea. The $»$ Duab* or »country with two streams versed by the two great rivers Amu and Syr, both flowing into the Aral Sea, is of the type designated by RichthófEN as a peripheral region, that is a region whose waters are carried by rivers to the sea, or to remnants of sea which are now lakes. Richthofen's Central Asia, on the contrary, includes the areas in the interior of Asia which are devoid of any drainage to the sea. Here the wind is the principal geological agent, and all the products of chemical or mechanical disintegration remain in the country; they are only moved from one place to another, filling up the hollows and thus imparting a monotonous aspect to the country. While, as Richthofen remarks, the movement in Central Asia is centripetal, it is centrifugal in the peripheral regions, 
The systematic part of the botanical results of this journey have been published from time to time as the examination of the separate families was completed. ${ }^{1}$ )

This memoir is the first part of the biological section of the botanical results of the expedition, and includes the vegetation of the lowlands.

As the expedition never remained long in one place, there was not much opportunity for thorough investigation of the desert in any locality, so that this memoir is the result of observations in many parts most of which were only examined for a short time. Physiognomy therefore occupies a prominent place in this description of a type of vegetation which in detail would constitute an extensive research. It is to be hoped that detailed investigations, such as those made at the desert laboratory in Tuczon (Arizona) or similar to Fitring's researches in the Sahara will also be made in the Transcaspian desert, so characteristic and worthy of careful examination.

1) These publications are located as follows: Videnskabelige Meddelelser fra den naturhistoriske Forening i Kbhvn. 1901 - Caryophyllaceae, Ranunculaceae; in the same periodical for 1903 - Cruciferae, Umbelliferae, Valerianaceae, Compositae, Gramineae, Potamogetonaceae, Chenopodiaceae; Botanisk Tidsskrift Vol. 26 - Pteridophyta, Gnetaceae, Cupressaceae, Lemnaceae, Typhaceae, Juncaginaceae, Alismaceae, Typhaceae, Juncaginaceae, Alismaceae, Liliaceae, Convallariaceae, Amaryllidaceae, Iridaceae, Juncaceae, Orchidaceae, Salicaceae, Cupuliferae, Urticaceae, Cannabaceae, Polygonaceae; in Botanisk Tidsskxift Vol. 27 - Amarantaceae, Phytolaccaceae, Berberidaceae, Ceratophyllaceae, Papaveraceae, Fumariaceae, Resedaceae, Violaceae, Frankeniaceae, Tamaricaceae, Euphorbiaceae, Oxalidaceae, Linaceae, Geraniaceae, Balsaminaceae, Malvaceae, Rutaceae, Zygophyllaceae. Polygalaceae, Ampelidaceae, Rhamnaceae, Thymelaeaceae, Elaeagnaceae, Saxifragaceae, Ribesiaceac, Hamamelídaceae, Rosaceae, Lythraceae, Oenotheraceae, Haloragidaceae, Myrtaccae, Loranthaceae, Primulaceae, Convolvulaceae, Solanaceae, Plantaginaceae, Bignoniaceae, Apocynaceae, Asclepiadaceae, Rubiaceae, Caprifoliaceae, Dipsacaceae, Scrophulariaceae, Borraginiaceae; Botanisk Tidsskrift Vol. 28 Fungi, Cyperaceae, Labiatae; Bulletin de l'Herbier Boissier VI - Papilionaceae; Botanisk Tidsskrift Vol. 29 - Additions and Corrections. 
Missing Page 
Missing Page 
Missing Page 
argument applies to the name "Turan" which covers MushkETow's "Turkestan". The "Aral-Basin" would better designate our territory, but this name also includes the Kirghiz Steppe. The designation Transcaspian Plain or Lowlands or briefly Transcaspia has finally been selected as most appropriate. The same name has been used to indicate an administrative unit of the Russian empire, the government Transcaspia, which extended almost to the Amu Darya, to the borders of the vassal state of Buchara.

In thus designating my territory Transcaspia it should be emphasised that though to the east it stretches to Kara Tau, I do not use this name as defining a geographical area, but only as a name for a territory the borders of which I have determined myself, and which lies beyond the Caspian Sea.

\section{CHAPTER 2}

\section{Features of the Geology of Transcaspia.}

Turkestan and Central Asia are supposed to have been covered by the sea during the Cretaceous and Tertiary periods, and even on the mountains at a height of 11,000 feet, Tertiary deposits have been found (Mushiktow).

This sea receded from Hanhai earlier than from the plain of Turkestan, and of this country the eastern part was the first part to become dry. During the Miocene period the brackish Sarmatian inland sea connected the Aral, the Caspian and the Black Sea (Karpinsiri). At a later period, probably contemporaneous with the great Scandinavian glacial period and when there was much water from the melting ice, there existed a sea (the Aralo-Caspian Basin) which filled the depressions now occupied by the Caspian Sea and the Aral Sea, connecting them by a narrow straight (Karpinski, SJöGREN).

Almost all the lowlands of Turkestan (95 per ct. according to Mushketow) are thus covered with deposits from the Cretaceous and Tertiary periods. Through these, islands of 
older rocks emerge, for instance Tamdi-Tau, Bukan-Tau, Sultan Uis Dagh, now isolated mountainous masses consisting of various slates and crystalline rocks which as a result of greater denudation are now more cut up than the rocks of Thianshan.

The deposits from the Cretaceous and Tertiary periods are of great thickness, attaining 5000 feet in Ferghana for instance. They consist of diverse coloured strata of marl, limestone, ferruginous sandstones, gypsum, clay \&c. They are not identical everywhere but change according to the nearness of the mountains: At the foot of the mountains, marginal deposits are found, such as shelly limestones, conglomerates, clay with gypsum and rock-salt, while, out on the flat land, sand and clay are found deposited in deeper water (Romanowshi, Mushiketow).

The Tertiary deposits, however, are rarely visible, as they are almost everywhere covered by newer deposits partly derived from them. Of these the most important are: the moving sands, the Aralo-Caspian deposits and the loess.

Deserts of moving sand cover, according to RoDSEwITCH, about 88 per ct. of the lowland. The sand is of varied origin. In the northern part it is derived from old Aralian sea-coast dunes and is white or grey. As this sand originates from the old Aralo-Caspian Basin, it has much the same distribution as the Aralo-Caspian deposits mentioned below.

Throughout the rest of the moving-sand territory, the dunes ("Barchans") are genuine inland deposits which owe their origin purely to the wind. The wind carries off everything available, all that mechanical disintegration provides for it. Thus the Aralian dunes, the Aralo-Caspian deposits and the older rocks contribute to the formation of the "Barchans". Illustrations of the effects of the levelling process will be found in Berg.-- The Barchans are of a dirty yellow colour, they have the shape of a crescent, generally quite regular. The convex part faces the wind, the inclination of the surface is here $6-16^{\circ}$, while on the lee side it is $30-38^{\circ}$ (Mushketow). The crest is a sharp and regular line, which from the highest point curves downwards and away from the wind. How the crescent shape is produced has been ex- 
plained by Middendorff, Walther (p. 122) and Solger (p. 149). In contrast to the dunes of western Europe, the barchans do not owe their occurrence to the sand having at first found shelter behind some obstacle, but they take that form which offers least resistance to the wind, hence they must be regarded as gigantic wave-lines in the sand. Good pictures of barchans may be seen in BESSEY.

Other forms of sand landscapes are dealt with in the chapter on the formation of the sand desert.

The Aralocaspian formations which originated in the post-pliocene Aralocaspian Basin consist of sandy clays deposited on the bottom of the basin. The area of the older sea was considerably larger than that of the present lakes; thus, its eastern part extended down both sides of the isolated mountains Bukan Tau and Sultan Uis Dagh so that these occupied a peninsula in the sea. As the sea dried up, many smaller lakes were left.

Loess, as is well known, is a calcareous loam intersected by innumerable irregular veins which often contain roots of plants. "Ein Leichenfeld von unzählbaren Generationen von Gräsern", as RichthofEn puts it (I, p. 71). Loess is now generally regarded as an eolian deposit derived from dust-drift, since the finest material shifted by the wind - if not taken right away - must sooner or later come to rest either in water or on a fixed "steppe", because the wind would carry it away again from any other place (RICHTHofen I, p. 98). In the first case the material will go to form stratified deposits on the sea-bottom, in the latter it will form land-loess which is not stratified.

In Turkestan Loess may attain a great thickness, according to Romanowski up to 1500 feet. It occurs more especially in the south-eastern, southern and eastern parts of the territory, but also occurs in patches in other places (MushkETOW).

Like all areas without drainage to the sea, the Transcaspian plains are rich in salts, since if the products of disintegration and chemical weathering cannot be taken out of the country, they must remain. Most of the Russian authors known to me are of opinion that the salts origin- 
ate from the old sea as the result of evaporation. But I am rather of the opinion of ANIKIN that the salts are mainly due to the constantly continued chemical weathering.

Chlorides and sulphates occur most frequently both in the soil of the desert and in the salt-lakes. These two groups of salts are often found separate, so that some lakes have mainly sodium chloride in solution, while others have mainly compounds of sodium and magnesium sulphates. The latter are called bitter-lakes. ANIKIN explains the difference in the following way. The wind assorts the material which has been crystallized out through evaporation. The common salt crystallizes out first and as a firm mass, then the sulphates crystallize later above this in loose powdery masses which later, when left dry, are carried off by wind, the firmer masses of sodium chloride being left as a coherent deposit.

In a supplement to MiddendorfF's memoir on Ferghana, Schmid gives a number of salt-analyses from which the following are selected:

1. Kara-Tjubé, salt-desert. Crystalline Powder with glaubersalt, gypsum, bitter-salt and clay:--

Salts soluble in water: 74,2045 per ct.

including: $\mathrm{Na}_{2} \mathrm{SO}_{4} 62,4834$ per ct.

$\begin{array}{lll}\mathrm{CaSo}_{4} & 8,5121 & - \\ \mathrm{MgSO}_{4} & 3,1500 & - \\ \mathrm{Al}_{2} \mathrm{O}_{3} & 6,9351 & -\end{array}$

2. Mojan. Efflorescence upon limestone:-

Salts soluble in water: 21,661 per ct.

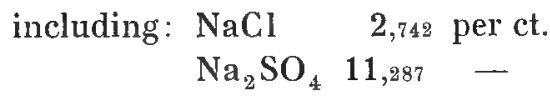

$\mathrm{CaSO}_{4} \quad 6,977 \quad--$

$\mathrm{CaCO}_{3} \quad 47,447 \quad-$ 
3. Kokan. Jany Kurgan. Salt crust on dry plant stems:Salts soluble in water: 49,9787 per ct. including: $\mathrm{Na}_{2} \mathrm{SO}_{4} 44,8090$ per ct.

$\begin{array}{lll}\mathrm{CaSO}_{4} & 3,2232 & - \\ \mathrm{MgSO}_{4} & 1,2510 & - \\ \mathrm{CaCO}_{3} & 4,7170 & - \\ \mathrm{NaCl} & 0,2891 & -\end{array}$

4. Margilan. Alty Aryk. Snow-while salt-desert:-

Salts soluble in water: 26,6792 per ct. including: $\mathrm{Na}_{2} \mathrm{SO}_{3} \quad 9_{4,4161}$ per ct.

$\begin{array}{lrl}\mathrm{CaSO}_{4} & 10,1121 & - \\ \mathrm{MgSO}_{4} & 6,8053 & - \\ \mathrm{CaCO}_{3} & 5,9624 & - \\ \mathrm{NaCl} & 0,1236 & -\end{array}$

RADDE (1899 p. 22) gives the following analysis of a "Ssor", salt-patch in the desert: -

$\begin{array}{lcl}\mathrm{Na}_{2} \mathrm{SO}_{4} & 85,50 & \text { per ct. } \\ \mathrm{NaCl} & 8 & - \\ \mathrm{MgSO}_{4} & 3,50 & - \\ \mathrm{CaSO}_{4} & 0,68 & -\end{array}$

In the following the samples were collected by me and analysed by Mr. WöHLK, chemist:

1. Salt on the earth in a desert near Buchara.

A greyish-white, amorphous, flocculent, dusty powder consisting of: -

$$
\text { with } \mathrm{CaSO}_{4} \text {, about } 6 \text { per ct. }
$$$$
\text { and } \mathrm{NaCl} \text {, trace. }
$$

2. Rough firm saline crust from the same place: Salts soluble in water:

$$
\begin{aligned}
& \mathrm{CaSO}_{4} \text {, ab. 8,9 per ct. } \\
& \mathrm{Na}_{2} \mathrm{SO}_{4} \quad 5,4 \quad- \\
& \mathrm{MgSO}_{4} \quad 44, \overline{\mathrm{i}} \quad- \\
& \mathrm{NaCl} \quad 41,0 \quad-
\end{aligned}
$$


3. Pure white salt around the lake Jugur Kul, Chiwa. July $15^{\text {th }} 1899$ : -

$$
\begin{aligned}
& \mathrm{NaCl} \\
& \text { with } \mathrm{MgSO}_{4} \text {, ab. 3,7 per cl. } \\
& \text { and } \mathrm{MgCl}_{2}, \quad-1_{1,4}-
\end{aligned}
$$

4. In the same place. Salt around and encrusting the base of Salicornia plants: -

$$
\begin{array}{lcc}
\mathrm{MgSO}_{4}, & \text { ab. } & 21,0 \\
\mathrm{NaCl}, & \text { per ct. } \\
\mathrm{Na}_{2} \mathrm{SO}_{4}, & 76,9 & - \\
& 1,6 & -
\end{array}
$$

5. Salt from a dried-up water-hole near Chodsheli, Chiwa. July $26^{\text {th }} 1899$. A salt-cake consisting of six strata of colourless crystals lying one above another, and corresponding somewhat to the mineral Astrakanit: -

$$
\begin{aligned}
& \mathrm{NaCl}, \quad \mathrm{ab} .0,50 \text { per ct. } \\
& \mathrm{MgSO}_{4} \quad 36,7 \quad- \\
& \mathrm{Na}_{2} \mathrm{SO}_{4}, \quad 41,5 \quad- \\
& \text { Water } 31,3 \quad- \\
& \text { (including carbonate of } \mathrm{Mg} \text { or } \mathrm{Na} \text { ). }
\end{aligned}
$$

As will be seen, gypsum, glauber-salts, magnesium sulphate, carbonate of lime and common salt are the most frequent salts. Their mode of occurence will be dealt with later, especially in the chapter on salt-deserts.

\section{CHAPTER 3}

\section{General Aspects of the Climate of Transcaspia.}

The climate is continental, the winter is cold and the summer very hot. Kasalinsk has an annual range of almost $90^{\circ}$ Centig. $\left(+48^{\circ} \mathrm{C}\right.$. summer-maximum, $-40^{\circ} \mathrm{C}$. winterminimum) (Schwarz p. 576). The precipitation is slight.

The winter is not very long, as a rule there is frost, not of long duration, but hard. In 1886 Tashkent had 89 lrosty 
days, Petro Alexandrowsk 127 (Schwarz p. 561). January is the coldest month, and Ficrer gives as the absolute minima for 10 years, $-28^{0}{ }_{44}$ and $-28^{0}{ }_{1}$ C. for Petro Alexandrowsk and Tashkent respectively. On the other hand, the temperature may rise to $+20^{\circ} \mathrm{C}$. in January. - Snow is not rare, but it seldom lies long on the ground.

Spring comes quickly, commencing at the end of February, and it is comparatively warm; April is warmer than October. In May the average temperature is over $20^{\circ} \mathrm{C}$. July is the hottest month, with absolute maxima for 10 years, according to Ficker, $43^{\circ}{ }_{, 4}$ C. and $42^{\circ}{ }_{11}$ C. for Petro Alexandrowsk and Tashkent. In Merw $44^{\circ},{ }_{\star} \mathrm{C}$. has been recorded, and in Namangan (Ferghana) as much as $47^{\circ}{ }_{6} \mathrm{C}$. (Mushisetow). The atmosphere is clear and nightly radiation strong, so that the temperature varies greatly as can be seen from the maxima and minima given in Table 1 . The daily variations in temperature are also very great, but as the Russian meteorological stations do not record maximum temperatures, except the temperatures at $1 \mathrm{p}$. m., no definite figures can be given. At Tashkent in the years 1900-1902 the difference between the minima and the $1 \mathrm{p} . \mathrm{m}$. readings varied from 11,4 to 20,0 , but the maximum occurs later in the day than $1 \mathrm{p} . \mathrm{m}$. Radde (1899) records from the sand-desert a variation of temperature of $36^{\circ}$ in 24 hours, while Capus (p. 20) gives up to $40^{\circ}$, and ObRutshew (quoted by RADDE) records the following temperatures for the month of March in the sand-desert: At $6 \mathrm{a} . \mathrm{m}$., $3^{0} ; 9$ a. m., $20^{0} ; 1$ p. m., $28^{\circ}$ C.

At Tachta on the Murghab river near the northern border of Afghanistan, the following temperatures were observed on June $23^{\text {rd }}$ (RADDE 1899 p. 151):

6 a. m., in shade $25,{ }_{5}{ }_{5}$, in the sun $34^{\circ} \mathrm{C}$.

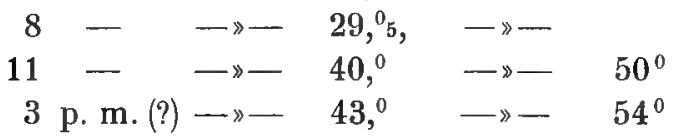

Schwarz (p. 559) gives the monthly and yearly amplitudes for a number of stations. 
The amount of cloud is greatest during the winter (December-January) and least in summer (August). Buchara has 180 bright days per annum; at Petro Alexandrowsk, for instance, the average number of bright days is 17 in June, 22 in July, 25 in August, 23 in September and 18 in October (FICKEl p. 554), and other places have about the same number. An overcast sky is rare during the summer; thus Petro Alexandrowsk has the low average of about 4 days during the five months June--October, and Tashkent about 8 days when the sky is overcast.

Calm days predominate, and from the records of KersNowskis (p. 108) I have calculated that at Petro Alexandrowsk, 27 per ct. of all the observations for the year (which are made 3 times daily) showed calm. During the summer months it was 29 per ct. - The prevailing winds come from the N. and N.E., they average 37 per ct. for the whole year and 41 per ct. for the summer months. Less frequently the winds blow from the E. and N.W., while winds from the S,S.E. and S.W. together total at Petro Alexandrowsk only $5 \mathrm{p} . \mathrm{ct}$. during the summer months. The prevailing $\mathbf{N}$. and $\mathbf{N}$. E. winds are moreover the strongest, yet only rarely do they attain any great strength; they are also the most constant, and blow especially during spring and summer being accompanied by bright weather, a cloudless sky and dry air. They are dry in themselves, and as they travel from colder to warmer zones they yield no precipitation, but cause evaporation (Mushketow).

The precipation is slight. In contrast to southern Russia which has summer rain, the precipitation maximum occurs here during the winter or the spring (HanN III p. 192). The winter snow must be of great importance to the vegetation, and as late as April in many places rain cannot be termed rare. July and August are exceedingly dry, in Merw it has not rained at all during these months for four years. When greater quantities of rain fall it is as a few heavy downpours, not continuous rain. The number of rainy days is therefore small, which is of great importance to the plants, because extreme conditions are the result. 
The relative humidity is given by Ficker, from a yearly average for all the stations, as 61 per ct. In Table 1 will be found the averages for each month at 3 different times of the day. It must be remembered, however, that these figures are taken on an oasis where the degree of saturation must be greater than in the desert. Olufsen records (1901 pp. 12-13) from various places (Merw, Buchara, Kona Urgentsh) relative humidities of 13-19 per ct.

On account of the heat and dryness in Transcaspia during summer it is natural that evaporation must be very great. According to Semenow (p. 128) evaporation is 3 times greater than precipitation in Tashkent and Samarkand, 4 times in Ferghana, 24 times in Nukus, and 270 times in Petro Alexandrowsk. Nukus and Petro Alexandrowsk lie south of the Aral Sea not far apart, and obviously local influences have to be reckoned with here.

The figures in Table 2 show the amount of evaporation and its relation to precipitation. For the daily evaporation per month we find amongst others a table in Mushketow p. 508 taken from Stelling, and another in Schwarz p. 572.

As a result of the evaporation being much greater than the precipitation, the country is becoming drier and drier. SchWarz (p. 578) proves that the Syr Darya, the Aral Sea and other lakes are continually decreasing. According to some calculations the Aral Sea sinks 7 metres, according to others 4,2 metres in the course of a century, and ScHWARz is of opinion that Turkestan is in process of being irretrievably ruined on account of scarcity of water. Buchara is already on the verge of ruin because Samarkand, which lies higher up the Serafshan river, uses all the water available.

Bonszczow is also of opinion that the drying up of Transcaspia is increasing, while BAER has come to the conclusion that there is now a condition of balance. As regards the Aral Sea, Berg points out (1908 p. 374), that the water-level is changing, and that at the present time it is rising after a minimum in 1880 .

Comments on Table 1. This table gives meteorological data from three stations: Tashkent (comparatively cold and 
moist), Petro Alexandrowsk which is situated near Chiwa south of the Aral Sea (drier and colder during winter, but warmer during summer), and Askhabad to the north of the

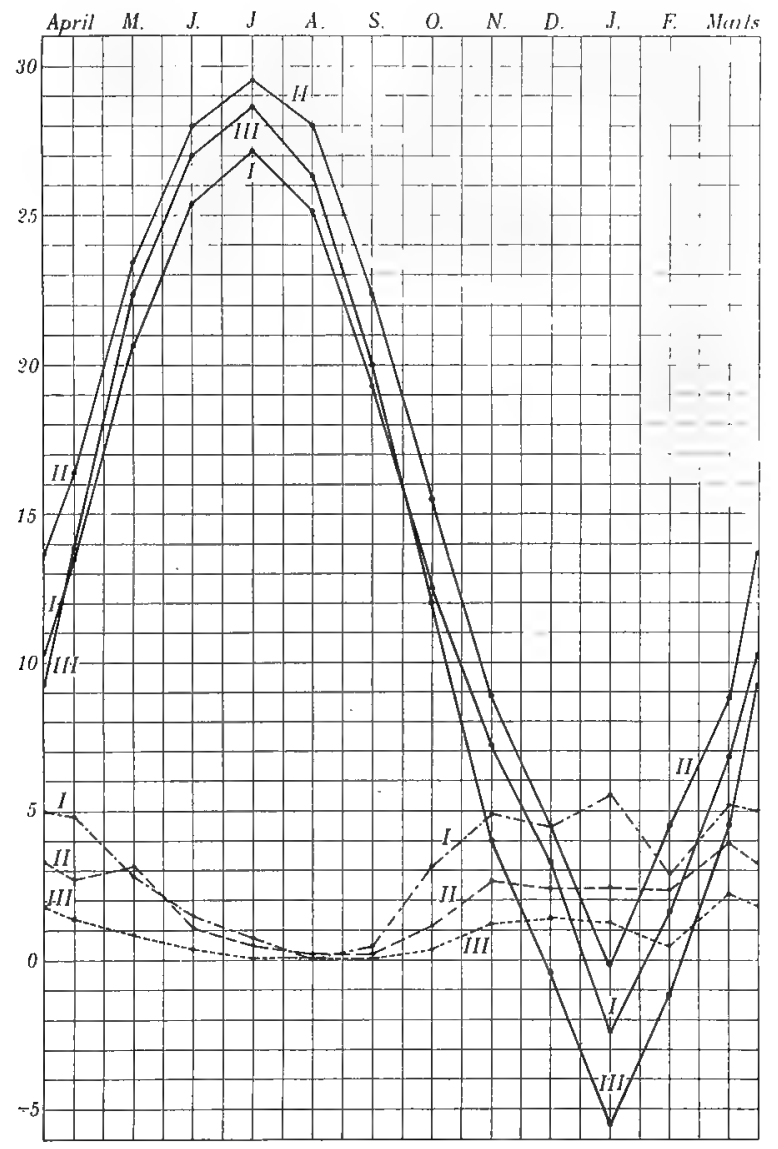

Fig. 1. Hydrothermals for three stations in Transcaspia, viz.: I. Tashkent, II Askhabad, III Petro Ålexandrowsk. The ordinary lines are temperaturecurves, and the figures to the left express degrees Centigrade. The dotted lines give the precipitation in centimetres. (Constructed after the method of RAUnKJere $(1905,1907)$.

mountains bordering Persia (very hot and dry). The temperature and precipitation of these stations are moreover marked out in curves in the manner indicated by RAUNKJ ER (fig. 1). 
The table is prepared from the annual rolumes (18971906) of "Annales de l'Observatoire physique central de St. Pétersbourg», especially from "Résumés mensuels et annuels». The observations were made every day at 7 a. $\mathrm{m} ., 1 \mathrm{p} . \mathrm{m}$. and $9 \mathrm{p.m}$. The maximum averages given are the mean of the highest readings at 1 p. m., and are therefore too low because that hour is not the hottest part of the day. The minimum averages on the contrary are the mean of real minima; they are not given for Petro Alexandrowsk.

The figures on the whole correspond with those given by Ficker for another decade.

Brackets round a figure indicate that it is not the mean of 10 years' observations, but only of $7-9$ years' on account of gaps in the series of observations.

Within a territory of the size of Transcaspia there are of course meteorological differences, the extent of which may be seen by reference to the great "Atlas climatologique», wher ethey are charted. We need only point out here that the area south of the Aral Sea has the least precipitation and that from this centre there is an increase on all sides. As defined by Köppen this area has a true rain-less climate, the rain-probability being under 0,20 . Petro-Alexandrowsk has 0,1 , Askhahad 0,33, Tashkent 0,36 .

Further details are unnecessary as I do not know the vegetative conditions intimately enough to be able to correlate the climatic differences with them.

The "light-climate» of Aralocaspia is characterized by the large number of cloudless days. Wiesner mentions (quoting from $\mathrm{H}_{\text {ANN }}$ ) that in the Kirghiz Steppe there are 170 cloudless days per annum. The foliage of the plants is here aphotometric, that is it has no fixed position in relation to the light; or it is only in the lowest degree photometric, having a fixed position to the light (WIESNER p. 62). This is in the main correct, yet plants occur which turn their leaves in accordance with the light, for example Glycyrrhiza and Smirnowia. 


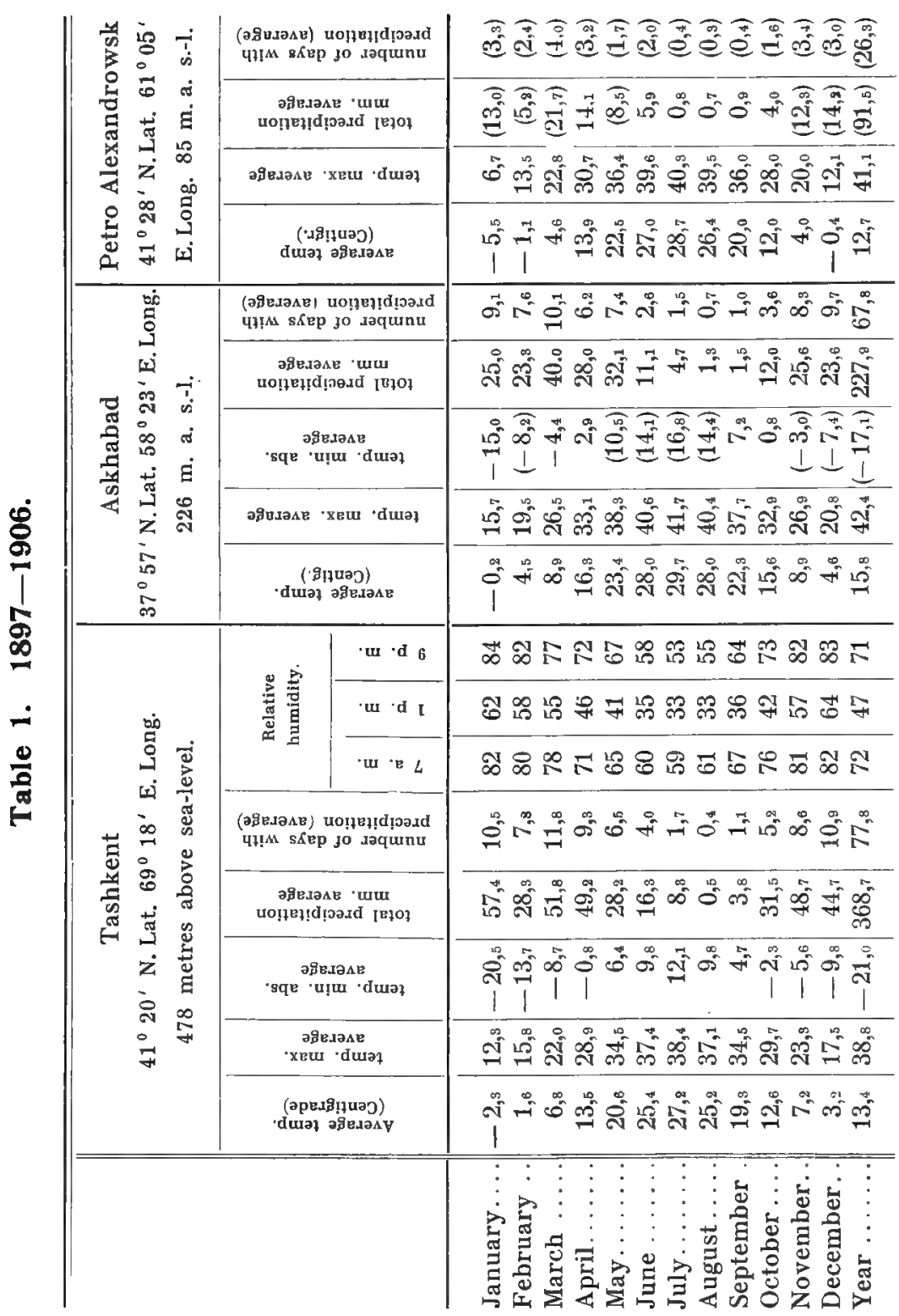


Table 2.

Amount of evaporation and precipitation for St. Petersburg and two stations in Transcaspia. After Britzke Table 8.

\begin{tabular}{|c|c|c|c|c|c|c|c|c|c|c|c|c|c|c|}
\hline & & 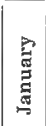 & 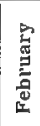 & 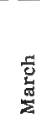 & 吾 & 焉 & $\stackrel{\Xi}{\Xi}$ & 宣 & 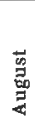 & $\begin{array}{l}\text { त् } \\
\text { है }\end{array}$ & $\begin{array}{l}\text { L } \\
\text { o. } \\
\text { : } \\
0\end{array}$ & 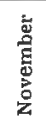 & 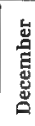 & 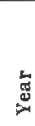 \\
\hline
\end{tabular}

St. Petersburg (average of 20 years' observations) \begin{tabular}{l|r|r|r|r|r|r|r|r|r|r|r|r|r} 
evaporation, mm. & 4 & 5 & 10 & 24 & 44 & 63 & 63 & 46 & 31 & 18 & 8 & 4 & 320 \\
precipitation, mm. & 22 & 22 & 23 & 23 & 42 & 47 & 66 & 66 & 50 & 43 & 36 & 31 & 470
\end{tabular}

Tashkent (average of 14 years' observations) \begin{tabular}{l||l|l|l|r|r|r|r|r|r|r|r|r|r} 
evaporation, mm. & 29 & 39 & 87 & 97 & 146 & 198 & 215 & 201 & 139 & 88 & 57 & 43 & 1339 \\
precipitation, mm. & 41 & 40 & 66 & 55 & 17 & 4 & 1 & 2 & 4 & 21 & 22 & 56 & 328
\end{tabular}

Sultan Bend S. E. of Merw (average of 2 years' observations) evaporation, mm. $\mid$\begin{tabular}{l|l|l|l|l|l|l|l|l|l|l|l|l|l|}
35 & 52 & 104 & 194 & 302 & 459 & 526 & 466 & 296 & 157 & 109 & 64 & 2764
\end{tabular}

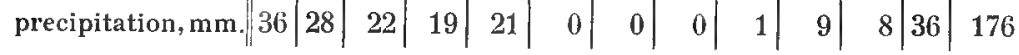

\section{SECTION II. THE VEGETATION OF THE TRANSCASPIAN LOWLANDS}

\section{CHAPTER 4}

\section{Earlier Literature.}

The botanical literature on the Transcaspian lowlands is already large. During the first half of Jast century, Russian naturalists began to examine this country which was up till then, at least as regards natural history, an unknown land, and since then numerous memoirs have been published. Since the Russian occupation of these vast areas, they have 
been examined by many naturalists; but the papers containing the results of the journeys are scattered throughout different periodicals, mostly Russian and often very difficult of access. More especially during the later decades when it has become a national feature to write in Russian, it is very hard for anyone in western Europe to study Russian literature. The publications on the botanical conditions of the Transcaspian lowlands are - so far as we can ascertain - mainly taxonomic, lists of plants and descriptions of new species. There now exists a large amount of systematic material which in recent years is gradually becoming arranged into consecutive floras, mainly through the works of Fedtschento.

Very few descriptions of the vegetation exist, still less any attempts at ecological treatment. What I have had access to will be dealt with in this account, and Russian authors, inaccessible to most people, will be reported in greater detail than those who have written in the languages of western Europe.

BASINER's journey through the Kirghiz steppe to Chiwa. This account dates from 1848. He travelled from Orenburg to Chiwa, and he gives many lists of plants as well as brief descriptions of the vegetation, and other botanical remarks. The greater part of the territory where he travelled does not belong to the areas dealt with in this work. BASINER describes the «steppe» between Orenburg and Usturt with its three regions: The grass region, the transitional region and the region of Chenopodiaceae of which the first is the most northern, the last the most southern region. The region of Chenopodiaceae is evidently closely related to the desert ot the south, such as we deal with later on. Frequently the soil is devoid of plants, yet in places a considerable number of plants were found, but these form «keine heitere Hülle, sondern höchstens ein dunkles Trauergewandt». The most common plants are: Salsola brachiata, clavifolia, crassa, Kali, Anabasis aphylla, Brachylepis salsa and Artemisia (Artemisia fragrans). The number of Chenopodiaceae increase towards the south and many individuals of a species were often found in masses together. 
The plateau of Usturt which lies between the Aral Sea and the Caspian is divided by BAsiner into four vegetationregions: the Clay-region, the Sand-region, the Marl-region and the Salt-region. The first named embraces the greater part of the plateau, is dry and bare with a scattered vegetation. During spring many annuals are in bloom especially Cruciferce and bulbous plants (Allium and Tulipa); during autumn hardly anything but scattered perennial Chenopodiaceae are found: Saxaul, Anabasis aphylla, Salsola glauca, Arbuscula, crassa, rigida, Brachylepis salsa and the polygonaceous Atraphaxis spinosa.

The Sand-region consists of scattered sand-hills (dunes) The vegetation is richer than on the clay, as the sand retains the moisture better. The most common plant is Pterococcus aphyllus (= Calligonum Pallasii), next comes Tamarix gallica, and of annuals we find recorded Salsola Kali, Horaninowia ulicina, Corispermum laxiflorum and Asperula Danilewskiana.

The substratum of the Marl-region is looser than clay, but more compact than the sand. It occurs especially in crevices between rocks and other similar places on the eastern slope of the plateau; the vegetation is comparatively rich, BASINER gives a long list of plants which are found during autumn. This contains some annuals (Cruciferae), and many herbaceous perennials, undershrubs and bushes such as: Peganum Harmala, Astragalus-species, Alhagi Camelorum, Tamarix, Artemisiae, Chenopodiaceae, Atraphaxis,

The vegetation of the Salt-region is chiefly found round the coast of the Aral Sea, both on marl and on moving sands. The most important plants are: Frankenia intermedia, Zygophyllum Fabago, Lycium ruthenicum, Saussurea crassifolia, Salsola ericoides, Schoberia (= Suoeda) microphylla, Halocnemum strobilaceum, Halostachys caspica, Atriplex laciniatus, and on sandy soil: Clematis orientalis, Mulgedium tataricum, $\mathrm{Cy}$ nanchum acutum, Phelipaea salsa.

BASINER also describes thickets on the river sides with tamarisks, willows and poplars, and a wood of Saxaul, which took three hours to traverse. The height of the trees was 15 to 20 feet and the diameter of the stems 8 inches or more. The year-rings were very narrow, 200-260 being 
counted. The wood is brittle, for which reason providence has not furnished this tree with leaves, for if leaves were present a slight gust of wind would break the stem.

The next account from the lowlands of Transcaspia is Alexander Lehmann's "Reise nach Buchara und Samarkand". In the years 1841-1842 Lenmans, in the capacity of naturalist, accompanied a Russian envoy to the Emir of Buchara, but he died shortly after his return to Russia. The very large collections of plants made by him were examined and described by AL. Bunge, and this book is still a standard work. Lehmann's notes on the journey were published in 1852, after revision by G. v. Helmersen. The account contains occasional remarks on the scenery of the country, and short lists of plants from different localities, but one feels that the material has not been revised by one who knows the country from personal observation; it lacks those comprehensive comments, which convey a general view to the mind of the reader and make of the work a connected whole.

The next work to be dealt with is Borszczow's Russian memoir: "Contribution to the Geography of Plants in the Aralo-Caspian countries" $\left.(1861)^{1}\right)$. This begins with a short topographical-geological survey of the country. In the introduction to the phytogeographical part of the work we find the following remarks:

"The flora of the Aralo-Caspian countries is only partly the flora of the steppes; to a great extent it is a desertflora, characterised by the prevalence of bushes and undershrubs with herbs growing below, or by the almost exclusive occurrence of the first-named. This is the first physiognomical feature of the region we are dealing with.

The second characteristic is the general poverty of the plant-covering. The vegetation develops with the greatest difficulty -- one might say reluctantly - on a soil containing an abundance of salts, which is continually scorched by the merciless rays of the sun and only rarely refreshed by a light rain. It does not cover the area uni-

1) Bonszczow's "Ueber die Natur des Aralo-Caspischen Flachlandes" (1860) contains an orographical description of the area. 
formly, but appears in oases, between which stretch large tracts of quite bare soil. Even in the north-western part which has a more favourable situation and climate, and where the flora is more steppe-like in character, we look in vain for the luxuriant growth of the herbaceous plant forms which are a characteristic of the steppes of southern Russia and southern Siberia. It is not found here. The immediate neighbourhood of the vast burning deserts which occupy almost three-fourths of the whole area, and the insufficiency of the precipitation (!) have too great an influence on the climate, moreover the soil itself possesses too few of the conditions which are necessary to produce a luxuriant vegetation. The herb-covered steppe, the only refuge for the nomad and his numberless cattle, is here only a dry Stipa Steppe whose vegetation forms hardly anywhere a thick carpet; only in the river-valleys (and frequently not even there) do we find a somewhat richer development.

Here, as throughout the whole of Aralo-Caspia, it is a few specially characteristic forms which prevail, they repeat themselves continually so that the country has a very monotonous appearance. Other species are only subordinate to these. Where the character of the soil changes, these predominant species sometimes change very quickly and give place to others which in turn prevail until the soil changes again. This monotony and this repetition of certain species over vast areas is the third characteristic of the vegetation of the Aralo-Caspian countries. It is no doubt a direct consequence of the uniformity of the climate, which again is mainly dependent on the slight vertical relief of the surface.

A fourth characteristic of the flora is the unfamiliar appearance of many of the plant-forms ${ }^{1}$ ). As soon as the Ural is crossed, a different zone of vegetation is entered upon, where the plants differ greatly from those living in the same latitude, but in areas with a different geographical location, a different relief and different soil. Even

1) Great poverty in Cryptogams is also a characteristic.

(B.'s remark.) 
the flora of the right bank of the I'ral between Uralsk and Orsk differs in many ways from the flora of the left bank. On the right bank we find for instance frequently: Arabis pendula, Adenophora liliifolia, Tilia parvifolia, Prunus Chamaecerasus, some Verbascum species, Urtica dioica and $U$. urens, Senecio vulgaris and many others, but they disappear totally on the left bank of the river and never appear again ${ }^{1}$ ). The unique character of the flora is still more strongly expressed in the heart of the country, south of 490 N. Lat. Plant-forms such as Saxaul (Haloxylon Ammodendron) Kara-Djusgjon (Calligonum-species), the unfamiliar poplars Populus diversifolia and $P$. pruinosa, KujanSujok (Ammodendron Sieversii, A. Karelini) and the species of Chenopodiaceae, Papilionaceae, Cruciferae \&c. are all unique in appearance and structure, and could only be developed under special conditions of climate and soil. In the Aralo-Caspian lands, the soil in particular has such a great influence on the vegetation that a change of soil - other conditions remaining the same - often alters the physiognomy totally and almost abruptly without any gradual transitions. This change is most evident in the moving sand deserts, where the depressions between the sandhills are mainly corered by salt-swamps or by a loose clayey bottom permeated with salts. The vegetation on the sand-hills is varied and highly characteristic, but its spe-

1) Borzszcow comments on this in more detail in another place ("Ueber die Natur d. Aralo-Casp. Flachlandes", p. 272, Anm.): on approaching the steppe, the tree-vegetation disappears, poplars, elms, limes, birches, willows, Prunus Chamaecerasus and P. Padus; instead of Salix fragilis and S. viminalis so common in the Ural we have here $S$. pallida and S. Wilhelmsiana and "sogar die, im Ganzen, dem Grassteppen-Gebiete angehörigen Sträucher: Caragana frutescens, Spiraea crenata u. hypericifolia und Amygdalus nana kommen südlich von Ural nur gruppenweise und selten vor" Stipa pennata is replaced by $S$. capillata and $S$. Lessingiana. A great many plants disappear altogether (Delphinium, Arabis, Trifolium, Fragaria, Scabiosa, Senecio, Urtica, Poa, Aira \&c.) The Ural is a line of demarcation between the grass and forest region on one side, and the "true steppe" on the other.

The change in the soil and vegetation south of Tshagan and the steppe-mountains was, however, previously pointed out by Pallas (1776, p. 310). 
cies suddenly disappear at the margins of the depressions and all that is left is a meagre flora, frequently reduced to two or three Chenopodiaceae, such as Brachylepis salsa, Anabasis aphylla, species which are uniformly distributed throughout the whole area.

These changes in the soil-conditions are mainly responsible for the variations in the general physiognomy of the vegetation. They also bring into prominence certain plant-forms which may be observed over considerable areas and which furnish the features characteristic of the areas or sub-floras into which the Aralo-Caspian countries may be divided.

There are five of these areas:

1) The Stipa-steppe

2) The Clay-deserts

3) The Salt-deserts

4) The Moving-sand-deserts

5) The river Serafshan."

The following is a summary of Borszczow's description of these areas.

1) The area of the Stipa Steppe is the most northern, and extends from its southern boundary at the Mugodshar mountains and the rivers Tshit-Irgis and Turgai, towards the $\mathrm{N}$. E. where it merges into the grass steppes of the southern part of the Tobolsk government. The Stipa Steppe thus lies outside of the area under consideration in this work. The surface of the steppe is almost everywhere undulating. Forests do not occur, but here and there are groves mainly consisting of poplars and willows. The most prevalent plant is Stipa capillata, then follows Festuca ovina. Besides these a number of species are recorded: Amygdalus nana, Spiraea-species, Ulmus campestris, Caragana frutescens, Poplars, Willows, Betula and Alnus, Ranunculaceae, Dianthus and Silene, Eryngium, Trinia, Compositae (Cirsium acaule, Jurinea, Saussurea, Echinops), also Tulipa, Iris, Allium and Carex. About 10 per ct. of the 
lotal species (551) are trees and shrubs; the proportion of biennials and perennials to annuals is $1: 0,31$.

For each area Bonszczow gives statistics which show for a number of families the proportion of species in the given area as compared with the whole country examined by him. After so many years of further research in these countries, his figures must be far from correct, but as they have a certain interest, the figures for a tew selected families are given. In the area of the Stipa Steppe were found:

57 per ct. of the Ranunculaceae of the whole area.

$\begin{array}{llll}47 & -»- & \text { Cruciferae } & -»- \\ 41,8 & -»- & \text { Papilionaceae } & -»- \\ 50,5 & -»- & \text { Compositae } & -»- \\ 28,7 & -»- & \text { Salsolaceae } & -»- \\ 74 & -»- & \text { Cyperacede } & -»- \\ 58,9 \quad-»- & \text { Gramineae } & -»-\end{array}$

The Stipa Steppe is rather monotonous in character and resembles in many ways the steppes of the adjacent western governments. It is by no means always a fertile grass-steppe, more often it is dry, clayey and poor, and the farther south one goes the more frequent do large bare patches of clay become.

Borszczow distinguishes three floras included in the Stipa Steppe: the grass-steppe, the stone-steppe (Mugodshar and its slopes) and the clay-stone-steppe. This last flora embraces, especially in its southern part, many species characteristic of the clay and salt deserts.

2) The area of the Clay Desert stretches, according to Bonszczow, between the Caspian Sea and the Aral Sea (Usturt), and again to the north and east of the Aral Sea. The surface is an undulating plain, generally of higher elevation than the soil of salt-deserts and moving-sands. The soil consists of pure compact clay and loose or compact clayey or sandy marls. Almost everywhere the soil is permeated with salts, and salt-swamps are not uncommon. The resemblance to the steppes of southern Russia seen in parts of the Stipa-steppe has disappeared here. The vegetation is 
characterized by few, but exceedingly characteristic plant forms, and a terrible monolony. - Of the plants (329 species) in this formation, $10,6:$ per ct. are shrubs. The proportion of perennials and biennials to annuals is $1: 0,7$.

Bonszczow's percentages for the families already named are as follows for the area of the clay-desert:

29,6 per ct. of Ranunculaceae of the whole area.

$\begin{array}{llll}40,9 & -»- & \text { Cruciferae } & -»- \\ 17,09 & -»- & \text { Papilionaceae } & -»- \\ 23 & -»- & \text { Compositae } & -»- \\ 49 & -»- & \text { Salsolaceae } & -»- \\ 26 & -»- & \text { Cyperaceae } & -»- \\ 23 & -»- & \text { Gramineae } & -»-\end{array}$

The most frequent species are Artemisia fragrans and A. monogyna; these alone cover large tracts and present a most melancholy picture. They are frequently accompanied by Salsola crassa, S. lanata, Brachylepis (Anabasis) salsa and Anabasis tatarica, sometimes with Saxaul (Haloxylon Ammodendron), and Ferula persica, Rheum caspicum and Calligonum Calliphysa.

"The occurrence of these (the three last-named species) is so closely correlated with the soils of this area that it is possible with the aid of only a few specimens to determine with great certainty the character and physiognomy of the sub-flora from which they are taken."

The plants mentioned are almost the only ones to be found in the clay-deserts after the second half of April when the sun becomes very powerful. In spring the flora is richer, during the flowering season of species of Alyssum, Megacarpaea, Tauscheria, Euclidium, Matthiola, Chorispora, Echinospermum, Onosma, Phelipaea, Allium (A. caspicum), Tulipa patens, and Rhinopetalum Karelini. These plants are the "spring decorations of the desert flora", but unfortunately they are too quickly lost again. A richer vegetation of roses with Spiraea and Elaeagnus oecurs in the deep ravines on the margin of the Usturt.

3) The area of the Salt-deserts stretches over a very 
large expanse at the north-east end of the Caspian Sea, but smaller stretches are found interspersed in other territories. The surface is a perfectly level plain covered with innumerable salt-lakes with here and there sand-hills. The soil is a compact clay often hard as stone, or loose marl with a mixture of chalk, permeated to a considerable depth with salts.

The vegetation is exceedingly poor and uniform. Out of 170 species, characteristic for the salt-deserts, 63 are Chenopodiaceae, 17 per ct. are trees or shrubs (a very high proportion); perennials and biennials are to annuals as $1: 1, \ldots$

In spite of uniformity, the physiognomy of the evergreen salt-swamps has a much less desolate appearance than the clay-deserts.

"Here (in the salt-deserts) the vegetation tries, as it were, to make up for uniformity by its characteristic forms and by constant freshness and unusual tints. Enormous salt-swamps, pale green during the spring, turn by degrees yellowish and finally light-yellow, as the burning heat comes on, and again during the early days of autumn the colours turn to pink, scarlet and purple. Simultaneously the young green of the new branches shows forth and the four colours blend in the most charming way. It is difficult to imagine the effect of such a picture especially at sunrise or sunset, and one must see it to realize its beauty."

The salt-deserts contain : -

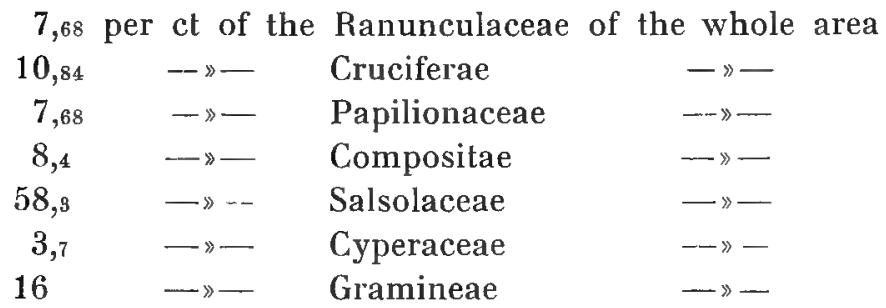

It will be seen that the Salsolaceae predominate here.

Borszczow gives as the most common amongst them: Ceratocarpus arenarius, Kalidium foliatum, K. arabicum, Halocnemum strobilaceum, Salicornia herbacea, Schoberia (Suaeda) 
baccifera, S. salsa, Salsola clavifolia, Ofaiston monandrum, Halimocnemis villosa, H. sclerosperma, H. glauca, Halogeton glomeratus, Anabasis aphylla, A. brachiata, Brachylepis (Anabasis) salsa, Halostachys caspica. Another important species is Zygophyllum Eichwaldii.

4. The area of the Moving-Sands.

This stretches mainly south-east and east from the Aral Sea. The vegetation is more luxuriant than in the other areas, and is at the same time more interesting and richer in rare and strange plant-forms. In spring it looks quite like a garden. The dunes are covered with bushes of Calligonum, Halimodendron, Saxaul, Tamarix, Salsola etc. Some of these are also present in other formations, but reach here their fullest development, "so that this territory may justly be termed the forest of the desert-flora". ${ }^{1}$ )

Of the 501 species of Phanerogams characteristic for the sand-flora, 16,16 per ct, are trees and shrubs. The proportion of perennials and biennials to annuals is as $1: 0,75$. 235 species belong exclusively to the dunes. The sand-flora includes :

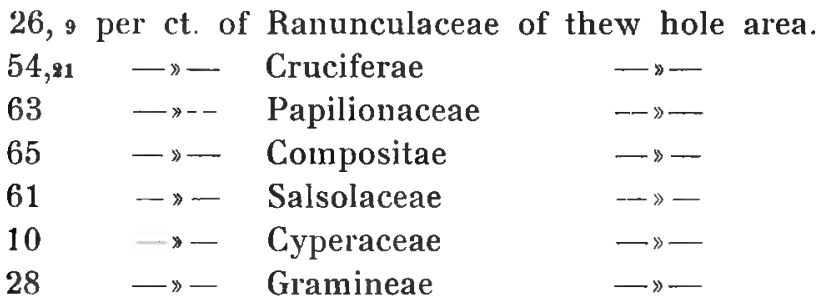

In addition to Cruciferae and Papilionaceae, Borragineae and Polygonaceae are also plentiful. Bonszczow mentions amongst the Cruciferae: Dontostemon (several species) Sireptoloma, Spirorhynchus, Pachypterygium, Cithareloma, Lachno-

1) This simile has justly been contradicted by KoRSChINSKY and TANFILJEW. Yet LIPSKY (1911) is of the opinion that some large tracts of Saxaul - but only of this - may rightly be named forests, the trees being big and thick and giving a considerable amount of ground-litter 
loma, Chartoloma and Octoceras; the Papilionaceae include Ammodendron, Halimodendron, Ammothamnus, Eremosparton, Alhagi and Astragalus. As representatives of other families we may mention: Heliotropium, Echinospermum, Calligonum (17 species) various Umbelliferae (Dorema, Ferula etc.), and Compositae (Artemisia, Echinops, Cousinia, Microlonchus, Scorzonera, Streptorhamphus, etc.). The Salsolaceae are represented by much the same species as in the salt-deserts, but they are more luxuriantly developed; noteworthy are Alexandra Lehmanni, Caroxylon (Salsol(r) hispidulum, C. subaphyllum, Eurotia Eversmanniana. Smaller families are also represented by a number of species: Zygophyllaceae, Rutaceae, Tamaricaceae, Gnetaceae (Ephedra), and of Monocotytedons the following may be named: Biarum, Tulipa, Merendera, Gagea, Heleocharis.

4) The area of the Serafshan River.

Lying as this does in the mountainous regions along the upper courses of the river, it is outside of our area and need not be considered.

Following on the introductory description just summarised, Borszczow then deals with the families of plants with respect to the distribution of genera and species. This analysis occupies the greater part of his work and leads him to the following general conclusions:

"1. The majority of the commoner plants of Central Russia with a distribution west of the Caspian Sea extending to Trans-Caucasia, have as their southern limit of distribution east of the Caspian Sea in Aralo-Caspia, the parallel of $51^{1 / 2}{ }^{0} \mathrm{~N}$. lat.

2. When these forms occur farther east in Siberia, the boundary limiting their area of uninterrupted distribution lies outside of Aralo-Caspia and always north of $51^{1 / 2}{ }^{0}$ N. lat.

3. Most of the typical steppe-plants met with in southern Russia and distributed towards the west from the Caspian to the foot of the Caucasus, attain their southern limit in Aralo-Caspia at the parallel of $49^{\circ} \mathrm{N}$. lat., and their eastern boundary at the meridian of the Mugodshar 
range $\left(77^{\circ}\right.$ E. long., Ferro, ab. $60^{\circ}$ E. long., Greenw.) thus they do not overstep that part of the area of Stipa which we have termed the Grass-steppe. If these plants occur farther east, their limit of uninterrupted distribution is a line generally extending towards the north along the western slopes of the Mudgodshar Mts.; from the north end $\left(50^{1 / 2}{ }^{0} \mathrm{~N}\right.$. lat.) of these the line strikes eastwards round the basin in which the middle and lower courses of the rivers Irgis, Ulkojak and Turgai are situated. They may of course be met with as isolated outposts south of this latitude, but never farther south than $49^{\circ} \mathrm{N}$. lat.

4. The more southern plant-forms, characteristic both for Persia and Aralo-Caspia. do not occur in our flora of the present time further north than $47^{\circ} \mathrm{N}$. lat.

5. The more eastern forms, met with in Altaian Siberia and Dsungaria, are rarely met with further west than $78^{\circ}$ E. long. F. (ab. $60^{\circ}$ W. Greenw.)

6. In the case of a great many south-eastern forms, the lower course of the Syr-Daria $\left(45^{0}-46^{0}\right.$ lat.) is the northern boundary, and the meridian of the eastern shore of the Aral Sea $\left(70^{\circ}\right.$ E. long. F., ab. $62^{\circ}$ Greenw.) forms the western boundary.

7. The areas east of the Aral sea must be considered as the centre of distribution for tree-like forms of the families of the Salsolaceae, Polygonaceae (Calligoneae) and Papilionaceae.

8. The flora of the Aralo-Caspian countries as known to us at the present time is relatively new in origin, and most of its plant-forms have probably distributed themselves over these parts of Asia within very recent times; presumably they came mainly from the east and south, to a less degree from west and north, so that from these directions they have not penetrated so far. This flora is the gathering ground for forms occurring in the steppes of South Russia, the Altaian Siberia and Persia. The original plant-forms indigenous to the area are evidently limited to: Salsolaceae, the tree-like Polygonaceae, Nitrariaceae, Zygophyllaceae and some species of Tamaricaceae, Papilionaceae and Cruciferae. 
9. When we take into consideration how the sheets of water and the river-systems are drying up ${ }^{1}$ ) while the dryness of the climate increases, it may almost be regarded as certain that the western and northern forms will ere long cease to reproduce themselves successfully in the Aralo-Caspian countries, and that forms already found there will begin to die out. On the other hand, it is beyond doubt that the southern and south-eastern desert-forms will continue to extend their zone towards the north and the west as a result of the environment. Saxaul, Elaeagnus hortensis and some others are at present migrating towards the north, whereas species such as Populus nigra and $P$. alba are disappearing from the southern latitudes where they occurred; this proves, that this period is already drawing near."

Bonszczow's memoir ends with some brief notes on the Cryptogams which, on the whole, are not specially important. Parmelia esculenta occurs sporadically in the deserts along with a few Lycoperdaceae.

In spite of its antiquity, Borszczow's work has been dealt with at considerable length because, on the whole, it conveys an interesting picture of the Aralo-Caspian countries. The relation of the flora to that of the surrounding areas is especially well defined, hence I have included the Stipasteppe, which otherwise does not come within the scope of this work. As far as I know, Borszczow's work is the only one that treats the flora of Aralo-Caspia from that point of view, but it may be that other important works have been overlooked on account of the inaccessibility of Russian literature.

The next work known to me in this connection is: A. A. Antonow: "On the Plant-formations of the Transcaspian territory") 1892.

l) According to BAER (1855), the phase of drying up is now past and a condition of stability has long ago set in. Comp. Schwarz and Berg, above page 14 .

") "Territory" is here given as the translation for "oblast". In Borszczow, "area" is given; this author uses it as corresponding to AnTonow's "formation." ANTONow himself uses the word "formation." 
Antonow travelled in these parts from April $18^{\text {th }}$ to June $27^{\text {th }}$ in 1889 , so that, as he states, he has not seen the flowering season of early spring, nor the late bloom of perennial plants.

AnTONow has six formations:

1. The flora of the Clay(or loess) Desert-plains.

2. The flora of the Riverside Thickets.

3. The Loess-steppe.

4. The Sand-desert.

5. The Promontory or Stone-steppe.

6. The Mountain or Rock-flora.

1. The formation of the Clay-Deserts is the most prevalent and has the greatest extension of all. The soil has a level surface and is formed by loess which is soft and greasy in its crude form, and hard as stone when dry. When very dry it cracks into $4-5$-angled polygons and the surface peels off. This soil may occur as the subsoil for other formations.

The flora is poor and monotonous, this formation being the domain of the Chenopodiaceae. Saxaul (Haloxylon Ammodendron) is the most important of these, it is here a low, twisted bush, no higher than an Arshin (about 0,7 metre); Salsola, Suaeda and Halimocnemis are also mentioned. The plants stand far apart from each other.---Where the moistureconditions are more favourable, the plants are more abundant and stronger, for instance near water-holes or saline places or on the more retentive sands of the dunes.

The saline places ("Takyr" and "Ssor") are mentioned as a sub-formation, but no details are given by which they can be differentiated.

2. The Riverside Thickets. Along the rivers on the narrow strips of land which are continually moist, Tamarix, Poplars (Populus euphratica, pruinosa), Willows, Lycium turcomanicum, Phragmites, etc. grow, often accompanied by the creepers Cynanchum acutum and Apocynum sibiricum (=A. venetum). They form a thick and often impenetrable living fence along the banks of the river, - a luxuriant vegetation, the poplars 
sometimes reaching the height of 5 Sashen (about $10^{1 / 2}$ metres) with a stem diameter of half an Arshin (about 0,35 metre). The poplars often grow along with reeds on low islands, which are covered at high water. The tamarisks grow smaller a few fathoms away from the river and become mixed with salsolaceous plants which enjoy the moisture, but even at a distance of two to three Versts (about $1 \mathrm{kilom}$.) into the desert stunted tamarisks may still be seen.

The vegetation of the river sides contains no flora of herbaceous plants and in this respect it differs from the alluvial forests in Russia, where Populus nigra takes the place of $P$. euphratica. AnTonow is, however, of opinion that the term forest should not be used for this formation, because it only appears in strips along the rivers and has so to speak only one dimension. In my opinion this remark is not quite correct, for in some places at least the vegetation in question has a considerable width, for instance in a deserted river-bed where the conditions of moisture are good.

Where a river bends sharply or has changed its bed, "Starizi" are often formed, enclosed backwaters where bushes and rushes grow, and "other herbaceous forms" occur around the stagnant water. In this connection, large "swamp-lakes", are also mentioned which are frequently formed in the plains by the snow-water in spring. Round these grow salsolaceous plants, but the occurrence of reeds and Tamarix makes it reasonable to include these places as riverside thickets. -Such thickets are often extensive, the haunts of wild boars and numerous birds, but as a rule uninhabited by man, hence Antonow calls them "biological oases."

3. The formation of the Loess-steppe is found on the same type of soil as the clay-desert, but with more abundant moisture; it occurs most frequently at the foot of mountains. It is rich both as regards species and individuals. As a type of vegetation it corresponds to the steppes of Southern Russia, but differs in its floristic composition. (Yet Antonow tells us later that no carpet of vegetation is formed, which is an important difference between this and the Russian steppe). As in southern Russia, Caragana and Prunus grow near streams, so here Tamarix is found, and in both countries tall herb- 
aceous perennials rise above the lower, brightly coloured ground-vegetation. The following herbaceous perennials are given for the asiatic steppe: Eremurus, Eremoslachys, Astragalus, Cousinia, Centaurea and several Umbelliferae.

4. The Sand-desert occupying about half the area of Transcaspia is the most recent geological formation. Its flora is very rich, and during the best season, April and May, it looks like a luxuriant garden. The plants include shrubs also annual and perennial herbs, but the shrubs are the most characteristic. This rich and extensive "flora or formation" has more definite limits than the others, its plants are dependent on the sand and do not migrate to other soils. The plants of the loess-deserts and the riverside thickets may intermingle or pass out on to the sand, but sand-plants are never found on loess soil. Saxaul grows both on loess and sand, nay thrives even better on the latter especially on "Ssor" covered by sand, but bushes like Calligonum or Ammodendron we look for in vain on the clay plain.

Antonow mentions as the most typical sand-bushes: Calligonum, Ephedra, Ammodendron, Eremosparton, Salsola Arbuscula, Astragalus dendroides, Haloxylon Ammodendron. These bushes attain a heigth of $1^{1 / 2}-3$ Arshin (about $1-2,10$ metres), sometimes under specially favourable conditions they may be 2 Sashen high (about 4, 2 metres). The stems are short and bent, with a low and richly branched crown. The leafage is very poor. The root-system in several of them is strongly developed. In Saxaul and Calligonum, radical branches may be seen on the surface between the dunes giving rise to new shoots and creeping sometimes for a distance of 5-7 Sashen (about 10,5-14,7 metres), so that these bushes play an important part in binding the sand. Still more important in this way are: Aristida pungens $(0,7-1$ metre high) which grows as a rule on the tops of the dunes, and Carex physodes which frequents more sheltered places among the dunes, and there weaves the sand together with its tangled roots. These two he calls the "conqueror and regent" of the sand-desert.

The following are given as representatives of the remain. ing herbaceous vegetation: Delphinium camptocarpum, Hypecoum pendulum, Roemeria refracta, Malcolmia africana, Spiro- 
rhynchus sabulosus, Astragalus sp., Erodium oxyrrhynchum, Alhagi camelorum, Senecio coronopifolius, less frequent are Dorema Ammoniacum, Sphaerophysa sp., Rheum sp.

5. The Promontory-or Stone-steppe is found on hard conglomerate soil at the foot of mountains, between these and the loess-steppe. It is an Artemisia-steppe, A. nutans being the principal plant. Amongst other species found are: Stipa orientalis, Papaver pavoninum, Cruciferae, Caryophyllaceae, Astragalus, Umbelliferae (Zosimia, Ferula), Compositae (Centaurea ovina, pulchella, Balsamita, solstitialis, Cousinia turcomanica, dichotoma, lyrata, Achillea santolina), Labiatae, Liliaceae, grasses and others. Ulmus nuda and occasionally the shrub Zygophyllum eurypterum occur by the streams.

6. The mountain-flora does not come within the scope of this review.

Next to be considered is the work of S. Korshinskx: "Sketches of the Vegetation of Turkestan" (1896), the first section of which deals with Transcaspia.

The "normal type" of sand-desert, the most extensive and continuous, is Konshinsky considers, "flat or undulating areas of sand" consisting of loose but not drifting sand, and covered by a meagre, yet comparatively rich and rather varied vegetation. Its most characteristic feature is that it consists chiefly of ligneous species: Haloxylon Ammodendron, Salsola Arbuscula, Calligonum, Ephedra, Ammodendron Karelini, Eremosparton, Astragalus Ammodendron etc. In the spring many herbaceous plants also occur, most of them growing isolated and not forming a carpet. A few species like Carex physodes and Capsella elliptica, are sometimes so luxuriant and dense that a green sward or something approaching one is formed. In the autumn the herbs have disappeared, and one finds then perennial species of Salsola, little bushes covered with handsome, multicoloured fruits.

The sandy parts are not so bare as one might imagine, Korshinsin says, so that there is really no reason why they should be called deserts. In spring, at least, the soil holds water at a few centimetres depth, and he adds: "I am of opinion that the sharply defined xerophytic character of the vegetation is not so much a consequence of the dryness of 
the soil but results rather from the dryness of the atmosphere, especially the strongly heated lower layers of the air, combined with the direct effect of the sun's rays, and the reflection of these from the hot bare yellowish-grey sandy soil."

Korshinsky regards the vegetation of ligneous plants described above as specially characteristic for the sand-desert, and he is also of opinion that this is the original vegetation which formerly covered the whole area of sand. The change from fixed to moving sands is, he thinks, due mainly, perhaps exclusively, to the action of man. As soon as roads and inhabited places are left behind, we find the sands more level and covered with the trees and shrubs just named. The nomads are mainly responsible for the extermination of trees and bushes, as they cut them down for firewood and their cattle eat and tread down the vegetation. As it is now we find perfectly lifeless areas, occupied by the high, crescentshaped "Barchans" devoid of plants. The transition to this is seen in the stage where most of the herbaceous plants have disappeared, and isolated trees and bushes occur with Aristida pennata and $A$. pungens still holding their ground.

Even in the barren desert, some vegetation may still be found in places where water from melting snows or river floods has collected in the hollows and deposited finer particles of earth which bind the sand together. In addition to numerous typical sand-plants, many of the more showy herbs grow here such as Ceratocephalus falcatus, Euclidium syriacum, Umbelliferae, Koelpinia linearis and many others; KonSHINSKY (p. 7) gives.a long list of them.

A further step in this direction in seen in the "Takyr", flats or depressions covered by water after rain. The water evaporates rapidly leaving a greasy soil, which when dry becomes very hard and cracks, salts frequently crystallising out. "Takyr" are almost always devoid of plants.

At the foot of Kopet-Dagh lies a narrow strip of cultivated land which towards the north is bordered by the desert. It is watered by streams coming from the mountains, but they are few in number and carry little water, so that large patches are left uncultivated among the fields In these uncultivated parts the desert plants are mixed with weeds of 
cultivation and with species originating from the neighbouring mountains. Noteworthy amongst the desert species are: Alhagi Camelorum, Salsolaceae, Zygophyllum and Peganum Harmala; the mountain plants are represented by Leontice Leontopodium, Glaucium luteum and Carex stenophylla, while the plants which frequent the neighbourbood of cultivated land are mainly Cruciferae and Papaveraceae (Roemeria); and often Hordeum murinum, Spinacia tetrandra, Arnebia cornuta, etc.

From the south-eastern part of Transcaspia, on the borders of Afghanistan, Korshinsky describes the vegetation at the foot of the Paropamisus chain. Here the landscape is undulating ("Badchis") with a sandy, but rarely a loose surface. The lower, more gently sloping parts of the "Badchis" have a vegetation which Korshinsky calls "sand-steppe". It consists "exclusively of herbaceous plants or undershrubs which, according to the relief of the locality or to variations in dryness of the soil, stand more or less scattered, but always singly so that they do not form a green sward." This picture recalls the steppes on the black-soils in the south of Russia. Just as Stipa pennata is there, so Stipa barbata is here in Asia the characteristic plant. Moreover there are several species of Convolvulus, Onobrychis, Ranunculaceae, Acanthophyllum, Aegilops, etc., and in the most southern part Dorema and Ferula.

The higher parts of the "Badchis" have a different vegetation to some extent characterised by other plants, such as Amygdalus horrida and Pistacia vera. This vegetation cannot be regarded as belonging to the lowlands, and so need not to be further detailed.

Korshinsky also gives a short description of the river sides with their thickets of Phragmites and poplars, especially $P$. euphratica. The irrigation of the cultivated land is also noted, and the plants cultivated there. His interesting work will be referred to again later.

RADDE's memoir: "Transkaspien und Nord-Chorassan" (1899) also contains many valuable statements about the vegetation.

He describes the hoof-shaped "Barchans" devoid of vegetation so that the landscape looks like a stormy but frozen 
sea, and the more rounded sand-hills ("Hügelsand") "like a smooth sea with a swell on". On the crests grow Halimodendron, Ammodendron, Saxaul and Tamarisks, while the hollows between them are covered by Capsella elliptica. The "sand-steppe" he likens to an almost calm sea which in spring bears a rich bloom of Capsella elliptica, Rheum caspicum, Calligonum, Atraphaxis, Lycium, Zygophyllum, Nitraria, Poa bulbosa, Bromus tectorum, Avena sterilis, Hordeum murinum, Stipa barbata. - RADDE also describes the sand mounds in the north-western parts of the territory; here in the valleys and on the slopes of the mounds, Saxaul attains its greatest development, while Ammodendron Sieversii prefers the loose soil of the crests.

The leafless desert shrubs occur almost exclusively where the sand is in motion; on old-established sand-hills we find for instance Prosopis Stephaniana, Heliotropium dasycarpum, Delphinium camptocarpum, species of Artemisia and Cousinia. - Only plants with tubers or deep running roots keep green long, the rest are quickly scorched.

RADDE's opinion is that the relatively luxuriant "sandsteppe" is the last stage, and that the moving sand will, if left to itself, gradually become covered with vegetation and then the country will in time become level.

RADDE's long account of his travels contains many other descriptive notes on vegetation, but it is unnecessary to enter into further detail here as the work is easily accessible and other references will be made to it later.

The description of Asiatic Russia by M. P DE Semenov (1900) also gives the more important features of the vegetation of Turkestan. He describes the trees of the sand-deserts, Haloxylon, Salsola, Calligonum etc. ("des arbres sans ombre, sans fraîcheur et sans vie") and records their importance in binding the sand. There is also an account of the vegetation of the clay-deserts of Artemisia, Salsolaceae, Zygophyllum and large Umbelliferae with their short-lived flowering period in spring, of the chenopodiaceous vegetation of the "salt-steppe" with its seasonal changes of colour and the dense thickets of poplars and reeds on the river-banks. The work also contains a number of geological, meleorological, and other 
observations. His classification of the sand-deserts will be referred to later.

The Petersburg Forestry Journal (1901) contains an important article by W. PalezkiJ on "Sand-binding on the MidAsiatic Railroad", and a later contribution has appeared in the Russian Forestry Journal (1908 nos. 31 and 32). The author has for many years superintended the operations for the protection of the Transcaspian railroad against sand-drift, and in $1899 \mathrm{I}$ had the pleasure of visiting parts of this undertaking under his able guidance.

The paper begins with description of the features of the different landscapes and the dune-formations, the dangers arising from sand, and the different ways in which the drift may block the railroad.

The most effective means of settling the sand-drift is to encourage vegetation; artificial means such as the planting of green turf and reeds are also resorted to. Trees are planted extensively along the railroad in belts 425 to 530 metres wide. Later on these spread naturally and have in some places reached a width of $2-3$ kilometres.

The natural conditions of the sand-deserts are extraordinary, he says. It does not rain from May till November, and the precipitation during winter and spring is insignificant. Ground-water containing bitter-salt, moving sands and the broiling heat of summer are other impediments to a luxuriant vegetation. In combating the sand it is therefore necessary to select local plants acclimatised to the conditions, and sufficiently aggressive to establish themselves. Experiments with introduced plants are, however, also made. The principal species used for planting are: Saxaul (Haloxylon Ammodendron), Salsola Arbuscula, Ammodendron Conollyi, Eremosparton aphyllum, Salsola subaphylla, Smirnowia turkestana, Astragalus paucijugus and A. Ammodendron, Aristida pennata, Carex physodes and various species of Calligonum. Short notes on their properties are given which we shall refer to later on.

Nurseries have been established in which stocks are raised for transplanting. As the desert plants often have very long roots which would be damaged by transplanting, the nursery 
at Farab is located in a place where the ground-water is only about 1 metre down, and $0,7 \mathrm{~m}$. during summer when the water is bigh in the Amu Darya. The roots on an average do not exceed 0,7 metre (1 Arshin) in this place. The conditions of precipitation and heat render it advisable to sow in the autumn, and before sowing the "seeds" are placed 10 or 15 days in moist sand, then into the soil loosened to a depth of about 30 centimetres. If Calligonum is to be sown in spring, the fruits must be kept over winter in moist sand, and the seed-beds are covered with straw as the seedlings are injured by late frosts. - After sowing all that is necessary is to weed the beds and to break up any salt-crusts which may appear, or to strew the soil with clean sand, which prevents the formation of salt-crusts. No watering is done except during abnormally dry seasons, since watering is generally harmful. The seedlings are thinned out, and in the autumn when a year old, they have grown to a height of from 0,35 to 1,4 metres $(1 / 2-2$ Arshin) (The author does not mention which species). The seedlings vary considerably, and this PalezkrJ considers to be due to differences in the salinity of the soil which interferes with growth. Development is also dependent on the depth to which the soil is loosened, and where this depth is great the plants may attain a height of 2 metres. The distance between the seedlings is also important, greater space giving larger plants.

The separation of the seedlings takes place in the autumn - except Saxaul which is very susceptible to frost, and from January to March the transplanting takes place. The seedlings are planted in rows at right angles to the prevailing direction of the wind, and it is highly important to select the right species for the different places. Thus low places with ground-water at a depth of $1-1,5$ metres are more suitable for Tamarisks, and where the subsoil is clayey Salsola Arbuscula thrives well. A subsoil consisting of lime and clay is specially favourable to Saxaul, while on pure shifting sand Ammodendron and Aristida and to some extent Calligonum grow readily. The success of the planting is dependent among other things upon the winter precipitation. During the first year, the plants are protected, and if the 
sand has been carried away, the roots are covered in with sand over which a layer of clay is spread. On an average about half the plants are successful, but the gaps are filled up by a second planting.

It is of the greatest importance for the natural seeding of trees and bushes that many herbaceous plants should grow on the sand; if these are absent, then many seeds of Aristida pennata and Alhagi Camelorum are sown. The herbaceous plants retain the fruits of the trees and protect the seedlings during their growth.

We have here only referred to those parts of PaLEziris's work which deal with the vegetation.

G. J. TANFILJEw in the second Russian edition of WarMiNG's "Plantesamfund" (Oecology of Plants) (translated by Genkel, St. Petersburg 1903) gives a survey of the vegetation of Russia. The chapter dealing with deserts is of special interest to us. Desert and Steppe are closely related in the following respects: both are at the present time devoid of trees, they are not leached by running water and the soil is rich in dissolved salts, especially carbonates but also sulphates and chlorides.

In the steppe, however, carbonate of lime is dominant, and the more soluble salts do not attain the same concentration as in the desert. The steppe-vegetation is therefore richer, forming a more or less thick carpet all the year round, and the decomposing vegetable matter gives a dark colour to the upper layers of the soil (for instance in the Tjernosem). In the deserts the carpet of vegetation is either absent altogether or is present only in early spring; during summer and autumn the earth is bare or only sparsely covered with woody stems or dead shoots. No green-sward is present and no dark humus is formed, but dissolved salts are abundant and often crystallize out on the surface.

The Semi-Desert (Loess-desert) is related to both steppe and desert. It resembles the desert in that it lacks the dark surface-layer of humus and the perennial sward of plants, while it has the high salinity of the loess. On the other hand, the luxuriant spring-vegetation is like the steppe, the loess of which is identical with that of the semi-desert. 
TANFLIEW gives a short description of the different parts of the Russian desert-territory which almost completely encircles the Caspian Sea.

1. The Calmuck Steppe between the rivers Manitsh and Volga and the Jergeni Mountains. The soil is here mainly clayey, and sparsely covered with species of Artemisia, Achillea, Alyssum minimum, Lepidium perfoliatum, Triticum, Poa bulbosa, Ceratocarpus, Astragalus, Alhagi, Zygophyllum, Anabasis etc. In sandy tracts the plants include Elymus sabulosus, Calamagrostis Epigejos, Euphorbia Gerardiana, Agriophyllum and Calligonum Pallasii; in salt-swamps are Tamarix and Salsolaceae.

2. The Kirghiz Steppe (Inner Horde) between the Volga and the Ural. The soil is saline clay with here and there moving-sands. The northern parts are the most fertile and include depressions with Tjernosem and true steppe-plants; here for instance are seen Stipa capillata and Lessingiana, Koeleria cristata, Silene viscosa and Otites, Phlomis tuberosa and pungens. etc., while the ordinary chenopodiaceous vegetation may be found on the neighbouring saline clay soil. Farther south the vegetation is poorer and in the sandy areas Pulsatilla, Tribulus, Cytisus biflorus, Astragalus, Amygdalus nana, Thymus odoratissimus, etc., are replaced by Elymus sabulosus, Stipa, Poa bulbosa, Carex stenophylla and physodes. Some of the latter are also found on the more northern sand areas, but are reported to be less prominent there. On the clay areas species of Artemisia are dominant. Low bills of gypsum have a characteristic vegetation (Matthiola tatarica, Eremostachys tuberosa, Fritillaria gibbosa, etc.).

3. East of the Ural river, TANFILJEw gives as the approximate northern limit of the desert, a line from Uralsk through Ulu Uil, the southern end of the Mugodshar mountains, the town of Irgis (Ft. Uralsk) to the southern spurs of the Ulutau mountains. North of this line lies the Stipasteppe, which in TanfILJEw's phytogeographical map of the Russian empire is also included in the desert. South of the Stipa steppes there is a salt clay-desert which occupies the peninsula of Mangishlak, the Usturt plateau and the area 
between the lower course of Syr Darya, the river Tshu, the northern shore of Lake Balchash and the upper Irtish.

The Stipa-steppe and the Clay-desert have already been referred to in our summary of Bonszczow's memoir which is also followed by TanfILJEw.

4. The Sand-Deserts in Transcaspia are described as by Borszczow and KorshinsKy.

In TanfiLdews treatise: "Die südrussischen Steppen" (1906), the difference between desert and steppe is again emphasized.

The Russian memoir by A. Rodsewitch: "The Tree-Vegetation of Transcaspia" (1896), is known to me only through a summary by LIPSKY in "Contributions from the Botanical Garden in Tiflis", 1902.

Of about 500 species found in Transcaspia, nearly half belong to the desert-flora; of these 17 per ct. are trees and 57 per ct. perennials. The characteristics of the desert-plants are: a strongly developed root-system, sclerenchyma in the stems, the radical branches encased in a siliceous coat, and the leaves poorly developed. The most important sand-plants are: Haloxylon Ammodendron, Tamarix gallica(?), Alhagi camelorum, Aeluropus repens, Salsola subaphylla, Populus diversifolia (euphratica), Ephedra, Eremosparton aphyllum, Aristida pungens var. pennata, Ammodendron Karelini, Calligonum and Salsola Arbuscula.

So far as I know these are all the available memoirs which deal with the vegetation of the Transcaspian lowlands. If all have not been included, I hope that nothing of great importance is left out. Descriptions in general works on plant-geography have been omitted since they must necessarily be compiled from the original works.

CHAPTER 5.

\section{Classification of Formations.}

On a lovely sunny day in April 1898 the expedition saw the brown mountains of Asia rising above the Caspian Sea. The mounlains near Krasnowodsk on the eastern shore of 
the Caspian are not beautiful, but low, round and aridlooking, they appear, as if scorched by the intense sunshine. No green was to be seen anywhere. It was delightful to get ashore and to glean our first impressions of nature in Asia. Plants were there on the mountains, although rather scattered; Gagea, Tetradiclis, Arnebia are here with many others, these are representative of three important forms of desert life: Geophytes, Halophytes and Annual Spring-Plants. There is scarcely time to observe more as the train soon starts eastwards and we bid the sea farewell for a long time to come. We pass through and across brown stony hills and flats with scattered bluish grey or green tufts of plants, foothigh Umbellifers and low leafless bushes. Then the sun sets. Next morning brings the finest sight we ever saw, the earth is covered with flowers, glowing poppies and tulips, green grass and Irises and many other flowers. Great flocks of birds soar in the air, and camels graze among the cupola-like "kibitkas" of the Turkomans. Towards the north the view is open, but to the south the low slaty heights of the Kopet Dagh on the Persian border, obstruct the view.

We enjoyed this beautiful scene all day. Next day all was changed, for now the train speeds through the aweinspiring waste of the sand-desert. It is as RADDE has said, a stormy sea frozen into stillness; enormous ocean-waves without motion, only the foam on the crests is active, it is the sand rising in clouds like smoke. As far as the eye can reach all is greyish-brown sand. Not a plant! Yes there is one, a grass on the top of a dune, its coarse leaves lashed by the wind. More come into view and then we look curiously at the Switch-plants. They stand in the loose sand which is whirled round them and their slender leafless branches are driven before the wind. In reality there are several species but they are all alike switches or rather small leafless birch brooms, and they are leafless, or look so at first sight.

Then the train passes the Oxus or Amu Darya whose brown water coming from the Pamirs flows below us while we slowly cross the long bridge, which extends to 3 kilometres. 
The river banks are occupied by poplars and immense tufts of grass (Erianthus).

East of the Amu Darya we are on the desert of shifting sand again, and then the large oasis of Buchara is reached. The sun is shining on green fields, tall poplars and brown clay houses. This is our first camping place.

During these past days we have while traversing them acquired a preliminary knowledge of three of the greater plant formations of Transcaspia, namely the Clay-desert, the Sand-desert and the Riverside Thickets. The first we have seen in its luxuriant spring aspect characterized mainly by shortlived annuals; the second, seen at its worst, is distinguished by the exceptionally severe conditions under which only a few, specially equipped plants are able to live; the third is a fringing or gallery-forest ("Galleriewald") rigidly limited to the banks of the river.

It is the object of this contribution to describe these and other formations more closely. First, however, it will be necessary to consider the plant-formations of Transcaspia recognised by earlier writers and to explain our choice of names used to designate the formations in the following pages:

In the Caspian Depression-territory - extending from the southern limit of the forest in European Russia to the Caucasus and the border-mountains of Persia -, Grisebach recognises three formations, namely Grass-steppe, Sand-steppe and Salt-steppe (I p. 455). The first of these has a soil with humus and is the south Russian steppe which does not come within the scope of this work. Under Salt-steppe he records a series of other "formations" (p. 461) between which, however, he does not distinguish sharply. The following three are noteworthy: 1) Dry Clay-steppe with a few Saxauls, annual Chenopodiaceae or Artemisia fragrans or Anabasis aphylla, 2) More moist steppe with bushes of social Salsolaceae and Tamarisks, 3) Salt-swamps.

Borszczow distinguishes 3 "areas" (see p. 24), namely Salt-desert, Clay-desert and Moving-sand-desert besides two, which lie outside our area. Finally Antonow has in addition to "Mountain-Flora", five formations namely Loess- 
desert, Loess-steppe, Promontory or Stone-steppe, Sand-desert and the riverside thickets.

Of the authors named, Borszczow, as already stated, does not use the word formation, and AnTonow, who uses it, defines it as a "natural plant-group". Grisebach's definition of formation is well known (1838): A group of plants having a definite physiognomic character, and characterised by a single social species or by several species which although differently organised, yet have some feature in common.

Though there is disagreement between the concept of formation held by these authors and the concept maintained in the following pages, it is in this case of no vital importance. In Transcaspia the natural conditions are so uniform, and the boundaries so distinct, at any rate between the more important formations (those observed on our first railroad journey), that there is very little probability of any misunderstanding.

The formations to be described by us are regarded as plant-communities, belonging to certain growth-forms always the same within the same formation - and these are determined by and adapted to common conditions. This is the same conception as WARMing has (1909 p. 140). On practical grounds the conditions of soil will be employed in the following descriptions as the principal basis of classification.

The Transcaspian formations or "areas", described by different authors are given in the following table arranged in order to show their relationship. In the column to the right will be found those formations which I regard as necessary for distinction.

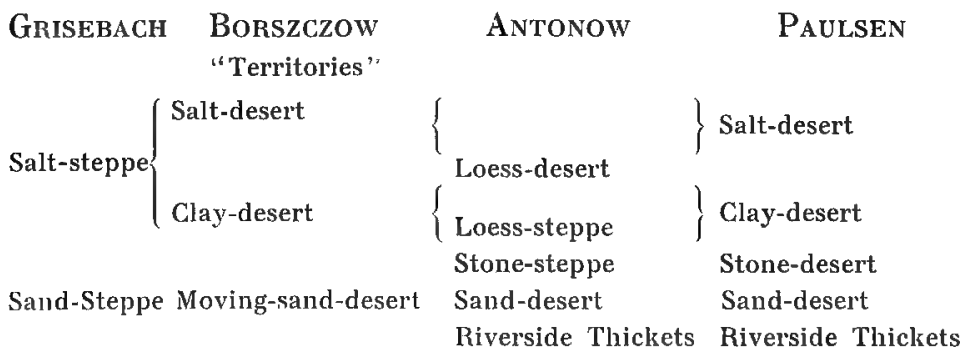


It will be understood that the Salt-desert is regarded by Borszczow and Paulsen as a part of Antonow's Loess-desert of which another part together withe Loess-steppe is referred to Clay-desert. The salt-desert of Borszczow is not however the same as that of Paulsen.

The vegetation of the lowlands of Transcaspia is in my opinion, to be classified under the following natural formations :

1. Salt-desert corresponding to parts of Antonow's Loess-desert.

2. Clay-desert corresponding to AnTonow's Loess-steppe and parts of his Loess-desert.

3. Stone-desert. Under this heading are placed not only deserts with stony soil, but also the small, scattered groups of mountains.

4. Sand-desert.

5. The Riverside Thickets.

The outstanding features of the formations are sufficiently indicated by the above titles.

The principal factor which determines the formations is the amount of water. The riversides and the salt-deserts have the moister soil, the clay-desert has the driest, in the physiological sense at least. The physical constitution of the soil also plays a great part especially all that is involved in the difference between sand and clay. Beyond these the lifeconditions of the plants in the different formations are still very obscure.

To the natural formations one should add the tilled soil, the formation of cultivation, which in this work is left out of consideration. It only amounts to 2 per ct. of the total area (Schwartz p. 576).

In selecting names for the formations I have avoided the word Steppe. Like Schimper, Krassnow (1899) and Tanfiljew (1903, 1905), I prefer to recognise grass-steppe alone as Steppe (see p. 41). Carbonate of lime is here the dominant salt, the vegetation is on the whole uniform all the year round and has produced a surface layer of dark soil. The desert, on the contrary, is an open formation on soil which 
has not been greatly transformed by the vegetation, and which is rich in sulphates and chlorides.

The vegetation provides a further difference between the steppes of southern Russia and the Transcaspian deserts. Without entering into details on the vegetation of the steppes, we may take for instance Gruner's description (p. 106) which states that during summer and autumn a large proportion of non-xerophilous or only slightly xerophilous plants appear (Melilotus, Marrubium, Teucrium, Chenopodium, \&c.). In Transcaspia the summer and autumn types of vegetation are quite distinct, as will appear from the following chapters.

The same has been pointed out by Krassnow (1899), namely that the plants of the desert have a special organisation which enables them to endure the severe drought. (He says this without any reservation although the ephemeral plants might well be taken as exceptions.) Steppes on the contrary are covered by a grassy vegetation not specially adapted to droughts, and therefore liable to be scorched. As a further disparity between desert and steppe, Krassnow points out that the former cannot produce crops except with the aid of irrigation whereas the steppe can. Both are devoid of forests.

It seems moreover to be of importance that trees are absent from the steppes (the grass-steppes), while the desertvegetation in a considerable degree is characterised by trees and bushes. This was also pointed out by Grisebach (1872, I, p. 400). His view was, that desert is not a scientific definition but means "uninhabitable places", and, as already stated (p. 45), he included all formations under "steppe". His opinion is that the different forms of steppe are not caused by climatic conditions but originate in the soil. Where there is clay near the surface the water from precipitation does not penetrate deeply so that grasses and herbaceous perennials can live, and we find a grass-steppe. But where sand stones and rocks attract the water to greater depths, we have a desert, which is richer in ligneous plants than the grass-steppe, because their roots go down deeper. In the desert the surface consists of permeable strata.

Apart from the fact that the desert is certainly depen- 
dent upon the climate and not upon the soil, and that its surface in many places consists of impermeable clay, the reasoning of GrisEbach has a great amount of truth. KosTYTSCHEFF, IsMaILSKy and Krassnow independently point out the same circumstance in the Russian steppes, that the absence of tree-growth (among other things) is caused by the surface layer of the soil not permitting the water to penetrate into the depths. With reference to Transcaspia, Ronanowsi states (p. 56) that in layers of gravel under the loess, water is found and is widely diffused under the soil. This may be rain or snow absorbed through sand ${ }^{1}$ ), or it may originate from rivers which have sunk into the sand. "Consequently the sand-steppes of Turan cannot be said to be absolutely waterless."

Here then we have probably the reason - or one of the reasons - why the desert has trees, the steppe none. The presence or absence of trees taken along with the relation of the water to the soil, seem to me so important, that they, together with the climatic conditions and the conditions of the soils, must be regarded as distinguishing characters between steppe and desert.

For my own part I regard the steppe (grass-steppe) as mainly a closed plant-formation (or group of formations) occurring on soil rich in humus without excess of sulphates and chlorides, and with a comparatively moist surface-soil; the vegetation consists of herbaceous perennials, undershrubs and annuals while trees and bushes are wanting.

The soil of the desert, on the contrary, is devoid of humus or very poor in humus, and contains many sulphates and chlorides. The subsoil is (always?) better supplied with water than the surface. The formations are very open and they frequently include trees and bushes.

This attempt to explain the terms steppe and desert may not lead to any sharp distinction between the two, so much the less

1) In this connection it may be pointed out that the steppes of southern Russia have their maximum precipitation in summer so that the water will evaporate quicker than in Transcaspia where maximum occurs between winter and spring.

O. P. 
as it is mainly based on studies in South Russia and Transcaspia. But the distinction between steppe (grass-steppe) on the one hand and desert on the other, seems easier to apply than the one maintained by most authors, for instance WARMing and VAHL. Phytogeographical literature defines so many different kinds of steppe - Meadow-steppe, Grass-steppe, Vermuth-steppe, Salt-steppe, Sand-steppe, Bush-steppe and even such types as Orchard-steppe poor in grass, Tree-steppe, Steppe-forest \&c. (ENGLER 1910) -- that it is hard to see what they have in common except that all are more or less xerophilous formations.

What Schimper, Krassnow and Tanfiljew have termed steppe, is not an extreme xerophilous formation. The Sandsteppe ("die Sandpuszte", Adamovic p. 320, Woenig) belongs to the steppe type, but differs from the "Sand-steppes" described from Transcaspia which are deserts. Steppes, according to the definition given here, do not occur in Transcaspia at all.

\section{CHAPTER 6}

\section{Formation of the Salt-Deserts.}

Under this heading are classed localities where the plants grow on soil so saline that the salt crystallizes out as a layer covering the surface. The conditions which render this possible are: 1) the presence of salts in solution, 2) facilities for the solution reaching the surface. It is essential for this that the underground water-table is not located at too great a depth. It is usual therefore to find salt-deserts in depressions. The constant evaporation from the surface causes the salts to crystallize out, and a fresh solution diffuses constantly from below. Where the soil is loess, this upward diffusion takes place rather easily on account of the capillary structure.

"Ssor" is the name given by the natives to wet saline flats. They are often found among dunes and are said to be generally flooded during winter and spring. A "Ssor" is not a very pleasant sight (fig. 2). The ground is flat and white like 
snow so that in the strong sunlight it is dazzling to the eyes. Very often this is all that is to be seen, one can walk hundreds of paces without finding a plant. In some places the salt crackles under the feet, in other places the soil is soft to the tread because under the salts, it is moist or wet. One slips frequently on the greasy greenish-brown clay. In such a place the water-table may be barely 1 metre below the surface.

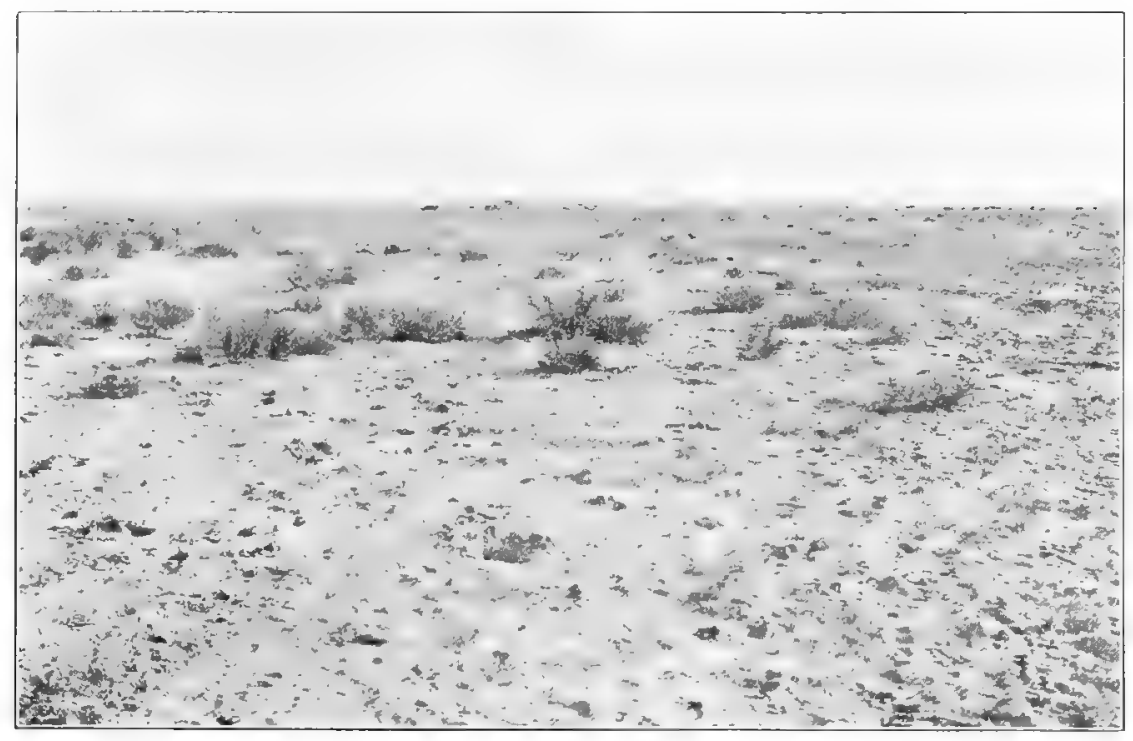

Fig. 2. "Ssor" (Salt-desert) near Buchara. The ground is white with salt and occupied by scattered Aeluropus littoralis and Halostachys caspica (the bushes). Month of May.

In small depressions the soil is brown, because here it is so wet that the salts are kept permanently in solution. Also on small elevations the soil may be brown and only coated with a thin, granular, hard incrustation. Towards summer the salt in some places becomes dry and dusty.

The salts are mainly sulphates especially of sodium and magnesium, but there is also gypsum and common salt ${ }^{1}$ ) Crystals of gypsum are sometimes found in the earth.

1) See above p. 9. 
The vegetation is exceedingly scanty. At long intervals small stunted bushes of Halostachys caspica may be seen, a leafless dwarf-bush with assimilating shoots like those of $S \alpha$ licornia.

Halocnemum strobilaceum, a small bush, distinguished by its globular dwarf-shoots, has a similar appearance. Also Lycium ruthenicum is a bush with fleshy cylindrical leaves; like the other two it scarcely attains the height of one foot on this wet saline soil, but under favourable circumstances it may become many times larger. (See for instance the chapter on the riverside thickets).

A number of annual species are also characteristic for the salt-desert, or may be found there. The more important of these are: Salicornia herbacea, Halopeplis pygmaea (this has exceedingly succulent, thick and almost globular leaves), Suceda setigera, arcuata, corniculata etc., Bienertia cycloptera, Halogeton glomeratus, Statice leptostachya and spicata, species of Salsola, (S. crassa, obtusifolia etc.) and Halimocnemis which, however, usually occurs more frequently on somewhat drier soil. The same holds good for Frankenia pulverulenta andthe prostrate undershrub Frankenia hirsuta, also for Anabasis, some species of which are herbaceous perennials, some undershrubs, and all with leafless assimilating shoots. Other herbaceous perennials are Statice otolepis with broad leaves arranged in rosettes, and Aeluropus littoralis, a prostrate bluishgrey grass.

My experience is that Aeluropus, Halostachys, Halocnemum and Salicornia are the species most frequently met with on "Ssor". On one occasion near Chodsheli (in July) I found Phragmites communis in a locality of this kind. The soil was moist and brown at the depth of a few centimetres, but the surface was dry, white and dusty with salts. The Phragmites plants were small, and with surface-runners as when the species grows on wet sand in the north of Europe, but these runners did not exceed $30 \mathrm{~cm}$. in length. Tamarix bushes, half a metre high, were growing scattered along with Phragmites.

The species mentioned above are all Halophytes. Most of them are Chenopodiaceae and belong to the succulent, 
leafless or leaf-bearing type, with the exception of Aeluropus, Statice, Phragmites and the salt-excreting Frankenias and Tamarisks. Their internal structure is dealt with in chapter 13 .

Most of the species are annuals and all are summerplants, none being ephemeral spring-plants. The annual Statices (S. leptostachya and spicata) are probably not very longlived, but on this point I have no definite observations.

As regards the natural development of "Ssor", I can only say that on one occasion I observed that sand from the neighbouring sand-desert had drifted across the salt-flats, and sheltering behind plants of Salicornia had formed miniature sand-dunes. If this sand remains long enough it will become permeated by the moisture coming from below, and the salt incrustation must form over it. In this way the surface may be raised a little. This process does not seem, however, to play any great part, because I have always found clay under the salt incrustation, but further examination might perhaps reveal the presence of sand.

That the barrenness of the salt-desert is due to the want of fresh water alone, was illustrated by a striking example seen near Buchara. Here in May 1898, two parallel ditches were dug through a snow-white salt-desert, and the excavated material was made into a mound between them, so that the mound and the double ditch surrounded a square piece of of ground. The inner ditch was connected by a long straight ditch with the irrigation system of some tilled fields in the neighbourhood. The piece of ground enclosed by the mound and the ditches was perfectly green, Aeluropus littoralis having spread so luxuriantly that it almost formed a carpet of vegetation and so dense that it almost suppressed all the other halophytes, only a very few Halostachys being left.

Outside the outer ditch the ground was white with salt and covered with scattered Halostachys caspica and Aeluropus (fig. 3).

The peasants told me that the enclosed piece of ground was made into a field this year, that it had only once been irrigated (through the long straight ditch) and that in the auturnn they intended to sow it with wheat. Mrddendorff, 
however, maintains (l. c. p. 123) that saline soil must be washed for two winters before it is fit to be tilled.

Batpak or Batkak, according to Choroshrin (cited by Musketow p. 655), must be closely related to Ssor. These are swampy depressions with efflorescent salts, and they are nearly always found by salt-lakes and may be partly covered by water. It must be areas of this kind which Borszczow

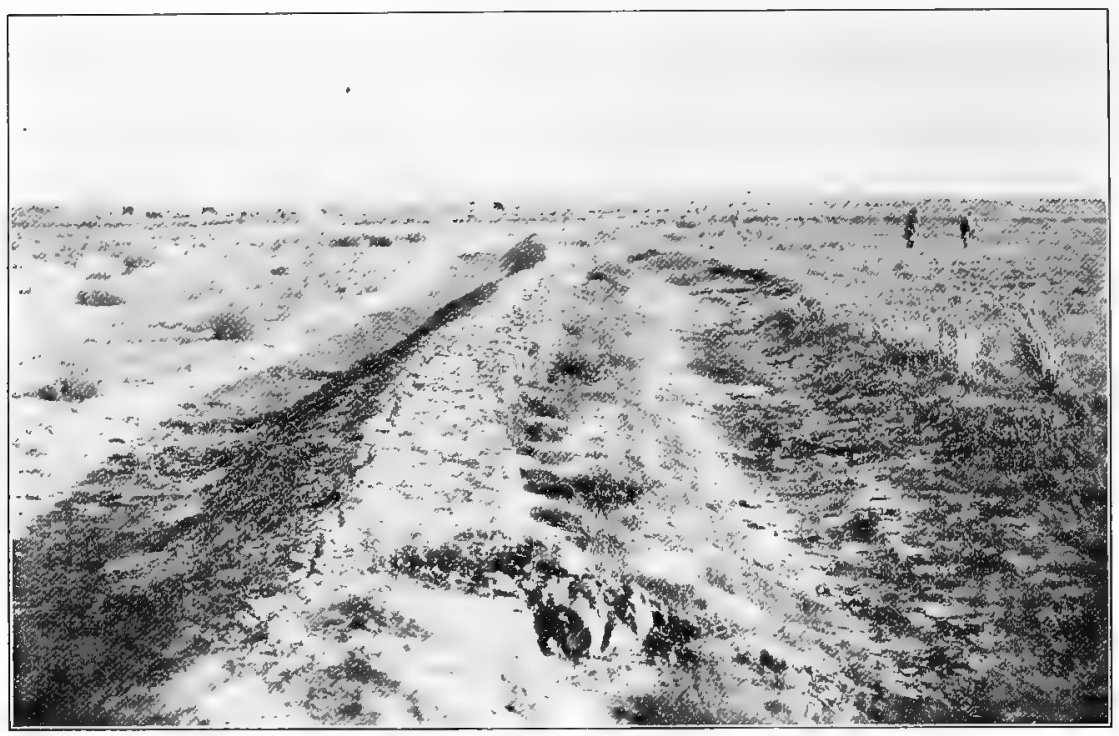

Fig. 3. To the left Salt-desert with scattered Halostachys caspica. The soil to the right of the mound has been irrigated once and is covered with a thick growth of Aeluropus littoralis. Near Buchara in May.

has described as "Salt-deserts" and whose brilliancy of colour he admires so much. ANTonow's "Swamp-lakes" must also be of this same type.

If the above assumptions are correct, Batpak must be more swampy than Ssor. Only near Chiwa have I seen salt-swamps which can be classed in this category. These are small, shallow, stinking salt-lakes, surrounded by a snowywhite salt-steppe which is flat or slightly undulating. The salt-plain is similar to the Ssor described above, and has large tracts without any plants, but in most of the depressions are found fresh green groups of Salicornia or Halimocnemis. 
Some of the depressions have been filled with water, but are now quite dried up and only contain thick incrustations of sodium and magnesium sulphates or common salt (see above p.11). On the banks of the small lakes Salicornia is dominant both in and above the water. Most of the specimens on shore were red, those in the water were generally green. Round the foot of each plant, including the dead ones, there was a granular mass of salt, which reached a couple of centimetres up the stalk. This must have been formed when the water was higher than now (analysis no. 4 p. 11). The following plant-species were found on the bank of the lake. Aeluropus littoralis, low and withered Phragmites (this was in the middle of July), Scirpus affinis. and in the water Ruppia maritima. In a few places, a little way from the banks, low Tamarisk bushes, Alghagi Camelorum and Halimocnemis villosa were mixed with the Salicornias.

These few observations will indicate that the vegetation is mainly the same as on "Ssor", and that the difference between "Batpak" and the former is therefore scarcely of any oecological or phytogeographical importance, at any rate if the water-plants of the lakes are left out of consideration.

"Takyr" is the name given to flat depressions, often of great extent (several kilometres) and which in a dry condition have a hard, clayey and slightly saline surface. They are often found in depressions among the dunes. In spring they are under water and from this fine particles of material transported by water or wind are laid down. Thus, by degrees, stratified water-loess is formed and prevents the water from sinking into the ground. When "Takyr" are dry, the bottom is hard like a threshing floor and the surface cracks and peels off in crusts. These flats are, as a rule, perfectly devoid of vegetation, because, RADDE suggests, they dry up late in the year and at a time when seeds cannot germinate on account of the heat of the sun. I have never seen plants on "Takyr", but RADDE mentions that on certain low sandhills which rise above the water during spring, a few Chenopodiaceae may be found. Along the margins, that is where the water first subsides, a poor "Wermuth-flora" (Artemisiae), is also said to exist, and the stiff-leaved grass Crypsis aculeata 
is said to grow here. These latter species indicate that "Takyr" is also closely related to the Clay-desert.

From what has been said about the Salt-deserts, we can deduce the following characteristics of the formation: it consists of annual or perennial Halophytes of which a few are dwarf-bushes, very few are bushes (Tamarix) and none are trees. The plants grow scattered on a very saline soil. There is no spring flowering period but all the plants vegetate throughout the summer or, at least, far into it. This last feature I regard as the chief distinguishing characteristic between this formation and the Clay-desert.

The formation does not fall in with Grisebach's Saltsteppe or Borszczow's Salt-desert both of which occur to some extent in the Clay-desert. This is indicated by the fact that both authors mention trees and bushes as constituents of the vegetation.

\section{CHAPTER 7}

\section{The formation of the Clay-Deserts.}

Clay-deserts are distinguished here as areas which have a clay substratum, and which do not contain salts to the extent that they to a greater amount come to view on the surface. This concept is to some extent identical with "The area of the Clay-deserts" in Bonszczow, but parts of his Salt-desert also belong here. Anronow's formation of the "Loess-steppe" belongs here, likewise "the Clay-desert" with the exception of the saline places, which are here classed under the preceding formation.

According to many authors, Clay-deserts are very extensive in the lowland of Transcaspia (comp. Borszczow above p. 25, and Antonow p. 32), and Richthofen regards them as "the true normal steppes of Central-Asia".

The soil of the Clay-deserts differs from that of the Salt-deserts by its greater dryness. When these two formations are found together, the Salt-desert always occupies the deeper parts. The saline ground-water cannot diffuse up to 
the surface of the Clay-desert, therefore no salt, or only a little, crystallises out there. It must be kept in mind that the ground-water in the desert is almost always saline, and that fresh water is only found in the underground streams which have washed out the salts from the water-bearing layers (BAER 1856 p. 47).

The clay forming the surface of the desert is mostly loess in the southern parts. Pure compact clays (Aralo-Caspian formations?) are also said to occur in the Clay-desert (Bonszczow, see p. 25), but I have not seen any.

The Loess includes a proportion of fine sand, sometimes quite as much sand as clay or even more, and it frequently contains mica. (OBrutshew, cited by Radde 1899 p. 19). It is moreover unstratified, rich in lime, very porous and totally devoid of stones. When water is present, loess is a very fertile soil for vegetation. Below it, at a depth of $7-10$ metres, layers of sand are generally found alternating with thin layers of clay containing gypsum.

Because of its porous structure loess absorbs water easily, but as the surface-soil is generally compact, that only absorbs water to a slight degree. The result is that the water from precipitation easily runs off, or remains on the top and evaporates. As loess has in addition a high water-capacity $(59,5$ per ct. of dry weight, Clements), the upper layers retain the water absorbed, so that it does not penetrate deeply and is therefore exposed to rapid evaporation ${ }^{1}$ ). According to Wysotzki (cited by Ramann p. 402) there is found under the "live" layer, which contains the water of precipitation, a "dead" layer with its water-content unchanged, below this follows the layer containing ground-water (if there is any). Accordingly loess is not favourable to tree-growth as it prevents water from sinking down to where the tree-roots can get it (comp. above p. 48).

It is likewise of importance that loess being a rather fine-grained soil retains the water, so that the roots of plants can only absorb a proportionately small percentage. The percentage available to the plants CLements calls Chresard, as

1) Kostytscheff p. 113, Ismailskx p. 24, Ramann 1905 p. 415. 
opposed to Echard, the percentage retained by the soil and which the roots cannot absorb even if the plant wilts. According to Clements (p. 31) loess can absorb 59,3 per ct. (of its dry weight), and of these 49,2 per ct. are Chresard, 10,1 per ct. Echard.

In the case of clay Clements gives $9_{, 3}$ per ct. Echard, Sachs has 8 per ct. (Vorlesungen, 2. Aufl. p. 239). Sand can absorb much less water, but on the other hand, almost all the water is available for the plants: the Echard is very small (Comp. E. Gain 1895).

The capillarity of loess is considerable, so that where ground-water occurs it is able to raise this higher than sand, although the rate of movement is slower. On the one hand this process brings the deeper-lying water within reach of shorter roots, but on the other hand it promotes the evaporation of ground-water in loess as compared with that in sand.

Since the surface of loess is even and fine-grained, more water will evaporate from it than from a sand-surface $\left(R_{A}-\right.$ MANN p. 262). Another factor which promotes this is that loess has a dark colour and is therefore strongly heated by the sun. Middendorff records the following surface-temperatures on a sumny day in May. On loess $62^{\circ} \mathrm{C}$., on a white salt-incrustation $45^{0} \mathrm{C}$. The lower temperature of the saltincrustation is due to combined evaporation and reflection.

Thus it will be seen that loess under dry conditions is as unfavourable to vegetation as it is favourable when water is present.

The maximum of precipitation (p. 17) for the areas we are considering occurs during winter or spring, whereas the summer is practically rainless, but very hot. The plants of the clay-desert which live through the summer in a vegetative condition cannot be adequately supplied by the small proportion of the comparatively limited spring rain which remains in the clay-soil. These plants, the Summer-Plants, must therefore supplement their water-supply from the saline ground-water. Thus one finds that in the true dry Claydeserts where neighbouring mountains do not make the conditions specially favourable, the plants are almost all Halophytes. Conspicuous amongst them are many Chenopo- 
diaceae both annuals and perennials. These plants do not die or go to rest till the autumn. Schimper calls such plants "Ground-Water Plants".

Another group of plants satisfy their water-requirements from the precipitation of the winter and spring, the melting snow and rain-water which is stored in the upper layers of the soil. When the dry hot time comes (in May-June) most of the available water (Chresard) from these strata evaporates, and they become very dry. What water remains becomes more concentrated and saline through evaporation (BERNATSKY p. 209), and as the plants dependent on the water in the upper layers - the Spring-Plants - are not xerophilous or only slightly so, the increasing heat soon makes them wither. Before this takes place, however, their development is finished, and they have dispersed their seeds. Most of the spring-plants are annuals or ephemerals, as VolkENs terms them, but there are also some bulbous plants and other perennials, especially in the more favourable localities. These perennials go to rest when summer comes, and assimilate and bloom only in spring.

This distinction between a spring-vegetation and a summer-vegetation has long been known for many deserts and steppes. (It is also present, though perhaps less pronounced, in the whole region of temperate winter-rains). Grisebach (1872 I p. 449) has already recorded Artemisia as one of the few perennials ("Stauden") which vegetate through the summer, and he also states that most annual plants die quickly during the spring, whereas some annual Chenopodiaceae live through the summer, blossom in the autumn, and do not die till the frost sets in. - The spring-flora of the SouthRussian steppe has been described among others by Gruner and Tanfilsew, that of Egypt by Voliens, and that of the desert-territory of western North-America by MAC DougaL, Thornber and others. Here we find two maxima of ephemeral plants corresponding to the two rainy seasons of winter and summer.

We shall first describe the Transcaspian Clay-desert in its Spring aspect, and afterwards attempt to present a picture of the more sombre aspects of Summer and Autumn. 
Certain forms of the sand-desert also have these two aspects, and one finds here in places a quickly fading Springvegetation; this is referred to in chap. 9.

The spring-flowering period of the Clay-desert attains its richest and finest development at the foot of the mountains, for instance at the Persian Kopet Dagh and the western Thian-Shan. In such places the amount of water is greater than on the plains, and this causes in itself a richer vegetation of spring-plants. Moreover there is often cultivated land at the foot of the mountains, and weeds from there along with plants from the neighbouring mountain slopes mix with the plants of the desert (Korshinsky see p. 36). Such deserts, rich in vegetation, TANFILJEw calls LoessDesert-Steppe (the exact term used is not easily translated from Russian!). "Semi-Desert" will be used to indicate them in the following account.

A sketch of such an area has already been given (p. 44). In spring it certainly does not resemble a desert. Looking at the mass of flowers one obtains an overpowering impression of richness, vigour and luxuriance. A closer examination, however, reveals traces of the desert nature.

The plants do not form a close carpet or they do so only in patches, whereas in other places the soil is quite naked especially where salts crystallise out as a light dusty covering which gives the soil a greyish colour. Here and there among the fresh-green flowering plants one finds a grey Artemisia or an almost leafless low chenopodiaceous bush; they are still very backward in their development and one can see that their season is still to come. In a few places there are small stretches of moving-sands in the midst of the flower-decked area; these are bare or scantily covered with scattered coarse tufts of grass or low grey bushes.

The following is a list of the plants which bloom during the spring in the Semi-desert, together with a short summary of the characters they have in common.

Grasses are the principal constituents of the vegetation, and of these Poa bulbosa is by far the most dominant, that and the less important Hordeum secalinum are the only perennial grasses. The shoots of Poa bulbosa have, as is well 
known, a bulbous swelling at the base, and the resting buds on this are well protected both against drought and cold. I have always found the ears viviparous. Other grasses of importance are: Apera interrupta, Trisetum Gaudinianum, Festuca ciliata, Nardurus tenuifolius, Koeleria phleoides, Triticum Aegilops and orientale, Agropyrum squarrosum, Schismus minutus, Bromus tectorum, oxyodon and Danthoniae, Hordeum

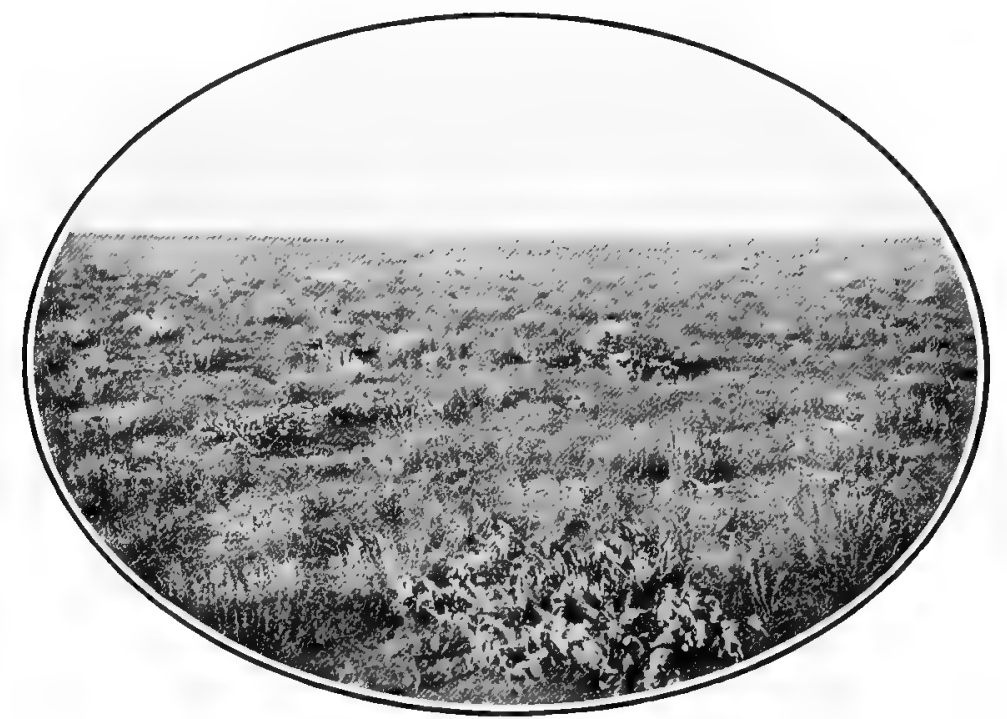

Fig. 4. Semi-desert at Chawast N. E. of Samarkand. In the foreground half-withered leaf-rosettes of Ferula Asa foetida. Arlemisia sp. dominant, with Poa bulbosa, Haplopyllum lasianthum, Carum turkestanicum, Eremostachys labiosa. Month of May.

crinitum and secalinum, Boissiera bromoides. All these grasses are annuals, rather low-growing, scarcely a foot high, and with flat leaves.

The "flowering herbs" include a number of annuals. The poppies first attract the eye: Roemeria rhoeadiflora, Papaver arenarium and pavoninum. Then one sees a great number of Cruciferae (Malcolmia africana and Bungei, Alyssum marginatum and linifolium, Sisymbrilum-species, Goldbachia laevigata, Leptaleum filifolium, Cryptospora falcata, Euclidium syriacum, Chorispora tenella); also Boragineae (Anchusa hispida, Arnebia 
linearifolia, Asperugo procumbens, Lappula-species, Heliotropium europaeum, Onosma hispidum, Nonnea picta), Umbelliferae (Aphanoplema capillifolia, Carum confusum and turkestanicum,

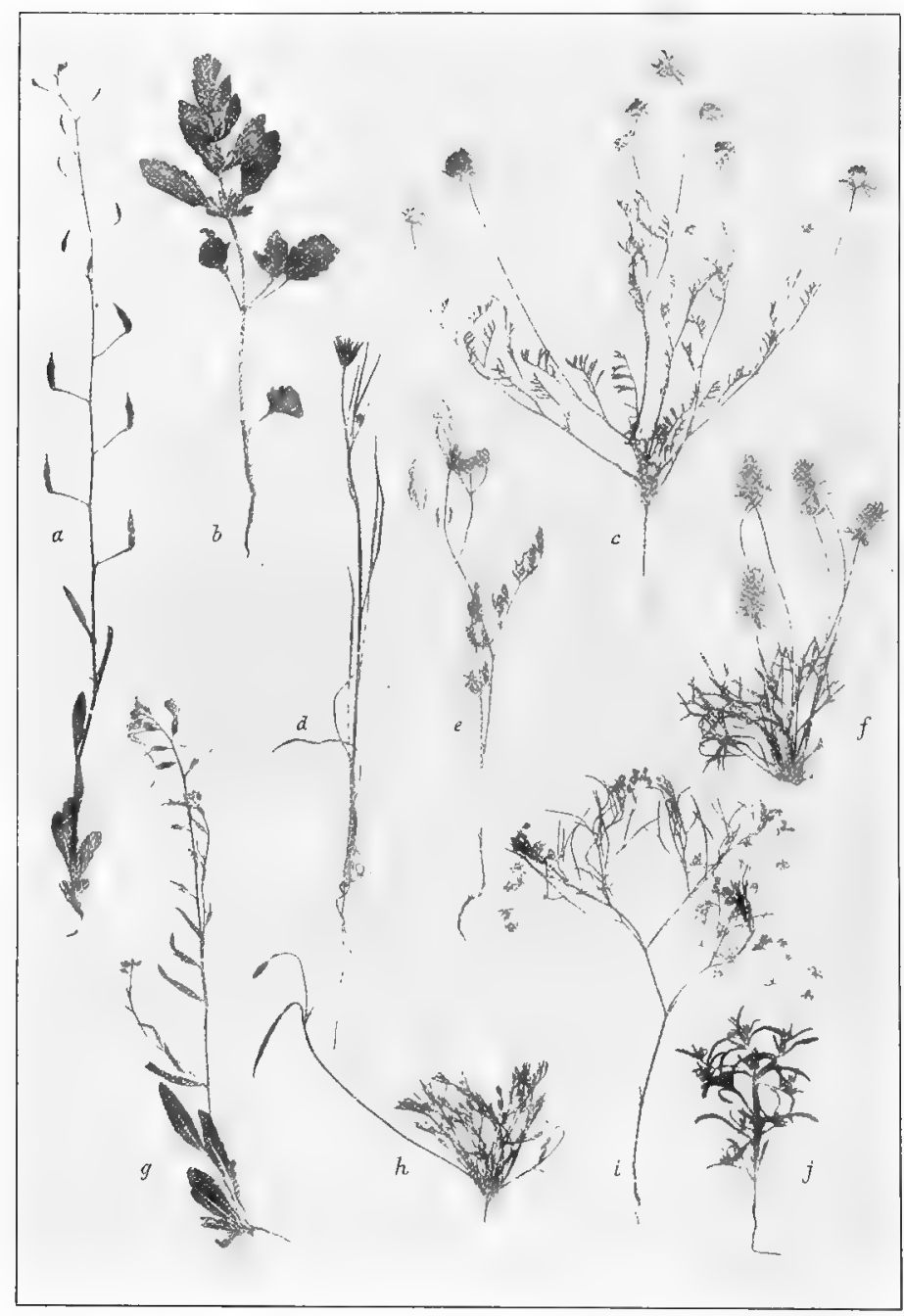

Fig. 5. Representative ephemeral plants from Clay-desert: a, Goldbachia laevigata. b, Lallemantia Royleana: c, Matricaria lamellata. d, Koelpinia linearis. e, Cancalis leptophylla. f, Ceratocephalus orthoceras. g, Malcolmia Bungei. b, Hypecoum pendulum. i, Acanthopleura capillifolia. j, Lappula spinocarpos. 


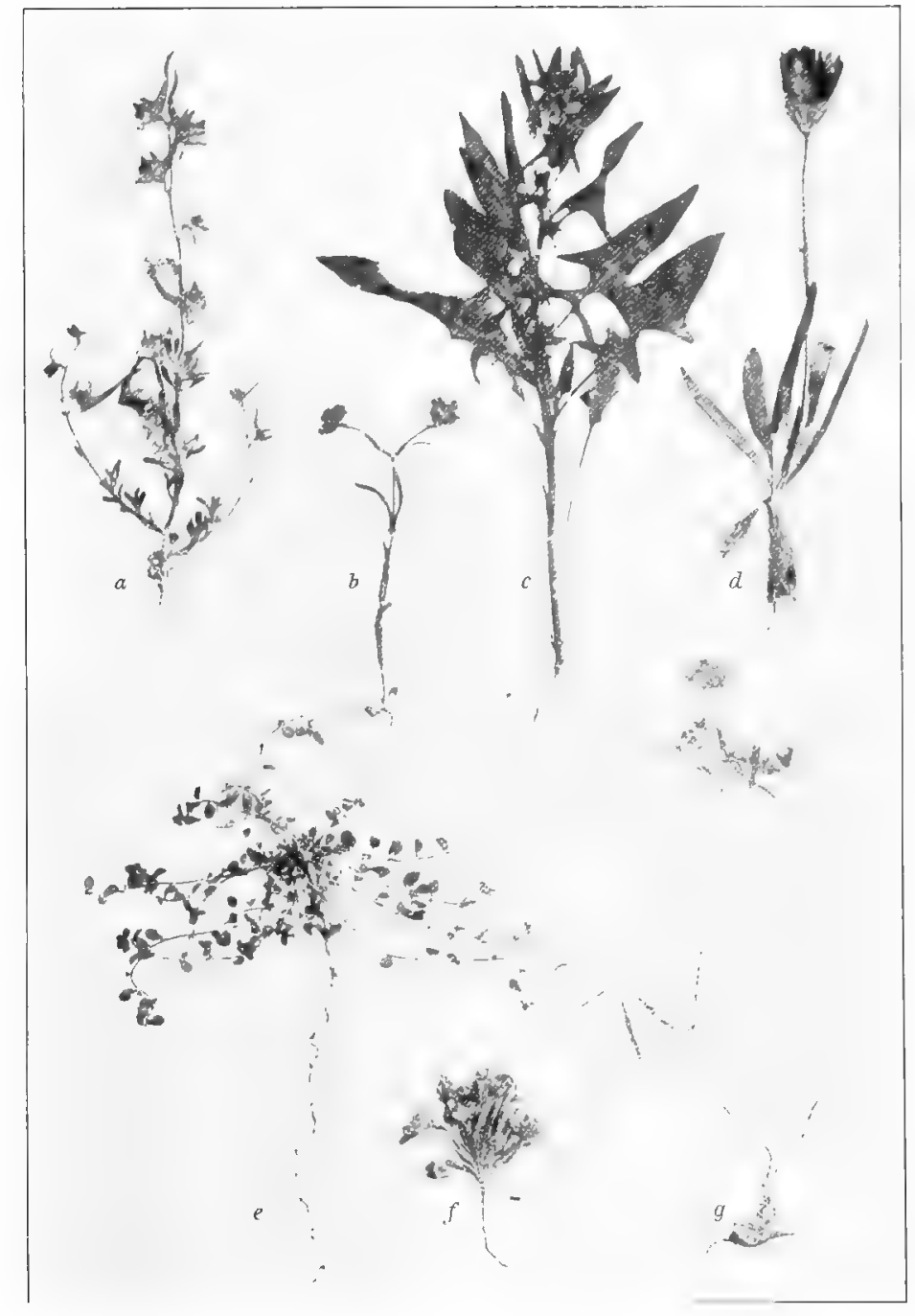


tetranda, Koelpinia linearis, Matricaria lamellata, Ceratocephalus falcatus, Hypecoum pendulum and trilobum, Trigonella

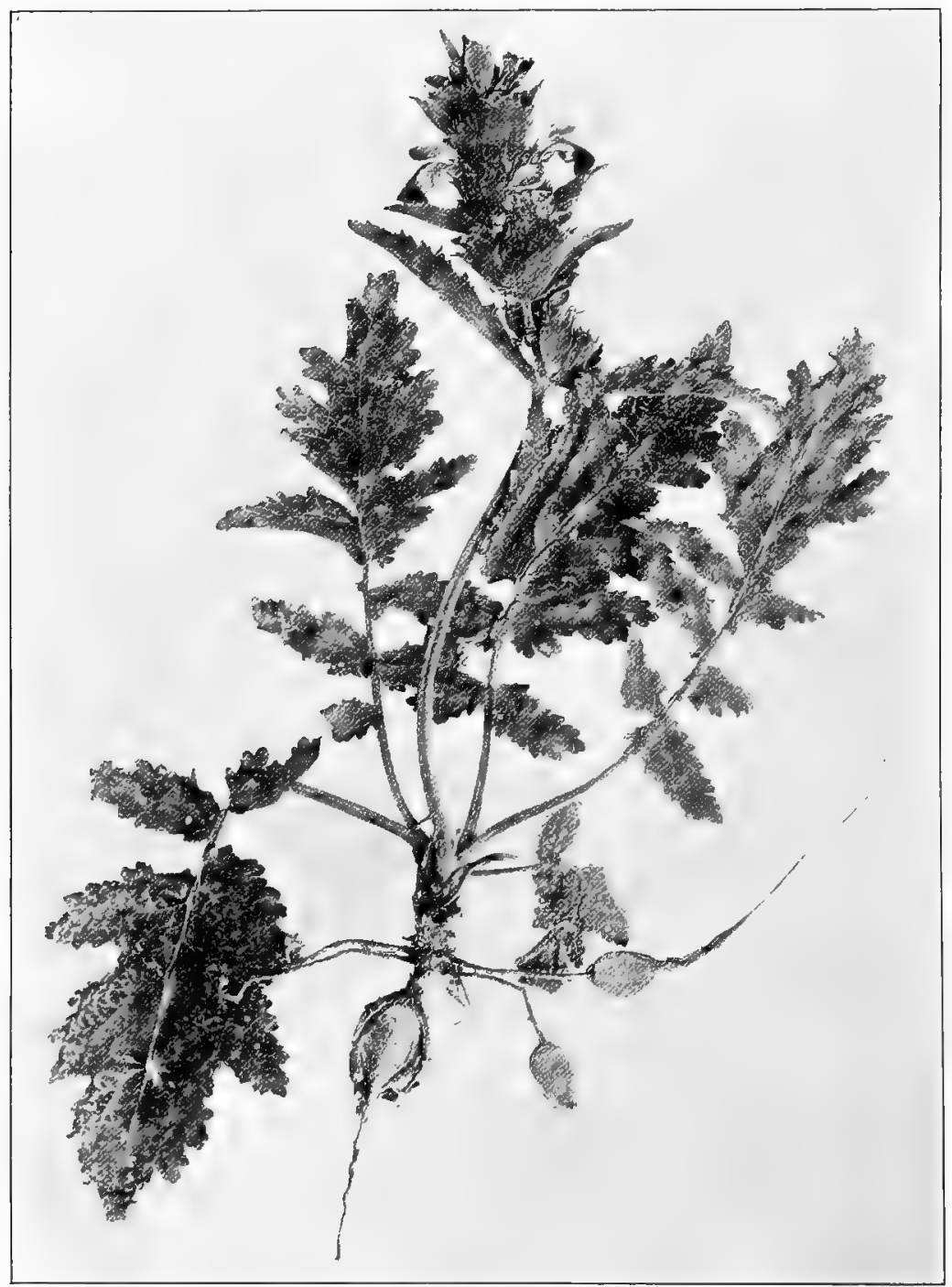

Fig. 7. Eremostachys labiosa. May.

monantha and longiflora, Euphorbia pygmaea, Galium tricorne, Delphinium rugulosum and persicum, Nigella integrifolia, Astra- 
galus filicaulis and camphylotrichus, Plantago lachnantha, Tribulus terrestris.

Here and there in patches are found the stiff-haired Chenopod Halocharis hispida, or Bassia sedoides, and often on saline spots there is the very small succulent Tetradiclis tenella.

Noteworthy amongst the perennials which bloom in the spring are a fine red Tulipa sp., Ixilirion Pallasii, with blue blossoms, Allium Tschulpias and other species, Gagea reticulata, the tuberous geophytes Geranium tuberosum and Leontice incerta, besides Iris caucasica, falcifolia, etc.

Eremostachys labiosa (fig. 7), a foot-high Labiate with handsome Acanthus-like foliage and large light flowers is so plentiful in places that the green grass is dotted over; it has tubers and is a hemicryptophyte like Ferula Asa foetida. This latter also dominates large areas in some places with its large yellowish-white compound umbels rising a metre or more above the ground, in other places it is represented only by rosettes of large dissected leaves which are already turning yellow at the end of May; the plant has tubers and thick rhizomes.

Rheum tataricum occurs locally spreading its large bossed leaves, a metre wide over the ground. I have not seen it in bloom, but to judge from an illustration published by $\mathrm{T}_{\mathrm{AN}}$ FILJEW (1903 p. 390) the inflorescence is strongly branched and rather low. In the middle of May the leaves are already turning yellow.

Other hemicryptophytes found during spring in the semidesert are: Astragalus Alopecias with vigorous prostrate shoots which have multipinnate silver-white leaves and dense yellow flower-heads, A. sogdianus, A. macronyx with its yellow blossoms on short stalks at the base of the long leaves, $A$. mucidus, flexus, orbiculatus, Petunnikowi and other species, Solenanthus petiolaris, Gentiana Olivieri, several species of Scorzonera with tubers, Taraxacum sp. Dianthus crinitus and angulatus, Ranunculus Sewerzowi, oxyspermus and other species, Haplophyllum lasianthum, Lepidium Draba, Andrachne telephioides, Onosma hispidum, Achillea micrantha, Cachrys didyma, Carex stenophylla var. desertorum, species of Carum, Peucedanum, 
Tragopogon, etc. Here and there may be seen the erect blue inflorescences of the parasitic Orobanche amoena.

The plants just mentioned belong to the Spring-plants. Both annuals and perennials are represented, the former being predominant. The perennials are either bulbs, tuberous geophytes or hemicryptophytes. Rhizome-geophytes seem to be absent, with the exception of Carex stenophylla which is generally a sand-plant; nor is the stiff clayey soil favourable to them.

The spring-plants, with the exception of Ferula Asa foetida, are low, ranging from a few centimetres up to about $30 \mathrm{~cm}$, and they are as a rule soft pliant erect herbs with no pronounced xerophytic structure (see figures 5,6, 7). A frequent character is that the leaves or the leaf segments are narrow, linear or sometimes filiform (Leptaleum, Euphorbia pygmaea, Valerianella, Koelpinia, Caucalis, Aphanopleura, Carum confusum, Peucedanum \&c,), and generally hairy. The Astragalus species have multipinnate leaves, A. mucidus with about 20 pairs of leaflets, $A$. macronyx about 30 pairs.

Plants with broader, elliptical or ovate leaves are less common, for instance Euclidium syriacum, Malcolmia africana, Goldbachia laevigata. The leaf-blade in most of them is downy or setaceous, while Alyssum marginatum and several Cruciferae have stellate hairs. Cousinia and Galium tricorne are thorny. A good many plants occur which are glabrous or nearly so, for instance: Koelpinia, Trigonella, Valerianella, Aphanopleura, Peucedanum, Goldbachia, Spinacia, Hypecoum.

Erect and short stems are the most common. The occurrence of a number of plants with prostrate stems (e. g. Arnebia decumbens, Trigonella, Galium, Leptaleum filifolium, Andrachne telephioides) is a natural feature of a vegetation which is not dense; between the plants there is enough space and light for prostrate stems. These do not apparently give off roots; there are neither above-ground runners nor subterranean ones.

A few rosette-plants occur, both annuals and perennials. Annual rosette-plants are represented by Hypecoum, Plantago lachnantha, Ceratocephalus, perennials by Taraxacum, Gentiana Olivieri. There are several semi-rosette-plants (RAunkJar 1905 
p. 390) i. e. plants with the greatest number and the most vigorous leaves placed at the base of the stalk: Ranunculus oxyspermus and Sewerzowi, Eremostachys, Astragalus macro$n y x$ and sogdianus, Cachrys didyma, and to these may be added a number of ephemerals e. g. Malcolmia Bungei and africanum, Sisymbrium pumilum, Goldbachia laevigata.

The presence of rosette and semi-rosette plants is also in accord with an open plant covering, since a dense vegetation will favour plants with elongated shoots and high-placed leaves.

As regards the floral features, small flowers seem to be more abundant than large ones, and white and yellow flowers are more frequent than blue or red although the red species, such as the poppies and tulips, are often prominent when they occur in masses.

Some idea of the diversity of the spring vegetation of the Semi-desert may be obtained from the following representative lists of plants made in various localities.

1. At Bami west of Askhabad; April 24 ${ }^{\text {th }}$ : Poa bulbosa, Roemeria rhoeadiflora, and a red species of Tulipa are dominant. Other species: Asperugo procumbens, Euclidium syriacum, Malcolmia africana, Myosotis sp., Hypecoum trilobum, Spinacia tetrandra, Ixilirion tataricum, Iris caucasica, Lepidium Draba and perfoliatum, Trigonella monantha, Sisymbrium Sophia and pannonicum, Koelpinia linearis, Matricaria lamellata, Papaver arenarium, Anagallis sp. and a few grey Artemisias. Beside a house were some willow-bushes with catkins, but no leaves.

2. North of Dshisak at the foot of West-Thianshan; May $7^{\text {th }}:$ Poa bulbosa and a grey strongly aromatic Artemisia in places form the whole vegetation.

3. Other places (near Balan Hur) are much richer, and in addition to Poa, poppies and tulips, one finds Ixilirion Pallasii, Carex stenophylla, Malcolmia Bungei, Cryptospora falcata, Euphorbia pygmaea, Leptaleum filifolium, Astragalus sogdianus, macronyx, mucidus, Solenanthus petiolaris, Gentiana Olivieri, Eremostachys labiosa, Ranunculus Sewerzowi. 
In the true clay-desert, which is drier than the semidesert, I had no opportunity of seeing the spring-vegetation. That ephemeral species also occur here is known from BASINER, Borszczow (see above p. 26) and Radde. From the last named author $(1899$, p. 26) is taken the following description of an area near the eastern shore of the Caspian Sea, visited on April $28^{\text {th }}$ :

"Ist diese Sandzone passiert, so kommt man, direkt nach N. wendend, auf festerem Lehm, zum Teil mit Salzgründen und in die elendeste Salsola- und ArtemisienSteppe oder besser gesagt: Wüste."

And later on he says:

"Die arme Flora bietet immer dasselbe, im Ganzen kann man hier kaum 15 Arten finden. Gagea reticulata steht in Samen, Hordeum murinum, Boissiera bromoides, dieselbe Kamille, dieselbe Allium wie bei Tschikisljar, Ceratocephalus falcatus, Geranium oxyrhynchum, Plantago arenaria W. K. und die gelbbraune langbehaarte Kochia scoparia im Jugendzustande, sowie der schöne Astragalus macrotropis wurden hier gesammelt. Alles das miserabel, nur ein Paar Zoll hoch, eine Statice, die jetzt schon blüht, Salsolen und Artemisien nur strichweise häufig. Man vergesse nicht dass diese Zeit für die hiesige Flora die Glanzperiode ist, Ende Mai ist alles mit Ausnahme von Salsola und Artemisien todt. Es gibt zwar an einigen wenigen Stellen Vertiefungen grösseren Umfangs, die infolge geringer Feuchtigkeit etwas besser bewachsen sind, aber nirgens sieht man den Versuch einen schwächlichen Rasen zu bilden, es fehlen sogar die Sand-Carices. In solchen Vertiefunger konnten Lepidium Draba und hier und da als Seltenheit Lep. perfoliatum existieren."

On comparing this with the accounts given by BASINER and Bonszczow, it will be seen that the difference between the Semi-desert and the true Clay-desert lies in the varying degree of dryness, correlated with a less or greater abundance of the spring-vegetation. Ephemeral species and springperennials occur in both places. Since the summer and au- 
tumn vegetation is similar in the two forms of desert there is no reason for distinguishing between "Clay-desert" and "Loess-steppe", as has been done by Antonow.

In the middle of May the Semi-desert is already beginning to turn yellow, and many of the spring-plants have even dispersed their seeds in April. Towards the end of May almost all the plants of non-xerophytic structure have withered or are withering rapidly, and the summer-plants make their appearance. Our illustration (fig. 4) shows the rolled-up withered yellow leaf-rosettes of Ferula Asa foetida, while many grey Artemisia bushes are not yet in bloom. The surface soil in this place was cracked by drying, but at a depth of 7 centimetres the loess was still dark with moisture. Thus it seems to be the dryness of the air rather than that of the soil which kills the spring-vegetation.

As June advances, any spring-plants left become so dry and brittle that they fall to pieces when touched. They soon disappear entirely and then the semi-desert becomes a true desert similar to the clay-desert proper. The two desert forms will therefore in what follows be treated together under the latter designation.

The surface in places is perfectly bare, but as a rule it is spotted over by scattered summer-plants. Generally only a single species or very few species occur together in each locality, different ones in the different places. The number of summer-plants is extremely limited, and a review of them is soon made.

Artemisiae often constitute the whole of the summervegetation; Bonszczow records $A$. fragrans and monogyna, but specimens I brought home were identified as $A$. herba alba. In any case the species are closely related to $A$. maritima: silver-white, aromatic undershrubs, strongly branched at the base. This mode of growth (a "Wermuth-Steppe") is seen in the illustration (fig. 4), and it may be uniform over large areas.

In other places Salsola rigida is the principal species. Its growth-form is between a shrub and an undershrub, half a metre high, dry and twiggy in appearance, and generally with many dead branches; its leaves are rigid and cylindri- 
cal. This is also the type of growth-form of Haloxylon Ammodendron, Salsola Arbuscula (figures 12 and 38), subaphylla and verrucosa, when these species grow in the clay-desert, but they have quite a different appearance when growing in the sand-desert. Low shrubs of leafless Ephedra alata, species of Calligonum and the succulent, salt-excreting Reaumuria oxiana are similar in type. Smirnowia turkestana and various species of Astragalus (A. Ammodendron, paucijugus, unifoliatus) are shrubs, sometimes a metre high, with inflated pods and poorly developed foliage. Smirnowia has small entire circular leaves, while the Astragalus species have leaflets which fall off quickly, leaving a persistent leaf-rachis.

In places where the ground-water is not too deep (e. g. near oases or rivers) the following are characteristic shrubs: Fresh green or greyish Tamarisks; the narrow-leaved Nitraria Schoberi comparatively rich in foliage; Halimodendron argenteum, a silver-leaved thorny leguminous bush with large inflated pods; Halostachys caspica and Halocnemum strobilaceum both bushes with Salicornia-like shoots; Prosopis Stephanianum a low mimosa-bush with pinnate leaves (probably occurs also in very dry places); Lycium ruthenicum; the broadleaved Capparis spinosa, and the spiny rosaceous Hulthemia berberifolia (I am not quite certain whether the last two vegetate during summer). There are also Frankenia hirsuta, Heliotropium dasycarpum, Statice suffruticosa, Alhagi Camelorum, all regarded as undershrubs and mostly found in the more favorable localities along with the perennials Peganum Harmala, Zygophyllum Eichwaldii, Pluchea caspica, Inula caspica, Dodartia orientalis (leafless) and Cressa cretica one of the Convolvulaceae well covered with a foliage of grey salt-excreting leaves.

As summer-plants of the dry clay-desert we should include the Chamaephytes ${ }^{1}$ ) Anabasis aphylla and salsa, Arthrophytum subulifolium, Nanophytum erinaceum and Noaea spinosissima, all leafless or thorny-leaved stunted undershrubs; also Anabasis eriopoda, a leafless Hemicryptophyte ${ }^{1}$ ), and finally a number of annuals.

1) See chapter 12. 
These last include Frankenia pulverulenta, Crozophora gracilis one of the low Euphorbiaceae with flat leaves densely coated with hairs, Carduus tenuiflorus, the fragrant Lachnophyllum gossypinum a Composite semi-rosette plant, and a few other species.

By far the greater majority of the annual summer plants belong to the Chenopodiaceae. They are almost all succulents and amongst them one can distinguish between various types. The first type is the Thorny Leaf-Succulents whose representatives (Salsola Kali, sogdiana, aperta, Androssowii) have spiny pointed leaves with water-storing tissue in the middle. The second type is the Thornless Leaf-Succulents (Salsola crassa, lanata, species of Halanthium, Halimocnemis macranthera, pilosa and villosa, Piptoptera turkestana, Suceda \&c.); these have succulent, often hairy cylindrical thornless leaves which still retain their function as the most important organs of assimilation. The third type, which I propose to call Bracteole-Succulents, are characterised by a distinct water-translocation (Burgerstein, Meschayeff) i. e. the plants sacrifice certain of their own organs to support the others, and in this case the foliage-leaves are drained of water and wither, while the plants concentrate their vigour on the inflorescence. Each floret of this is surrounded by three spoon-shaped bracteoles, namely the subtending leaf and two prophylls. These three organs are very succulent with their outer layers developed as green tissue, and they, with some assistance from the green stems, take the place of foliage leaves in assimilation. At the same time they protect the florets which sit squeezed in between them (see fig. 8 and 78).

The Bracteole-Succulents include Salsola incanescens, spissa and sclerantha, Halimocnemis Karelini.

These species are good examples of the type, and later in the summer they show scarcely a single foliage-leaf. The whole plant is beset with small globular bodies (the florets and their bracteoles), so that they have a characteristic appearance (fig. 8). Fleshy bracteoles around the flower are also frequent in the other types, but the appearance of the plants is 
very different when the foliage-leaves are present. Along with the Bracteole-Succulents may be mentioned Ceratocarpus are-

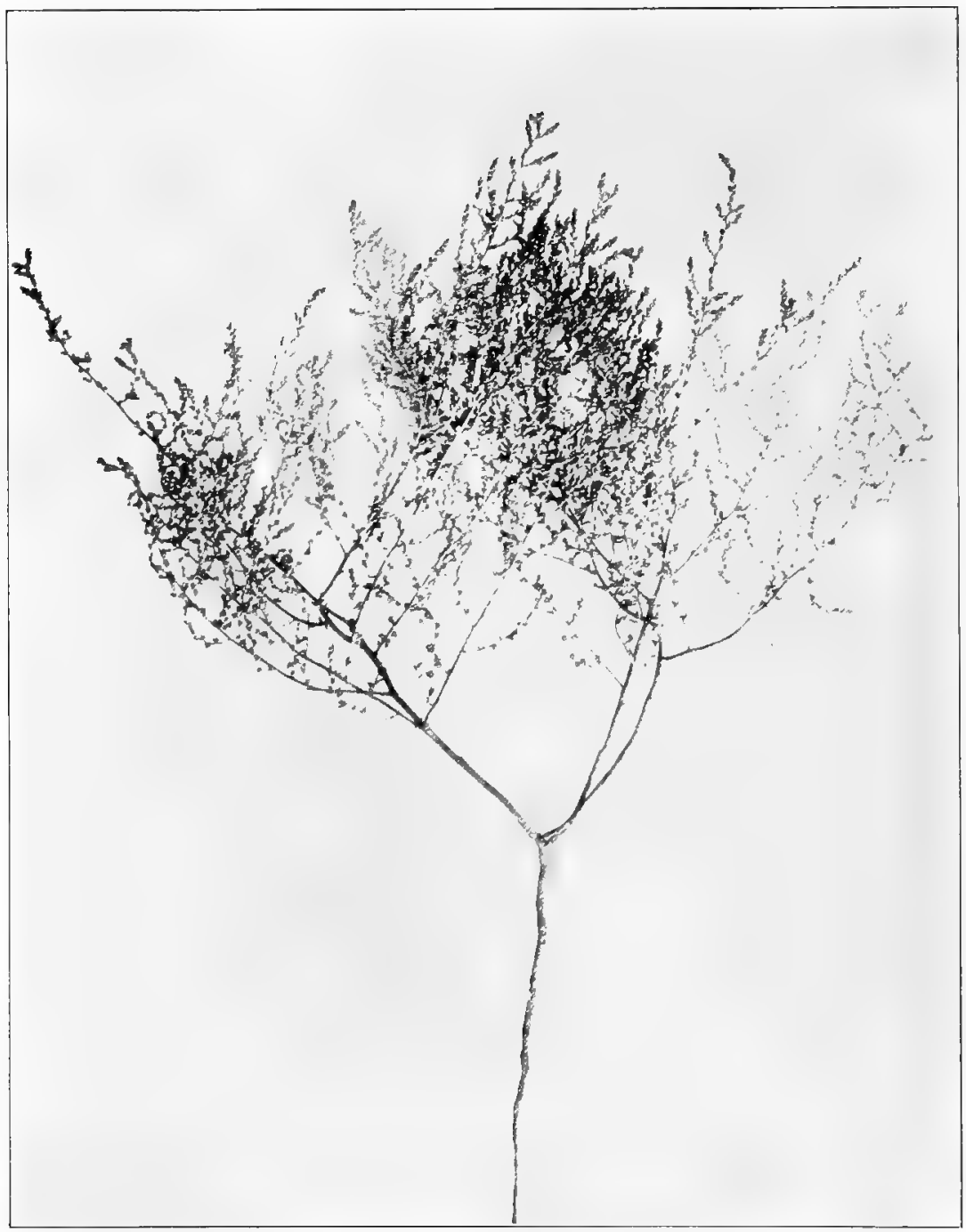

Fig. 8. Salsola spissa, an annual bracteole-succulent. June.

narius a plant of frequent occurrence many places in the clay-desert. Its flat, spiny non fleshy leaves lose all their parenchyma during the summer and become reduced to thorns, 
assimilation being taken over by the two connate spiny prophylls. The whole plant forms a spiny ball sometimes as large as 30 centimetres in diameter and of a grey colour. (See fig. 66).

Under the Summer-plants should also be grouped a red Lichen, Lecidea decipiens which in some places is common on the surface of the loess.

The structure of the Summer-phanerogams will be dealt with later (chap.13), when the different types of desert-plants are described. Here it is only necessary to give some of the more important features. The species which grow in the most favourable localities, where the ground-water is not too deep, are generally these with relatively the richest foliage: Tamarix, Halimodendron, Prosopis, Peganum, Zygophyllum, Pluchea, Inula, Alhagi have all distinctly green leaves and flat, with the exception of those of the Tamarix. None of them however have much foliage, nor does it cover the stems. In Alhagi only the oldest leaves persist, so that the upper shoots look like leafless spiny branches.

The plants of the dry desert may be grouped as follows: Succulents, Bracteole-Succulents or Leaf-Succulents, the last including Salsola Arbuscula, subaphylla, rigida and verrucosa, Reaumuria; leafless Stem-Succulents such as Haloxylon, Anabasis and Calligonum; deciduous shrubs like the species of Astragalus where other organs take over the work of assimilation; and finally plants with narrow leaf segments coated with hairs (Artemisia). All the species from the dry clay. desert belong to very xerophytic types, many have in addition a halophilous stamp (cylindrical assimilation-organs with aqueous tissue in the middle). In a case such as we are now considering it may be difficult, perhaps impossible, to distinguish between the xerophytic and the halophytic; which structural adaptations are due to desiccation and which to salinity of the ground-water can only be positively determined by experiments.

The usual aspect of the clay-desert in summer is a flat or slightly undulating surface, brown and dry, here and there with slight incrustations of salt, bare or scantily covered with scattered xerophilous plants which are herbs or small shrubs 
rarely higher than half a metre. The following are the most common: Saxaul, Salsola rigida, Artemisia, Halostachys and Halimodendron. - In depressions salt-deserts are found which are white with salt and produce their own particular vegetation closely related to that of the clay-deserts.

The Growth-Forms of the Clay-desert in Spring are Mesophytes, including Ephemeral plants and Perennials with short-lived aerial shoots; while in Summer (and of course also in spring) we have Xerophytes, some small shrubs and undershrubs, others perennials and long-lived annuals.

As emphasized above, the chief difference between Claydesert and Salt-desert is that the latter lacks the springaspect.

\section{CHAPTER 8}

\section{The Formation of the Stone-Deserts.}

AnTonow has recorded (see above p. 35) a formation which he calls "Promontory or Stone-Steppe", said to be characterised by a special flora. This formation, according to the nomenclature employed here, cannot be termed steppe but must be called desert. Whether it is different from the claydesert as regards its growth-forms I cannot determine with certainty because I have seen so little of the stone-desert. But it must be more correct to keep apart that which cannot with certainty be united, and therefore the stone-deserts will be considered here as a special formation.

The soil of the Stone-deserts is either rock, or gravel with stones, or a conglomerate. The layer of conglomerate, which is mentioned by AnTonow, is probably the ordinary tertiary conglomerate of stones cemented together by a loesslike clay. Conglomerates of this kind are very common in Turkestan (WALTHER) at the foot of the mountains and higher up in the mountain-valleys.

Where the cement is loess, what was stated about loess as a soil (p. 57) holds good here. But the presence of numer- 
ous stones makes the soil still more unfavourable to vegetation because the stones retard the absorption of water, reduce the capillarity and promote the conduction of heat in the soil. On the other hand they act favourably by reducing the evaporation from the surface (RAmanN).

The vegetation will only be described for the more important localities I have seen (all with one exception in summer).

At the base of Sultan Uis Dagh, an isolated group of mountains near Chiwa (see map), I examined a desert strewn with loose pieces of slate, and dotted here and there with rocks in situ. This desert evidently corresponds to what Volkens calls "Kieselwüste" WaLther and MiddendorfF call "Kieswüste". As in Egypt, so the desert here was almost devoid of plants. Only in depressions and where the number of stones seemed to be less, did various low undershrubs and dwarf-bushes occur: Salsola rigida, Artemisia herba alba, Capparis spinosa, Atraphaxis compacta and Haloxylon Ammodendron, the latter being low shrubs about half a metre high. Less conspicuous were Stellera Lessertii, Convolvulus fruticosus, along with Halimocnemis macranthera and Anabasis eriopoda, two pronounced halophytes. In Ferghana, MiddenDORFF found about one plant per square foot (1. c. p. 21) on the stone-desert.

The mountain itself, Sultan Uis Dagh (Sultan Baba-ne Dagh-e) consists of nearly vertical strata of a greenish claymica-slate, often impregnated with quartz. The surface in many places is covered by disintegrated matter, fine yellow clay and pieces of slate with a shiny tawny wealhered surface. Everywhere was very dry, even the deserted beds of several streams, which were no richer in vegetation than the rest. The following plants were found scattered widely about: Atraphaxis compacta, Salsola Arbuscula, Salsola rigida, Capparis spinosa, Artemisia sp., all dwarf or undershrubs, also two withered annuals, a Composite and Lepidium persicum (?) and low trees of Saxaul less than a metre high.

At Kis-Kalá, a mountain with a ruined castle, on the right bank of the Amu Darya more to the south, I saw a desert where the soil consisted of very stony gravel and sand. 
On this soil Reaumuria fruticosa was characteristic, a low bush with closely set minute leaves covered with salt-crystals. Some other species occurred on some small dunes, but these only appeared one at a time on the stony soil. (See chap. 11). The following Lichens were found on stones: Sarcogyne perilenca, Placodium Paulsenii, Acarospora interrupta. At Dana Sher Kalá not far from this place, there was a stony gravel plain with very scattered small bushes of Salsola rigida behind which hillocks of sand had drifted; this was the only species.

At Ak-Yar (also on the Amu Darya) there is an undulating plain of loess with splintered pieces of clay-slate and knolls of the same rock in situ. The following plants were scattered about, approximately 3 paces apart: Salsola rigida and Arbuscula, Reaumuria oxiana, Saxaul and rarely Lycium ruthenicum; all were stunted shrubs less than half a metre high. The herbaceous species included Salsola carinata, Suaeda $s p$. and Lepidium obtusum. Depressions with a stiff fissured clay were devoid of plants or bore only a few halophytes (Halocnemum, Halimocnemis).

At Pitnjak there was a gravel plain with Peganum Harmala, Convolvulus eremophilus and Anabasis salsa, very scattered.

At Kisel-Yi also situated south of Chiwa, we found hard clay hills with many white stones, quite bare except in the depressions where there were scattered plants of Halimocnemis macranthera (an annual summer-plant with thick leaves) Salsola rigida, low Saxaul bushes, Artemisia, Alhagi Camelorum. The last alone crept up the hillside here and there.

Near Andidshan (Ferghana), very stony loess about a foot thick formed a layer over stones and gravel. Here grew (May $27^{\text {th }}$ ) Tamarisks not more than a metre high, Alhagi Camelorum, Crambe orientalis (?), the thorny and silverhaired undershrub Convolvulus fruticosus, Echinops sp., Astragalus $s p$., etc.; the visit to this locality was a rery brief one.

Other localities were observed where the soil was rock in situ or stone, but as these were covered by sand, partly shifting, and as it seemed to me that there the sand was mainly responsible for the character of the vegetation, they are not included here. 
These observations indicate that the vegelation of the Stone-deserts is mainly characterised by xerophytic stunted shrubs and undershrubs. Whether spring-plants occur there, I cannot say.

The following are species found only in the Stone-desert: Convolvulus fruticosus, Stellera Lessertii, Reaumuria fruticosa and Atraphaxis compacta, all dwarf-bushes or undershrubs with small and flat leaves. The following seem to be common in the Stone-desert, though they also occur in other formations: Reaumuria oxiana, Salsola rigida, (one of the most frequent) Arthrophytum subulifolium, Artemisia sp., Convolvulus eremophilus, Capparis spinosa.

\section{CHAPTER 9}

\section{The Formation of the Sand-Deserts.}

The soil of this formation is sand, at least on the surface. The sand varies in origin and age as stated in chap. $2^{1}$ ), but these differences do not seem to play any essential part with respect to the vegetation (Konshinsky p. 8). The different aspects presented by the sand are of greater interest to the botanist. These have been described by Mushketow, Radde and Semenow, and the following survey of the various sandlandscapes is based on the observations of these authors.

1. Barchans, crescent-shaped, dirty yellowish or fawncoloured dunes of inland sand. Musketow states that they are generally $30-40$ feet (ab. 9-12 metres) high, and may attain a height of a hundred feet (ab. 30 metres); $\mathrm{SE}_{E}$ MENow gives 40 metres but I have rarely seen any higher than 10 metres and RADDE gives 30-35 feet (ab. 9-10 metres) as the maximum. The sand-grains are rather small. RADDE (1899, p. 16) gives $0.2-0.3 \mathrm{~m}$. $\mathrm{m}$. as the average size for Barchan-sand and Sand-steppe sand from Amu Darya and Kara

1) See moreover Romanowski p. 52. 
Kum, and at Dshideli Mushketow found Barchan-sand with grains not exceeding 0,1 millimetre.

The sand always, in the Barchans and elsewhere, consists of quartz. A little mica is found in it, also varying quantities of clay (up to $30-40$ per ct. on barchans in dry rivervalleys), and frequently iron, small quantities of gypsum, calcite, etc. (RADDE 1899 p. 16).

The form of the Barchans has already been described (p. 7). RADDE's comparison of a barchan-landscape to a frozen stormy sea is a good simile except that waves are not regularly crescent-shaped. Standing on one of the summits and looking towards the north so that the concave sides of the barchans are turned towards one, this imposing waste is most awe-inspiring. As far as the eye can reach vawe rises behind wave, crest behind crest. The barchans arise irregularly, often several in a group, their flanks blending so that the sharp crestlines undulate up and down, in and out. Even a gentle breeze raises the fine sand from every crest, and the brownish sandsmoke from the bare dune-summits adds an additional weirdness to the waste landscape.

As the prevailing winds are northern or north-easterly the sand migrates towards the south and west and crosses the Amu Darya. This will be further dealt with in chap. 11.

2. Hummock-Desert, Hummock-Sand (in RADDE "Hügelsand", in Semenow "désert de sable mamelonnée"). Rounded hills, quite low or fairly high, up to about 10 metres, with basin-shaped hollows between them, and with no windward and lee side. They are stationary dunes with a comparatively rich vegetation.

3. Desert of the sand-plains ("Sand-steppe", "steppes sablonneuses"), flat or somewhat undulating areas of sedentary sand.

4. Dune-chain sands ("Ketten-, Reihen-, Wall-, oder Streifensand" of RADDE, "déserts de sables en sillons" of SEmenow). Parallel sand-hills formed by the grey or white sand of present or past times. Between the chains are valleys, ab. 45-200 metres $(150-700$ feet) wide, the soil of which is bare clay (Takyr). The valleys are crossed by lower dunes which run transversely to the main dune-chains. Dune-chain sands 
are mostly found in the northwestern part of the lowland. They are comparatively well covered with switch-like desertshrubs, Carex physodes, etc., and the sand-drift is of no great importance.

5. "Dunes", or recent accumulations of shifting greyish or white sea-sand occurring mostly along the coast of the Caspian, and generally arranged in chains which follow the direction of the wind.

Dune-chain sands and recent dunes, both formed by white or grey sea-sand, l have not seen, hence they are here left out of consideration, and only the different forms of inland-sand are dealt with.

The first point to be considered is sand as a soil for plants in comparison with clay.

In dry countries sand is, in some respects, more favourable to vegetation than clay. ${ }^{1}$ ) Water is quickly absorbed so that it has no time to evaporate. Less water will evaporate from a rough, coarse-grained surface of sand than from an even, fine-grained surface of clay. Because of the slight waterholding capacity of sand, the water is carried to greater depths, whence it does not rise easily to the surface owing to the poor capillarity of sand. The evaporation-surface of the water will therefore be situated down in the earth where it is protected by the overlying drier layers of soil (comp. Livingston 1906). Deep sand is a soil which suits plants with very long roots. The switch-shaped trees and shrubs generally occur here.

Though sand can absorb much less water than clay $(14,3$ per ct. of dry weight, loess 59,3 per ct. according to Clements, p. 34), almost all the water absorbed is available for the plants: "Echard" is only 0,3 per ct., "Chresard" 14 per ct. (comp. above p. 58). The figures vary of course somewhat according to the properties of the sand, especially the size of the grains (Livingston 1905), but I am not aware

1) Fitting (p. 251) also finds that the sand-plants of the Sahara have a lower osmotic pressure than the plants of the stone-deserts even when they belong to the same species. 
that investigations on these conditions have been made in Transcaspia.

Where the sand forms a stratum over the loess it becomes of special importance. The water from precipitation will be let down through the sand into the upper layers of loess, whence it cannot evaporate because protected by sand, and yet it is still available for the roots of plants, if the sand is not too deep. The natural conditions are here specially favourable, and it is on sand over loess that the most luxuriant desert-vegetation is found during summer (see chap. 11). These conditions are now successfully imitated by man. In the dry parts of North America "dry farming" is conducted, the principle being that the subsoil, by the aid of special implements, is always kept solid, so that it can raise the water, while the surface-soil is kept loose so that it can protect the subsoil and itself lose the least possible amount of water through evaporation (see Matenaers).

Though sand is more easily leached than clay, the under ground water in the sand-desert is almost always salt, and gypsum crystals frequently occur in quantity at a depth of $1 / 2-1$ metre (PaLezkis p. 36). Many of the sand-plants are also halophytic in structure.

Where no water is present the desert-sand is an exceedingly hot soil, all the more as it is not white but brown. The expedition recorded $53{ }^{\circ} \mathrm{C}$. on a summer's day just below the surface, but even higher temperatures might certainly be found.

Sand is more unfavourable to vegetation than clay, in this respect, that the sand is moveable. Sometimes the roots of the plants are laid bare, sometimes aerial shoots are buried, either of which conditions may kill the plant. The drifting sand-grains may also bruise young or unprotected plant-tissues and in this way cause injury. This has already received attention in the literature on European dunes, e. g. WARMING 1909.

The following description of the vegetation of the Sanddesert deals first with the more shifting deserts, afterwards with the stationary types. The desert is described in its 
summer-aspect; then in its spring-aspect, which greatly reminds one of that of the clay-desert.

In the more shifting deserts there are areas with nothing of interest to the botanist. Hills and valleys of sand, not even a stone, nothing but sand. This is sorted out by the wind, the coarser and darker sand covers the gentle slopes of the windward side and the crests of the wind-billows, while the finer and lighter sand is found on the stecper lee side and in the valleys. These variations in shade increase the relief of the surface.

The first pioneer of the vegetation is "Selin", Aristida pennata Trin. ${ }^{1}$ ), so aptly called by AnTonow the Conqueror of the Sand-desert.

Aristida pennata takes first place as a sand fighter. It grows quickly, and gives off many roots, many leaves, many branches, while its internal structure enables it to endure drought and sand-drift. It is more fully described later (chap. 13), but features of its biology may be indicated now.

After germination it forms a number of basal scale-leaves through whose sheaths the fibrous roots break out. The foliage leaves follow on short internodes so that their sheaths form a "Tunic" (HACKEL), the one sheath lies over the other, with only a short apex free, so that the expanded leaf-blades are close-set one over another. In the axils of the scale-leaves lateral shoots quickly appear covered by their "tunics". The young plant thus forms a close tuft with the oldest shoots in the middle (fig. 9), and as the tufts grow older they become coarse leafy tussocks half a metre or more in diameter. When the sand drifts over, the plant pushes upwards with longer internodes, and new lateral. shoots with basal roots are continually being formed. so that the plant is fixed in the sand almost right up to the surface. The lateral shoots

1) This plant has been named at different times $A$. pungens Desf., $A$, pungens var. pennata, $A$. pennata and sometimes it has been regarded as two species $A$. pennata and $A$. pungens. It is certainly closely related to the Sahara form $A$, pungens, being distinguished from it mainly by its more slender growth and by longer branches of the panicle. I do not think there is any reason for calling specimens with shorter panicle-branches $A$. pungens. The Transcaspian specimens are certainly all the same species 


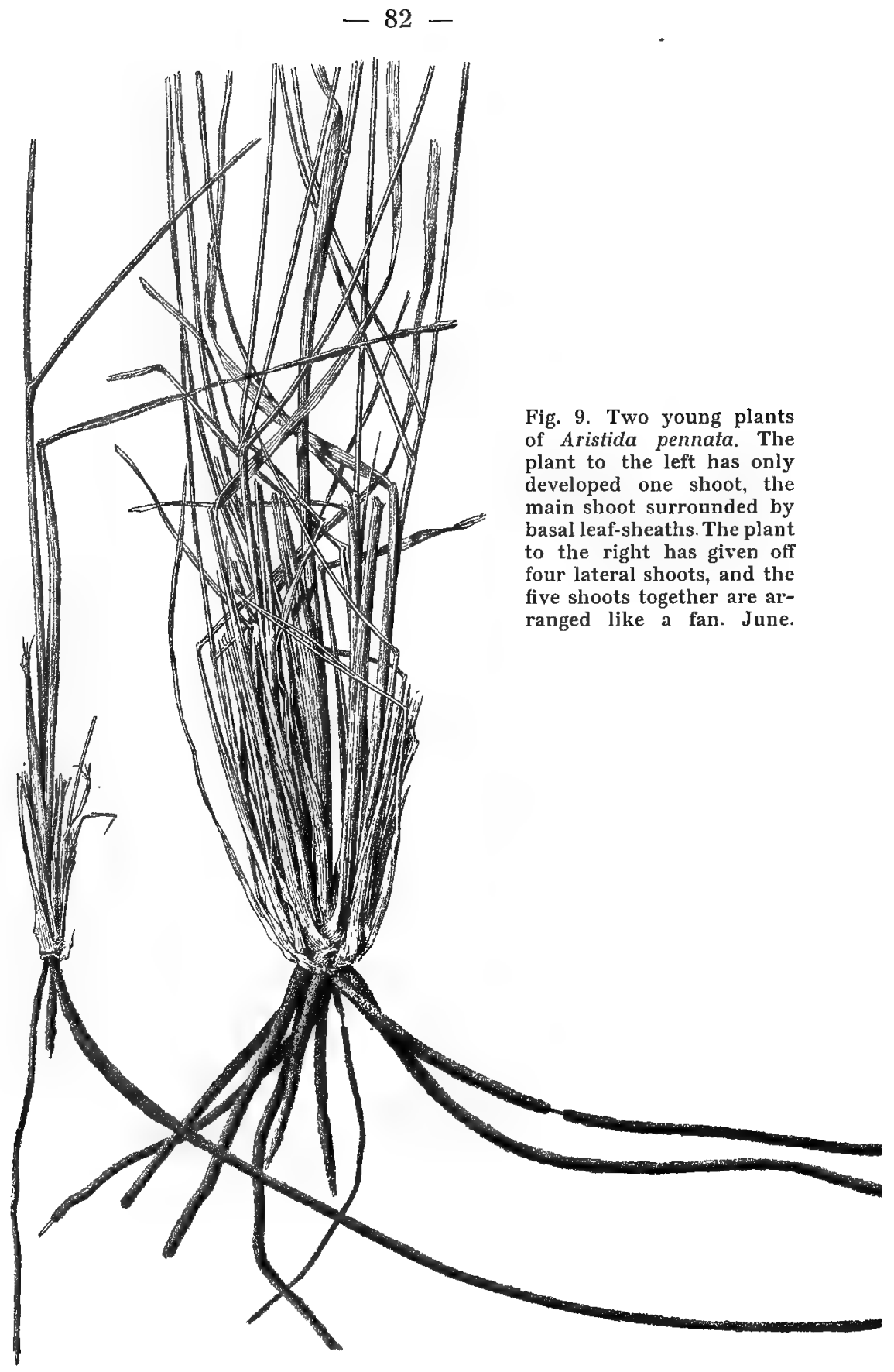


continue to grow and to struggle against the sand after the older main shoots have flowered. Horizontal runners are not formed, so far as I know. According to Palezku, Aristida forms two kinds of roots, long horizontal anchoring roots, and shorter perpendicular absorbing roots. The roots are protected by a "sand-stocking" or cover in which the other root-tissues are loosely enclosed. The leaves are able to roll up like those of Psamma, and have green tissue on the protected upper surface.

In the shifting sand-desert, all other vegetation is dependent on the presence of Aristida pennata.

This plant is not merely a sand-binder, but plays an even more important part because its dense tufts are practically the only place, where seeds of other plants can secure a roothold. Palezkn has drawn attention to this fact, and I have frequently observed, that the fruits of the switch-bushes find a resting place in the Aristida tufts where they are retained amongst the leaves and shoots and are frequently covered by sand. These fruits easily roll about in the wind so that they would hardly ever germinate in the shifting desert if it were not for the tufts. In more stable parts, the conditions are more favourable and there is generally sufficient vegetation for the fruits to establish themselves.

The plants which come next after Aristida, and perhaps some of the annuals, are the switch-bushes, a very characteristic type. In the sand-desert the most hardy is the Sand Acacia (Ammodendron Conollyi (fig. 10) and Karelini). It occurs as slender trees or low shrubs standing hundreds of metres apart. Grey in colour, it has small narrow leaves thickly coated with silky hairs, and light passes through the crown so that only a slight shade is cast (see Lipsky 1911 tab. 1). In the valleys between the barchans it may form a tree with a trunk and elegant hanging branches, but sometimes where the barchan has swept over the trees only the tops of tbe crowns are seen protruding above the sand. The strength of the Sand Acacia lies in its height, its long roots (19 metres, Palezkru) and its small leaves.

If this plant can hold its own and produce seeds from the butter-coloured one-seeded samaras which ripen in May, 


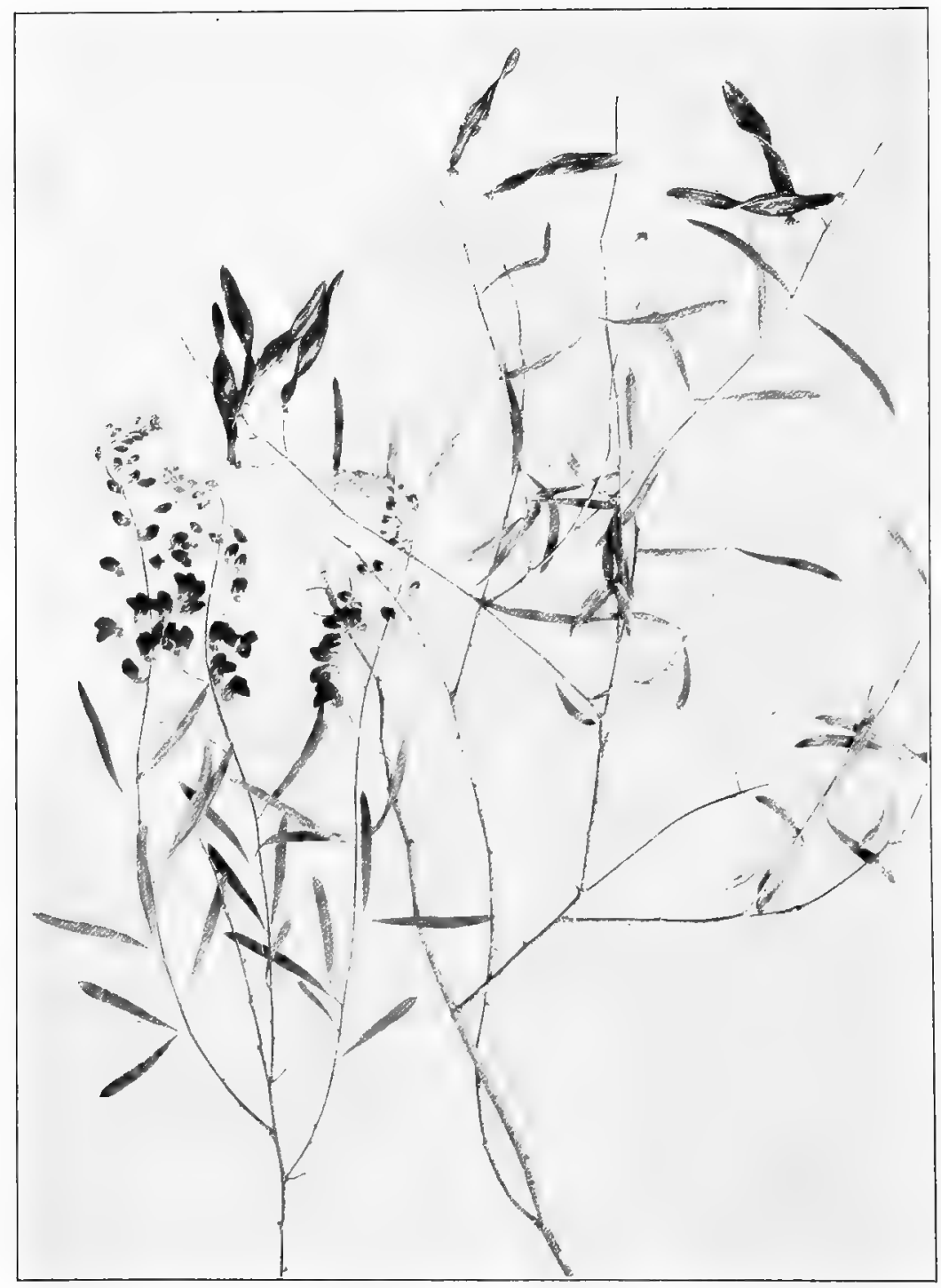

Fig. 10. Ammodendron Conollyi. A flowering branch (on the left) and a fruiting branch (June). The dead axes of the inflorescence complete the yeargrowth of this shoot. 


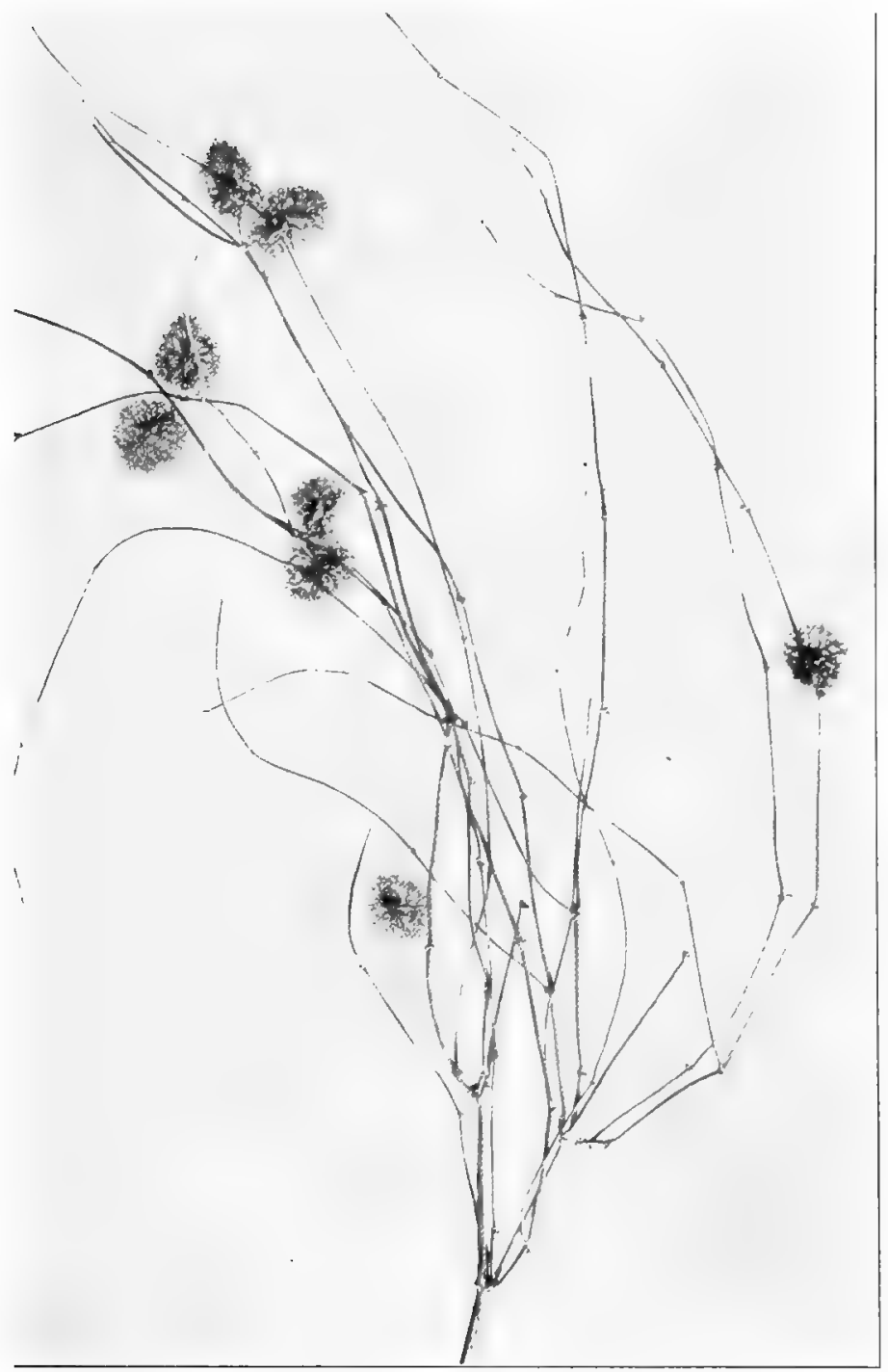

Illigonum Caput Medusae. Fruit-bearing branch, which has lost some of the fruits. End of May. 
and if these are allowed to germinate, then the vegetation (if such a word can be employed) becomes by degrees somewhat denser and other species appear. First and foremost come other switch-bushes: Calligonum, Salsola Arbuscula and subaphylla, Eremosparton, Saxaul and sometimes Ephedra alata. A desert covered with these shrubs is a most characteristic sight; to describe it the following lines by Konshinsky l. c. p. 4) may be cited:

"They are bushes or small trees, from 1 to 4 or 5 Arshins high $\left(0,7-2,8-3,5\right.$ metres $\left.{ }^{1}\right)$, very characteristic both in their appearance and in their mode of growth. Their stems as a rule are short, bent and often very irregularly shaped on account of deep and long furrows. The branches are generally white or greyish, the leaves narrow and greenish-grey. Frequently there are no leaves at all, and they are replaced by the young branches which contain chlorophyll. Most of these ligneous plants grow very slowly and have an exceedingly hard but brittle wood, this is especially the case with Saxaul. These low trees stand widely apart, they do not cast the least shade, so that the soil under them is almost as dry and unfertile, almost as scorched by the rays of the sun as if there were no trees at all.

No comparison is possible between this bushland and forest or scrub in temperate areas, and on the whole none of the expressions used in literature or science are adequate to describe them. They form a special type of vegetation, so unique and characteristic that I cannot believe it will ever fade from the memory af any one who has had a single opportunity of seeing it."

Only two of the switch-like trees and bushes have a luxuriant green appearance. They are Salsola Arbuscula and S. subaphylla (figures 12 and 13), especially the former. This plant has already been described (chap. 6) as frequent in dry clay-deserts, where it is a dry, stiff, prickly bush about half a metre high with sholt hard shoots and stiff plump leaves.

1) This description deals with vegetation on more stable soil where the trees and bushes are lower.

O. P. 


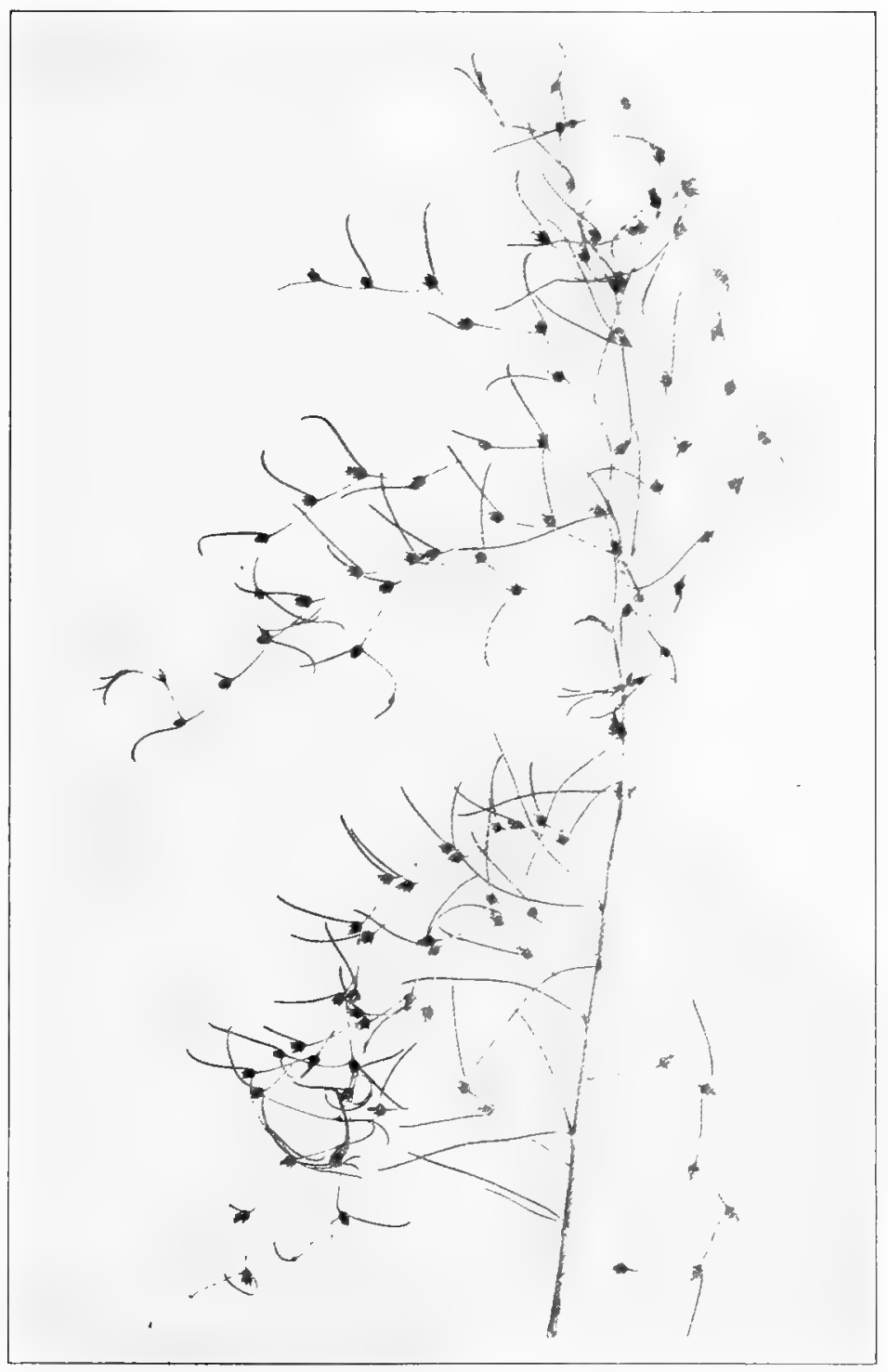

Fig. 12. Salsola Arbuscula var. longifolia (The Sand-desert form). Part of a year's shoot with flowering branches. September. 
But when it grows in the moving-sand desert, it becomes a small tree, more than 4 metres high, and with long, pliant shoots and leaves (comp. fig. 12 and fig. 38). The foliage is comparatively rich; it is a green tree sufficiently dense to cast a shade.

The plant is very hardy and can endure being covered by sand, a process which only hastens its already precocious growth, and (according to PalezkiJ) roots are formed from the buried parts of the stem. He also states that he has measured roots 15 metres in length, many of them horizontal. Whether suckers are formed from them I do not know. I have seen a tree from which the sand had been blown away, so that it had fallen and lay on the slope of a dune with some of the branches buried. The plant, however, was perfectly fresh, still fixed by its roots and it had given off new roots from the buried branches.

Salsola subaphylla is somewhat similar in appearance, but has coarser and less dense foliage and neither in height nor age does it come up the other species. Somewhat saline soil is the most favourable for this plant.

Both species blossom freely in the late summer and in September they bear large clusters of broad-winged perianths carrying the fruits.

These two species, particularly the former, play an important part in the operations for binding the sand along the railways.

Calligonum (figures 11,27, 28) and Eremosparton aphyllum (figures 23, 24) are both leafless i. e. the leaves are reduced to quite small scales, and both are shrubs or small trees attaining a height of about 4 metres. They have long roots (PALEZKIJ measured roots of 4,25 metres in a year-old specimen of Calligonum Caput Medusae) and both plants can form root-suckers.

They are both sand-plants - Calligonum, however, not exclusively - and they endure the sand-drift very well. Of the many species of Calligonum (see list in chap. 12), C. Caput Medusae is the most important. It flowers in May or June and already in June one finds the curious globular reddish fruits set along the slender twigs. The fruits are achenes 
twisted like a screw and with several rows of long manypronged bristles spread out in every direction and quite sliff when ripe. The fruit thus appears as a kernel set in the midst of a globular transparent meshwork, the diameter of the whole being $2-3 \mathrm{~cm}$. (See fig. 28). These fruits are exceedingly mobile and roll away at the slightest breath of wind.

The fruit of Eremosparton is a one-seeded woolly-haired pod, one centimetre long. The red blossoms open in May or June and form small racemes, but only the earlier blossoms set fruit as the later ones are shrivelled up by the heat.

Saxaul or Sasák (Haloxylon Ammodendron) (fig. 14) only thrives well where the sand has a subsoil of clay or limestone. Under favourable conditions it may become a tree of 7 metres. Often, however, it is a much-branched shrub. As the growth is slow, this species does not stand sand-drift very well, and the young, soft, leafless shoots are also bruised and damaged by the sand-grains ${ }^{1}$ ).

These switch trees and bushes have the following characters in common (other details of morphology and internal structure are given in chap. 13). They are small trees or bushes; the Sand-Acacia and Saxaul occasionally become larger trees (8 metres).

All of them have their leaves much reduced. Ammodendron has flat leaves, but they are small and thickly coated with silky hairs. The Salsola species have cylindrical chenopodiaceous leaves with central water-tissue. In Calligonum, Eremosparton and Haloxylon the leaves are reduced to small scales, and the assimilatory functions are performed by the stems alone.

The first-year shoots are frequently branched, sometimes

1) Saxaul is said to form vast bushlands ("forest", comp. Lipsky above p. 28) east of Lake Aral (Wladimirskaja). The trees here are said to attain a height of 16-18 feet and have a thick tap-root. Saxaul often occurs here together with rushes and is supposed to stand in a certain relation to the Syr Darya (Jaxartes) inundation area. "The Saxaul forests everywhere begin as a low thorny scrub along with Tamarisks, then they become bushlands and finally forests.' (MrDdendonfF p. 308). - Lipsky (1911 p. 14) denies that the growth of Saxaul is necessarily slow. 


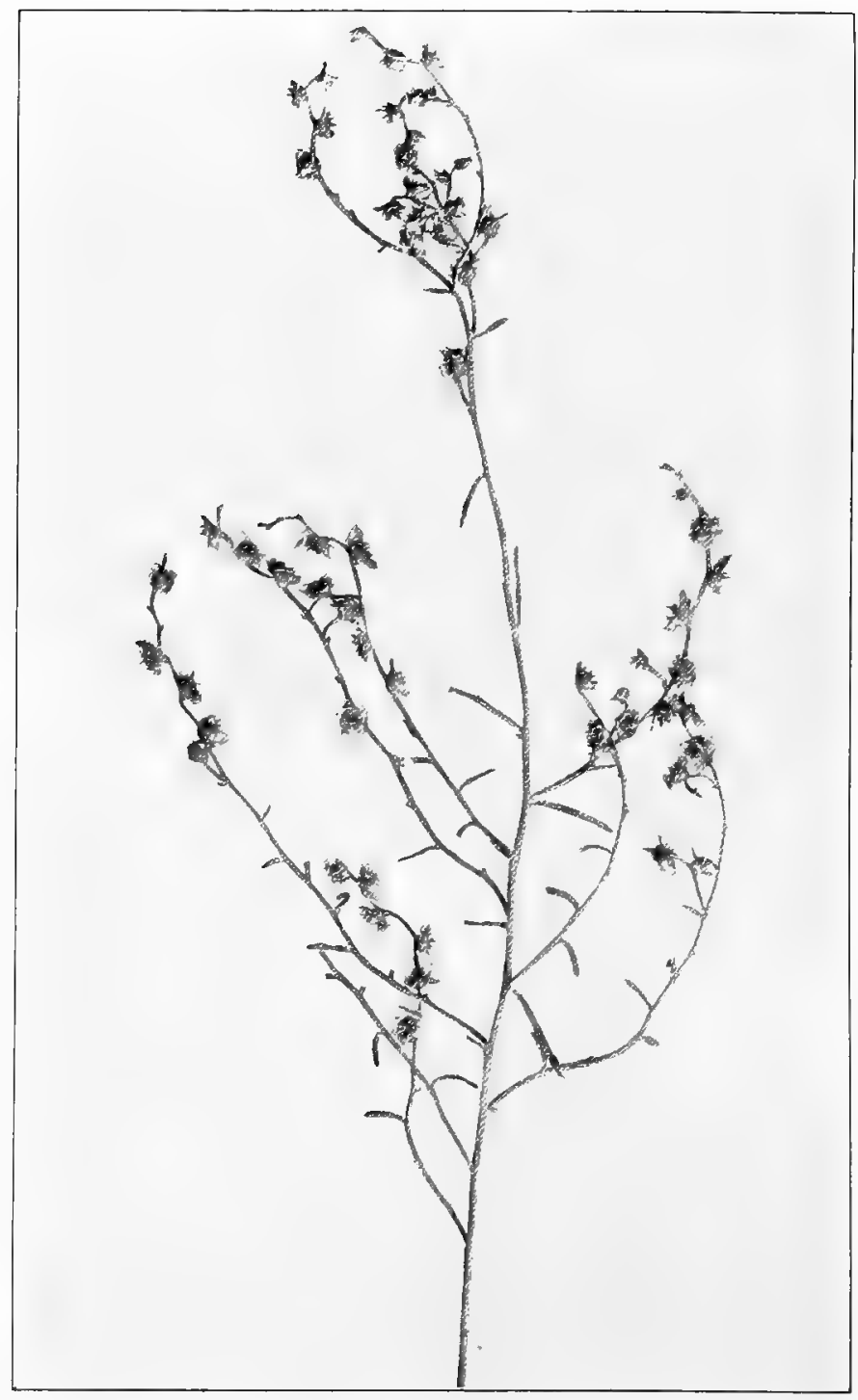

Fig. 13. Salsola subaphylla. Part of a year's shoot with branches. The fruits are ripening. September. 


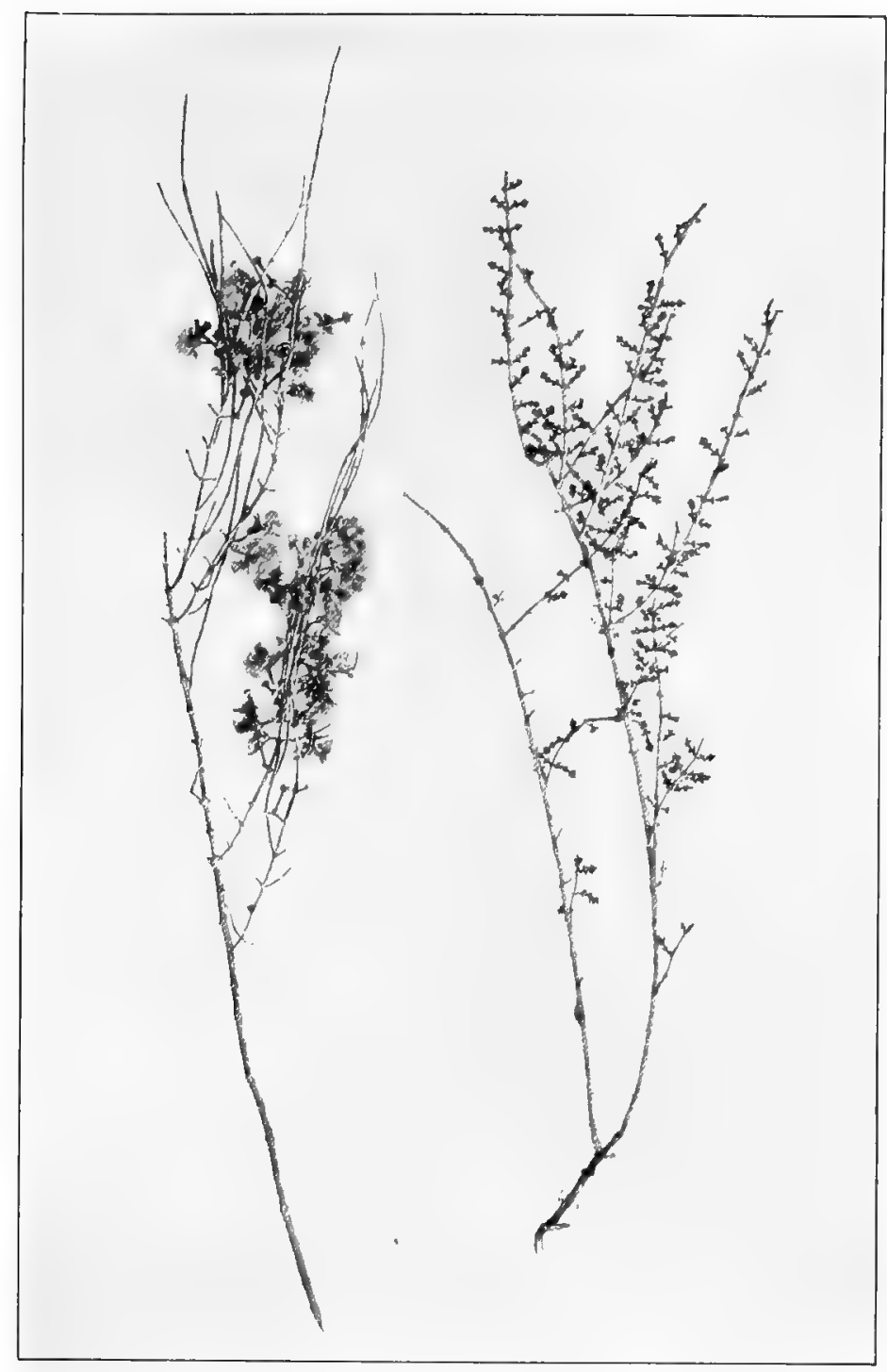

Fig. 14. Haloxylon Ammodendron. Fruit-bearing branch and flowering branch. November and April. (Afghanistan). 
bearing several series of branches. The vegetative branches are annual like the floral ones, and may therefore biologically be regarded as leaves which fall off at the end of the vegetative period.

The perennial as well as the annual branches are often closely bunched together owing to the formation of new branches year after year at the same place. The younger branch-tips are often pendant and wave in the wind (Ammodendron, Haloxylon, Salsola Arbuscula).

They have all long roots. The fruits in every case contain one or at most a few seeds, and are so formed that they fly or roll easily before the wind, hence one finds them massed together in sheltered places.

To the bushes and trees given above for the Sand-desert, the following may be added which like Saxaul are rather plants of clay soils and do not thrive so well on pure deep sand: Smirnowia turkestana, Astragalus Ammodendron, paucijugus, unifoliatus, Ephedra alata, Tamarisks and probably others.

The switch-shaped trees and bushes (and Aristida) are however rarely the only living plants in the Sand-desert. Between the dunes where there is a certain amount of shelter, the soil in many places is sufficiently stabilised for the growth of hardy herbaceous plants. These are not places where there is clay soil between the dunes - such belong to the formation of the clay-deserl,-- but where there is sandy soil somewhat sheltered and therefore not shifting. Here grow a number of annual and perennial herbs which are more xerophytic and less halophytic in type than the clay-plants. They occur scattered about, and frequently they have a hard struggle for existence where the sand blows away or drifts over them.

One of the most frequent is Heliotropium Radula. This like $H$. sogdianum which also occurs, has a thin horizontal rhizome, sometimes of considerable length $(2,5$ metres and more), and lying close under the sand-surface; it puts forth numerous aerial shoots, which generally form hairy leafrosettes arranged in a row, similar to the roseltes of our Carex arenaria. (Fig. 63). Long-jointed shoots bearing inflorescences 
may also be found. The rhizomes are sometimes laid bare, one I saw being 132 centimetres long and only attached at one end, but still living. When the plant is buried by sand, a new aerial shoot is formed from an axillary bud of one of the higher leaves and terminates in a rosette on the sand. (Fig. 22). But these shools do not endure the sand-drift very well, and I have seen specimens buried again which were dead. The long rhizomes may be regarded as a means of defence; with the aerial shoots widely distributed there is always a possibility that some of them may escape destruction by the sand-drift. The hairs on the leaves also probably give some protection against bruising by sand.

Living in the Sand-deserts are also a number of plants of the type of Salsola Kali, i. e. spiny hard plants with a limited amount of assimilation tissue. These include both annuals and perennials, mostly the former. The following are the most noteworthy amongst those I have seen.

Horaninowia ulicina (fig. 70) is an annual. From the summit of the long straight lignified root, there arise a number of stems $20-30$ centimetres in length, which lie on the surface of the ground. The leaves are opposite, acicular and spiny, and bear in their axils dwarf-shoots or long-shoots. The dwarf-shoots appear as bunches of thorns (see figure 70) and when long-shoots are formed they bear the groups of thorns. Should this plant be covered by sand, the dwarfshoots elongate and become long-shoots, which struggle to reach the light, while the main-shoots may be seen to change their direction and to grow obliquely upwards, until they again emerge above the surface.

In more favourable places the species has longer leaves and is more erect (var. longifolia). The leaves and young stems are coated with stiff, viscous hairs amongst which sandgrains are often retained; these hairs must limit the mechanical effects of the sand-drift.

Agriophyllum minus (fig. 72) is also an annual. Large specimens become strongly branched. The leaves are grasslike flat, dry, multicostate, stellate-haired and thorny-pointed; all bear dwarf-shoots like bunches of thorns, or long-shoots which carry the thorny shoots. The leaves more especially 
the lower ones die early, but the axillary shoots remain active (Translocation of water).

Closely related to the last is Agriophyllum latifolium (fig. 74). The chief difference is that this plant has broad, opposite ovate or almost circular leaves with long stalks, and the primary vein terminates in a thorn. The upper leaves all show transitions towards the narrow, grass-like leaf of the preceding species. All the leaves support long-lived bunches of thorns as in the former species.

Salsola Kali also belongs to this type together with the allied species, S. sogdiana (fig. 76) and aperta, also Cornulaca Korschinskyi (fig. 68) and Arthrophytum subulifolium, all thornyleaved, stiff, branched plants, and annuals except the last which is an undershrub. Acanthophyllum elatius, an undershrub with prostrate branches and stiff, thorny leaves, should also be included here. Ceratocarpus arenarius (fig. 66), frequently a clay-plant, may also be found on sand; it is exceedingly branched and thorny and is generally globular in shape. The parenchyma dies away, but the midrib remains as a long, pointed thorn (comp. above p. 72 and chapt. 13).

Convolvulus erinaceus, an undershrub very abundant locally in the Sand-desert, also assumes the globular form. In spring it has true narrow foliage leaves at the base, but later on only scales are present and the work of assimilation is entirely carried on by the branches. The first-year shoots are strongly branched and geniculate at the nodes, and their branches of the later $(1-2-3)$ sequences are thorns which bear a single flower. The plant forms a leafless thorny ball, it can attain a height of 40 centimetres and has very long roots. I have seen pieces several metres long, laid bare above the sand, and although only fixed at one end they were giving off fresh shoots. If the plant is buried the upper branches grow upwards through the sand.

Convolvalus eremophilus has a similar structure, but it is less strongly branched and less thorny.

Euphorbia cheirolepis an annual plant with small, bright green and glossy, spathulate and spiny toothed leaves belongs to another type. The same green colour distinguishes the vigorous, broad-leaved and very thorny Cousinia annua which 
attracts attention by its glossy snow-white stems. This plant I found in a deep valley amongst the dunes on a shifting sand-desert almost devoid of vegetation; there were only a few specimens and only in this particular valley. This illustrates the very scattered occurrence of the various species; one must examine a great number of localities before a thorough knowledge of the flora of the desert is acquired. Each locality presents only a few species of trees, shrubs or herbs. Other examples of this will be referred to in chap. 11. It will be seen from the above description that the flora of the shifting Sand-desert is extremely poor. Looking over the desert from the top of a barchan, the eye is attracted by the scattered rough tussocks of Aristida and the switch or brushlike dwarf trees and shrubs, standing widely apart, particularly Ammodendron and Calligonum the most frequent and most enduring.

Only on closer examination does one find the herbaceous plants which hide in the valleys. These plants, already referred to, are ill-adapted to withstand sand-covering and are often smothered. But they endure desiccation, heat and the tear and wear of the drifting sand. This tear and wear is perhaps the reason why the plants of the more stable sand-desert are very rarely seen in the true shifting desert.

From the shifting sand-desert where the barchans hold their sway, we turn to a more stable type of sand-desert, the Hummock-desert (see p. 78), which RADDE compared to a dead sea with a swell on, and which he regards as a transitional form between the barchans and the flat deserts. The sand hills are round and generally rather low, Radde states from a few feet up to $4-5$ fathoms, i. e. about 10 metres at the most, which is, however, a considerable height. Where the hills are grouped closely together, the valleys between them are basin-shaped. Smaller crescent-shaped barchans may be present so that the sand-drift is not everywhere perfectly stabilised. The movement must however be slight in many parts, as indicated by RADDE finding on the hilltops a lichen (Urceolaria indurata Wain.), a thin black and white coating over the surface of the sand.

The vegetation consists partly of the same species as on 
the barchans, but they are differently developed, the trees and shrubs being weaker while the herbs are stronger. Another part of the vegetation consists of more exacting species including halophytes which grow in the valleys.

I look on the vegetation of the Hummock-desert as a sub-formation of the formation of the Sand-desert.

The vegetation is richer than on the barchans. The desert switch-plants are closer together than on the barchans, but they are smaller and generally take the form of shrubs, not trees. In such a Hummock-desert I found the average height of the bushes to be 2 metres and the distance between them from 7 to 20 metres. The conditions for germination are better, hence the greater density; on the other hand that acceleration of growth brought about by drifting sand is lacking, hence the smaller size.

The Sand Acacia (Ammodendron) is rarer here, while of general occurrence are Salsola Arbuscula and several species of Calligonum (these are difficult to determine without fruits). Amongst other plants present are Saxaul, Eremosparton, Smirnowia, bushes of Astragalus, and Nitraria Schoberi (which sometimes causes the formation of small dunes); Lycium sp. and Reaumuria oxiana are both halophytic bushes, generally occurring on clay, but also found in the lower parts of the sand-desert. Tamarisks occur on peculiar knolls of stratified sand which originate as follows: every year the Tamarisks cast numerous small twigs and flower-stalks over which a layer of sand drifts next summer; then comes another layer of branches and so on. The layers are generally exposed all the wity round, and the slopes of the hill are more or less perpendicular. These low hills are generally circular, or the larger ones are elongated in the direction of the prevailing wind; their height is $2-4$ metres. The bushes on them vary from half a metre to 2 metres high, and frequently have old and thick roots, which are exposed where the wind has destroyed the hill. On the other hand, hills of this kind may be buried in blown sand.

These Tamarisk-knolls are presumably remains of a former continuous tract of sandy soil now blown away except where the roots and shools of the Tamarisks have 
kept the sand at the old level. Mac Dougal (1908 pl. 2) gives a picture of a sand-hill formed in the same way by a species of Rhus.

All the herbaceous plants given for the shifting desert occur in the Hummock-desert, where they live under more favourable conditions, because less exposed to burial by the sand or to exposure by denudation. Amongst other herbs occurring in the Hummock-dessert the most important is Carex physodes which, though mainly a spring-plant, yet plays a considerable part throughout the summer. It is a hemicryptophyte with sympodial, horizontal rhizomes, which together with the branched roots form a network in the surface-soil (fig. 15). The growth is so dense that during spring Carex physodes forms a green-sward in places. In June the leaves have already withered, and the resting summer-buds are hidden in a tunic of dead leaf-sheaths. The plant plays a prominent part in binding the sand, but it cannot contend against a severe sand-drift. This plant and Aristida pennata do not thrive together because the latter is only luxuriant in shifting sand, Carex where it is stable.

Alhagi Camelorum is very common in many parts of the stable desert. It spreads vegetalively by aerial shoots produced from long, horizontal roots. The part above ground is annual, poorly provided with leaves, thorny and often globular. It is very hardy, and when buried it forms new aerial shoots from the leaf-axils of the old shoot, while if the sand is blown away, new aerial shoots arise from the subterranean parts. Alhagi may occur as a plant of the dunes under apparently unfavourable conditions, but it seems to depend on the ground-water not lying too deep. Like many other plants in the neighbourhood of oases, it is used for fuel.

Other plants in the Hummock-desert are: Tournefortia sibirica, similar in habit to a Lithospermum, rather strongly hairy, with white blossoms and light fruits which the wind gathers together in sheltered places; Convolvulus divaricatus is woolly-haired with small cordate leaves; Pluchea caspica and Jurinea derderioides are thin-leaved knap-weeds; Goebelia pachycarpa is one of the Papilionaceae with pinnate hairy leaves; Haplophyllum obtusifolium is a bright green glabrous 


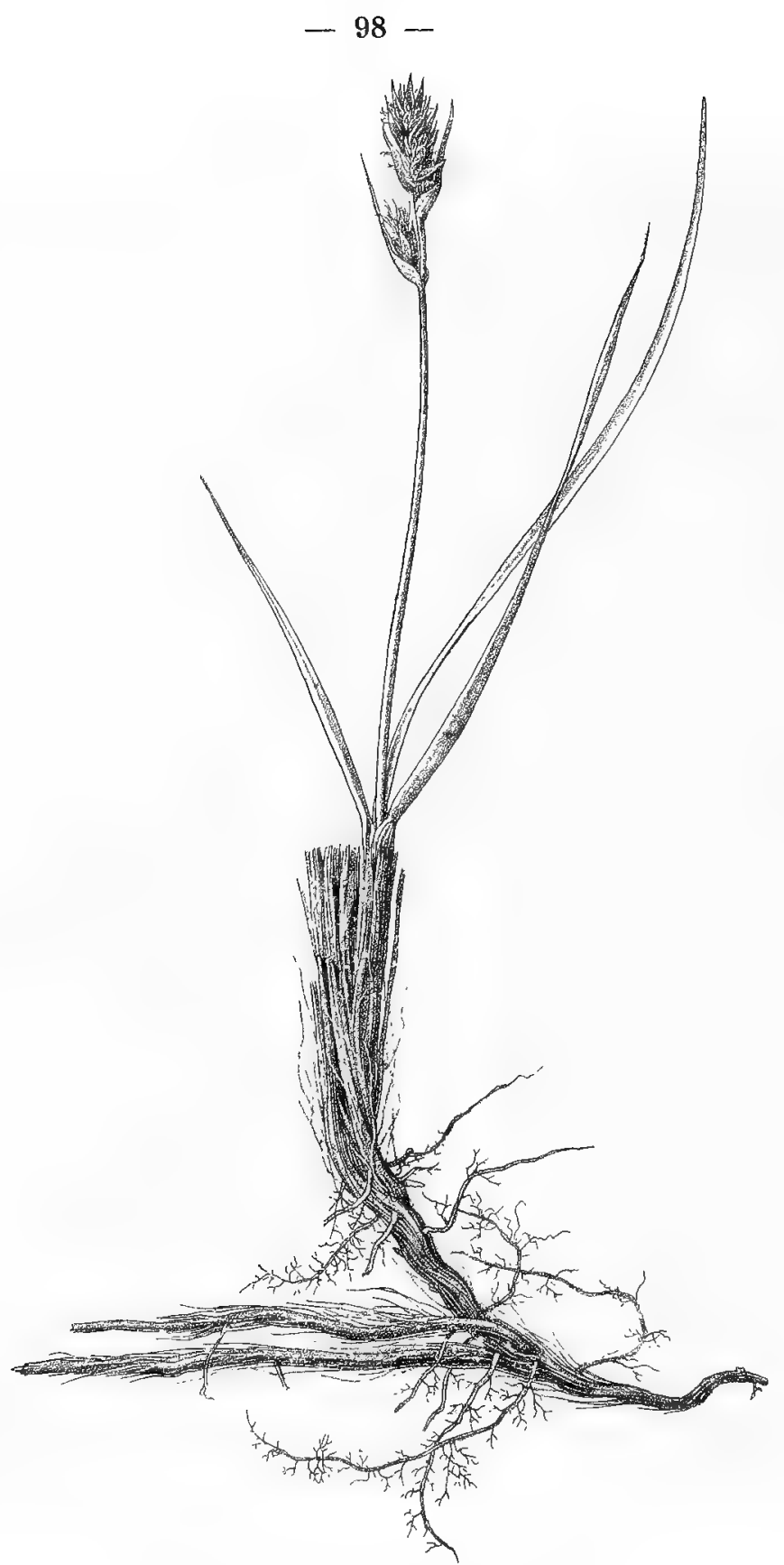

Fig. 15. Carex physodes. April (nat. size). 
undershrub with an offensive smell; Artemisia, an undershrub, and Peganum Harmala one of the Zygophyllaceae with a thick tap-root and prostrate branches. These species are all xerophytic in structure, but at the same time somewhat mesophytic since they are all comparatively leafy. The following species occurring in the lower sandy basins are halophytic in structure. Cressa cretica, a geophyte with salt-excreting leaves, Zygophyllum-species with thick leaves, Tetradiclis tenella, Halimocnemis-species, Halanthium gamocarpum and Lipskii, Salsola crassa, spissa, sclerantha, Halostachys caspica and Euphorbia Turczaninowii, the latter with thick glabrous foliage. Most of these are annuals (summer-annuals); Cressa, Zygophyllum and Halostachys are perennials. All except Cress $\alpha$ are stem-succulents, leaf-succulents or bracteole-succulents. Some are the same species met with in the claydesert, and they all belong to the same types seen there. The lower saline parts of the Hummock-desert are thus very closely related to the clay-desert, as regards their vegetation; the two are scarcely distinguishable except by the soil.

In this connection we may quote a description by RADDE (l. c. p. 154) of the sand-areas near the border of Afghanistan (July $\left.8^{\text {th }}\right)$ :

"Diese alten festen Sandberge ernähren keine Strauchart welche auf dem jüngeren zumteil noch wogenden Sande die ersten Bedingungen zum Haften desselben darbieten. Nur wo entblösster, beweglicher Sand lagert, finde ich wenige, schwächliche Exemplare von Calligonum polygonoides Pall ${ }^{1}$ ). Auf der ganzen Strecke sahen wir meistens eine Unterlage von jetzt vollständig vergilbter Poa bulbosa, welche die Pferde dennoch gerne fressen. Alhagi Camelorum, typisch und in einer niederliegenden Varietät in graugrünen Kolorit wechselt mit Peganum Harmala ab. Beide bevorzugen den mehr lockeren Sandboden, auf dem alten festen werden sie schwächer und seltener, diesen liebt Prosopis Stephaniana, weite Strecken sind von ihm bestanden, dazwischen etwas Heliotropium dasycarpum und überall gelbes Delphinium camptocarpum, welches von der Sonne

1) C. Pallasia l'Hér. O. P. 
zur Blütezeit getrocknet wurde, so dass die Blumen beim Berühren alle abbrachen und keine Samen gebildet wurden. Andere Gebiete sind mit einer lebhaft gelbgrünen, ausdauernden Artemisia (Art. campestris L.?) bestanden. Rasch durchlaufendes Feuer, welches die spärlichen Poa-Grasflächen vernichtete, beschädigte diesen Wermut mehr, als die sengenden Sonnenstrahlen, er treibt nun oben, wo das Feuer ihn verschonte. Eine hohe Composite (Cousinia Raddeana C. Wnk.) ist schon ganz abgetrocknet, sie wählt die Gehänge zum Standorte, der Wind verwehte weithin die abgebrochenen untenher weisfilzigen Blätter und Blütenstengel. In Löchern und Windstillen bilden diese sammt Alhagi grosse Haufen von totem Burian. Das duftende, wollig bedeckte Lachnophyllum gossypinum Bg. blüht noch nicht, erreichte bis 1 Fuss Höhe und brach aus dem abgesengten Boden überall aufs neue hervor. Eine hohe Malva (Alcea sulphurea Bois.) besteht in gedrängter Anordnung die östlich gekehrten Gehänge des Kuschk-Ufers, sie könnte prachtvolle Malwengarten bilden, wenn nicht auch an ihr die Sonnenstrahlen ibre vernichtende Macht geübt hätten, Blumien und Knospen sind vertrocknet. Als sechster Florentypus ist noch die stinkenden Psoralea drupacea Bg. zu erwähnen, welche namentlich in den Thalmündungen ausschliesslich bedeutende Strecken besteht."

From a botanical point of view the Hummock-desert is closely related to the Desert of the Sand-plains, the one which Radde and Semenow call Sand-steppe and which the former author compares with "an almost calm sea". The type of landscape, as expressed by the name, is flat or slightly undulating expanses of sand. In places they are interrupted by bare "Takyl"-depressions or by moving-sands. The switch-shrubs are locally the dominant vegetation as in the hummock-desert; the same species, but here of still smaller stature, seldom higher than a metre. In other places there are no shrubs, except perhaps isolated bushes of Salsola subaphylla, and the vegetation consists then mainly or exclusively of herbaceous plants interspersed with a few dwarf-bushes such as Prosopis Stephaniana and Lycium turcomanicum. Most of the herbs take part in the spring-aspect described 
later. The summer-vegetation on the whole has the same character as that of the hummock-desert, yet my impression, without having seen many localities of this kind, is that the annual Chenopodiaceae, more especially the succulent ones play here a minor part; this would be natural, since low and therefore saline, places will rarely occur in an area which is almost level.

The minor place taken by annual succulent Summer-

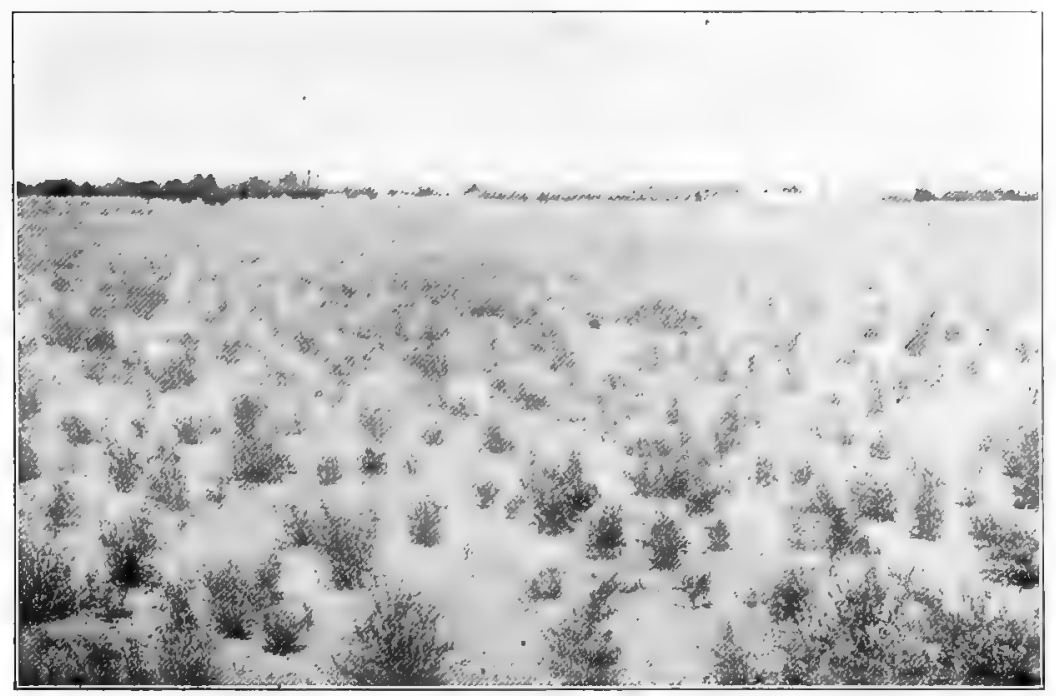

Fig. 16. A sandy and uncultivated area called "Reksar", near Buchara. Alhagi Camelorum, Zygophyllum Eichwaldii, Peganum Harmala, Goebelia alopecuroides, fewer Suaeda pterantha, Salsola sclerantha, Atriplex dimorphostegium, Ceratocarpus arenarius. May.

Chenopodiaceae in the level Sand-desert indicates some difference between this and the Clay-desert. As to growth-forms the two resemble each other, in having low shrubs, perennials, and ephemeral and other spring-plants.

The most common plants in the Sand-plain desert are Alhagi Camelorum, Goebelia alopecuroides, Zygophyllum Eichvaldii and Peganum Harmala. Fig. 16 shows a vegetation where these four species take the principal part, especially Goebelia with its multipinnate, white-haired leaves.

Other Summer-plants are Kochia prostrata and stellaris, 
Bassia sedifolia, Heliotropium Radula, Elymus sabulosus, Suceda dendroides, Salsola sclerantha and other species of Salsola, Ceratocarpus arenarius, Cressa cretica, Haplophyllum sp., Artemisia, perennial Astragalus spp., and the species of Convolvulus already mentioned. What was said about Carex physodes under hummock-desert also holds good here, namely that, although a spring-flowering plant, it plays a part during summer in binding the sand by its rhizomes and roots.

The vegetation of the desert of the sand-plains may be comparatively dense (see fig. 16), but in other places, the plants are much more scattered; the plain may indeed be so bare that one must search for the plants. In spring, however, there is always a richer vegetation.

The majority of the species are the same as in the other forms of Sand-desert (sub-formations) and so are the growthforms. In addition to small shrubs, the following types of herbs are found: thorny species (Alhagi, some species of Salsola, Ceratocarpus), hairy species (Goebelia, Kochia, Bassia, Heliotropium, Salsola sclerantha, Artemisia, Convolvalus), the succulent species are of minor importance (Suceda, Salsola). Most of the species are perennials or undershrubs; the latter include Kochia prostrata, Suceda dendroides (?), Artemisia and some species of Convolvulus. Kochia stellaris, Bassia, species of Salsola and Ceratocarpus are annual summer-plants.

If a survey is made of the distribution of the growthforms, more especially that of the annual summer-plants of the Sand-desert, it will be found that the annuals constitute the majority of the plants in the Shifting-desert, and a much smaller proportion in the Desert-plains. Of the herbaceous plant-species given above for each sub-formation, 62 per ct. in the shifting Sand-desert, 44 per ct. in the Hummock-desert and 25 per ct. in the Desert-plains are annuals. Though no very great importance can be attached to these figures owing to incompleteness of the plant-lists, yet they have a certain value because they confirm the results of direct observation. The latter has taught me, that in the shifting desert such herbaceous plants as are present are generally annuals, 
whereas on the more stabilised sands these give place to perennials and undershrubs. This is only nalural, for if the perennials have not, like Aristida, unusual powers of resisting sand-drift, they will sooner or later be smothered by a shifting barchan and very few, if any, will produce seeds during the first year; on the other hand, the annual plants with a shorter growth-period will have a greater chance of surviving and ripening seeds.

The difference in the numbers of annuals in Hummockdeserts and Desert-plains appears to be due to the annual halophytic Chenopodiaceae which occur in the depressions of the Hummock-desert, but seem to be of less importance in the Desert-plains.

Finally, attention is directed to the trees of the desert (the switch trees and shrubs) which as emphasised in the preceding pages, play the most promiment part and attain the richest development in the shifting desert, while they deteriorate where the sand is stable. Sand-drift seems to be a condition essential for vigorous growth in their case and also with Aristida pennata.

Making a mental comparison between the sub-formations of the sand-desert described, we see that they have many features in common both floral and biological, but that the differences between them are not altogether to be neglected. The most important common feature which unites them and which causes them to be regarded as sub-formations and not as formations is first the general occurrence of the deserttrees, though under a somewhat different form; secondly that the soil is sand, which is saline only in the depressions so that the true halophytes play a comparatively minor part except in these places.

The different forms of sand-desert are evidently historically related in that the one must have originated from the other. What has been the course of development? It has been already pointed out that RADDE (1899 p. 16) following Oвrutschew regards the Desert-plains" the covered Sand-steppe" as the last stage in the metamorphosis of the sand; that the sand-hills, while being covered by vegetation, are gradually being levelled down through the agency of water, wind and 
burrowing rodents. In the terms used by Cowles this metamophosis is a topographic succession, due to topographical changes of the surface. Korshinsiy regards the matter from a different point of view. His opinion $(1896 \mathrm{pp} .6,8)$ is that the "normal type" of sand-desert is the Desert-plain "level or undulating areas of sand" covered with Haloxylon, Salsola Arbuscula, Calligonum, Ephedra, Ammodendron and Eremosparton, and during spring with a number of herbaceous springplants; this desert-tree vegetation Konshinsky regards not only as the most characteristic, but also as the original type (comp. above p. 36). He is of opinion that in former times a similar vegetation covered the whole area of sand, and that man is the agent of destruction to whose devastations the naked and shifting sand-desert is due. "As soon as we get away from roads and human habitations and reach more solitary places, we always find that the sand-surface becomes more closely covered with vegetation of trees or shrubs. These trees arrest the sand, not through their sand-binding roots, but through their size which modifies the force of the wind and screens the soil from its attacks. Under their protection a richer herbaceous vegetation is also developed." This development from stable to unstable desert through the agency of man must be termed a biotic succession (Cowles). This and the topographic succession mentioned above do not exclude each other.

Even if we allow that Korshinsixy is correct, that man through felling trees for firewood and through his herds of cattle roaming about, has in many places laid bare the arrested sand and thus brought about the appearance of the naked desert, - it is still probable that the Desert-plains and the Hummock-desert have originated from the shifting-desert. In what other way could the hilly or undulating sand-desert originate? With ObRUTSCHEW and RADDE I consider it most natural to assume that the normal and natural development (the regional succession, (Cowles) not the topographic or biotic one) has taken place from Barchans to Hummock-desert and from the latter to Desert-plains. It is not correct as Konshinsky states that the stable desert is always found far from human habitations, for in such places I have seen wild sand-desert almost devoid of vegetation. 
In this connection altention is drawn to the Taklamakandesert where S. Hedrs travelled for days through a desert perfectly devoid of vegetation, and far away from any human habitations.

If it has been thus established that the development of the Sand-desert has in all probability been from Barchans to Hummock-desert and Desert-plains, that it has proceeded from the most shifting condition to the more stable, then we have at the same time traced the process of development of the vegetation. This process is expressed by the order in which the various sand-desert vegetations were described in the preceding pages, and it may be shortly summed up:

1. Aristida pennata.

2. Ammodendron, Calligonum and other desert trees. A few herbs, mostly annuals.

3. Desert-trees, smaller, but growing more closely. Several herbs, among which perennials are dominant. Annual halophytes in the valleys. (Hummock-desert).

4. Small desert-trees (or none). No halophytes (or few). (Desert of the Sand-plains).

To this process of development the definition of formation by Moss might be applied. What this author (1907 p. 12) terms a formation is:

"The series of plant associations which begins its history as an open or unstable association, and eventually becomes a closed or stable association."

Even if the Desert-plain be not closed, it is in itself stable, a terminal sub-formation, and the definition of formation given by Moss thus seems to be applicable to the Sand-desert as a whole. The definition of formation by Moss applied in this way, is employed here as a means of illustrating the unity of the sand-desert and to elucidate its metamorphosis. It must be emphasised, however, that I have grouped the different types of sandy desert in the same formation not because they constitute what might be called a historical series derived from each other in a definite sequence, 
but because at the present time they agree on general lines as regards soil and growth-forms. More thorough knowledge of the vegetation would perhaps lead one to designate the different types of sandy desert as formations, or even to create more, e. g. a special formation for the vegetation of the valleys between the sand-hills. If one followed the concepts of CRAmpton in a recent paper - published subsequent to the Danish edition of our memoir - , then the different types would be regarded as formations: the Barchan desert would be a migratory (or neogeic) formation whose substratum "owes its features to recent geological processes", whereas the Desert of the Sand Plains would be termed a stable (or palaeogeic) formation; presumably the Hummock desert would also be a stable formation.

Though brought into existence in a different way, the development of the Sand-desert is similar to that of the duneterritories of northern Europe.

The Spring-aspect of the Sand-desert I hardly know from personal observation, hence the following account is mainly based on plant-lists and descriptions borrowed from Korshinsky and RADDE (1899). The Spring-plants are mostly found in the stable sand-desert, but they may also occur in the more shifting desert, especially in depressions where the moisture is greater, the clay-content larger, and the surface therefore firmer. Wherever the seeds are carried, there they must germinate when spring comes, and even on loose sand and under unfavourable conditions the ephemeral plants may still succeed in maturing their seeds; their precocious development comes here to their aid and is indeed their only means of preservation.

On stationary sand the spring-vegetation may be comparatively rich, yet nowhere does it form a carpet.

The only species which locally attempt to form a greensward are Carex physodes and Capsella procumbens. The former has been frequently referred to already (see p. 97) as it plays a great part in binding the sand. It is already in flower in March and bears fruit in April, the fruiting ear is large and inflated so that it is easily rolled along by the wind. Cap- 
sella procumbens is a small, delicate annual plant which disappears very quickly.

The remainder of the plants of the spring-aspect in the Sand-desert can be classed, like those of the Clay-desert under the groups: Ephemerals, Hemicryptophytes and Geophytes. The following species belong to the ephemerals which are the most abundant group: Triticum squarrosum and desertorum, Danthonia Forskalei, Schismus calycinus, Bromus tectorum, Boissiera bromoides, Avena sterilis, Hordeum murinum, Papaver pavoninum, Hypecoum parviflorum, Capsella procumbens, Isatis minima and emarginata, Tetracme quadricornis and recurvata, Lachnoloma Lehmanni, Malcolmia circinnata, grandiflora and Bungei, Streptoloma desertorum, Euclidium syriacum, Octoceras Lehmannianum, Goldbachia laevigata, Chamaesphacos ilicifolium, Lallemantia Royleana, Anchusa hispida, Nonnea picta, Echinospermum semiglabrum, Plantago lachnantha, Statice spicata, Valerianella Dufresnia, V. Szovitsiana, Crucianella filifolia, Erodium bryoniaefolium, E. oxyrrhynchum, Astragalus arpilobus, Ceratocephalus falcatus, Delphinium persicum, D. camptocarpum, Matricaria lamellata, Scorzonera glabra, S. hemilasia, Senecio subdentatus, Koelpinia linearis, Lactuca undulata, Heteroderis pusilla, Heteracia Szovitsii, Cotsinia alata, tenella and minuta, Dipterocoma pusilla, Centaurea moschata, pulchella and phyllocephala, Silene nana, Psammogeton setifolium, Eremodaucus Lehmanni, Aphanopleura capillifolia, Diarthron vesiculosum, Atriplex dimorphostegium.

Many species in this list occur also amongst the ephemeral plants of the Clay-desert. Those which I have not already remarked on in the Clay-desert are of the same type: low, mesophytic or slightly xerophytic plants, sappy and without much mechanical tissue, and almost all with small leaves or leaflets which are often more or less hairy. A few have glabrous leaves (Senecio, Diarthron). Thorns are found on Cousinia alata and minuta, Centaurea phyllocephala, Centaurea Moschata; a few others have rather broad leaves. Heteroderis pusilla, Hypecoum and some Cruciferae have rosettes.

A comparison between figure 17 and figures 5 and 6 will show that the ephemerals of the Sand-desert are of the same type as those of the Clay-desert. 


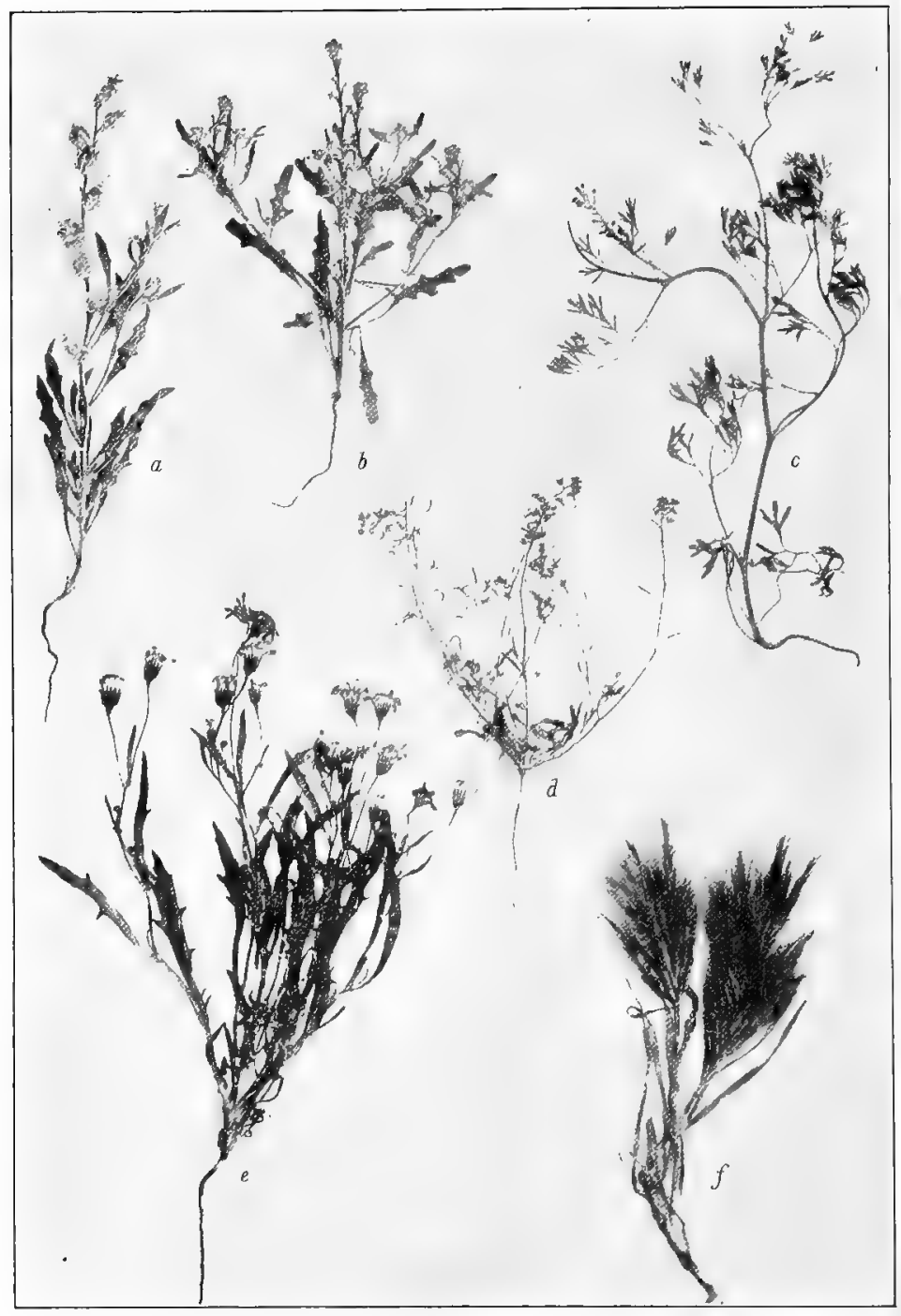

Fig. 17. Annual Spring-plants from Sand-desert: a. Lachnoloma Lehmanni. b. Tetracme recurvata. c. Fumaria Vaillantii. d. Streptoloma desertorum. e. Senecio subdentatus. f. Boissiera bromoides.

If we now consider the perennial Spring-plants, they will also be found to be the same species or species of a 
similar type as the ones of the Clay-desert. There Poa bulbosa was the most important species, and in the Sand-desert it occurs locally in great quantities on stationary soil, but Carex physodes (and C. stenophylla) are here the chief species; the horizontal rhizomes of these species are well adapted for growth on a stationary sandy soil.

Other hemicryptophytes in the Spring-aspect of the Sanddesert are Rheum tataricum (see p. 56), Eremostachys-species, Scorzonera pusilla, Astragalus ammotrophus, chiwensis, orbiculatus. The species of Astragalus have multipinnate leaves as in the Clay-desert, the leaflets are hairy and elliptical or ovate.

A number of geophytes are recorded for the Sand-desert in spring: Tulipa biflora and Androssowii, Allium caspicum and sabulosum, Rhinopetalum Karelini (all Liliaceae), Eminium Ledebouri (Araceae), Iris falcifolia, Linaria odora, and the parasites Phelipaea flava and trivalvis, the former with an inflorescence which almost attains the height of a metre ${ }^{1}$ ).

By comparing the plants mentioned, it will be seen that the spring-perennials of the Sand-desert are formed after the same type as those of the Clay-desert. It is possible that at any rate all the ephemeral species are common to both.

\section{CHAPTER 10}

\section{The Riverside Thickets (Bushland).}

My own observations on the Riverside Thickets only extend to those on the lower part of the Amu Darya, but thickets also occur along the rivers Tedshén and Murghab, etc. (ANTONOW, KORSHINSKY).

My knowledge of the Amu Darya was acquired during a boat-journey made by the expedition from Tshardshui to Chiwa and Kunja Urgentsh, a trip described by O. Olufsen in "Geografisk 'Tidsskrift" vol. 15. VI 1906.

1) Figured by O. Fedtscheniro in Bull. Jard. Bot. de St. Petersbourg 
Though the Amu Darya from Kelif to the Sea of Aral, a distance of about 1000 kilometres, has not a single affluent, it is in its lower course an imposing river. Where it is wide (3 kilometres or more) its brownish waters glide calmly along laying down banks, on which the boat is continually stranding, or removing them again. But where the river has forced its way through firmer rocks, for instance the limestones occurring in its lower course, there it becomes narrower, runs with greater speed and forms no strand.

From the river one sees the desert on both sides. Though it extends down to the river in a few places only, yet the desert gives the character to the landscape. Beyond the green fringe along the banks lie brown drifts of sand, bare slopes of loess, limestone or sandstone, or low, dry, terraced mountains on whose flat tops old ruined castles are often visible. Where the river-bed is much wider than the river, one enjoys the characteristic sight of green oases on the background of the brown desert. Thus the oasis Eldjik appears like a green plot with verdant fields, light slender poplars and dark domelike Ulmus campestris, surrounded by the naked sand. In other places thickets of shrubs, sometimes of considerable width, clothe the banks from the river to the desert; here one may see the cupola-shaped tents of the Kirghiz, and their cattle roaming about. In less fertile places one may scare the wild pheasants or see the ground torn up by the wild boar. The royal tiger is also said to visit these places occasionally.

On the eastern side of the river the desert sand in some places extends right down to the water, and the bank is then a high glissade, the lee side of an advancing barchan. (Comp. above p. 78). In such a case there is of course no vegetation on the bank.

In other places, where the river has eaten into the margin and then retreated a little, a narrow green streak will be seen mainly formed by Tamarisks, Phragmites and perhaps Erianthus Ravennae or Glycyrrhiza glabra. A firm moist soil will carry also Equisetum ramosissimum, Polygonum Bellardi, Mnlgedium tataricum, Plantago major, Aeluropus littoralis, Juncus compressus, Scirpus hamulosus -- all small, herbaceous, mesophytic or somewhat hydrophytic species. 
The larger plants given above reappear almost everywhere. In many places the thickets are formed by Tamarisks alone. Thus flat banks of clay left by the river may be covered uniformly by small plants of Tamarisks about $0,5--0,7$ metres high. These uniform thickets are partly artificial as they are cut down close to the ground every third or fourth year and taken away for firewood.

In the true thicket the Tamarisks attain a height of about 3 metres. There are two species (perhaps more, as Litwinow has in recent years described a number of species): Tamarix

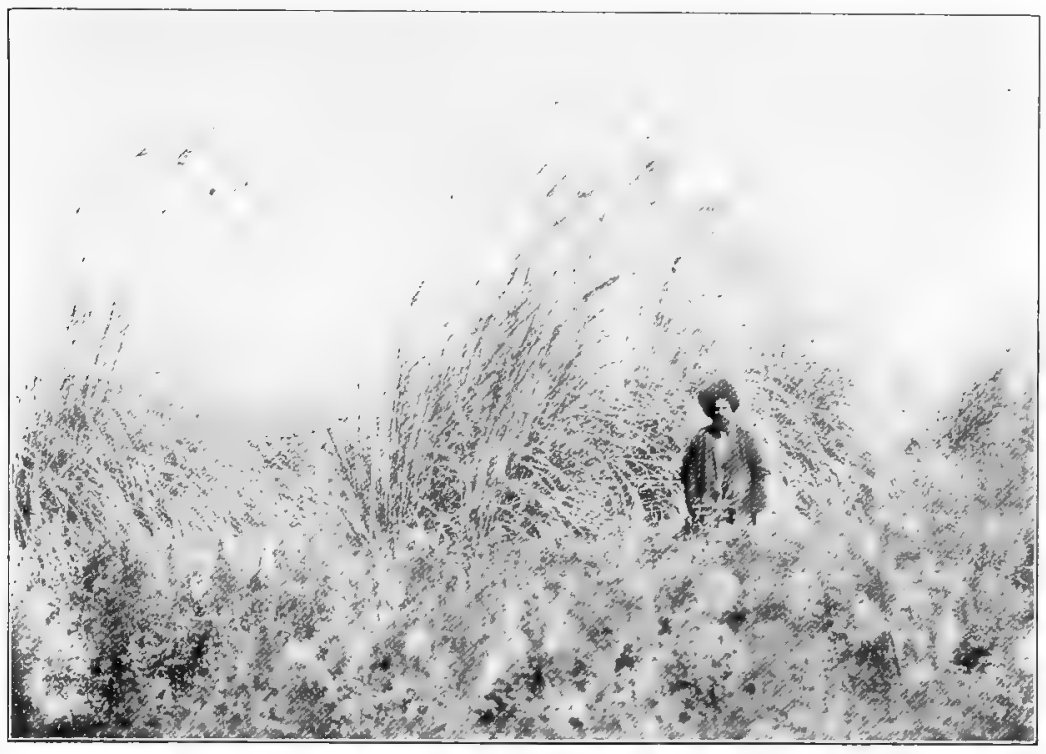

Fig. 18. Growth of Erianthus Ravennae in the river-valley of Amu Darya at Chasarasp. In the foreground, scrub of Lycium and Tamarisks. August.

hispida with its somewhat bluish green foliage and T. laxa a glabrous species. T. elongata is also met with here.

Erianthus Ravennae is a huge tussock-grass, with grey hairy tops rising $4-5$ metres above the ground, and long narrow leaves bent outwards in all directions. This plant sometimes forms pure or almost pure thickets (fig. 18), open forests of high grass-shoots, but dense enough below amongst the huge tussocks with their long leaves. On the ground 
below we have Glycyrrhiza glabra Aeluropus littoralis and (according to Litwinow) the Orchid Limodorum turkestanicum. Interspersed among the Erianthus other tall plants may be found: Phragmites, Elceagnus bushes, Calamagrostis pseudophragmites, Tamarix hispida. Erianthus more frequently, however, occurs here and there amongst other plants, the tussocks standing singly or in groups among these.

Glycyrrhiza glabra may here and there form pure or al-

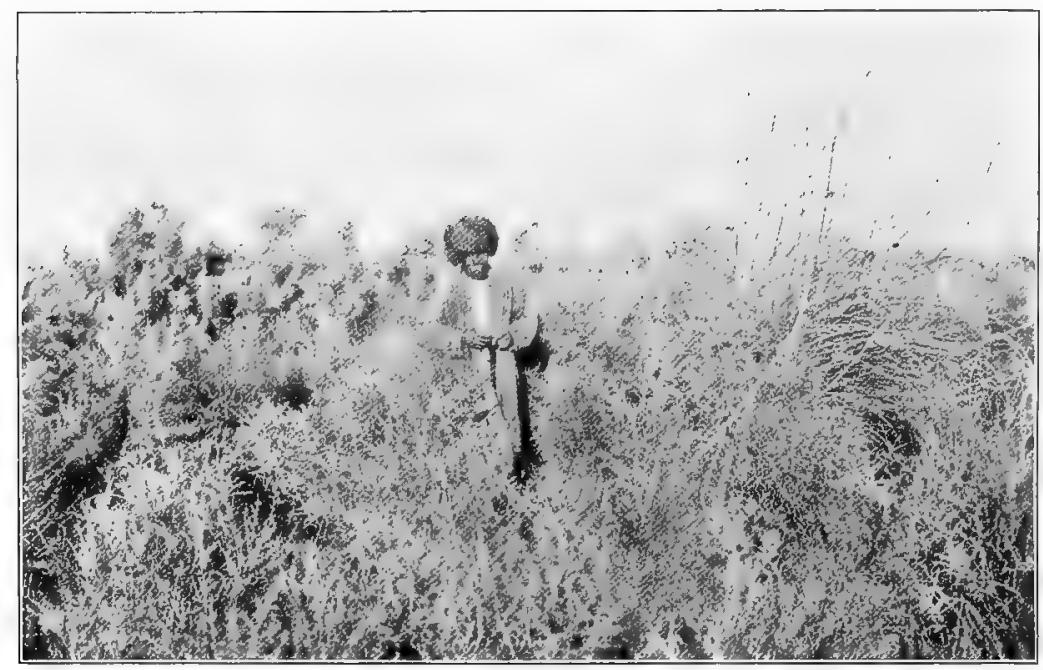

Figur 19. "Shar Togai", thicket on the left bank of the Amu Daria. In the background Tamarix and a tuft of Erianthus Ravennae, in the foreground Alhagi Camelorum, Lycium ruthenicum, Halostachys caspica.

most pure thickets. The stems attain the height of a metre (up to 1,5 metres), and stand close together borne on subterranean horizontal runners, often several together as a "radix multiceps." The species has pinnate leaves which at night assume the sleep position, all the leaflets moving vertically downwards, so that their lower surfaces touch.

Besides Tamarix, Erianthus and Glychyrrhiza, the following species occur on moist, but not wet or muddy soil: Saccharum spontaneum, very striking in appearance with its shiny, snowwhite top at a height of about 2 metres from the ground; Halimodendron argenteum, a thorny leguminous bush which 
rarely exceeds a height of $2(2,5)$ metres; Alhagi Camelorum and Lycium turcomanicum, shrubs attaining a height of up to 2 metres; Halostachys caspica a migrant from the desert, which on the river-banks is exceedingly luxuriant in growth, and amongst Tamarix bushes it may attain a height of 3 metres; also Equisetum ramosissimum, Zygophyllum Eichwaldii, and several casual visitors, e. g. Launaea nudicaulis, Mulgedium tataricum, Plantago major. Phragmites, although strictly belonging to moister places, may also be found here; so also with Calamagrostis pseudophragmites a metre-high grass with thin subterranean runners, and Typha Laxmanni.

These plants form low thickets as represented in fig. 19 . They present a particularly curly or rufled appearance, because the bushes appear devoid of leaves; nothing is seen but twigs forming a confused mass, and where (as in the picture) $\mathrm{Ly}$ cium and Alhagi are prominent the thicket is almost impenetrable on account of thorns. - The scattered Erianthus-tussocks with their orderly ranks of flowering shoots and long leaves are an agreeable relief in this otherwise confused picture.

In other places the thorny species disappear and the vegetation is formed by Tamarisks, Glycyrrhiza and grasses. Sometimes these also occur: Elaeagnus hortensis var. continentalis, bush-willows and poplars. (Salix angustifolia var carmanica, S. Wilhelmsiana, Populus pruinosa, P. euphratica).

These, especially the poplars, generally attain their full development at higher elevations. Populus pruinosa is the one I have seen most frequently but $P$. euphratica is also widespread. I saw it frequently in the country round Chiwa. Both occur either as shrubs or as trees up to a height of $6-8$ metres, and are noteworthy because of the wide variations in shape presented by their leaves as illustrated in fig. 20. The narrow leaves are mostly found on bushes which may be entirely narrow-leaved or somewhat broader leaves may occur higher up the branches. Larger trees, during the flowering period or after it, generally have broader leaves. Through a twisting of the petiole, the leaves assume a vertical edgewise position and they have a light greyish colour.

These species of poplar may occur as shrubs interspersed amongst Tamarisks, Halimodendron, Erianthus, etc., but they 
attain a greater height than the others. At higher levels where the surface is perfectly dry during summer except that it may at times be flooded by the river, but where a water-supply

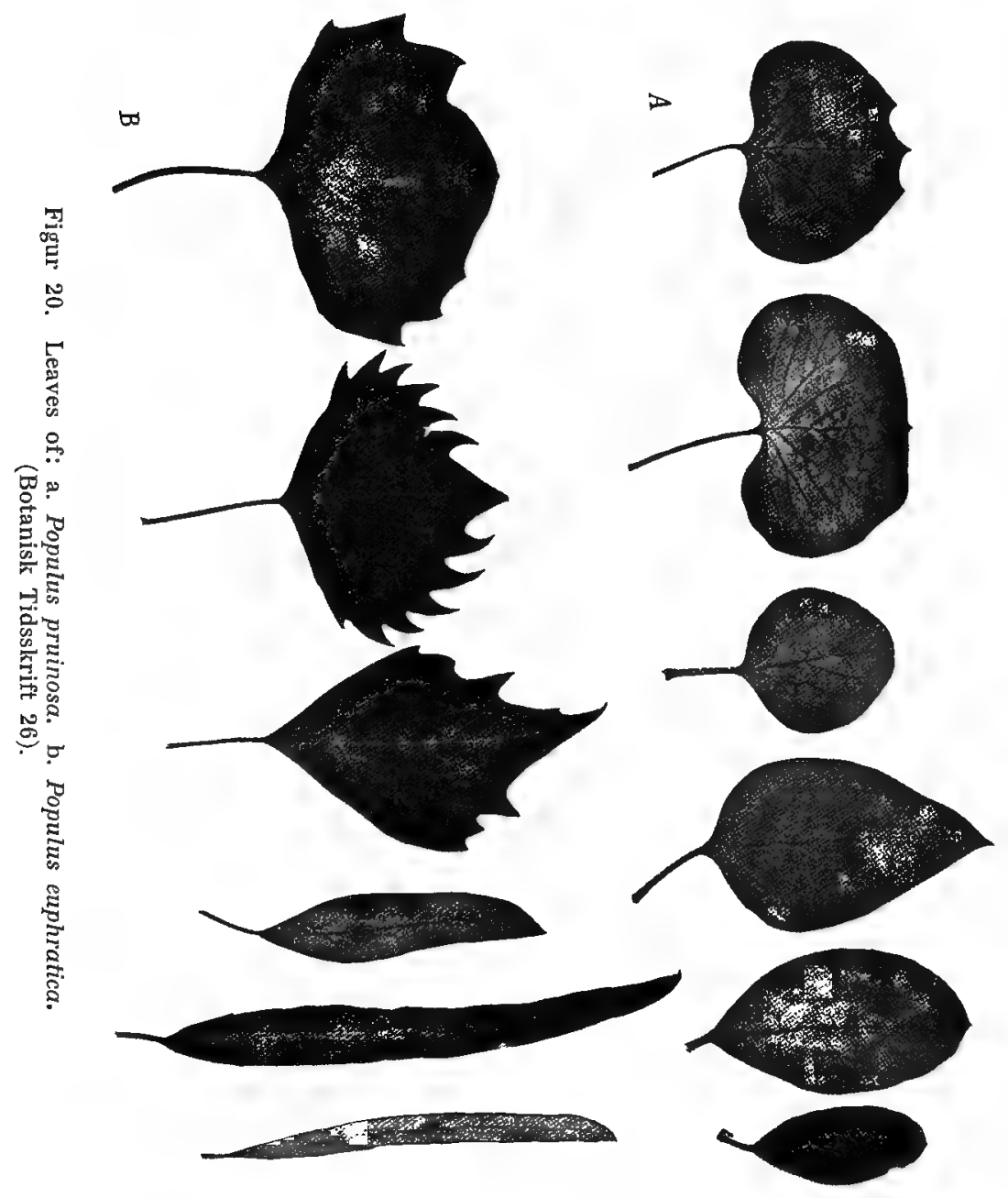

derived from the river is available at a slight depth, the poplars often become large trees sometimes interspersed in the thickets, sometimes forming forests.

Antonow describes (l. c. p. 188) how in spring when the 
rivers carry most water, the poplars ( $P$. euphratica) stand with their bases submerged, and he says that the soil round them is only dry at midsummer. I have only seen the riverside thickets from June till August, and my observations confirm that at this time of the year the poplars stand on dry land. On the area I examined the taller trees grew in more elevated localities than the low shrubs.

The poplars can attain a height of up to 10 metres. The type of vegetation they form must be characterised as forest, and AnTonow's argument against this, that they only form a

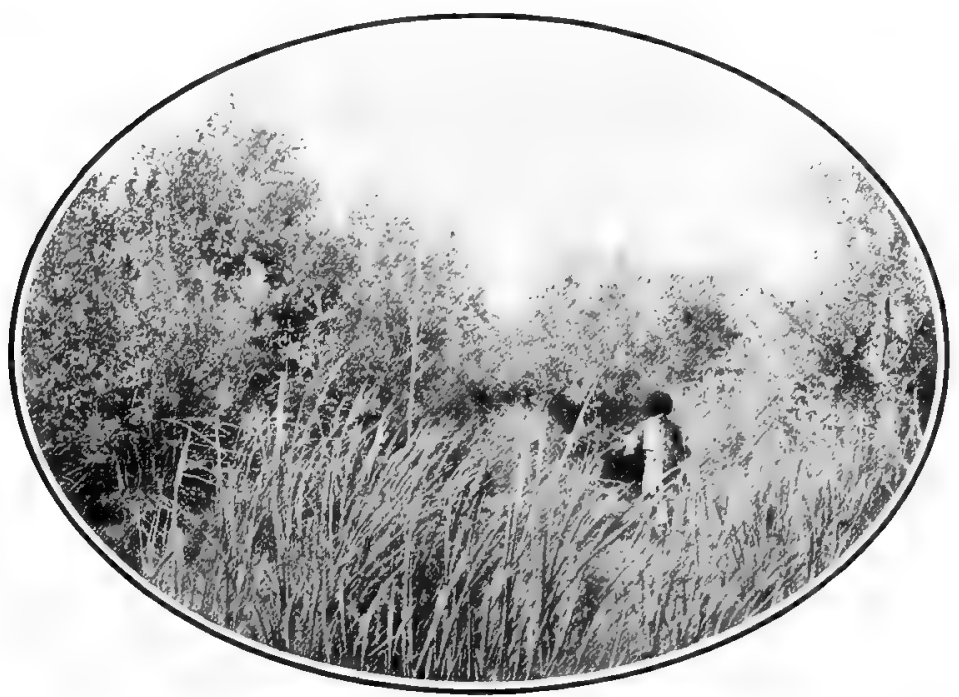

Figur 21. Forest ("Togai") at Kavaklé on the left bank of the Amu Daria. Populus pruinosa. At the left side of the man is Elaeagnus hortensis var. continentalis. In the foreground, Erianthus Ravennae. End of June.

narrow strip and "so to speak have only one dimension" does not hold good; they have a considerable width in many places, especially where the river curves and the flood-plain is much wider than the river.

From Tshardshui to Chiwa Populus pruinosa forms the forests (fig. 21) and only one other tree occurs, namely Elaeagnus hortensis var. continentalis Serw. This tree scarcely equals the poplar in height and many shrub-like specimens may be 
seen. Its foliage is still whiter than that of the poplar, so that this forest is not at all like the northern bright-green forests. The poplar forest may be quite dense, but not hard to traverse except where the undergrowth is dense, and this only occurs where light penetrates the tree-canopy. The principal species of the undergrowth are: the thorny bush Halimodendron argenteum, Erianthus Ravennae and Tamarix, these species, more especially Tamarix, cannot grow in deep shade. The other species present, Glycyrrhiza glabra, Aeluropus littoralis and Alhagi Camelorum, can endure shade, but it is very noticeable how much wider apart they stand here than in the light. When they form undergrowth they are so scattered that one may walk about without treading on them, whereas in the light they usually form a close mat. - Open glades in the forest where Halimodendron and Erianthus occur, seem in many cases to be due to human agency. Trees are cut down for building purposes and for fuel.

In the Populus pruinosa forest, lianes are represented: Cynanchum acutum, Asparagus verticillatus, Clematis orientalis (f. oblonga). These may be seen climbing high into the trees, but neither so frequent nor so luxuriant as to allow it to be said that they give the forest a special character. This may, however, be said of Cuscuta Lehmanniana, the growth of which in many parts is so luxuriant that it kills large branches and even whole trees.

Along the river-banks in the Chiwa country Populus euphratica sometimes forms forest. It has the same grey leaves as $P$. pruinosa, but their shape is still more variable (see fig. 20), the leaves of the bushes being linear while those of the trees are as broad as the broad leaves of $P$. pruinosa. P. euphratica attains about the same height as $P$. pruinosa. It may perhaps only be accidental, but where $I$ have found it as the chief species in the thicket it was more a shrub than a tree with a trunk, and it seemed to be less inclined to form a close canopy than P. pruinosa. One result of this is that the $P$. euphratica association is less forest-like and has more the character of a thicket. These thickets may be very dense, sometimes they are almost impenetrable because of the thorns of Halimodendron argenteum. In addition to this species there 
are bushes of Tamarix and Salix angustifolia with narrowleaved Populus euphratica, while masses of Glycyrrhiza glabra hide the ground. The dominant plant after the poplars is Apocynum venetum, which attains the height of $2-3$ metres and has thin stems, the growth being that of a semi-liane supporting itself on other bushes by the aid of its outspreading branches. These extend horizontally and through their own weight become pendulous, the extremities bearing inflorescences of handsome red blossoms. ${ }^{1}$ ) When Apocynam venetum grows on treeless ground, the branches lie prostrate along the surface.

Also Clematis orientalis and Cuscuta Lehmanniana I have recorded as being of frequent occurrence in thickets of the above type.

The thickets described above must be regarded as true riverside or gallery forest, an edaphic formation whose differentiation from the surrounding formations depends solely upon the presence of the river; in the first place the thickets are only found along the river, and secondly one can see that further from the river they become thinner and lower. Such is for instance the case at Kogertle on the right bank of the Amu Darya. Here the river-bed is much wider than the river and is evidently subject to periodical flooding. The plain is covered with thick luxuriant forests of poplars interspersed with Phragmiteta and glades with Erianthus and Tamarisk. Gradually as one goes farther away from the river, the forest thins out and the poplars become lower and less vigorous. The clumps of trees become separated more and more by open spaces occupied only by isolated plants of Glycyrrhiza glabra, Halimodendron argenteum, Zygophyllum Eichwaldii, Tamarix or low pioplar-bushes. The Tamarisks become more frequent until as almost pure communities they form the outposts against the brown bare hills of the desert. As will be shown later (chap. 11), the Tamarisks may even invade the desert, where by means of their very long roots they can always secure water from deeper layers.

1) A fibre obtained from Apocynum venetum is used by the natives for cordage under the name "red hemp" (Kisil Kandir). 
Another illustration may be given from Ak-jar on the left river-bank, where the thickets attain a width of about 70 metres. Nearest the river the thicket consists of Erianthus Ravennae, interspersed with Halimodendron argenteum. The latter extends farther inland than Erianthus, and towards the desert it becomes intermingled with Tamarix laxa; this plant is absent from the outer part of the thicket nearest the river but forms the whole of the inland half, growing as scattered bushes about 2 metres high and interspersed with Alhagi Camelorum. Alhagi also extends into the desert, or one might say that it passes from the desert into the thickets, for, although never seen in the most barren desert, it must be regarded as a true desert plant. This is also the case with Halostachys caspica, it may be strongly developed in the thickets, but it is especially widespread in the salt-desert (see p. 113). Zygophyllum Eichwaldii, Lycium turcomannicum and Halimodendron argenteum are occasionally desert plants confined to clay soils, but in my opinion they are more exacting in their demands and belong to more favourable habitats such as the riverside thickets.

The plants which are more definitely restricted to the river banks are: Erianthus, Saccharum, Calamagrostis, the poplars, the willows and Elaeagnus, with the addition of the marsh-plants. A few of these, however, occasionally migrate from the river-banks, thus I have seen a weakly form of Phragmites with short aerial runners, along with Calamagrostis pseudophragmites on a slightly saline plain near Chodsheli; the occurrence of Populus pruinosa in the desert is described in chapter 11.

In conclusion we give a translation of ANTONow's description of the transition from the thickets towards the deserts (l. c. p. 189):

"These thickets quickly become more stunted and poorer at each step we take from the river towards the loess-plain. Only a few Sashen ${ }^{1}$ ) from the river, the bush-forms of Chenopodiaceae put in an appearance comparatively well-

1) 1 Sachén (fathom) $=$ about 2,13 metres $=3$ Arshin. 1 Verst $=$ about 1067 metres $=500$ Sashén. 
developed because near water. Tamarix alone forms a dense fringe round the riverside thickets and stretches away from the river, far into the desert as low bushes bearing a scanty foliage. Scattered bushes may still be found 2-3 Verst ${ }^{1}$ ) from the river-bank, but what a difference between these poor stunted bushes no higher than 2 Arshin ${ }^{1}$ ) and the vigorous little trees of $2-3$ Sashén $\left.^{1}\right)$ ! The occurrence of this bush in the loess-desert (or plain) is the sign that there is probably a river in the neighbourhood, so constant are the conditions of distribution of this species."

In connection with the riverside thickets, a brief reference ought to be made to the aquatic and marsh-vegetation along the Amu Darya.

Beyond the thickets, in the water or on the very wet muddy soil, there are dense reed-swamps, up to 3 metres high, of Phragmites, (Phragmiteta) or of Typha (Typheta) including T. angustifolia, T. Laxmanni, T. stenophylla. The two last are small and narrow-leaved forms. T. Laxmanni seems to occur most frequently of the three; as already stated, it may also invade some parts of the land which is dry during summer and mingle with the plants of the thickets, but in relation to these it always plays a subordinate rôle. Calamagrostis pseudophragmites which is also a wet-soil plant with horizontal subterranean runners, prefers a somewhat drier soil than Typha, and when it occurs along with the latter it is subordinate; so also in the thickets, it is generally subordinate to the plants of the thickets. Calamagrostis however, may form a pure association on submerged soil.

In the irrigation-canals and ditches, the following plants were observed: Scirpus Tabernaemontani and S. maritimus, $Z$ anichellia pedicellata, Potamogeton perfoliatus var. Mülleri.

At Giaur Kalá, I saw a deserted branch of a river ("Stariza," see p. 33) now a lake, and in this the following plants were growing: Phragmites communis, Polygonum amphibium, Potamogeton perfoliatus and lucens.

These are the only notes taken on the aquatic and marsh regetation of the Amu Darya, but they can be supplemented

1) See note page 118 . 
by plants which I saw in the Turkestan herbarium in the Imperial Botanical Gardens at St. Petersburg; according to the labels they were all collected on the Amu Darya near Chiwa.

Najas major Roth., N. minor All., Ruppia maritima, L., Zanichellia pedicellata Fr., Butomus umbellatus L., Vallisneria spiralis L., Salvinia natans Hoffm.

The following species which 1 collected in various small Chiwensian lakes may perhaps be of interest in this connection.

In salt-lakes where Salicornia not only"fringed the border but also entered the water: Phragmites (withered), Scirpus affinis, Ruppia maritima. (Comp. above p. 55).

In fresh or slightly saline lakes, Phragmites is often dominant; the growth is here very dense and strong, and single reeds may attain a height of more than 4 metres.

In other small lakes, Typha angustifolia and T. latifolia are dominant, interspersed with Scirpus littoralis or Calamagrostis pseudophragmites, and in lakes of this kind the following submerged plants were found: Potamogeton crispus and fluitans, Myriophyllum, Ceratophyllum demersum, and Polygonum amphibium with floating leaves.

\section{CHAPTER 11}

\section{Descriptions of Vegetation from selected Localities.}

In the previous description of the various desert-formations, the distinction between them is based mainly on the soil in which the plants grow, but it has also been attempted to characterize them by means of their growth-forms. Taken as a whole it seems to be the case that a different soil produces different growth-forms. One thus refers to the switch-trees and the dry and thorny herbs of the Sand-desert, to the dwarf-bushes and halophytes of the Clay-desert, and to the richly leaved trees and lianes of the Riverside Thickets. 
But the formations pass over one to the other, and there are species common to several formations. A description of the individual formations such as has been given in the preceeding pages can therefore only present a schematic view of the vegetation. It may bring the physiognomy of the vegetation more clearly before the reader if I reproduce here a series of descriptions from selected localities in the desert of Transcaspia.

1. Sand-desert at Tasha-Kirr on the right bank of the Amu Darya. June 22 $2^{\text {nd }} 1899$ :

The Sand-desert in this place stretches right down to the river with a high glissade slope, and that this condition has probably existed for a long time may be confirmed a little farther north where there is a long high cliff of sandstone 8 to 10 metres high. This cliff consists of strata of conglomerate with much sand (the stones attain the size of a bean). Peculiar forms of erosion are shown, low columns and pillars of sandstone crowned with larger masses, probably the remains or more resistent strata which have protected the lower parts.

The brown desert behind is very rugged, dune behind dune each with crescent-shaped concavities turned towards SE. Tamarisks grow on the dunes nearest the river-valley, sometimes up to the summits, the bushes being about 2 metres high. Where the river has eroded the foot of the glissade so that the sand has fallen down, one sees the stems and long roots of the Tamarisks hanging on the slope.

Farther into the desert, the fresh green colour of the Tamarisks is lacking, but many dead remains of old stems and branches were seen, probably Tamarix. This is a sombre, naked desert formed of large, crescent-shaped dunes. The larger plants stand hundreds of metres apart. The most common is Aristida pennata. None of this plant was seen in the most exposed places, the tops of the dunes. Calligonum and Ammodendron on the contrary defy the most unfavourable conditions and thrive well. Calligonum-bushes were seen on the very tops of the downs, a height of about 2 metres, and there was also a small tree with a stem. Now and again a bush of Smirnowia turkestana was found, its large, vesicular 
fruits gone, but they were seen hanging in the grass-tussocks.

In depressions where the soil is more gravelly, flat and without loose sand, there grows a considerable abundance of Horaninowia ulicina an annual saltwort with acicular leaves, and Heliotropium (Rarlula?), together with a few Cousina annua. The pale yellow blossoms of this plant protrude from the heads which do not open but remain closed together as if to protect the gynoecia.

This desert locality has a deep sandy soil and the plants are dry sand-plants. There are no halophytes, neither annuals nor perennials. Saxaul is also absent.

2. Sand-desert outside the town of Petro-Alexandrowsk (Chiwa) Juli $1^{\text {th }} 1899$.

A dune area where Alhagi Camelorum is dominant, with a sparse admixture of Halimocnemis in the depressions and on the dunes, and Aristida pennata on the dunes only. It is noteworthy that the Alhagi association here suddenly ceases without any apparent reason, the dunes beyond are naked but otherwise quite similar to the ones covered with Alhagi. There seems to be no other reason for this, than that Alhagi in its subterranean migration aided by its horizontal roots had not yet extended its range any further. A few plants occur on the bare dunes; Aristida pennata and Calligonum; and in depressions Agriophyllum latifolium and minus, Halocnemum strobilaceum and Heliotropium $s p$.

The vegetation is thus chiefly made up of sand-plants, but a few succulent halophytes occur (Halocnemum, Halimocnemis).

3. Sand-desert south of the town of Chiwa. July $11^{\text {th }} 1899$.

Here the sand is very distinctly sorted out by the wind, the coarser sand being darker in colour than the finer. The coarser sand lies in great quantities on the crests of the wavelike drifts and on the windward side of the dunes, while the fine sand is found between the wave drifts and forms the greater part of the sliding mass on the lee side of the dunes. The smaller dunes formed in the shelter of plants or other obstacles also consist of the fine sand, and so assume a lighter colour than the surrounding surface. Over 99 per ct. 
of the fine sand has grains less than $0,5 \mathrm{~mm}$ and some of this is smaller than $0,25 \mathrm{~mm}$. The greater mass of the coarse sand is between 1 and $0,5 \mathrm{~mm}$ in diameter.

The larger dunes here are very long, but comparatively low ( 2 about to 3 metres) narrow, and crescent-shaped. Their direction is about NNE-SSW, with their lee sides towards ESE; they must consequently have been formed by winds from WNW. The soil between the dunes is sandy also, no clay is visible.

No vegetation is found as a rule on the dunes themselves. Aristida pennata is rather common, but it does not grow, or only rarely, on the most shifting, crested dunes. Alhagi Camelorum and the other herbaceous plants prefer still calmer places. Nor do the switch-shrubs occur frequently on the shifting sand; of these Eremosparton aphyllum, Ammodendron sp., Smirnowia turkestana, are found as low bushes which may attain a height of about a metre. Ammodendron is here very thorny (A. Siewersii?). The shrubs are very broad, some measuring about 1 metre in diameter. One had become treelike through the lower branches on the stem having been killed by some previous sand-drift.

The most common plant in the desert here is Convolvulus erinaceus (see p. 94), which at this season shows numerous small pink blossoms. It is plentiful everywhere except in the deeper valleys and on the tops of the dunes. Its form is a leafless, thorny ball. The roots are white and very long. The sand has been blown away from many of the plants so that they look like small trees with stems which are in reality the upper rootstocks. If still more sand is blown away, the plant falls prostrate on the ground. Thus roots over a metre long can be found lying on the surface of the sand fixed at one end only, and still having small green shoots.

Uncovered vertical stems of Alhagi are also seen, dead at the end and with new aerial shoots springing from the lower, previously buried parts; also buried specimens which have formed new aerial shoots from the axillary buds of the upper leaves.

Heliotropium Radula (?) is also common, growing in the way already described (see figs. 22, 63). There are rhizomes 


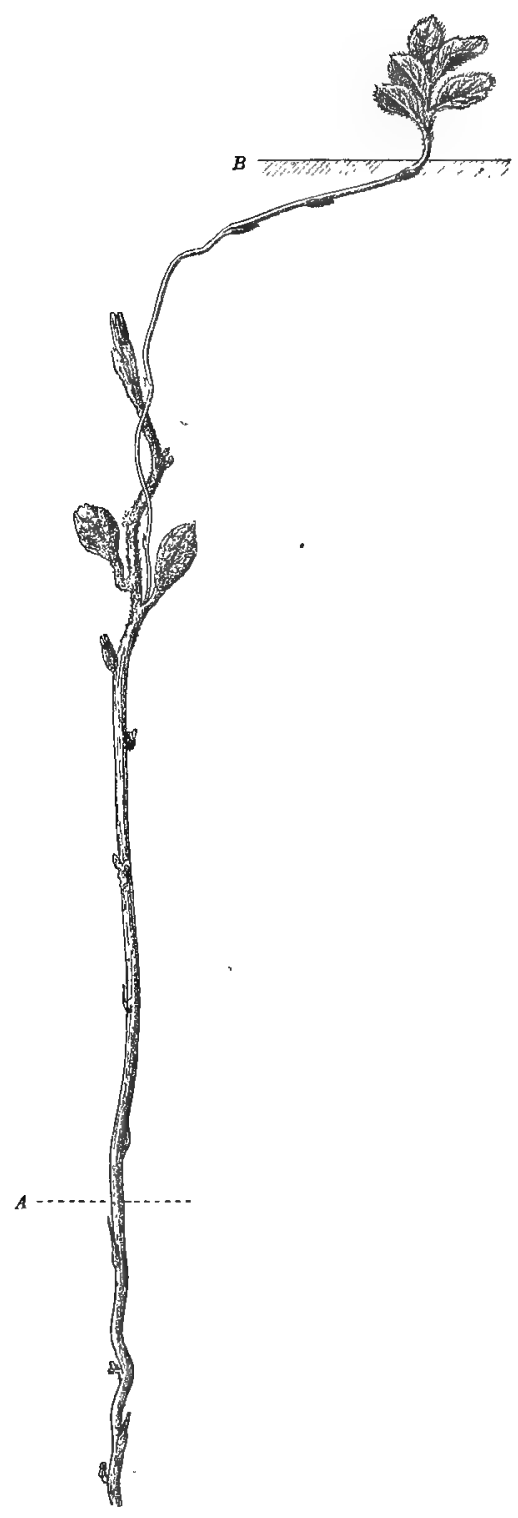

Fig. 22. A buried shoot of Heliotropium (Radula?) with a rejuvenating shoot. $A$, the former surface-level; $B$, the present surface. 
bearing dwarf-shoots others bearing long-shoots; the deeper rhizomes appear more disposed to form flowering longshoots, while those nearer the surface of the sand (warmer and drier) mostly form dwarf-shoots. Several rhizomes laid quite bare still carry living aerial shoots, both short-shoots and long-shoots. Fig. 22 shows a buried long-shoot on which one of the upper axillary buds has formed a new aerial shoot which forms a rosette on the surface of the ground.

Horaninowia ulicina and Agriophyllum minus, dry annual plants with thorn-tipped leaves, are also common. Both have been already referred to. There are also the annuals Crozophora gracilis and Euphorbia cheirolepis, one woolly-haired, the other with glossy leaves.

These plants form here an unusually rich desert-vegetation, the average distance between the plants is about one metre.

In moist depressions the vegetation is still denser, and includes Lycium ruthenicum, Halostachys caspica, Peganum Harmala, Pluchea caspica, Alhagi and especially Aeluropus repens.

This locality forms a transition stage between the shifting desert and the hummock desert. Succulent halophytes occur only in the depressions; but here also the soil is sand. On the higher sand, dry plants only are present.

4. Sand-desert north of Mailé Togai on the right bank of the Amu Daria. June 22. 1899.

The soil, formed of sand, is fairly level with low dunes. Aristida pennata grows sparsely and not luxuriantly, Carex physodes on the contrary is rather frequent; Heliotropium sp. (Radula or sogdianum), Agriophyllum latifolium and dead stems of Cistanche also present. The switch bushes grow comparatively close together but are stunted: Haloxylon, Ammodendron, Salsola Arbuscula, Calligonum Caput Medusae are metre-high bushes; some small single-stemmed trees of Ammodendron attain a height of 1-2 metres.

A dark-spotted lizard, Scaptira grammica, was captured here, also a long slender greyish-green snake, very active in its movements, and which climbed up the bushes and hid itself among the branches. 
This is a Hummock-desert. Earlier in the year there were probably numerous spring plants, but they have disappeared now.

5. At the railway-station Chodsha Dawlet between Buchara and Tshardshui. June 10. 1899.

The boundary of the oasis lies a short distance to the east of Chodsha Dawlet, but still far into the desert one sees well-preserved ruins of houses apparently not very old. The country has formerly been cultivated, but has been abandoned on account of scarcity of water; it is uncertain whether this is because the Serafshan river carries less water than formerly or whether more water is now utilised in its upper course.

The soil here at Chodsha Dawlet is loose, fine, slightly drifting sand. The ground is flat, with some knolls or level surfaces of loess the original soil; sometimes with small white patches of powdery salt. In other places there are small dunes barely a metre high. Near the railway is a small wood, no doubt planted, of Saxaul, (Haloxylon Ammodendron). Here it is a shrub rather more than 3 metres high, with several stems, the outer ones bending obliquely outwards. Round the foot of each bush there is a hillock of slightly cohesive sand which partly owes its existence to the shelter of the plant, partly perhaps to mice whose holes are not hard to find in many of the hillocks. - The average distance between the Saxaul bushes is about 3-4 metres. On the level clay-flats, the bushes do not thrive well, they are sparser and any present are half dead. On the contrary Lycium ruthenicum is quite at home here, bushes of this species attain a height of over a metre. They are even more dreary looking than the Saxaul shrubs, dry, grey and stick-like. Smirnowia turkestana occurs in a few places as low shrubs together with the thick-leaved hemicryptophyte Zygophyllum Eichwaldii. In other places I found Salsola inermis a grey herb, S. Kali and another grey annual Ghenopodiacea with fleshy, hairy leaves (Halimocnemis sp.?); also a few green Alhagi Camelorum. These were the only plants found here, and they occurred very scattered.

Walking towards the north one soon arrives at the end of the small wood. Here in the sand there were several 
Alhagi and Aristida pennala, occasionally Peganum Harmala. No others were seen, Halimocnemis (?) and Salsola inermis have totally disappeared.

The desert-lizards seen here were very amusing; three species were found at this place. The little Phrynocephalus interscapularis is brown like the sand: when resting it rolls its tail upwards like the spring of a watch and shows the underside of the tail with black and white stripes. The animal in this state soon catches the eye, but if one tries to capture it rushes off, stops suddenly, buries itself in the sand and lies as if dead. It is almost impossible to secure specimens. There is also a larger species (Phrynocephalus auritus). A third one, which I could not capture, is somewhat larger than $P$. interscapularis and has a long tail; it generally climbs the Alhagi-bushes. There are many flies and I also saw grasshoppers. Turtle-doves and Coracias and sparrows flew about the ruins.

The above-named plants soon disappear as one continues to go north, and then the naked dunes appear. They are not very high here, about 3 metres, crescent-shaped with the concavity directed almost SW. Between them the loess-soil is seen. All is bare, not a plant for long distances. In some places, however, the coarse tufts of Aristida pennata are seen. It is silent as death here, the sand on the crests of the dunes lifts slightly and looks like thin streaks of smoke. Out here there are no lizards.

If one now turns and crosses the railway walking southwards, one sees in the other direction first a more covered (planted) country and then the bare loose sand forming on the horizon immense brown dunes. The dunes of the covered belt are also in many places perfectly devoid of plants, but there are parts where Aristida pennata grows very luxuriantly forming tussocks about 1,5 metres in height and more than 0,5 metre in diameter. A few bushes of Smirnowia and Saxaul are also seen here. There are a good many depressions the soil of which is sand, they are rather well covered: flowering Alhagi Camelorum, a large-leaved form of Aeluropus repens, Pluchea caspica a metre high, small Phragmites and especially Tamarix shrubs, attaining a height of 2 metres or more. An 
advancing dune of about the same height is in process of burying some of them, the bushes impede the progress of the sand but where there is a break in the Tamarix the dune presses forward curving in a south-westerly direction.

6. Desert south of the town of Kunja Urgentsh (Chiwa) and south of a branch of the Amu Darya running towards the west. August 4. 1899.

Along the river as a green belt runs a rugged tract of sand thickly covered with Tamarisk-bushes. These are some of the Tamarix dunes already described (p. 96) which are stationary and stratified, but the bushes also grow in great numbers on the loose shifting sand. Interspersed among the Tamarisks are thousands of Alhagi Camelorum often extending right up to the top of the dunes; on lower places Pluchea caspica, Lycium ruthenicum and Phragmites communis. The boundary between this green band and the desert is sharply defined. The latter is a naked plain with loess as a soil; it is stable and flat and bordered in the far distance by the green trees and fields of an oasis. In some places, however, the soil is torn up, possibly through wind-erosion, and here the loess shows a well-known characteristic in that it forms perpendicular shelves, the largest a couple of metres high.

To the west lie some large and almost naked sand-dunes which show by their shape that north-easterly winds prevail; here and there smaller dunes appear on the loess-plain, and in their neighbourhood the clay-soil is covered by a level layer of sand.

Isolated tufts of Aristida pennata grow on the larger dunes. In a sandy valley between two dunes one notices even from a distance fresh green patches which are groups of large, vigorous Alhagi. The glissade of the most easterly dune has commenced to pour its masses of sand over them, and some show now only the outmost shoot-apices projecting above the sand, their days being numbered. On the other side of the dune, Alhagi suffers in the opposite way, for here the sand is blown away from it and strong vigorous bushes of aerial shoots are overthrown and lie on the sand, anchored by stems metres in length. Previously while these were covered by soil, they were vertical. One could see that they 
had been laid bare quite recently and that there had not yet been time to form new aerial shoots from their lower parts.

Yet another plant-species is seen on the larger dunes, some bushes of Populus euphratica, attaining the height of a man. This plant is a migrant from the river valley. Only a little group occurs at a single place where sheltered by one of the larger dunes.

The deepest valleys among the dunes extend down to the loess-soil which is here perfectly naked. If any vegetation previously existed, it has been smothered by the sand which has only recently been blown off such valleys.

Seen from the tops of the dunes, the loess-plain is not green, but is closely studded with green patches. On account of the neighbourhood of the river it is unusually thickly covered with vegetation. The following plants occur: low shrubs of Salsola subaphylla and S. Arbuscula, Alhagi and three annual species Ceratocarpus arenarius (thorny), Halanthium Lipskii and Salsola sogdiana (leaf-succulents).

Places where there is sand are distinctly richer in vegetation than the parts with pure clay. The first reason for this it that where the vegetation is more plentiful, the sand drifting along the plain becomes fixed. Thus hillocks of sand are drifted together here and there under the Salsola bushes, and the occurrence of e. g. Heliotropium is conditional on the presence of sand.

Another and doubtless a more important reason is that the sandy soil affords more favourable conditions for vegetation than the clay-soil. Some species are only found on these sandy soils, the most important being Tamarix which grows both on stationary stratified dunes and on loose sand. There is a tendency for the sand in dunes of this kind to form incrustations on the surface. Calligonum $s p$. (not frequent) and Heliotropium Radula are also present.

Some of the species of the loess-plain are more frequent in occurrence and more strongly developed on sandy soil than on clay. With Alhagi this is mainly manifested by its bushes on the pure loess soil occurring as a rule singly, while on the sandy soil many were grouped together. This is doubtless due to the fact that the long horizontal roots 
which produce aerial shoots penetrate the sand easily, but the clay only with difficulty. Salsola Arbuscula was also more vigorous, its branches and leaves being less stiff when it grew amongst the dunes.

7. Desert at Kis Kalá on the right bank of the Amu Darya. June 23. 1899. This locality has previously been referred to (p. 75).

Kis Kalá is one of the many ruined castles along the Amu Darya; it stands on the summit of a table-topped mountain. (The rock, a kind of limestone, cannot unfortunately be determined, as the sample I collected has disappeared). Round the mountain itself lie great accumulations of detached gravel and stones. The soil of the desert is partly sand forming small dunes, partly gravel with coarse sand and many stones. Of these two soils the sand carries the richer growth, and low shrubs of the following species occur: Haloxylon Ammodendron (thick-stemmed 1-2 metres high) Salsola Arbuscula, Calligonum sp., Ephedra alata, Ammodendron sp. and Reaumuria oxiana (very scattered), Tamarix hispida, stunted specimens of Salsola subaphylla. Near the river, and only there, Lycium ruthenicnm is abundant and aids in the formation of dunes 1-2 metres high. Along with it are other plants restricted to the river-banks such as Phragmites communis and Erianthus Ravennae. On the loosest sand in the desert Aristida pennata grows, but only a few occur and these are small and poorly developed; the sand-drift in this locality is very slight and the soil is not loose enough for it. Alhagi Camelorum, on the contrary, is found in great numbers, besides withered stems of Phelipaea. The following species were also collected: Agriophyllum latifolium, Heliotropium sogdianum, Salsola sogdiana and aperta, dry or thorny plants, true sand-desert plants; in addition we found Euphorbia Turczaninowii, Halimocnemis macranthera and villosa, Aeluropus littoralis. These last species are characteristic for this locality as they are halophytic in type; the three first named are succulent-leaved plants, the species of Halimocnemis being very grey on account of their hairs, the grass Aeluropus is a characteristic plant of the saltdesert (p. 52). These plants indicate that the soil is shallow and the ground-water not deep, and with this is correlated 
the smallness of the bushes and the poor development of Aristida. The occurence of an Allium $s p$. (with ripe fruits) is likewise indicative of such a soil.

In a depression with the soil hard and crackling with salt and the subsoil moist, we have a Salt-desert flora consisting of Halocnemum strobilaceum and Aeluropus littoralis, here the ground-water is still nearer the surface. The stony soil is more sterile than either the sand or the salt; the plant characteristic for this soil is Reaumuria fruticosa, a shrub half a metre high, with thick stiff branches densely clothed with very small thick leaves crusted with grains of salt. A few Tamarix hispida and Salsola Arbuscula occur here as stunted bushes with wide bare spaces between them. On loose stones I gathered the following lichens: Sarcogyne perileuca Wain., Placodium Paulsenii Wain., Acarospora interrupta (Ehbg.).

8. Desert at Kara Aigir on the left bank of the Amu Darya. June 26. 1899.

The desert, which lies beyond the riverside thickets of Tamarisks and Phragmites, is limited towards the thicket by a low round hill. The soil is firm, consisting of a kind of loess, but slightly pervious under the surface. The desert is undulating, the soil always the same, but as one proceeds away from the river it becomes more and more covered by gravel or sand. It is noteworthy that this desert poor in sand lies to the west of the Amu Darya: the prevailing northerly and northeasterly winds drift the sand into the river which carries it along towards the north. This is why the western bank is regularly poorer in sand than the eastern one.

On the clay-soil there is scattered vegetation of stumpy, shrubby plants about $\mathbf{1 - 3}$ metres apart on the average. Salsola rigida occurs most frequently as a small bush about 30 centimetres high, densely coated with hairs and dry like a stick. The leaves are cylindrical with central waterstoring tissue. Other shrubs present include Lycium ruthenicum and Calligonum sp. about a foot high.

The sand occurs in patches which are really low dunes, lowest near the river and becoming higher away from it. The layer of sand very seldom attains the thickness of 1 
metre. This sand is more closely covered with vegetation than the clay, and two species are specially characteristic: Carex physodes (the aerial parts withered, but fresh buds present far down in the dense mat of old sheaths) and Artemisia herba alba (a form of A. maritima s. lat.); the Carex is restricted to the sand-patches, the Artemisia occurs now and then on the bare clay. The following species likewise follow the sand: Haloxylon Ammodendron, small shrubs about 0,5-1 metre high, Salsola sogdiana, Halimocnemis villosa, Halanthium gamocarpum, Cousinia dichotoma. Halimocnemis and Halanthium are grey annual Chenopodiaceae (leaf-succulents) never found on deep dry sand; they are typical clay-plants, and along with the other plants mentioned, they occur here chiefly on the sand because it only formed a thin layer and thus created more favourable conditions by protecting the firm subsoil from desiccation (see above p. 80).

There is a relation between the presence of the sand in this place and Carex physodes. It is very improbable that this sedge could originally have grown on the clay-surface and thus have caused the sand to become fixed. I never found it on clay, nor has any one else so far as I know, and it would not be in accordance with its mode of growth. The sand must have been present first, perhaps retained by stems of clay-plants, and then Carex physodes appeared its vesicular spathes are easily transported - the stability of the sand being assured by its presence. More extensive investigations may perhaps decide this question, but my observations in this locality were very limited.

9. Desert at Dana Shér Kalá ("the castle of the wideawake tiger") on the left bank of the Amu Darya. June 27. 1899. This locality (see also p. 76) lies west of the river, like Kara Aigir (No. 8) and the locality described next (No. $10)$, so that there is very little sand. The desert is a stony, gravelly plain (coarse sand and small stones) with an exceedingly poor vegetation. The only species is Salsola rigida as small scattered shrubs with little heaps of sand round the base - a sign of sand-drift, but the sand does not remain lying. In one small valley, sand had accumulated and the 
vegetation was richer: Salsola Arbuscula, Calligonum sp., Artemisia, Saxaul, Salsola sclerantha.

10. Desert at Ak Jar and northwards, on the left bank of the Amu Darya. June 28. 1898.

An undulating plain of argillaceous slate and loess covered with a layer of sand or gravel. The slate appears on the surface here and there, forming small knolls. There is a slight sand-drift and small hillocks of sand lie round the base of the shrubs. The vegetation in places is uncommonly rich, the distance between the shrubs being on an average about 2 metres. The most common plants are: Salsola rigida and Arbuscula (the clay-form, in flower) and Reaumuria oxiana. This plant is more conspicuous than the others because its foliage is darker and not so grey; it has fruits and flower-buds, but no flowers open $(2 \mathrm{p} . \mathrm{m}$.). Lycium ruthenicum rarely occurs (any specimens seen are over a metre high), Saxaul is more frequent but thrives badly here rarely attaining a height of 0,5 metre, many specimens are quite red or reddish. The herbaceous plants are Salsola sclerantha, Lepidium obtusum, and in other places: Halimocnemis villosa and Suceda sp. The latter sometimes scrambles over Lycium and other shrubs somewhat like a liane; it may attain a height of half a metre.

The depressions are small "Takyr" (p. 55), the lightcoloured soil is stiff, regularly cracked by desiccation and often lacks vegetation. In some places, however, Halimocnemis villosa occurred abundantly; in one depression Halocnemum strobilaceum grew luxuriantly, I measured a circular tuft 140 centimetres in diameter.

A similar gravel-plain at Pitnjak, not far from Ak Jar, was sparsely covered with Peganum Harmala, Convolvulus eremophilus and Anabasis salsa. No switch-bushes were found here.

11. A low mountain north of the fortress Ustyk (Buchara) on the right bank of the Amu Darya. June 19. 1899. The mountain is terraced with low crags about $1-4$ metres high. It consists of a soft stratified sandstone with diverging layers mostly red in colour. Behind it stretches the bare sand-desert. On the mountain the soil mainly con- 
metre. This sand is more closely covered with vegetation than the clay, and two species are specially characteristic: Carex physodes (the aerial parts withered, but fresh buds present far down in the dense mat of old sheaths) and Artemisia herba alba (a form of A. maritima s. lat.); the Carex is restricted to the sand-patches, the Artemisia occurs now and then on the bare clay. The following species likewise follow the sand: Haloxylon Ammodendron, small shrubs about 0,5-1 metre high, Salsola sogdiana, Halimocnemis villosa, Halanthium gamocarpum, Cousinia dichotoma. Halimocnemis and Halanthium are grey annual Chenopodiaceae (leaf-succulents) never found on deep dry sand; they are typical clay-plants, and along with the other plants mentioned, they occur here chiefly on the sand because it only formed a thin layer and thus created more favourable conditions by protecting the firm subsoil from desiccation (see above p. 80).

There is a relation between the presence of the sand in this place and Carex physodes. It is very improbable that this sedge could originally have grown on the clay-surface and thus have caused the sand to become fixed. I never found it on clay, nor has any one else so far as I know, and it would not be in accordance with its mode of growth. The sand must have been present first, perhaps retained by stems of clay-plants, and then Carex physodes appeared its vesicular spathes are easily transported - the stability of the sand being assured by its presence. More extensive investigations may perhaps decide this question, but my observations in this locality were very limited.

9. Desert at Dana Shér Kalá ("the castle of the wideawake tiger") on the left bank of the Amu Darya. June 27. 1899. This locality (see also p. 76) lies west of the river, like Kara Aigir (No. 8) and the locality described next (No. 10), so that there is very little sand. The desert is a stony, gravelly plain (coarse sand and small stones) with an exceedingly poor vegetation. The only species is Salsola rigida as small scattered shrubs with little heaps of sand round the base - a sign of sand-drift, but the sand does not remain lying. In one small valley, sand had accumulated and the 
vegetation was richer: Salsola Arbuscula, Calligonum sp., Artemisia, Saxaul, Salsola sclerantha.

10. Desert at Ak Jar and northwards, on the left bank of the Amu Darya. June 28. 1898.

An undulating plain of argillaceous slate and loess covered with a layer of sand or gravel. The slate appears on the surface here and there, forming small knolls. There is a slight sand-drift and small hillocks of sand lie round the base of the shrubs. The vegetation in places is uncommonly rich, the distance between the shrubs being on an average about 2 metres. The most common plants are: Salsola rigida and Arbuscula (the clay-form, in flower) and Reaumuria oxiana. This plant is more conspicuous than the others because its foliage is darker and not so grey; it has fruits and flower-buds, but no flowers open (2 p. m.). Lycium ruthenicum rarely occurs (any specimens seen are over a metre high), Saxaul is more frequent but thrives badly here rarely attaining a height of 0,5 metre, many specimens are quite red or reddish. The herbaceous plants are Salsola sclerantha, Lepidium obtusum, and in other places: Halimocnemis villos $\alpha$ and Suceda sp. The latter sometimes scrambles over Lycium and other shrubs somewhat like a liane; it may attain a height of half a metre.

The depressions are small "Takyr" (p. 55), the lightcoloured soil is stiff, regularly cracked by desiccation and often lacks vegetation. In some places, however, Halimocnemis villosa occurred abundantly; in one depression Halocnemum strobilaceum grew luxuriantly, I measured a circular tuft 140 centimetres in diameter.

A similar gravel-plain at Pitnjak, not far from Ak Jar, was sparsely covered with Peganum Harmala, Convolvulus eremophilus and Anabasis salsa. No switch-bushes were found here.

11. A low mountain north of the fortress Ustyk (Buchara) on the right bank of the Amu Darya. June 19. 1899. The mountain is terraced with low crags about $1-4$ metres high. It consists of a soft stratified sandstone with diverging layers mostly red in colour. Behind it stretches the bare sand-desert. On the mountain the soil mainly con- 
thickets along the river-banks. This list must be regarded as an experiment. It is based on all the sources of information which have been available to me. The most important of these are: Bunge's Reliquiae Lehmannianae, Madame Fedtschenko's and Boris Fedtschenko's various works, Lipsry's systematic memoirs in Acta Horti Petropolitani, Litwinow's descriptions some in the schedules to Herbarium florae Rossicae, others in "Travaux de la Musée de l'Académie", and finally it is based on my own collections.

Two great difficulties had to be contended with in composing the list. First the records of occurrence in the various memoirs are not always sufficiently exact to allow of an accurate determination as to whether the plant in question occurs on the territory dealt with in this work, or north of our selected boundary, or on the mountains to the east or south of it; secondly it is difficult to determine the limits of any particular species in a flora which is still insufficiently investigated. I have therefore adopted a somewhat broad outlook as regards this question and have therefore excluded several "minor species" described in recent years by WINKLER, Lirwinow and others. The synonymy also presents difficulties which, however, I hope have been surmounted in most cases.

I am fully aware that the list as such has many deficiencies, but hope that it may serve the purpose for which it has been prepared, namely to give fairly accurate information about the growth-forms of the desert.

As regards the growth-forms I have chosen the system proposed by RAUNKIER, partly because, in spite of its onesidedness, it emphasises one of the most important features of plant-life, also because it is easier to handle than other classifications of growth-forms, and finally because by using RAUnKier's system it is possible to express statistical data which may be compared with corresponding data for other regions.

The biological types (growth-forms) of Raunkier (see Raunkiær 1904,1905, 1907) are arranged according to the way in which plants live through unfavourable seasons, and special emphasis is laid on the degree and kind of protection 
afforded to the dormant shoot-apices. In countries where the conditions are always favourable the Fanerophytes are dominant, their dormant buds being attached to branches which project freely into the air. The group thus includes shrubs and trees. Raunkier subdivides them into four groups according to size. Only the two lower of these groups are represented in the Transcaspian desert namely Microfanerophytes (2-8 metres) and Nanofanerophytes (less than 2 metres) whereas Mega- and Mesofanerophytes are absent. In the second column of our list Fanerophytes are denoted by $F$.

The next group is the Chamaephytes. The dormant buds of this group are found on the surface of the ground or just over it. In the former case they are plants with above-ground creeping and persistent shoots; in the latter case they are cushion-plants or undershrubs, the latter being conspicuous by their stunted stature and by the distal or apical parts of the year-shoots dying away during the unfavourable season. Chamaephytes are denoted by $\mathrm{Ch}$.

Then follow the Hemicryptophytes, with their dormant buds situated in the uppermost soil just in the surface, while the aerial shoots are not perennial. In the list they are denoted by $\mathrm{H}$.

The Cryptophytes form the fourth group, characterised by the dormant buds being subterranean or subaquatic. They include aquatic and marsh-plants denoted by $\mathrm{H} \mathrm{H}$ and Geophytes denoted in the list by $\mathrm{G}$.

The Therophytes or plants of the favourable season are the best protected, as they live through the unfavourable season as seeds, they are thus annual plants and are denoted in the list by $\mathrm{Th}$.

An attempt has been made to allocate each species in the list to the growth-form to which it belongs. This has been no easy task because of incomplete knowledge of many species, especially as descriptions and herbarium specimens are very often unsatisfactory in this respect. It is therefore probable that some mistakes have been made. Some will no doubt neutralize others, but later on it will be shown that the results arrived at by enumeration agree fairly well with statistics from other areas with similar conditions of 
life, which seems to justify the assumption that the errors of my list are excusable.

The third column of the list contains figures which denote the months in which the species in question blossoms, 3 stands for March, 4 for April, 5 for May etc.

The last column contains information as to the distribution of the species outwith the Transcaspian plain; with this, however, is here included the Balkash basin (see p. 4) while Fergana is excluded. $H$ means High-Asia, that is the mountainous parts towards the East from Hindokush and Pamir to Dsungaria and farther East. $R$ means Russia, including the Kirghiz-steppe and Siberia, and $\mathrm{V}$ means Western Asia (Asia Minor Persia etc.) and the countries of the Mediterranean. E means endemic.

The asterisks have the following signification: $V *$ means that the species is distributed towards the South to Syria and Palestine (PosT), $R^{*}$ that the species is distributed towards the North as far as Yekaterinoslaw (BÉkÉToFf), $\mathrm{H}^{*}$ that the species occurs in Pamir (O. Fedtschenko).

The distribution of the species will be further referred to in Section 4 .

$\begin{array}{cccc}\text { Growth- } & \text { Flowering- } & \text { Distri- } \\ \text { form } & \text { month } & \text { bution }\end{array}$

\section{Alismaceae.}

Butomus umbellatus L. .

HH

$H^{\star} \mathbf{V}^{\star}$

\section{Amaryllidaceae.}

Ixilirion Pallasii F. \& $\mathbf{M}$.

G 4-5 HRV

Apocynaceae.

Apocynum venetum $\mathrm{L}$.

H?

7

HRV $^{\star}$

Araceae.

Eminium Ledebouri Scott

G

$3-4$

E

Asclepiadaceae.

Cynanchum acutum L.

H

$5-6$

$\mathrm{HR}^{*} \mathrm{~V}^{*}$

Berberidaceae.

Leontice Ewersmanni Bge . .

G 3 V

- incerta Pall

G

$3-4$

$\mathrm{H}$

Borraginaceae. 


\begin{tabular}{|c|c|c|c|c|c|}
\hline Name & & & $\begin{array}{l}\text { Growth- } \\
\text { form }\end{array}$ & $\begin{array}{l}\text { Flowering- } \\
\text { month }\end{array}$ & $\begin{array}{l}\text { Distri- } \\
\text { bution }\end{array}$ \\
\hline Arnebia decumbens (Vent.) Gürke & 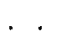 & . & Th & 5 & HRV \\
\hline - orientalis (Pall.) Lipsky . & . & & Th & $4-5$ & $V^{*}$ \\
\hline Asperugo procumbens L. . . &. & . & . Th & $4-5$ & $\mathrm{HR}^{\star} \mathrm{V}^{\prime}$ \\
\hline Echium italicum L. & . . & . & $\left.\mathrm{H}^{1}\right)$ & 9 & $\mathrm{~V}^{*}$ \\
\hline Heliotropium acutiflorum Kar. Kir. & & . . & Th & 7 & $\mathrm{HV}$ \\
\hline chorassanicum Bge. . & & . . & G & 5 & $\mathrm{~V}$ \\
\hline dasycarpum Ldb. & . & . . & $\mathrm{Ch}$ & $6-7$ & $\mathrm{HV}$ \\
\hline Eichwaldi Steud. & . . & . . & Th & $6 ?$ & HRV \\
\hline europaeum L. & & & Th & 6 & $\mathrm{R}^{\star} \mathrm{V}^{\star}$ \\
\hline lasiocarpum F.\& M. & 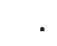 & . & Th & $7-8$ & V \\
\hline micranthum (Pall.) $\mathrm{Bg}$ & & . . & Tlı & $6-7$ & $\mathrm{R}$ \\
\hline Radula F. \& M. . & . & . & $\mathbf{G}$ & $5-6$ & $\mathbf{H}$ \\
\hline sogdianum Bge & & . & G & 5 & $\mathbf{E}$ \\
\hline transoxanum Bge. & . . & . & $\mathrm{Ch}$ & $6-7$ & $V$ \\
\hline Lappula barbata (M. B.) Gürke & & & Th & $4-5$ & $\mathrm{H}^{\star} \mathrm{R}^{\star} \mathrm{V}^{\star}$ \\
\hline - divaricata (Bge.) Gürke & . & & $\mathrm{H}$ & 4 & $\mathrm{E}$ \\
\hline - echinophora (Pall.) Kze. & & & Th & 4 & HRV \\
\hline - laevigata (Kar. Kir.) Gürke & & & Th & 4 & $\mathrm{HR}$ \\
\hline macrantha (Ldb.) Gürke & & & Th & 5 & HR \\
\hline polymorpha (Lipsky) & & . & Th & 4 & $\mathrm{HV}$ \\
\hline semiglabra (Ldb.) Gürke. & & & Th & 5 & HR \\
\hline spinocarpos (Forsk.) Asch. & . . & . & Th & 4 & $V^{*}$ \\
\hline Lindelofia anchusoides (Lindl.) Lehr & m. . & . . & $\mathbf{H}$ & 8 & HV \\
\hline Lithospermum tenuiflorum $\mathrm{L}$. & 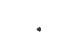 & . & Th & $4-5$ & $\mathrm{~V}^{*}$ \\
\hline Myosotis refracta Bois. . & & . & Th & 4 & $\mathrm{~V}^{\star}$ \\
\hline Nonnea picta F.\& M. & . . & . & Th & $4-5$ & HRV \\
\hline Onosma setosum Ldb. & . & & $\mathrm{H}$ & 5 & RV \\
\hline - $\quad$ stamineum Ldb. & . & . & $\mathrm{H}$ & 4 & $\mathbf{R}$ \\
\hline Paracaryum micranthum Bois & & & Th & 4 & $V^{\star}$ \\
\hline Rindera cyclodonta Bge. & & . & $\mathrm{H}$ & 4 & $\mathbf{H}$ \\
\hline - tetraspis (Pall.) & & & $\mathrm{H}$ & $4 ?$ & $\mathrm{HR}^{*}$ \\
\hline Rochelia cardiosepala Bge & . & & $\mathrm{H}$ & 4 & $\mathbf{H}$ \\
\hline leiocarpa Ldb. & . & & Th & 4 & $\mathbf{H}$ \\
\hline macrocalyx Bge. . & . & . & Th & 4 & $\mathrm{~V}$ \\
\hline - retorta (Pall.) Rchb. & . & . & Th & 4 & $\mathbf{H}$ \\
\hline Solenanthus Kuschakewiczi Lipsky & . . & & $\mathrm{H}$ ? & 4 & $\mathrm{H}$ \\
\hline petiolaris D. C. & . . & . & $\mathbf{H}$ & 5 & HV \\
\hline Suchtelenia calycina C. A. M. & & & Th & 4 & $\mathrm{~V}$ \\
\hline Tournefortia sibirica L. . & 8 & & $\mathrm{G}$ & 7 & $\mathrm{HR}^{\star} \mathrm{V}$ \\
\hline Trichodesma incanum Bge. $\quad$. & & & $\mathrm{H}$ ? & 9 & $\mathrm{~V}$ \\
\hline Capparidaceae. & & & & & \\
\hline Capparis spinosa L. . & & & $\mathrm{Ch}$ & $6-7$ & $\mathrm{v}$ \\
\hline Cleome Raddeana Trautv. . . & & & Th? & 5 & $\mathbf{E}$ \\
\hline
\end{tabular}

1) biennial. 


$\begin{array}{cccc}\text { Growth- } & \text { Flowering- } & \text { Distri- } \\ \text { form } & \text { month } & \text { bution }\end{array}$

\section{Caryophyllaceae.}

Acanthophyllum Borsezowii Litw. . . . Ch?

- elatius Bge . $\mathrm{Ch}$

- glandulosum Bge. . . Ch

- Korolkowi Rgl. \& Schm. . Gh

- paniculatum $\mathrm{Rgl}$. . $\mathrm{Ch}$ ?

- pungens (Bge.) Bois. . . Ch

Ch

stenostegium Freyn \& Sint, . Ch

Arenaria serpyllifolia L, . . . . $\quad$ Th

Dianthus angulatus Royle . . . . . . H

- crinitus Sm. . . . : . . H

Gypsophila alsinoides Bge. . . . . . . Th

- elegans M. B. . . . $\quad$ Th

- spathulifolia F.\&M. . Th

- tríchotoma Wendl. . . . H

Herniaria diandra Bge. . . . . . Th

Holosteum liniflorum Stev. . . $\mathrm{Th}^{1}$ umbellatum L. . . Th

Saponaria parvula Bge. . . Th

Silene nana Kar. Kir. . . . . . Th

- odoratissima Bge. . Ch

- Olgae Rgl. \& Schm. H?

- suffrutescens M. B. . Ch

- turkestanica Rgl. \& Schm. H?

Spergularia diandra (Guss.) . . . Th

- salina Prẹsl. . . . . . . . Th

Ceratophyllaceae.

Ceratophyllum demersum L. . . . . $\mathrm{HH} \quad 6$ ? $\mathrm{H}^{\star} \mathrm{R}^{\star} \mathrm{V}^{\star}$

Chenopodiaceae.

Agriophyllum arenarium M. B. . Th

$\begin{array}{cc}6 ? & \text { HRV } \\ 6-8 & \text { V } \\ 6-7 & \text { E } \\ 7 ? & \text { E } \\ 7-8 & \text { HRV } \\ ? & \text { HV } \\ 5 & \text { H } \\ 5 & \text { H } \\ 5 & \text { E } \\ 6-8 & \text { HRV }\end{array}$

- salsa (C. A. M.) . . . . . . . . Ch

$\begin{array}{llll}\text { - } & \text { latifolium F.\& M. } & \text {. . } & \text { Th } \\ \text { - } & \text { minus F.\& M. . . } & & \text { Th }\end{array}$

Anabasis aphylla

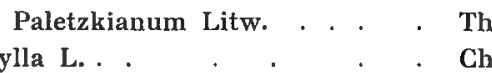

- brachiata Bge. . . $\mathrm{H}$

- eriopoda (C. A. M.) . . . . . H

- hispidula Bge. . . , H

- jaxartica Bge. . . . . . . H?

Arthrophytum subulifolium Schrenk. . Ch

Atriplex dimorphostegium Kar. Kir. . Th

6 ? H

- laciniatum L. . . . . . . . . Th

$5 \quad H V$

$5 \quad \mathrm{H}^{\star} \mathrm{R}^{*} \mathrm{~V}^{\star}$

1) biennial. 


\begin{tabular}{|c|c|c|c|c|c|c|}
\hline Name & & & & $\begin{array}{l}\text { Growth- } \\
\text { form }\end{array}$ & $\begin{array}{l}\text { Flowerlng- } \\
\text { month }\end{array}$ & $\begin{array}{l}\text { Distri- } \\
\text { butlon }\end{array}$ \\
\hline Atriplex serpyllifolium Bge. & . . & & & Th & $?$ & H \\
\hline turcomanicum F. \& M. & . & ". & $\cdot$ & Th & $\mathbf{5}$ & V \\
\hline verruciferum M. B. . & . & & . & Ch? & $?$ & HRV \\
\hline Bassia hirsuta (Nolte) Volk. . . & . & & . & Th & $5 ?$ & HRV \\
\hline 一 hyssopifolia (Pall.) . . . & 1 & & . & Th & $5 ?$ & HRV \\
\hline - latifolia (Fres.) . . . & & " & & Th & $4-5$ & $\mathrm{~V}$ \\
\hline 一 sedifolia (Pall.). . . . & . & . & . & Th & 5 & $H R^{\star} V$ \\
\hline Bienertia cycloptera Bge. . . & . & & & Th & $?-8$ & $\mathrm{v}$ \\
\hline Borszcowia aralo-caspica Bge. & & & & Th & $7 ?$ & $\mathbf{E}$ \\
\hline Ceratocarpus arenarius L. & & & & Th & 5 & $\mathrm{HR}^{*} \mathrm{~V}$ \\
\hline Corispermum hyssopifolium L. & & & . & Th & $6-7$ & $\mathrm{H}^{\star} \mathrm{RV}$ \\
\hline laxiflorum Schrenk. & & & & Th & 6 & $\mathrm{HR}$ \\
\hline Lehmannianum Bge. & & & & Th & $7 ?$ & $\mathbf{E}$ \\
\hline nitidum Kit. . . & . & & . & Th & $6 ?$ & $\mathrm{HR}^{\star} \mathrm{V}$ \\
\hline orientale Lam. . & & & & Th & $7 ?$ & HRV \\
\hline Cornulaca Korschinskyi Litw. . & . & & & Th & 9 & $\mathrm{E}$ \\
\hline Girgensohnia diptera Bge. . . & & & & Th & $6-7 ?$ & $\mathbf{E}$ \\
\hline - $\quad$ oppositiflora Pall. & . & & & Th & 8 & HRV \\
\hline Halanthium gamocarpum (Moq.) & & . & & Th & $6-8$ & $\mathrm{v}$ \\
\hline Lipskii Pauls. & & & & Th & 8 & $\mathbf{E}$ \\
\hline - ovinum Bge. & & & & Th? & $7 ?$ & $\mathbf{E}$ \\
\hline Halimocnemis Karelini Moq. . . & & & & Th & 7 & HR \\
\hline - $\quad$ macranthera Bge. & & & & Th & $6-7$ & $\mathbf{E}$ \\
\hline pilosa Moq. & & & & Th & 7 & $\mathrm{v}$ \\
\hline villosa Kar. Kir. & & & & Th & $6-7$ & $\mathbf{H}$ \\
\hline Halocharis hispida C. A. M. & . & & & $\mathrm{Th}$ & $6-7 ?$ & HV \\
\hline Halocnemum strobilaceum (Pall.) $\mathrm{M}$ & M. B. & & & F & $7-8$ & $\mathrm{HRV}^{*}$ \\
\hline Halogeton glomeratus C. A. M. . . & . . & & 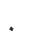 & Th & $7 ?$ & $H^{\star} \mathrm{RV}$ \\
\hline Halopeplis pygmaea (Pall.) Bge. & & & . & Th & $5 ?$ & HRV \\
\hline Halostachys caspica (Pall.) C. A. M. & & & & F & $6-7$ & HRV \\
\hline Haloxylon Ammodendrom (C. A. M.) & & ge. & . & $\mathrm{F}$ & 6 & $\mathrm{HV}$ \\
\hline Horaninowia juniperina C. A. M. . & & & & Th & 7 & $\mathrm{RV}$ \\
\hline - ulicina F.\& M. & . . . & . & & $\mathrm{Th}$ & $7-8$ & HR \\
\hline Kalidium caspicum L. . . & . . & . & & Ch? & $7-8$ & HRV \\
\hline - foliatum Pall. & . & . & & Ch? & $7 ?$ & HR \\
\hline Kirilowia eriantha (Kar. Kir.) Bge. & . & . & & Th & 5 & HV \\
\hline Kochia prostrata Schrad. & & - & & Ch & $4-8$ & $H^{\star} R^{\star} V$ \\
\hline - stellaris Moq. & · & & & Th & 5 & $\mathrm{H}^{*} \mathrm{~V}$ \\
\hline Nanophytum erinaceum Pall. & . & & & $\mathrm{Ch}$ & $7 ?$ & HR \\
\hline Noëa spinosissima $L$. & & & & $\mathrm{Ch}$ & $7-10$ & $\mathrm{~V}^{*}$ \\
\hline Panderia pilosa F. \& M. & & & & Th & 7 & HRV* \\
\hline Petrosimonia brachiata (Pall.) Bge & & & & Th & $7 ?$ & HRV \\
\hline Piptoptera turkestana Bge. . . . & & - & & Th & $7 ?$ & $\mathbf{E}$ \\
\hline Salicornia herbacea L. & & • & & Th & $7 ?$ & $\mathrm{HR}^{\star} \mathrm{V}^{\star}$ \\
\hline Salsola Androssowi Lity & . & & & Th & 9 & $\mathbf{E}$ \\
\hline
\end{tabular}




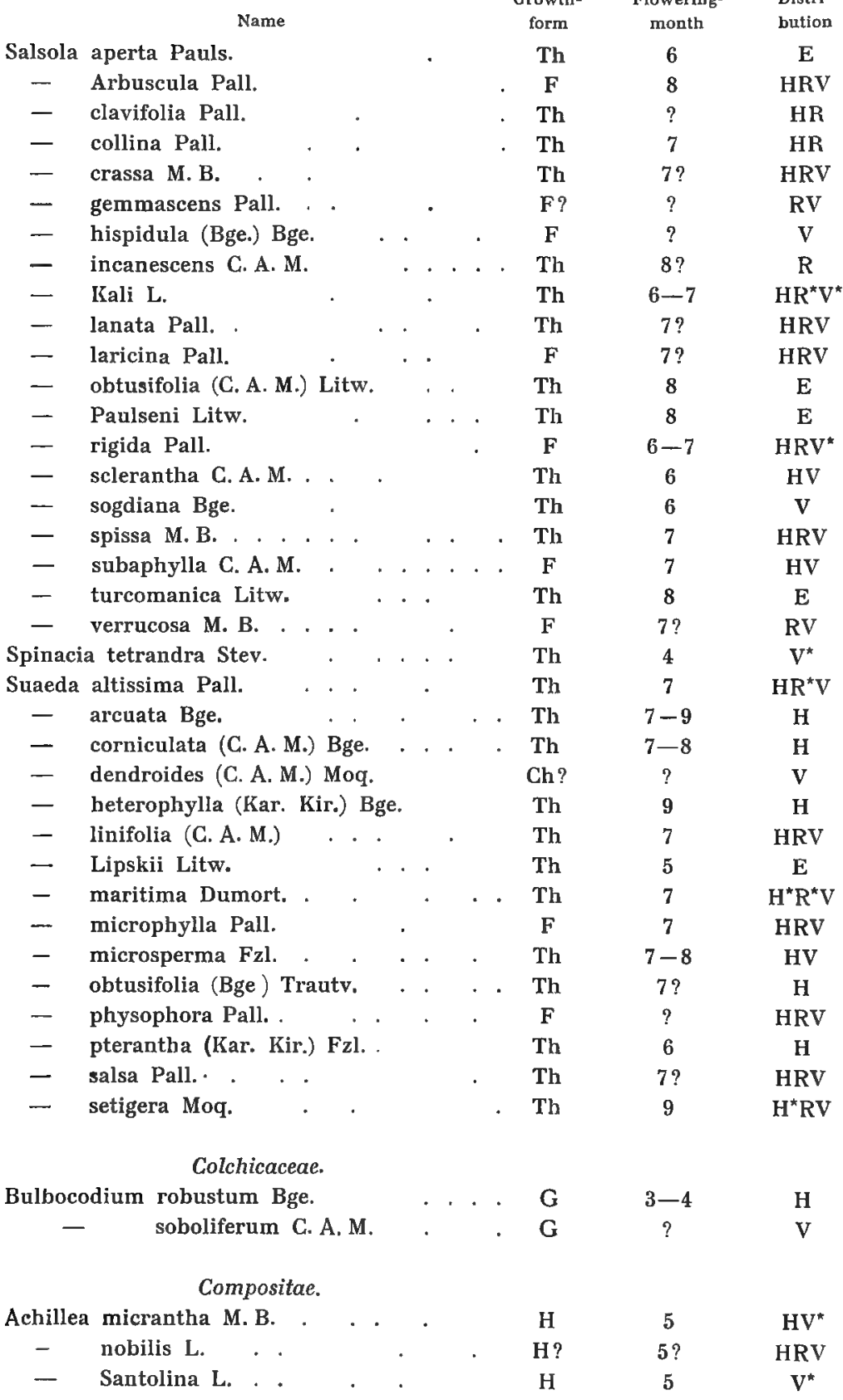




\begin{tabular}{|c|c|c|c|c|c|c|c|c|}
\hline \multicolumn{6}{|c|}{ Name } & $\begin{array}{l}\text { Growsh- } \\
\text { form }\end{array}$ & \multirow{2}{*}{$\begin{array}{c}\text { Flowering- } \\
\text { month } \\
\mathbf{5}\end{array}$} & \multirow{2}{*}{$\begin{array}{l}\text { Distri- } \\
\text { bution } \\
\text { HRV }\end{array}$} \\
\hline Acroptilor & n Picris (Pall.) & & . & . & . & G & & \\
\hline Anthemis & altissima & . & & . & & Th & 5 & $\mathrm{RV}^{\star}$ \\
\hline Artemisia & Absinthium $\mathrm{L}$. & . & & & & $\mathrm{H}$ & $7-8$ & $H R^{\star} \mathrm{V}$ \\
\hline - & annua L. . & 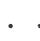 & . . & & . & Th & $8-9$ & $\mathrm{HRV}^{\star}$ \\
\hline - & Cina Berg & & . . & . & & Ch & $8 ?$ & $\mathbf{E}$ \\
\hline- & eriocarpa Bge. & & . & . & . & $\operatorname{Ch} ?$ & 4 & $\mathrm{v}$ \\
\hline - & herba alba Ásso & . & . . & 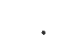 & . & . $\mathrm{Ch}$ & 9 & $H^{\star} V^{\star}$ \\
\hline- & maritima L. (var. di & v.) & . . & . & . & Ch & 9 & $H^{\star} R^{\star} V$ \\
\hline- & procera Willd. . & & & $\cdot$ & . & $F ?$ & $?$ & $H^{*} V$ \\
\hline- & scoparia W. K. . & & & & . & . Th & $6 ?$ & $\mathrm{HR}^{*} \mathrm{~V}$ \\
\hline - & serotina Bge. & . & . . & & & . $\mathrm{Ch}$ & 9 & $\mathrm{E}$ \\
\hline - & songorica Schrenk. & . & . & . & . & Ch & $5 ?$ & $\mathrm{H}$ \\
\hline - & vulgaris $\mathrm{L}$. & &. & . & . & $\mathbf{H}$ & 8 & HRV \\
\hline Aster alta & aicus $\mathrm{w}$. & & . . & . . & . & . $\mathrm{Ch}$ & $5 ?$ & $\mathbf{H}$ \\
\hline - trip & polium L. & . & . & . & . & $\mathbf{H}$ & $7 ?$ & $\mathrm{HR}^{\star} \mathrm{V}$ \\
\hline Carduus $t$ & tenuiflorus Sm. . . & . & . & . & & Th & $?$ & $\mathrm{~V}$ \\
\hline Calendula & persica C.A.M. . & & & . & . & Th & $?$ & $\mathrm{~V}^{*}$ \\
\hline Carthamu & is oxyacantha M. B. . & . & & & & Th & 7 & $\mathrm{HV}$ \\
\hline Centaurea & a albispina (Bge.) & . & . & . & . & Th & 5 & $\mathbf{E}$ \\
\hline- & depressa M. B. & . & . . & & & Th & 4 & $\mathrm{~V}^{*}$ \\
\hline - & iberica Trev. & & 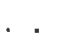 & . & . & $\mathbf{H}$ & 7 & $V^{\star}$ \\
\hline- & moschata L. & . & & & 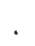 & Th & 5 & $\mathrm{~V}$ \\
\hline - & phyllocephala Bois. & . & & & & Th & 5 & $\mathrm{~V}$ \\
\hline - & pulchella Ldb. . & . & . & . & . & Th & 4 & HRV \\
\hline Chardinia & xeranthemoides Des & & . & & & Th & 4 & $\mathrm{~V}^{*}$ \\
\hline Chrysanth & hemum achilleifolium & $(\mathbf{M}$ & I. B.) & $\mathrm{Kz}$ & & $\mathrm{H}$ ? & $?$ & $\mathrm{R}$ \\
\hline Cousinia & affinis C. A. M. & & & . . & . & $\left.\mathbf{H}^{\mathbf{1}}\right)$ & 6 & $\mathrm{H}$ \\
\hline- & alata C. A. M. & & & . & . & $\left.\mathrm{H}^{1}\right)$ & 7 & $\mathrm{H}$ \\
\hline - & annua Winkl. . & & & • & & Th & 6 & $\mathbf{E}$ \\
\hline- & Antonowii Winkl. & & & & . & $\mathrm{H}$ ? & $?$ & $\mathrm{E}$ \\
\hline - & aralensis Bge. . & & & & & $\mathrm{Th}$ & 5 & $\mathrm{E}$ \\
\hline - & Beckeri Trautv. & & . & & & $\mathrm{H}$ & $?$ & $\mathbf{E}$ \\
\hline - & bipinnata Bois. & . & & & . & $\left.\mathrm{H}^{1}\right)$ & 5 & $\mathrm{v}$ \\
\hline - & caesia Winkl. & . & . & & & $\left.\mathrm{H}^{1}\right)$ & 5 & E \\
\hline - & decurrens Rgl. & . & & & & $\mathrm{H}$ ? & 5 & $\mathrm{v}$ \\
\hline - & dichotoma Bge. & . & & & & $\mathrm{Th}$ & 7 & $\mathrm{E}$ \\
\hline - & dissecta Kar. Kir. . & & . & & & $\left.\mathrm{H}^{1}\right)$ & 7 & $\mathrm{v}$ \\
\hline- & lepida Bge. & $\cdot$ & & . & & H? & $?$ & $\mathrm{v}$ \\
\hline - & microcarpa Bois. & & & & . & $\left.\mathrm{H}^{1}\right)$ & $\mathbf{5}$ & $\mathrm{V}$ \\
\hline - & minuta Bois. . & & & . & . & Th & 5 & $\mathrm{~V}$ \\
\hline- & mollis C. A. M. & & & & & $\left.\mathrm{H}^{1}\right) ?$ & $4 ?$ & $\mathrm{H}$ \\
\hline - & onopordioides Ldb. & & & & & $\left.\mathrm{H}^{1}\right)$ & $?$ & $\mathrm{~V}$ \\
\hline- & platylepis C. A. M. & & & & & $\left.\mathrm{H}^{1}\right)$ & 7 & $\mathrm{H}$ \\
\hline
\end{tabular}

1) biennial. 


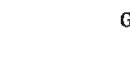

Cousinia pusilla Winkl.

Growth-
form

Flowering-
month

Distri-

form

- Raddeana Wink

$\mathrm{H}$ ?

- Regeli Winkl.

- tenella F. \& M.

$\mathrm{H}$

$?$

bution

- triflora C. A. M.

Th

$\mathrm{H}^{1}$ )

- xiphiolepis Bois. . . . . $\mathbf{H}$

Crupina vulgaris Cass. . . . Th

Dipterocoma pusilla F. \& M. . Th

Echinops jaxarticus Bge. $\mathrm{H}$ ?

Evax filaginoides Kar. Kir. . . . Th

Garhadiolus Hedypnois F. \& M. . Th - papposus Bois. \& Buhse . . . T Th

Helichrysum plicatum D. C. H

Heteracia Szovitsii F.\& M. . . . . Th

Heteroderis pusilla Bois. Th

Inula caspica Blum. . $\quad \mathrm{H}^{1}$ )

- divaricata Cass. . . Th

Jurinea adenocarpa Schrenk . . H ?

- chaetocarpa (Ldb.), Bois. H

- derderioides Winkl. . . H

- Korolkowi Rgl. Th

- Lehmanni (Bge.) . . . . Th

- linearifolia (D. C.) Bong. . Ch

- Pollichii D. C. . . . H

Koelpinia linearis Pall. . . $\mathrm{Th}$

Lachnophyllum gossypinum Bge. . . Th

Lactuca canescens Rgl. \& Schm. . . Th

- persica Bois. . . . . . $\mathbf{H}^{\mathbf{}}$ )

- undulata Ldb. . . . . . Th

Lagoseris obovata Bois. . . . . Th

Launaea nudicaulis (L.) Hook. . . . . . . . H

Leontodon asperrimum (Willd.) . . . $\mathrm{H}$

Matricaria lamellata Bge. . . . . . . . . Th

- lasiocarpa Bois. . . . . . . Th

Micropus erectus L. . . . . . . , Th

Mulgedium tataricum D. C. . . . G

Pluchea caspica (Pall.) Hoffm. G?

Pterotheca aralensis Bge. . . . . . . $\mathrm{H}$

Rhaponticum nitidum Fisch..... . H?

Saussurea salsa (Pall.) Spreng. . . . . . H

Scorzonera acrolasia Bge. . . . . . . . Th

- ammophila Bge. . . . Th

Th

cenopleura Bge. , . . . . . . Th

$5 \quad \mathrm{E}$

$5 \quad \mathrm{E}$

? $\quad \mathrm{V}$

$5 \quad \mathrm{H}$

? $\mathrm{V}$

$5 \quad$ HRV

5 V

7 E

? $\mathrm{R}$

$5 \quad \mathrm{~V}^{*}$

? $\mathrm{V}$

? $\quad \mathrm{V}^{\star}$

$4 \mathrm{HV}$

4-5 V

7 HR

6 V

$5 \quad$ H

$5 \quad$ HR

$6 \quad \mathrm{E}$

? $\quad \mathrm{E}$

$4 \quad \mathrm{H}$

? $\quad \mathrm{HR}^{*}$

$6 \quad \mathrm{HR}^{\star} \mathrm{V}$

4-5 $\mathrm{HRV}^{*}$

8-9 E

$? \quad \mathrm{E}$

5 V

$4 \mathrm{HRV}^{*}$

4 HRV

4-5 V

$5 \quad \mathrm{~V}^{\star}$

4 E

4 V

? $\mathrm{HV}^{*}$

$5-6 \quad H^{\star} R^{\star} V$

7-9 HR

4-5 E

5 ? E

$7-8 \quad H^{*} \mathrm{R}$

4 E

5 E

4 E

1) biennial. 


$\begin{array}{cccc} & \text { Growth- } & \text { Flowering- } & \text { Distri- } \\ \text { Name } & \text { form } & \text { month } & \text { bution }\end{array}$

Scorzonera ensifolia M. B. . . . H $\quad$ H? HR

- hemilasia Bge. . Th

- intermedia Bge. . . . . . Th

4-5 E

- ovata Trautv. . H ?

- pusilla Pall. . . . . $\mathrm{H}$

- Raddeana Winkl. . . . . H

- stricta Horn. . . . H H

- tuberosa Pall. . H H

Senecio dubius Ldb. . . Th

- subdentatus Ldb. . . . . Th

Taraxacum glaucanthum D. C. . . . . . H

Tragopogon brevirostre D.C. . . . . $\mathbf{H}^{\mathbf{1}}$ )

$\left.\mathrm{H}^{1}\right) \quad 5 \quad \mathrm{H}^{\star} \mathrm{RV}$

- majus Jacq. . . . . . $\mathbf{H}^{\left.{ }^{1}\right)}$

4 E

5 ? $\mathrm{E}$

$4-5$ HRV

5 E

$4 \quad H^{\star} R$

$4 \quad \mathrm{E}$

$6 ? \quad \mathrm{HR}$

$4 \mathrm{HV}$

Zollikoferia acanthodes Bois. .

\section{Convolvulaceae.}

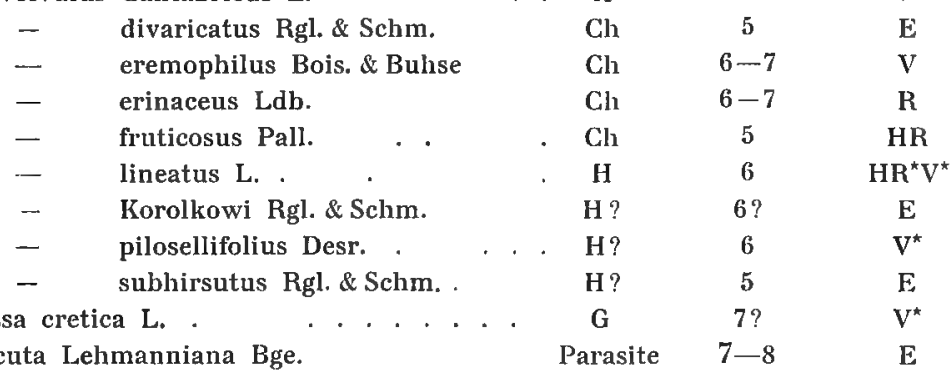

Cuscuta Lehmanniana Bge.

\section{Cruciferae.}

Alyssum dasycarpum Steph. Th

- linifolium Steph. . . . . . Th

- marginatum Steud. . . . . . Th

- minimum W. . . . . . Th

Brassica Tournefortii Gouan. $\mathrm{Tl}$

Camelina microcarpa Andrz. . . . . Th

Capsella procumbens (L.) Fr. . . Th

Chartoloma platycarpum Bge. . . . Th

Clorispora tenella (Pall.) D. C. . . Th

Cithareloma Lehmanni Bge. . . $\mathrm{Tl}$ vernum Bge. . $\quad$ Th

Crambe Kotschyana Bois. $\quad \mathrm{Tl}$

Cryptospora falcata Kar. Kir. . $\mathrm{Tl}_{\mathbf{l}}$

Diptychocarpus strictus (Fisch.) Trautv. Th

$H R V$
$H R^{*} V$
$V$
$H R^{\star} V^{\star}$
$V^{\star}$
$H R^{\star} V$
$H^{\star} V^{\star}$
$E^{\star}$
$H R^{\star} V^{\star}$
$E$
$E$
$V$
$H R$
$H R V$

1) biennial, 
Euclidium syriacum

(L) R. Br,

Th

- tenuissimum (Pall.) Fedtsch.

Th

Goldbachia laevigata (M. B.) D. C.

4

4

$\mathrm{HR}^{*} \mathrm{~V}^{*}$

Hymenophysa pubescens C. A. M.

$4-5$

$\mathbf{R}$

$\mathrm{Th}$

7 ?

$\mathrm{H}^{*} \mathrm{RV}$.

Isatis Armena L.

Th

- emarginata Kar, Kir.

Th

- minima Bge.

Th

- turcomanica Korsh.

Lachnoloma Lehmanni Bge.

Th

Lepidium Draba L.

H

- obtusum Bois.

$\mathrm{H}$ ?

- repens (Schrenk) Bois.

Leptaleum filifolium (W.) D. C.

Malcolmia africana $\mathrm{R}$. $\mathrm{Br}$.

$\mathrm{H}$ ?

Th

- brevipes (Kar. Kir.) Bois.

$\mathrm{Th}$

- Bungei Bois.

Th

- circinnata (Bge.) Bois.

- scorpioides (Bge.) Bois.

4

$\mathrm{H}$

$4-5$

V

$4-5$

HR

5

HRV

5

E

HRV

4

$\mathrm{HR}^{\star} \mathrm{V}^{\star}$

6

$\mathrm{R}$

$4-5$

$\mathrm{RV}$

4

$\mathrm{HRV}^{\star}$

HRV

4

HRV

Th

Th

Th

$$
\text { - turkestanica Litw. }
$$

Matthiola chenopodiifolia F. \& M.

- Stoddarti Bge. . . . .

Th

Octoceras Lehmannianum Bge. .

Tlı

Pachypterygium lamprocarpum Bge. $\quad \mathrm{Tl}_{\mathrm{l}}$

Peltaria turkmena Lipsky

Sisymbrium junceum M. B.

- pumilum Steph.

- runcinatum Lag.

Th

-- Sinapistrum Crz.

$\mathrm{Th}^{\mathbf{1}}$ )

- sumbarense Lipsliy

Th

- toxophyllum (M. B.) C. A. M. . Th

- Trautvetteri Lipsky

Th

Spirorhynchus sabulosus Kar. Kir.

Th

Streptoloma desertorum Bge. .

Syrenia siliculosa (D C.) Andrz.

\section{Cucurbitaceae.}

Echallium Elaterium (L.) Rich. 
$\begin{array}{cccc}\text { Growth- } & \text { Flowering- } & \text { Distrl- } \\ \text { form } & \text { month } & \text { bution }\end{array}$

Cyperaceae.

Carex paludosa Good.

- physodes M. B.

HH 5 ? $\mathrm{HR}^{*} \mathrm{~V}$

- stenophylla Wbg.

H $3-4$ HRV

Cyperus fuscus $\mathrm{L}$.

H

Th

$4-5$

$H^{*} R^{*} V^{*}$

- longus L. .

$\mathrm{HH}$

6 ?

$\mathrm{HR}^{*} \mathrm{~V}^{*}$

- rotundus $\mathrm{L}$

$\mathrm{HH}$

5 ?

$R V^{\star}$

Heleocharis argyrolepis Kier. palustris $\mathrm{R}$. Br.

$\mathrm{HH}$

Schoenus nigricans $\mathrm{L}$.

Scirpus hamulosus Stev.

- littoralis Schrad.

$\mathrm{HH}$

- maritimus L.

$\mathrm{HH}$

- Tabernaemontani Gm.

$\mathrm{HH}$

Dipsacaceae.

Scabiosa Olivieri Coult.

Elaeagnaceae.

Elaeaguus hortensis M. B.

\section{Equisetaceae.}

Equisetum ramosissimum Desf.

Euphorbiaceac.

Andrachne telephioides L.

Crozophora gracilis F.\& M.

$\begin{array}{cc}5 & \mathrm{~V}^{*} \\ 7 ? & \mathrm{H} \\ ?-7 & \mathrm{~V}^{*} \\ 6 ? & \mathrm{H} \\ 6-7 & \mathrm{~V} \\ ? & \mathrm{HV} \\ 6 ? & \mathrm{HR}^{*} \mathrm{~V} \\ 4-5 & \mathrm{R} \\ ? & \mathrm{~V} \\ 5 & \mathrm{H} \\ 4 & \mathrm{E}\end{array}$

\section{Frankeniaceae.}

Frankenia hirsuta L. . . . . . . Gh

6-7 $\mathrm{HR}^{\star} \mathrm{V}^{\star}$

Fumariaceae.

Corydalis Schangini (Pall.) Fedtsch. . . . G

$\begin{array}{cc}5 ? & \mathrm{H} \\ 4 & \mathrm{H} \\ 3-4 & \mathrm{HR}^{*} \mathrm{~V}^{*}\end{array}$

Fumaria Vaillantii Lois 


$\begin{array}{cccc}\text { Name } & \text { Growth- } & \text { Flowering- } & \text { Distri- } \\ \text { form } & \text { month } & \text { bution }\end{array}$

Gentianaceae.

Erythraea pulchella Fr.

Gentiana Olivieri Gris.

Geraniaceae.

Erodium bryoniaefolium Bois.

$$
\text { - ciconium } \mathbf{L} \text {. }
$$

Th $\left.{ }^{1}\right)$

- Hoefftianum

- oxyrrhynchum $M$

$4-5$
4
4
4
5

$V^{*}$

$V^{*}$

$\mathrm{R}$

$\mathrm{V}$

$\mathrm{HV}^{*}$

\section{Gnetaceae}

Ephedra alata Dene. distachya L. .

F

Ch

$4-5$

5

$\mathrm{V}^{*}$

HRV

\section{Gramineae.}

Aeluropus littoralis Parl. repens Parl.

G

G

Agropyrum squarrosum Link . . $\quad$ Th

Apera interrupta Beauv, . . . . . Th

Aristida arachnoidea Litw, . . . . G ?

$$
\text { - pennata Trin . . . G }
$$

Avena sterilis L. ... . . Th

Boissiera bromoides Hochst. \& Steud. . Th

Bromus crinitus Bois, . . Tl

- Danthoniae Trin. . . . $\quad$ Th

- oxyodon Schrenk . Th

- tectorum L $\mathbf{L} \quad$... Tl

Calamagrostis pseudophragmites Baumg. G

Crypsis aculeata Ait.

Th

- Borszowii Rgl.

Th

Danthonia Forskalei Trin. . , , H

Elymus aralensis Rgl.

sabulosus M. B. "

Erianthus Ravennae L. ." . . H

Festuca ciliata Danth. . . . . . , . Th

Hordeum rrinitum Desf. . . . . Th

- maritimum W. . . . Th

- murinum L.

- secalinum Schreb.

Imperata cylindrica P. B.

H

$\mathrm{H}$

Koeleria phleoides Pers.

Th

Lasiagrostis splendens Kth.

$\begin{array}{cc}5-6 & \mathrm{HRV} \\ 5 & \mathrm{RV} \\ 4 & \mathrm{~V}^{\star} \\ 5 & \mathrm{RV} \\ 5-6 & \mathrm{E} \\ 5-6 & \mathrm{HV} \\ 5 ? & \mathrm{RV} \\ 5 & \mathrm{H}^{\star} \mathrm{V}^{\star} \\ 5 & \mathrm{H}^{\star} \mathrm{V} \\ 5 & \mathrm{~V} \\ 4-5 & \mathrm{HR} \\ 4-5 & \mathrm{R}^{\star} \mathrm{V}^{\star} \\ 6 & \mathrm{H}^{\star} \mathrm{RV} \\ 5 ? & \mathrm{R}^{\star} \mathrm{V}^{\star} \\ 5 ? & \mathrm{E} \\ 5 & \mathrm{~V}^{\star} \\ 6 & \mathrm{E} \\ 5 & \mathrm{R} \\ 6 & \mathrm{~V}^{\star} \\ 5 & \mathrm{~V}^{\star} \\ 4-5 & \mathrm{~V} \\ 5 & \mathrm{HRV} \\ 5 & \mathrm{RV} \\ 5 & \mathrm{H}^{\star} \mathrm{RV} \\ 5 & \mathrm{H} \\ 4 & \\ 6 ? & \end{array}$

1) or blennial $(\mathrm{H})$. 


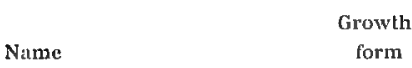

Flowering- Distri-

Lepturus hirtulus Rgl. . . . . . . . Tl

Th

Nardurus maritimus (L.) Hack. . . Th

Panicum crus galli L. . . . . . . . . ${ }^{\mathrm{T}} \mathrm{Th}$

Pappophorum persicum Bois. . . . . . . H

Phragmites communis Trin. . . . . G

Poa bulbosa L. (vivipara) . . . . . . . . $\mathbf{H}$

Saccharum spontaneum L. . . . . . . G?

Schismus minutus Rgl. \& Schm. . . . . Th

month bution

Sclerochloa dura Beauv. . . . . Th

Secale fragile M. B. . . . . $\mathrm{Th}$

Stipa Lessingiana Trin. . . . . . H

— Szovitsiana Trin. . . . . . . H

Trisetum Gaudinianum Bois. . . . . Th

Triticum Aegilops Beauv. . . . . . . . . Th

- desertorum Fisch. . . . . . H?

- orientale M. B. . . . . . . . . . Th

— pumilum Steud. . . . . . . . Th

Haloragidaceae.

Myriophyllum spicatum L. . . . . . $\mathrm{HH}$

Hydrocharidaccae.

Vallisneria spiralis L. . . . . . . . HH

RV

Iridaceae.

Iris caucasica Hoffm. . . . . . . . . G

$\begin{array}{cc}4 & \mathrm{~V} \\ 5 & \mathrm{HRV} \\ 3 & \mathrm{~V} \\ 5 ? & \mathrm{E} \\ 5 ? & \mathrm{HR}^{\star} \mathrm{V} \\ 4 & \mathrm{R} \\ 3-4 & \mathrm{HV} \\ 5 ? & \mathrm{HR}\end{array}$

\section{Juncaceae.}

Juncus acutus L. (var. littoralis Trautv.). . . H

$\begin{array}{cc}6 ? & \mathrm{~V}^{*} \\ 4-5 ? & \mathrm{HR}^{*} \mathrm{~V}^{*} \\ 5 ? & \mathrm{R}^{*} \mathrm{~V} \\ 5 ? & \mathrm{HR}^{*} \mathrm{~V}^{*} \\ 5 ? & \mathrm{H}^{*} \mathrm{R}^{*} \mathrm{~V}^{*}\end{array}$

\section{Labiatae.}

Chamaesphacos ilicifolius Schrenk .... Th

Eremostachys aralensis Bge. . . . . . H

$\begin{array}{cc}5-6 & \mathrm{H} \\ 5 & \mathrm{HV}\end{array}$

desertorum Rgl. . . . . . $\mathrm{H}$ ? 
Name

Growth -

Flowering-

Distri-

form

month

Eremostachys labiosa Bge. .

$\mathrm{H}$

5

- molucelloides Bge. . $\quad \mathrm{H}$

5 ?

bution

- paniculata Rgl.

$H$ ?

- transoxana Bge. . . .

$\mathbf{H}$

- tuberosa Bge.

H

- uniflora Rgl.

$\mathrm{H}$ ?

Hypogomphia turkestana Bge. . Th

Lagochilus acutilobus Bge. . . . . . H

- inebrians Bge. . . . $\mathrm{H}$ ?

Th

Lallemantia Royleana Bth.

Th

Lycopus europaeus L. . . $\mathrm{HH}$

Mentha longifolia Huds. (subsp. Royleana Briq.). HH

Nepeta micrantha Bge.

Th

Perowskia abrotanoides Kar. . . . . . Ch?

Phlomis thapsoides Bge. . . H H

Tapeinanthus persicus Bois. . Th

Ziziphora tenuior L. . . . . . Th

Lemnaceae.

Lemna minor L. . . . . . . . . . $\mathrm{HH}$

$4-6$ ?

$\mathrm{HR}^{*} \mathrm{~V}^{*}$

- trisulca L.

. $\mathrm{HH}$

4 ?

$R^{*} V$

\section{Lentibulariaceae.}

Utricularia vulgaris $\mathrm{L}$.

$\mathrm{HH}$

$H^{\star} R^{*} V^{*}$

\section{Liliaceae.}

Allium Borszcowii (Rgl.) Lipsky . . . G G

- caspicum (Pall.) M. B. . . . G

- inderiense Fisch. ... . G

- Lehmannianum Merckl. . . G

- sabulosum Stev. . . G G

- Schuberti Zucc. . . . . . . . . . G

- tataricum L. . . . G

- Tschulpias (Rgl.) Lipsky. . . . G

Asparagus verticillatus L. . . . . . G

Eremurus anisopterus (Kar. Kir.) Rgl. . . G

- Capusii Frch. . . . G

- inderiense (Stev.) Rgl. . . . . G

- Olgae Rgl. . . . . . . . G

Eremurus velutinus Bois. \& Buhse . . G

Gagea chlorantha (M. B.) Schult. . G

- Liotardi Schult. . . . . G

- reticulata (Pall.) Schult. . . . . G

Rhinopetalum Karelini Fisch. . . . . . . G

stenantherum Rgl. . . . . . G

$\begin{array}{cc}4 & \mathrm{E} \\ 4-5 & \mathrm{HR} \\ 4-5 & \mathrm{R} \\ 5 & \mathrm{~V} \\ 5-6 & \mathrm{HR} \\ 4 & \mathrm{~V}^{*} \\ 4-5 & \mathrm{HRV} \\ 4-5 & \mathrm{E} \\ ? & \mathrm{HRV} \\ 4 & \mathrm{E} \\ 3 & \mathrm{E} \\ 4 & \mathrm{HR} \\ 7 & \mathrm{E} \\ 5 & \mathrm{~V} \\ 2-3 & \mathrm{~V}^{*} \\ 2-3 & \mathrm{~V}^{*} \\ 2-3 & \mathrm{H}^{*} \mathrm{~V}^{*} \\ 4-5 & \mathrm{HRV} \\ 4 & \mathrm{E}\end{array}$




\begin{tabular}{|c|c|c|c|c|c|c|c|c|}
\hline & Name & & & & & $\begin{array}{l}\text { Growth- } \\
\text { form }\end{array}$ & $\begin{array}{l}\text { Flowering- } \\
\text { month }\end{array}$ & $\begin{array}{l}\text { Distri } \\
\text { butior }\end{array}$ \\
\hline Tulipa & Androssowi Litw. & & . & . & & G & 3 & $\mathrm{E}$ \\
\hline - & biflora Pall. . . & ${ }^{\circ}$ & & & & G & $3--4$ & $\mathrm{RV}^{\star}$ \\
\hline - & chrysantha Bois. . & & . & . & & G & 3 & $\mathrm{Y}$ \\
\hline - & Greigi Rgl. & & 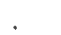 & & . & G & $4-5$ & $\mathrm{E}$ \\
\hline - & sogdiana Bge. & & . . & . & & G & $\mathbf{3}$ & $\mathbf{E}$ \\
\hline
\end{tabular}

\section{Lythraceae.}

Lythrum Salicaria L.

$\mathrm{HH}$

6-7 $\quad \mathrm{HR}^{*} \mathrm{~V}^{*}$

\section{Malvaceae.}

Alcea sulphurea Bois.

\section{Najadaceac.}

Najas major Roth.

Oenotheraceae.

Epilobium hirsutum L. .

Orchidaceae.

Limodorum turkestanicum Litw.

Orobancheaceae.

Cistanche ambigua (Bge.)

$\begin{array}{lcc}\left.\mathrm{G}^{1}\right) & 4-5 & \mathrm{E} \\ \left.\mathrm{G}^{1}\right) & 4-5 & \mathrm{E} \\ \left.\mathrm{G}^{1}\right) & 4-5 & \mathrm{E} \\ \left.\mathrm{G}^{1}\right) & 4-5 & \mathrm{E} \\ \left.\mathrm{G}^{1}\right) & 5 & \mathrm{H} \\ \left.\mathrm{G}^{1}\right) & 4 & \text { HRV }\end{array}$

Papaveraceae.

Glaucium elegans F. \& M.

Th

Hypecoum parviflorum Barb.

Papaver arenarium M. B.

\section{Papilionaceae.}

Alhagi Camelorum Fisch.

Ammodendron Conollyi Bge.

Chl

F

$6-7$

$\mathrm{HRV}^{*}$

E

\footnotetext{
1) or $\mathrm{Th}$.
} 


\begin{tabular}{|c|c|c|c|c|c|c|c|}
\hline \multicolumn{5}{|c|}{ Name } & $\begin{array}{l}\text { Growth- } \\
\text { form }\end{array}$ & $\begin{array}{l}\text { Flowering- } \\
\text { month }\end{array}$ & $\begin{array}{l}\text { Distri- } \\
\text { bution }\end{array}$ \\
\hline \multicolumn{3}{|c|}{ Ammodendrou Eichwaldii Ldb. } & . & . & F & 5 & $\mathrm{E}$ \\
\hline- & Karelini F. \& M. & & . & & $\mathbf{F}$ & 5 & V \\
\hline- & Lehmanni Bge. & & & & $\mathrm{F}$ & 5 & $\mathrm{R}$ \\
\hline- & Sieversii Fisch & & & & F & $5 ?$ & $\mathrm{E}$ \\
\hline \multicolumn{4}{|c|}{ Ammothamnus Lehmanni Bge. . } & & $\mathbf{F}$ & 4 & $\mathrm{E}$ \\
\hline \multicolumn{3}{|c|}{ Astragalus Alopecias Pall. . } & & & $\mathbf{H}$ ? & 5 & HV \\
\hline- & Ammodendron Bge. & & . & & $\mathbf{F}$ & 5 & $\mathrm{R}$ \\
\hline- & Ammodytes Pall. . . & & 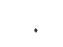 & . & $\mathrm{F}$ & 5 & HR \\
\hline- & ammophilus Kar. Kir & & & & Th & $4-5$ & $\mathrm{HV}$ \\
\hline - & ammotrophus Bge. & & & & $\mathrm{H}$ & 5 & $\mathbf{E}$ \\
\hline - & Androssowii Litw. & & & & $\mathbf{H}$ ? & 5 & $\mathrm{E}$ \\
\hline- & ankylotus F. \& M. . & & & & Th & $?$ & $\mathrm{R}$ \\
\hline - & arpilobus Kar. Kir. & & . & . & Th & 5 & $\mathbf{E}$ \\
\hline- & bakaliensis Bge. & & & & Th & 4 & $\mathrm{~V}$ \\
\hline- & Barrovianus Ait. \& Ba & ak. & & & $\mathbf{H}$ & 5 & $\mathbf{E}$ \\
\hline - & brachylobus Fisch. & & & & $\mathbf{F}$ & $5 ?$ & $\mathrm{HR}$ \\
\hline- & brachypus C. A. M. . & & & . & $\mathrm{F}$ & 5 & $\mathbf{E}$ \\
\hline- & campylorhynchos F. 8 & $\& \mathrm{M}$ & & & . $\mathrm{Tl}_{\mathrm{l}}$ & 4 & HV \\
\hline- & campylotrichus Bge. . & & . & . & . Th & 4 & $\mathbf{H}$ \\
\hline - & chaetodon Bge. & - & . & . & $\mathbf{H}$ & 5 & $\mathbf{H}$ \\
\hline- & chiwensis Bge. . . & & . . & . . & . $\mathrm{H}$ ? & $?$ & $\mathbf{E}$ \\
\hline- & commixtus Bge. . & . & & . . & . Th & 4 & $\mathrm{HV}^{*}$ \\
\hline - & contortuplicatus L. & . & . & & . Th & 5 & HRV \\
\hline - & corrugatus Bert. & . & . & . . & . Th & 4 & V \\
\hline- & Dianthus Bge. . . . & . . & . & & $\mathrm{Ch}$ & 5 & $\mathbf{E}$ \\
\hline- & eremospartoides Rgl. & . & . & . . & . $\mathrm{Ch}$ & 5 & $\mathbf{E}$ \\
\hline- & erioceras F.\& M. . . & . & . & . & $\mathbf{H}$ & $4-5$ & $\mathbf{R}$ \\
\hline- & farctus Bge. . & & . . & . . & $\mathbf{H}$ & 5 & $\mathbf{H}$ \\
\hline - & filicaulis F.\& M. & & . & . & Th & 4 & HV \\
\hline - & flexus Fisch. . . . & . & . & . & $\mathbf{H}$ & $4-5$ & HV \\
\hline - & grandiflorus Bge. & . & & . & . $\mathrm{H}$ ? & $4-5$ & $\mathbf{E}$ \\
\hline- & gyzensis Del. . & . . . & . & . & . $\mathrm{Th}_{\mathrm{h}}$ & 4 & $\mathrm{HV}^{\star}$ \\
\hline- & hyrcanus Pall. . & & & . & $\mathbf{F}$ & 5 & $\mathrm{E}$ \\
\hline - & karakugensis Bge. & & . & & $\mathbf{F}$ & $5-6 ?$ & $\mathrm{E}$ \\
\hline- & Lehmannianus Bge. & & . & & $\mathrm{H}$ ? & $4-5$ & $\mathrm{E}$ \\
\hline- & leiophysa Bge. & . . & . & & $\mathrm{H}$ ? & 5 & $\mathbf{E}$ \\
\hline- & longiflorus Pall. . & & & & $\mathbf{H}$ & $4 ?$ & HR \\
\hline- & macrocladus Bge. & $\cdot$ & . & . & $\mathbf{F}$ & 4 & $\mathbf{E}$ \\
\hline - & macronyx Bge. . . & & . & & $\mathbf{H}$ & $4-5$ & $\mathrm{E}$ \\
\hline - & macropus Bge. . & . & . . & . & $\mathrm{H}$ & $?$ & $\mathrm{HR}^{*}$ \\
\hline - & macrotropis Bge. . & & & . & $\mathrm{Ch}$ & $?$ & $\mathrm{H}$ \\
\hline - & mucidus Bge. . & ' & $\cdot$ & . & $\mathbf{H}$ & $4-5$ & $\mathrm{H}$ \\
\hline- & orbiculatus Ldb. & . & . . & & $\mathbf{H}$ & 5 & HV \\
\hline - & oxyglottis Stev. . & & $\cdot$ & & . $\mathrm{Th}$ & 5 & $\mathrm{RV}^{*}$ \\
\hline- & Pallassii Fisch. . & & & & $\mathbf{H}$ & $4-5$ & HR \\
\hline
\end{tabular}




\begin{tabular}{|c|c|c|c|c|c|c|c|}
\hline \multicolumn{5}{|c|}{ Name } & $\begin{array}{l}\text { Growth- } \\
\text { form }\end{array}$ & \multirow{2}{*}{$\begin{array}{c}\text { Flowering- } \\
\text { month } \\
4\end{array}$} & \multirow{2}{*}{$\begin{array}{c}\text { Distri- } \\
\text { bution } \\
\text { H }\end{array}$} \\
\hline Astragalus & paucijugus C. A. M. & & & . & F & & \\
\hline - & Petunikowii Litw. & & . & & $\mathrm{H}$ & 5 & $\mathbf{E}$ \\
\hline - & salsugineus Kar. Kir & & . & & $\mathrm{H}$ ? & $4-5$ & $\mathrm{H}$ \\
\hline - & scabrisetus Bong. & & & & $\mathrm{H}$ & 5 & $\mathrm{H}$ \\
\hline 一. & Schmalhausenii Bge. & & & & Th & 5 & $\mathrm{E}$ \\
\hline 一 & Schrenkianus F.\& M & & & & $\mathrm{H}$ & 4 & $\mathrm{H}$ \\
\hline - & scleroxylon Bge. & . & & . & $\mathrm{F}$ & $4-5$ & $\mathrm{E}$ \\
\hline 一 & sesamoides Bois. & . & & . & Thl & 4 & $\mathrm{HV}$ \\
\hline- & sogdianus Bge. & & & . & $\mathrm{H}$ & 5 & $\mathrm{H}$ \\
\hline - & sphaerophysa Kar. I & Rir. & ${ }^{\circ}$ & & $\mathrm{H}$ ? & 5 & $\mathrm{H}$ \\
\hline- & squarrosus Bge. & & & & $\mathrm{F}$ & 4 & V \\
\hline- & subbijugus Ldb. & & & & . $\mathrm{Ch}$ ? & $4-5$ & $\mathrm{H}$ \\
\hline- & tetrastichus Bge. . & . & & . & $\mathrm{H}$ & 5 & $\mathrm{E}$ \\
\hline- & tribuloides Del. . & . & & & Th & 5 & $H V^{*}$ \\
\hline - & turbinatus Bge. & & . & . & $\mathrm{H}$ ? & 5 & $\mathrm{~V}$ \\
\hline- & turcomanicus Bge. & & & & $\mathrm{Ch} ?$ & $?$ & $\mathrm{E}$ \\
\hline - & Turczaninowii Kar. & Kir & & & . $\mathrm{H}$ ? & $5-6$ & $\mathrm{H}$ \\
\hline - & unifoliatus Bge. & & & & F & $5-6$ & $\mathrm{E}$ \\
\hline - & ustiurtensis Bge. . & . & & . & $\mathrm{H}$ & 5 & $\mathrm{E}$ \\
\hline - & villosissimus Bge. & . & & . & F & 5 & $\mathbf{E}$ \\
\hline - & vulpinus Willd. & & & & $\mathrm{H}$ & $?$ & $\mathrm{R}$ \\
\hline Eremospar & rton aphyllum F.\& M & & . & . & $\mathrm{F}$ & $5-6$ & $\mathrm{H}$ \\
\hline Ewersman & Inia subspinosa (Fisch & & Fedtsch & & $\mathrm{F}$ & 5 & HR \\
\hline Glycyrrhiz & za aspera Pall. & & & & $\mathrm{H}$ & 5 & RV \\
\hline$\ldots$ & glabra L. & & & & $\mathrm{H}$ & $5-6$ & $\mathrm{HRV}^{\star}$ \\
\hline- & uralensis Fisch. & & & & $\mathrm{H}$ & $6 ?$ & $\mathrm{R}$ \\
\hline Goebelia a & alopecuroides L. & & . & & $\mathrm{H}$ ? & 6 & HRV \\
\hline - $\mathrm{p}$ & pachycarpa Schrenk. & & & & Chl? & $5-6$ & $\mathrm{HV}$ \\
\hline Halimoden & dron argenteum (Lan & & D. C. & & $\mathrm{F}$ & $4-5$ & HRV \\
\hline Lotus tent & uifolius Rchb. & & . & . & $\mathrm{H}$ & 5 & $\mathrm{HV}^{\star}$ \\
\hline Oxytropis & riparia Litw. & $\cdot$ & & . & $\mathrm{H}$ ? & 6 & $\mathrm{E}$ \\
\hline Prosopis S & Stephaniana Willd. & . & & & $\mathrm{F}$ & $5-7$ & $\mathrm{~V}^{\star}$ \\
\hline Psoralea $\mathrm{d}$ & Arupacea Bge. & . & . & & . Ch? & $5-8$ & $\mathrm{H}$ \\
\hline Smirnowia & a turkestana Bge. & . & & . & F & 4 & $\mathbf{E}$ \\
\hline Sphaeroph & iysa salsula (Pall.) & . & & & $\mathrm{H}$ & 5 & HR \\
\hline Trigonella & grandiflora Bge. . & . & - & & Th & 5 & $\mathrm{E}$ \\
\hline- & incisa Bth. . & & & & Th & 4 & v \\
\hline- & monantha C. A. M. & & . & & Th & $4-5$ & $\mathrm{~V}^{*}$ \\
\hline & Plantaginaceae. & & & & & & \\
\hline Plantago a & arenaria W. K. & & & & Th & 4 & $\mathrm{HR}^{\star} \mathrm{V}^{\star}$ \\
\hline$-\quad \mathrm{c}$ & Coronopus L. & . & & & $\left.\operatorname{Th}^{1}\right)$ & $5 ?$ & $\mathrm{RV}^{\star}$ \\
\hline - & lachnantha Bge. & . & & & . $\mathrm{Th}$ & 4 & $\mathrm{E}$ \\
\hline
\end{tabular}

1) or biennial (H). 


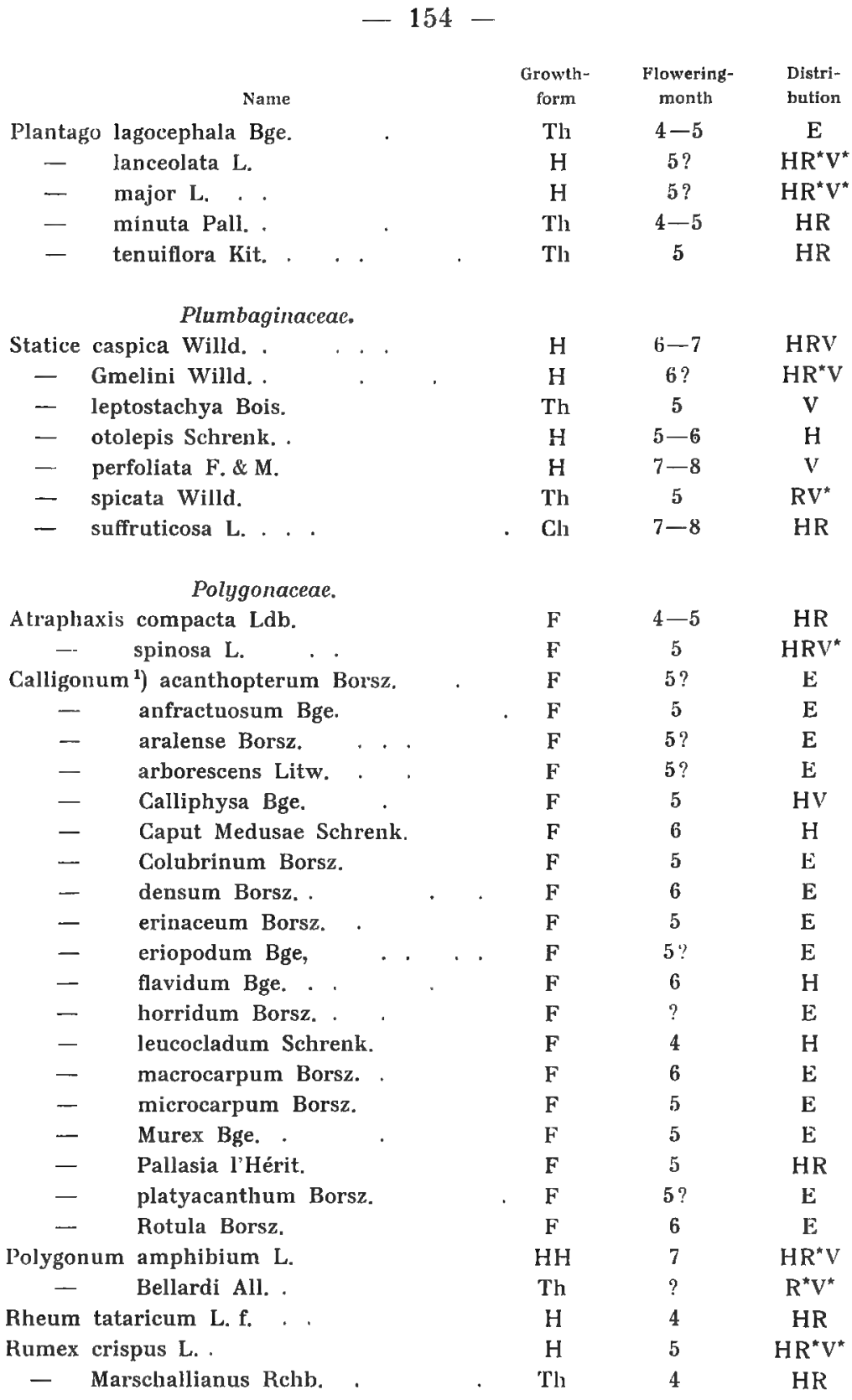

1) This genus, after Bonszczow: Die aralo-kaspischen Calligoneen (Mém. Ac-St. Pb. III 1860). 


$\begin{array}{ccc}\text { Growth- } & \text { Flowering- } & \text { Distri- } \\ \text { form } & \text { month } & \text { bution }\end{array}$

\section{Polamogetonaceae.}

Potamogeton crispus L. . . . . . . $\mathrm{HH}$

$\begin{array}{lc}5 ? & \mathrm{H}^{\star} \mathrm{R}^{\star} \mathrm{V}^{\star} \\ 6 ? & \mathrm{HR} \mathrm{R}^{\star} \mathrm{V}^{\star} \\ 5 ? & \mathrm{R}^{\star} \mathrm{V}^{\star} \\ 5 ? & \mathrm{H}^{\star} \mathrm{R}^{\star} \mathrm{V}^{\star} \\ 5 ? & \mathrm{H}^{\star} \mathrm{R}^{\star} \mathrm{V}^{\star} \\ 6 ? & \mathrm{RV} \\ 6 ? & \mathrm{HRV}\end{array}$

Ruppia maritima L. . . $\mathrm{HH}$

\section{Ranuculaceae.}

Anemone biflora

D. C.

$3-4$

$\mathrm{H}^{*} \mathrm{~V}$

Ceratocephalus

falcatus (L)

-

$3-4$

$V^{*}$

Clematis orientalis L.

$3-4$

$\mathrm{HR}^{*} \mathrm{~V}$

Delphinium camptocarpum F.\& M. . . . Th

$$
7-8
$$

$\mathrm{H}^{*} \mathrm{RV}$

$$
\text { - }
$$

- rugulosum Bois. .. Th

- Zail Ait. \& Hemsl. _ . . $\mathrm{H}$

Eranthis longistipitata Rgl. . . G

Myosurus minimus L. . . . Th

Nigella integrifolia Rgl. . . Th

Ranunculus leptorhynchus Ait. \& Hemsl. . H

$\begin{array}{ll}\text { - } & \text { linearilobus Bge. } \\ \text { - } & \text { Meinshauseni Schrenk. } \\ \text { - } & \\ \text { oxyspermus Willd. } \\ \text { paucistamineus Tausch. (var. } \\ \quad \text { Drouetii (Sch.)) } \\ \text { platyspermus Fisch. } \\ \text { - } \\ \text { sceleratus L. } \\ \text { - Sewerzowi Rgl. }\end{array}$

? $\mathrm{E}$

\section{Rosaceae,}

Hulthemia berberifolia Dumort. . Ch 


$\begin{array}{cccc}\text { Growth- } & \text { Flowering- } & \text { Distri- } \\ \text { Name } & \text { form } & \text { month } & \text { bution }\end{array}$

Rubiaceae.

Asperula Danilewskiana Bas. . . . . Cli?

Callipeltis Cucullaria (L.) Stev. . . . Th

Crucianella filifolia Rgl. \& Winkl. Th

Galium tricorne With . . . . . . . . Th

$\begin{array}{cc}5 & \mathrm{R} \\ 4 & \mathrm{~V}^{*} \\ 4 & \mathrm{E} \\ 5 & \mathrm{~V}^{\star}\end{array}$

Rutaceae.

Haplophyllum lasianthum Bge. . . $\quad \mathrm{H}$

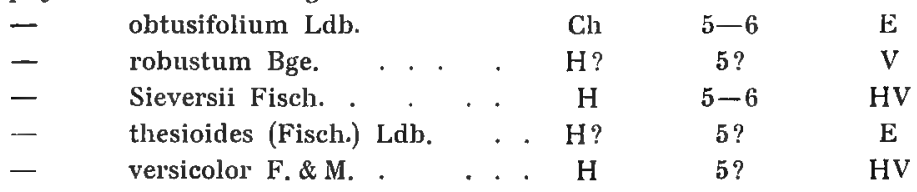

Salicaceae.

Populus euphratica Oliv. . . . . . . F $\quad$ F 4 HRV

-- pruinosa Schrenk . . F F $3-4$ HR

Salix augustifolia L. (var. carmanica Bornm.). F 5 ? HRV

- songorica Anders. . . . . . F F

Salviniaceae.

Salvinia natans (L.) All. . . . . . $\mathrm{HH}$

$R^{*} V$

Scrophulariaceae.

Dodartia orientalis L. . . . . . G

Linaria odora Chav. . . . . . . . . . G

5-6 HRV

$5-6 \quad \mathrm{HR}^{*}$

Scrophularia leucoclada Bge. . . . . . F

5? $\mathrm{E}$

Veronica biloba L. . . . . . . . Th

3-4 $\mathrm{H}^{*} \mathrm{RV}^{*}$

Solanaceae.

Hyoscyamus pusillus L. . . . . Th

Lycium ruthenicum Murr. . . . F

$5 \quad \mathrm{H}^{\star} \mathrm{RV}^{\star}$

- turcomanicum F.\&M. . . . F 6 ? H

Tamaricaceae.

Reaumuria fruticosa Bge. . . . . . $\quad$ F $\quad 7$ ?

- oxiana (Ldb.) Bois. . . F F 7 V

- squarrosa Jaub. Sp. . . . Ch $6-7$ V

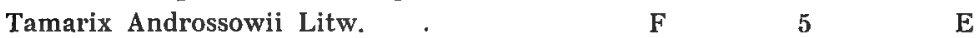

- arceuthoides Bge. . . $\quad$ F $\quad 7$ ?

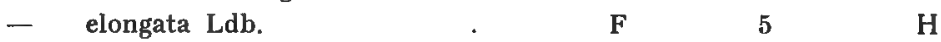

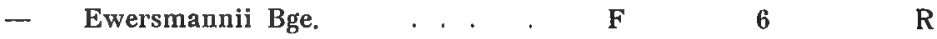

- florida Bge. . $\quad$. $\quad$ F $\quad 50$ V

- hispida Willd. . . . . . . . F $\quad$ F $7-9$ HR

- karakalensis Freyn \& Sint. . . . . . F F 6 E 


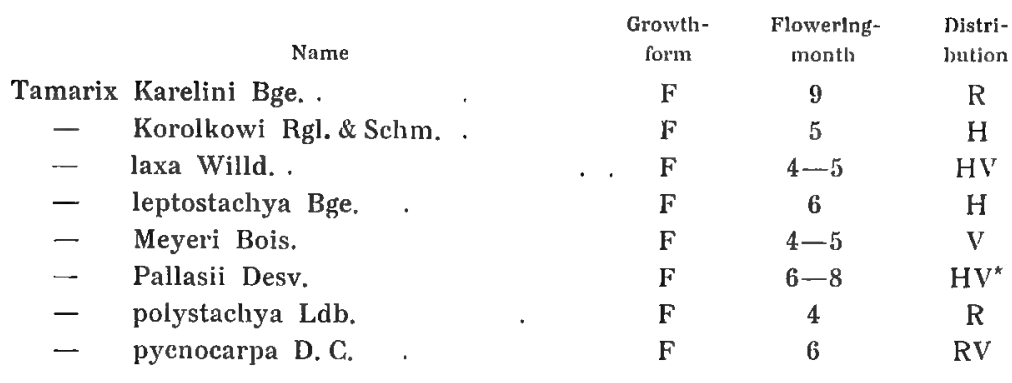

\section{Thymelaeaceae.}

Diarthron vesiculosum (F.\& M.) C. A. M. Th ? HRV

Stellera Lessertii (Wickstr.) C. A. M. . $\quad$ Ch 7 HV

Typhaceae.

Sparganium ramosum Huds. . $\quad$. . HH $\quad \mathbf{5}$ ? $\mathrm{R}^{*} \mathrm{~V}^{*}$

Typha angustifolia L. . . . . $\quad \mathrm{HH} \quad 6 \quad \mathrm{R}^{*} \mathrm{~V}^{*}$

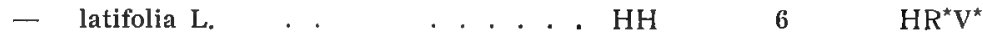

- Laxmanni Lep. . . . . HH 6 HRV

- stenophylla F.\& M. $\quad$. . HH 6 HRV

Umbelliferae.

Aphanopleura capillifolia (Rgl. \& Schm.) Lipsky Th Cachrys didyma Rgl. . . . H

Carum Capusi Frch. . . . . . . . $\mathrm{H}^{1}$ )

- elegans Fzl. $\left.\quad \mathrm{H}^{1}\right)$

- sogdianum Lipsky . H

- trichophyllum Schrenk. . . $\mathrm{H}^{1}$ )

- turkestanicum Lipsky $\mathrm{H}$ ?

Caucalis leptophylla L. . Th

Cryptodiscus ammophilus Bge. . H

- rutaefolius Bge. . . . . $\mathrm{H}$

Cuminum hispanicum Mer. Th

Daucus pulcherrimus Koch $\quad \mathrm{H}^{\mathrm{l}}$ )

Dorema Ammoniacum D. Don. H

Eremodaucus Lehmanni Bge. . Th

Eriosynaphe longifolia D. C. . H?

Ferula Asa foetida L. . . . . $\mathrm{H}$

- diversivittata Rgl.\& Schm. H

- Karelini Bge. . . . $\mathrm{H}$

- nuda Spreng. . . H

- Schair Borsz. . . . . . $\mathrm{H}$

-- Schtschurowskiana Rgl. \& Schm. . H

Galagania fragrantissima Lipsky . . . . . H

$\begin{array}{cc}4-5 & \mathrm{E} \\ 5 & \mathrm{E} \\ 5 & \mathrm{H} \\ 5 & \mathrm{~V}^{*} \\ 4-5 & \mathrm{H} \\ 5 & \mathrm{H} \\ 5 & \mathrm{E} \\ 5 & \mathrm{~V}^{*} \\ 4-5 & \mathrm{E} \\ 4-5 & \mathrm{E} \\ 4 & \mathrm{~V} \\ 5 & \mathrm{RV} \\ 5 & \mathrm{~V} \\ 5 & \mathrm{H} \\ 5 & \mathrm{R} \\ 5 & \mathrm{~V} \\ 5 & \mathrm{H} \\ 5 & \mathrm{H} \\ 5 & \mathrm{HR} \\ 4-5 & \mathrm{E} \\ 5 & \mathrm{E} \\ 5 & \mathrm{H}\end{array}$

1) Perennial or biennial. 


\begin{tabular}{|c|c|c|c|}
\hline Name & $\begin{array}{l}\text { Growth- } \\
\text { form }\end{array}$ & $\begin{array}{l}\text { Flowering- } \\
\text { month }\end{array}$ & $\begin{array}{l}\text { Distri- } \\
\text { bution }\end{array}$ \\
\hline Holopleura carioides Rgl. \& Schm. & $\left.\mathrm{H}^{1}\right)$ & $?$ & $\mathrm{E}$ \\
\hline Hyalolaena jaxartica Bge. & $\mathrm{H}$ & 5 & E \\
\hline Peucedanum rapiferum Trautv. & $\left.\mathrm{H} ?^{1}\right)$ & 5 & $\mathrm{H}$ \\
\hline tenuisectum Rgl \& Schm. & $\mathrm{H}$ & 5 & $\mathrm{H}$ \\
\hline Psammogeton Borszczowii (Rgl.\&Schm.) Lipsky & $\left.\mathrm{H}^{1}\right)$ & 5 & $\mathrm{E}$ \\
\hline setifolium Bois. & Th & 5 & $\mathrm{~V}$ \\
\hline Scaligeria allioides (Rgl. \& Schm.) Bois. & $\left.\mathrm{H}^{1}\right)$ & 5 & $\mathrm{HV}$ \\
\hline - hirtula (Rgl. \& Schm.) Lipsky & $\left.\mathrm{H} ?^{1}\right)$ & $6 ?$ & $\mathrm{H}$ \\
\hline Zozimia absinthifolla D. C. & $H$ & 5 & $\mathrm{RV}^{*}$ \\
\hline \multicolumn{4}{|l|}{ Urticaceae. } \\
\hline Ulmus campestris $\mathrm{Sm}$. & F & 4 & $\mathrm{R}^{*} \mathrm{~V}^{\star}$ \\
\hline \multicolumn{4}{|l|}{ Valerianaceae. } \\
\hline Valerianella Dufresnia Bge. & Th & 5 & $V^{*}$ \\
\hline Szovitsiana F.\& M. & Th & 4 & $\mathrm{HV}^{*}$ \\
\hline orientalis Bois, \& Bal, & Th & 5 & $\mathrm{~V}^{*}$ \\
\hline - $\quad$ turkestanica Rgl. \& Schm. & Thl & 5 & $\mathbf{E}$ \\
\hline - uncinata M. B. & Th & 4 & $\mathrm{RV}$ \\
\hline \multicolumn{4}{|l|}{ Zygophyllaceae. } \\
\hline Biebersteinia multifida D. C. & $\mathrm{H}$ & 5 & $\mathrm{HV}^{*}$ \\
\hline Miltianthus portulaccoides (Cham.) Bge. & $\mathrm{H}$ ? & $4-5$ & $\mathrm{E}$ \\
\hline Nitraria Schoberi L. & $\mathrm{F}$ & $5-6$ & $H^{*} R V$ \\
\hline Peganum Harmala L. & $\mathrm{H}$ & 5 & $\mathrm{HR}^{*} \mathrm{~V}^{*}$ \\
\hline Tetradiclis tenella (Ehrb.) Litw. & Th & 4 & $\mathrm{HRV}^{*}$ \\
\hline Tribulus terrestris $\mathrm{L}$. & Th & 5 & $\mathrm{HRV}^{\star}$ \\
\hline Zygophyllum brachypterum Kar. Kir. & $\mathrm{H}$ ? & $6 ?$ & HV \\
\hline - $\quad$ Eichwaldii C. A. M. & $\mathrm{H}$ & $4-5$ & $\mathrm{E}$ \\
\hline eurypterum Bols. \& Bulse & $\mathrm{F}$ & $?$ & $\mathrm{~V}^{*}$ \\
\hline Fabago L. & $\mathrm{H}$ & 5 & $\mathrm{H}^{\star} \mathrm{R}^{\star} \mathrm{V}^{*}$ \\
\hline Karelini F. \& M. & Th & 5 & $\mathbf{E}$ \\
\hline macrophyllum Rgl. \& Schm. & $\mathrm{H}$ & $?$ & $\mathbf{E}$ \\
\hline macropterum C. A. M. & $\mathrm{H}$ & 5 & $\mathrm{HV}$ \\
\hline miniatum Ch. \& Schl. & $\mathrm{H}$ & 5 & $\mathrm{H}$ \\
\hline ovigerum Fisch. & $\mathrm{H}$ & 5 & $\mathrm{E}$ \\
\hline turcomanicum F. \& M. & $\mathrm{H}$ & $?$ & $\mathbf{E}$ \\
\hline
\end{tabular}

1) Perennial or biennial.

A summary of the species and growth-forms in the above list gives the result that out of 768 species 87 are Fanerophytes, 52 Chamaephytes, 210 Hemicryptophytes, 70 Geophytes, 38 Hydro- and Helophytes, and 310 Therophytes. There is also one species of Cuscuta. These numbers calculated as 
percentages give the top line in table 3 , so that this is the "biological spectrum" of the territory. It shows, that the

Table 3.

\begin{tabular}{|c|c|c|c|c|c|c|c|}
\hline & \multirow{2}{*}{$\begin{array}{c}\text { Number } \\
\text { of } \\
\text { species }\end{array}$} & \multicolumn{6}{|c|}{ Percentage of species under each growth-form } \\
\hline & & F & Ch & H & $\mathrm{G}$ & $\mathrm{HH}$ & Th \\
\hline Transcaspian Lowlands & 768 & 11 & 7 & 27 & 9 & 5 & 41 \\
\hline $\begin{array}{l}\text { Government of Yekate- } \\
\text { rinoslaw } \ldots \ldots \ldots \ldots\end{array}$ & 1046 & 5 & 3 & $5 \mathbf{5}$ & 8 & 5 & 24 \\
\hline Pamir ............. & 514 & 1 & 12 & 63 & 5 & 5 & 14 \\
\hline Death Valley. & 294 & $\left.26^{1}\right)$ & 7 & 18 & 2 & 5 & 42 \\
\hline Samos ......... & 400 & 9 & 13 & 32 & 11 & 2 & 33 \\
\hline Libyan desert & 194 & 12 & 21 & 20 & 4 & 1 & 42 \\
\hline Cyrenaica & 375 & 9 & 14 & 19 & 8 & . & 50 \\
\hline Normal spectrum... & 400 & $\left.47^{2}\right)$ & 9 & 27 & 3 & 1 & 13 \\
\hline
\end{tabular}

1) Inclusive of $3 \%$ stem-succulents.

2) Inclusive of $1 \%$ stem-succulents and $3 \%$ epiphytes,

Therophytes are the most abundant growth-form, then follow the Hemicryptophytes and the Fanerophytes. The other series of numbers ("spectra") are inserted for comparison. The first two series are prepared from my own calculations: Yekaterinoslaw according to BÉkétof's Flora, and Pamir from O. Fedtschenko's "Flore du Pamir" with supplements, and additions of my own. The others, namely Death Valley (in western North-America), Samos, the Libyan desert and Cyrenaica (Barka), and the "Normal Spectrum" I have quoted from Raunkier (1908 p. 55). The "Normal Spectrum" is the biological spectrum for 400 species taken at random from a list of the plants of the whole earth, it should accordingly be the spectrum of the whole earth. If we now compare it with the spectrum of Transcaspia it will be seen that the latter has proportionately a much larger number of Therophytes and a much smaller number of Fanerophytes than the earth as a whole, the other deviations being less important. Transcaspia thus lies outside the region of Fanerophytes, the region with a fanerophytic climate i. e. a tropical climate with abundant precipitation. 
On the other hand the spectrum of Transcaspia agrees in the main with the spectra for Samos, the Libyan desert, Cyrenaica and Death Valley respectively. The point of maximum intensity for all these spectra lies in the Therophytes. In the hotter of these areas, the Libyan desert and Death Valley, the Chamaephytes and the Fanerophytes are also prominent.

As regards its biological spectrum, Transcaspia thus presents the same type as the countries of the Mediterranean, at least the eastern parts. We are further led to the conclusion that parts at least of the western countries of the Mediterranean should also be included here because 35 per ct. Therophytes are found on the Iberian steppes (WiLlкomm 1894 p. 280).

All these Therophyte-spectra are contingent upon the same climate: winter-rains and a dry hot summer. This forms a link in what is termed by Raunisier a C-climate series, i. e. a series starting at the Equator with a tropical moist climate, its continuation northwards being determined in this way, that although the heat decreases so does the precipitation at least as regards the summer. Thus we get a dry climate characterised by a "Therophyte spectrum". Still farther north the precipitation again increases, and we have here a temperate Hemicryptophyte-climate which in arctic countries is succeeded by a Chamaephyte-climate. Such C-climate series are especially met with in the western parts of large continents. Death Valley shows the unfavourable dry climate in the series which runs through western America. Transcaspia and the countries of the Mediterranean represent the corresponding link in the series through the western parts of the continents of the Old World.

The B-Climate series passing through the eastern parts of the continents, and which has a favourable precipitation throughout does not come within the scope of this memoir.

If on the other hand we compare the spectrum of Transcaspia with those of Yekaterinoslaw and Pamir, we arrive at the result that whether we proceed from Transcaspia northwards to the south Russian steppe, or upwards into the mountains, the Therophytes decrease, while the Hemicryptophytes increase in number. This is in accordance 
with Raunkier's statement that the Therophytes are the growth-form best adapted to a dry hot climate, but that they decrease in numbers where the temperature is low.

As already stated the most important characteristic of the biological spectrum of the Transcaspian lowlands is the great number of Therophytes or annual plants (41 per ct.). This is also characteristic of countries to the south and south-west, and in the desert areas of western North-America. (see table 3 p. 159). According to MAC Dougal (1909) and Cannon (1909), the Sonora desert has two precipitation-maxima with spells of dry weather between (comp. p. 59); during the two wet periods there is a great abundance of mesophytic annual plants (ephemerals), the species of the two periods being different although some of them appear twice a year both in summer and winter. (See also Thornber l. c.)

Most of the annual plants of Transcaspia belong to what Volkens (l. c. p. 20) terms ephemerals, that is plants which complete their life-history from germination to the ripening of seeds during the short and comparatively moist spring-time (see above p. 59). In countries where the winter is warm, germination sometimes takes place during autumn or winter (Volkens p. 19), but in the cold winter of Transcaspia this is not likely to be the case.

The existence of the ephemeral plants is dependent on a short comparatively moist favourable period, sufficiently warm and long enough to permit them to complete their development. The adaptations of the plants consist in the capacity for rapid development and in the resistance of the seeds to prolonged dessication; their vegetative parts on the other hand show only slight adaptation against dessication, so that they must be termed mesophytic in structure.

An important condition for the welfare of the ephemeral plants, which also holds good as regards the longer lived annual plants, is that sufficient open ground is available and that the perennials or the ligneous species do not grow so close as to hamper the germination and growth of those plants which must start afresh from seeds every year. This condition is fulfilled in the Transcaspian lowlands where a dense vegetation is only found in the valleys of the rivers and 
under the most favourable conditions. Thus conditions which bring about a scattered growth of perennial plants favour the annual ones (See for instance M. VAHL 1904 p. 67).

The summer-annuals, fairly numerous in the Transcaspian lowlands, are adapted in a different way and to different conditions. The plant lives through the summer, hence it must endure desiccation and is xerophytic in structure. They do not die till winter sets in.

Table 4.

\begin{tabular}{|c|c|c|c|}
\hline & \multirow[b]{2}{*}{$\begin{array}{c}\text { Number } \\
\text { of } \\
\text { Annunls }\end{array}$} & \multicolumn{2}{|c|}{ Percentage of annuals } \\
\hline & & $\begin{array}{c}\text { already } \\
\text { flowered } \\
\text { by 1. July }\end{array}$ & $\begin{array}{c}\text { flowering } \\
\text { wholly or } \\
\text { partially } \\
\text { after } 1 \text {. July }\end{array}$ \\
\hline Denmark & 210 & 20 & 80 \\
\hline Yekaterinoslaw ... & 240 & 45 & 55 \\
\hline 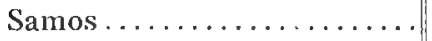 & 117 & 62 & 38 \\
\hline Spain (Halophytes) & 122 & 65 & 35 \\
\hline Transcaspian Lowlands..... & 310 & 79 & 21 \\
\hline
\end{tabular}

The last line in Table 4 gives the percentages of early and late flowering annual plants in the Transcapian lowlands. As some ephemeral plants may be seen in flower at the beginning of June, I have fixed the limit at July 1. Plants which may be found flowering on the first of July and later are thus considered late-flowering, those which have completed flowering before the end of June are termed early flowering. When the flowering season of any species is unknown to me, it is generally given as early flowering. This table is intended to give some notion as to the proportion between ephemerals and summer-annuals. Even though these definitions do not perfectly differentiate between early and late flowering, yet they do so to a certain extent. An attempt was made to draw up a list of summer-annual plants, regardless of the flowering season. but owing to insufficient knowledge of the life-history of certain species, I shall not give it here. It is noteworthy however, that 74 per ct. of the (86) species flower after July 1 . The division according to flowering season thus makes the number of late-flowering 
species somewhat smaller than the number of summer-annuals. In the case of several of the other countries given in the table, there was the same difficulty in obtaining reliable comparative data as to the life-period of the plants, therefore I am obliged to limit the table to a comparative statement of the flowering season for all the countries. This table will to some extent illustrate the proportion between ephemerals and summer-annual plants.

The four upper lines are given for comparative purposes. The figures for Denmark are calculated from Raunkiar's Excursion-Flora, for Yekaterinoslaw according to BÉKÉTOFF, for Samos according to Stefani, Fonsyth Major \& Barbey, and Halacsy, and the figures for Spain according to Willkomm $\left.(1852)^{1}\right)$. No figures are given for the Libyan desert, as the flowering season is not recorded in Ascherson and SchwernFURTh's flora, also because many of the annual plants are facultative biennials or perennials, and some flower both in spring and winter. The following species of annual summerplants comparable to those occurring in the Transcaspian desert - i. e. not facultative perennials - are given by Volkens for the Libyan desert: Moricandia clavata, Diplotaxis Harra, Monsonia nivea, Mesembryanthemum crystallinum, $M$. nodiflorum, M. Forskalei, Aizoon canariense. Although this list be not complete, it indicates that there are very few summer-annual plants in the Libyan desert, so that probably this locality should have been placed at the foot of the table, being the one with the greatest number of ephemeral plants.

The desert of western North America might be placed in the table beside Transcaspia. According to Thornber there are in the desert of Tucson about 20 per ct. "longlived annuals" and 80 per ct. short-lived ones. By counting up Spalding's list (1909) of the plants of the Tucson country I obtained respectively 21 and 79 per ct. of these two categories. The proportion thus agrees approximately with that found in Transcaspia.

1) See also Willкomm 1896 p. 150. This work cannot be employed for statistics, as all the species of the formations are not recorded. 
The figures in table 4 show that while in Denmark four-fifths of the annuals flower after the first of July, we have in the South-Russian steppe (Yekaterinoslaw) about one half, in Greece and Spain about one third, and in the Transcaspian lowlands about one fifth which are late-flowering.

In the series: Libyan desert, Transcaspian desert, Spain, South-Russian Steppe, Denmark, the number of summerannual plants thus steadily increases. And throughout the same series the summer becomes less warm and less dry. In Cairo there is no rain during 4-6 summer months and the mean temperature of July is $29^{\circ} \mathrm{C}$.; in Merw 3-4 summer months are rainless, and the mean July temperature is $30,2^{\circ} \mathrm{C}$., (Askhabad 29,7 $7^{\circ} \mathrm{C}$., Petro Alexandrowsk $28, \pi^{0}$ C.; Table 1 p. 17). In Spain no month is perfectly rainless though July and August are very dry, and the mean July temperature is, for instance, Murcia $29^{\circ} \mathrm{C}$., Madrid $24,5^{\circ} \mathrm{C}$. Yekaterinoslaw has as mean July temperature of $23,0^{\circ}$ C. and the precipitation is greatest in July and smallest during winter. ${ }^{1}$ )

This leads us to the conclusion that the number of summer-annual plants is more especially dependent on the summer rainfall, as might be expected. From north towards the south the conditions of life during summer become more and more unfavourable, so that fewer and fewer annual species are able to endure, namely only those adapted to withstand increasingly unfavourable conditions.

But the winter temperatures may also play a part in determining the relative number of annual summer-plants, since plants have a better chance of hibernating in countries with warmer winters than where the cold is severe. In this way annual summer-plants might become perennials. The statement by Volkens (l. c. p. 21), that facultative annual and perennial plants are characteristic for the Libyan desert, is perhaps not only correlated with the summer but also with the winter conditions.

The mean temperature at Cairo for Jan. is $11,9^{\circ} \mathrm{C}$., and even if (according to HANN) a few degrees of frost are some-

1) The temperature records are cited from HANN 1897, III. 
times recorded, this is notbing compared with Merw which has a mean temperature for January of $-0,6^{\circ} \mathrm{C}$. (Askhabad - 0,2 ${ }^{\circ}$ C., Petro Alexandrowsk $-5,5^{\circ}$, table 1) and Yekaterinoslaw which has $-74^{0}$ C., the minimum temperatures of both localities being nearly $-20^{\circ} \mathrm{C}$. or even less.

Spain, which as regards July-temperature takes third place, becomes second in this respect since the winter there is much warmer than in Transcaspia (Murcia 9, ${ }^{\circ}$ C., Zaragoza $5,2^{0} \mathrm{C}$., Madrid $4,9^{\circ} \mathrm{C}$. in January). The number of annual summer-plants in this case is thus in accordance with the July temperature, not that of January. This leads us to the conclusion that the January temperature may be a major factor only when it is high, while marked differences in the lower temperatures do not seem to be of any importance. The data are, however, too scanty to allow us to come to any decisive conclusion.

\section{Table 5 .}

Distribution of the growth-forms of Transcaspian species amongst certain natural orders.

\begin{tabular}{|c|c|c|c|c|c|c|c|}
\hline & \multirow{2}{*}{$\begin{array}{c}\text { Number } \\
\text { of } \\
\text { species }\end{array}$} & \multicolumn{6}{|c|}{ Percentage of species occurring as growth-forms } \\
\hline & & $\mathrm{F}$ & $\mathrm{Ch}$. & $\mathrm{H}$ & G & $\mathrm{HH}$ & Th. \\
\hline Borraginaceae ...... & 42 & . . & 4 & 29 & 10 & . & 57 \\
\hline Caryophyllaceae .... & 25 & . & 36 & 20 & $\ldots$ & .. & 44 \\
\hline Chenopodiaceae .... & 94 & 13 & 11 & 4 & $\ldots$ & . & 72 \\
\hline Compositae......... & 103 & 2 & 8 & 45 & 3 & . & 42 \\
\hline Cruciferae......... & 51 & . & . & 10 & & . & 90 \\
\hline Gramineae......... & 44 & .. & . & 25 & 18 & .. & 57 \\
\hline Labiatae........ . . & 20 & .. & 5 & $\mathbf{5 5}$ & $\ldots$ & 10 & 30 \\
\hline Liliaceae . . . . . . . & 24 & $\therefore$ & . & .. & 100 & . & . \\
\hline Papilionaceae. . ..... & 85 & 27 & 10 & 42 & $\cdots$ & . & 21 \\
\hline Polygonaceae .. & 26 & 80 & . & 8 & . & 4 & 8 \\
\hline Ranunculaceae ..... & 23 & . & 4 & 48 & 4 & 4 & 40 \\
\hline Umbelliferae........ & 31 & . & . & 84 & $\ldots$ & . & 16 \\
\hline Tamaricaceae........ & 18 & 95 & 5 & . & . & . & $\cdots$ \\
\hline Zygophyllaceae.... . . & 17 & 12 & $\ldots$ & 69 & $\ldots$ & $\ldots$ & 19 \\
\hline
\end{tabular}

From table 5 it will be seen which natural orders are specially represented by annual species in the Transcaspian 
desert; as the distribution of the growth-forms of the species of larger families are here given as percentages. The orders which are especially represented by annual species are the Cruciferae and the Chenopodiaceae, the percentage of these being respectively 90 and 72 . Of these the Cruciferae are all early flowering ephemerals, whereas about 82 per ct. of the annual Chenopodiaceae are summer-plants which flower after the beginning of July. A large proportion of the early flowering annual Chenopodiaceae also live far into the summer.

These two families, the Cruciferae and the Chenopodiaceae are thus typical representatives of two widely different series of adaptations to desert-life: the one shows itself in the quick development of plants of mesophylic structure during the favourable season; the other is characterised by slow development combined with the power to withstand the unfavourable conditions of the dry season. The former series include all the other families in table 5 with a large number of annual plants, e. g. Borraginaceae, Gramineae and Ranunculaceae. Outside the Chenopodiaceae there are very few annual summer-plants.

That the adaptation of the ephemeral planfs is advantageous is easily seen; the continuity of the race is ensured with a slight expenditure of material. Life with these plants seems a much simpler matter than in the case of the annual summer-plants which have to contend with a long hot summer before their seeds are ripened. The existence of the latter is far more expensive, because for one thing material must be produced for the development of mechanical, waterstoring, and other specialised tissues which the ephemerals do not require; moreover many of the annual summer-plants do not complete their natural span of life because they are buried by the sand, or the soil blows away, or they die of thirst.

In this connection attention is drawn to the outstanding difference between the mode of occurrence of the ephemerals and the annual summer-plants. As already described, the former often appear in masses during spring, while the latter almost always occur as single plants standing widely apart. This is of course largely due to the greater number of 
species of the ephemerals, but my opinion is that the number of individuals of most of the ephemeral species is much larger than that of the summer-annuals. This question ought to be more closely investigated.

Even though the adaptations of the summer-annual plants must be regarded as favourable, otherwise the plants would not be able to exist, they seem to be much less favourable than the adaptations of the ephemerals or those of the perennials. The latter remain alive year after year, capable of storing nutriment and of developing a strong root-system, while as regards propagation by seeds they have the same chance as the annual plants.

The annualness of the annual summer-plants inherent in their nature thus seems to be an unfavourable point in their adaptation to the conditions of the Transcaspian desert. That so few species of them occur there is perhaps a result of this.

Next to the Therophytes the Hemicryptophytes are the most abundant type in the Transcaspian desert. Their percentage (27) ranges between the figures from the NorthAfrican and North-American desert $(19,20,18)$ and Samos (32) as shown in Table 3. They are far less numerous here than in the South-Russian steppe (Yekaterinoslaw) and Pamir.

Most of them flower early, about the month of May. After calculation, I find that only about 10 per ct. of the Hemicryptophytes flower after July 1, so that about 90 per ct. are early flowering. These figures are only approximate, as details on the flowering season of many species are lacking.

Actual numbers have less interest here than in the case of annual plants, because the latter usually die after they have produced flower and fruit, whereas perennial plants in many cases continue to be vegetative after that time. Statistics of the flowering season therefore give no information about the vegetative period of perennials.

Most Hemicryptophytes flower early and have completed flowering before the end of June. As previously stated (p. 59) many of them wither when the seeds are ripe. This is probably the case with the majority, some of them have 
already been referred to. They have also ephemeral shoots, mesophytic in structure and arising from perennial hypogeal parts. In other Hemicryptophytes the epigeal shoots live through the whole summer, e. g. in species of Zygophyllum, Anabasis, Statice, probably also in a few Cousinia and Astragalus; their shoots are xerophytic in structure and have this biological character in common with the annual summerplants that the shoots die when winter sets in.

No information is available on the few plants recorded as biennials, for instance Tragopogon. It is unlikely that the species of Tragopogon carry fresh leaves throughout the whole summer.

The Chenopodiaceae as a group are strikingly deficient in hemicryptophytes, they have only 4 per ct. The Tamaricaceae and the Liliaceae have none at all. The paucity of hemicryptophytes in the Chenopodiaceae, so many of which seem specially adapted to desert-life, may perhaps be explained in this way, that this type is not well adapted to the natural conditions prevailing during summer in the desert. Yet the correctness of this supposition may be questioned when we consider the Zygophyllaceae, likewise true summerplants and with 11 hemicryptophyte-species ( 69 per ct.).

Of the remaining orders the Umbelliferae in particular include a large number of hemicryptophytes all or most of which are spring-plants. (See table 5).

Next in order to the Hemicryptophytes (Table 3) follow the Fanerophytes, the trees and shrubs. These all belong to Raunkiser's Micro- and Nanofanerophytes.

In the Transcaspian desert there are 11 per ct. Fanerophytes, about the same proportion as in the North-African deserts (Libyan desert 12, Cyrenaica 9) and in Samos (9), but much less than in Death Valley with 23 p. ct. On the other hand, the South Russian Steppe shows only 5 per ct. and the Spanish Steppe about the same number ${ }^{1}$. Denmark has 7, Stuttgarl 9 per ct. (Raunkiær).

Only 14 out of 87 Fanerophytes in the list may still be found flowering after July $1^{\text {st }}$ and of these 8 are Cheno-

1) Willigomi 1895 p. 280. 
podiaceae. What was said of the Hemicryptophytes is still more the case here: that the early flowering species may be summer-plants; here every one is such, and not one is known to rest during the summer-periods, although some of the species of Astragalus may shed their leaflets.

The Transcaspian Fanerophytes occur in greatest numbers and attain their highest development in the Sand-desert. As already stated (p. 79), the Sand-desert has a rain-absorbing soil, but its capillary action is slight, hence there must be larger supply of water in the deeper layers than in the Claydeserts. This is naturally correlated with the occurrence of trees since these have long roots capable of extending down to the water; compare also p. 48.

Another factor of importance for the ground-water and therefore for the Fanerophytes, is the density of the vegetation. Wherever in dry regions there is a rich vegetation of herbs or small shrubs, these will intercept and absorb the water, so that it is not allowed to sink into the soil. KoSTYTSCHEFF points out that forests might grow on the SouthRussian steppe if the surface were loosened, so that water might penetrate the soil. Why this does not take place is, he states, because the surface of loess is impervious to water, especially when covered by plants.

Without entering into the question why the Russian steppe is treeless, it is noteworthy that Transcaspia presents better conditions for growth of trees than South-Russia; this is a result of the absorptive capacity of the soil due to its structure and to the open plant-covering, aided also by climatic conditions. Reference may be made in this connection to Schimper's statement (p. 527) that the South-Russian steppe has a dry as well as a cold winter, an element hostile to the growth of trees. For when dry winds blow at the same time as the ground is frozen, the trees with their branches and buds more exposed than smaller plants, will be unable to compensate for loss by transpiration.

Somewhat similar conditions prevail on the Spanish steppes; the winter is cold, dry and windy ${ }^{1}$ ). May has the greatest amount of precipitation.

1) Climatic tables for Zaragoza and Valladolid in Meteorol. Zeitschrift 9. 1874. p. 218. 
In Transcaspia the conditions are just the reverse. As may be seen from table 1 (p. 17), the precipitation is greatest in winter so that the coldest season is comparatively humid. In this respect the climate to a certain degree favours the growth of trees. But as a whole it is only to a slight degree favourable! The long dry period which occurs during the vegetative period for trees necessitates the utmost economy as regards water. Therefore only the more xerophytic trees are able to live; their external and internal structure will be described below (chap. 13).

Fanerophytes occur in comparatively few of the natural orders represented in Transcaspia (Table 5). For instance in Borraginaceae, Caryophyllaceae, Cruciferae, Labiatae, Ranunculaceae and Umbelliferae they are totally absent. On the other hand, the numerous species of Tamarix and Calligonum have this effect that the Tamaricaceae and Polygonaceae consist mainly of trees and bushes. The species of Calligonum are more especially true desert-plants. Many of the fanerophytic Papilionaceae (Astragalus, Ammodendron, Eremosparton) and Chenopodiaceae (Salsola, Haloxylon), are likewise true desert plants, xerophytic in structure. On the contrary the only two fanerophytic Compositae (Artemisia procera and Zollikoferia acanthodes) are unimportant species, rarely recorded.

The 10 per ct. of Geophytes in the Transcaspian desert is a rather high figure compared with the "Normal-Spectrum", but it is in agreement with Samos and Cyrenaica (Table 3). Of the 72 geophytes, 33 (46 per et.) are rhizomeplants, 24 (33 per ct.) are bulbous plants, 9 tuberous plants (13 per ct.), and 6 parasites (8 per ct., Orobancheaceae).

As far as known only 5 geophytes may be found flowering after July 1. Only one of these Eremurus Olgae is a bulbous plant. The others (Tournefortia sibirica, Pluchea caspica, Cressa cretica, Saccharum spontaneum) have rhizomes. The term early flowering when applied to the rhizome-geophytes does not indicate that the epigeal shoots die after that time, for they continue to vegetate e. g. in Heliotropium Radula and chorassanicum, Acroptilon, Dodartia, Aristida and Elymus. Bulbous and tuberous plants, on the contrary, almost all 
finish the aerial period of their life before the end of June and thus belong to the mesophytic aspect of the vegetation, whereas many Rhizome-geophytes are very xerophytic e. g. Heliotropium, Cressa, Aristida, Elymus, Dodartia. The Irises and some others are mesophytic.

The natural order Liliaceae consists entirely of geophytes. (Table 5). The grasses include some very important and characteristic desert-forms of geophytes: Aristida, Elymus, Aeluropus and several species on the river-banks e. g. Phragmites, Saccharum, Calamagrostis pseudophragmites. The Borraginaceae include important species of Heliotropium. Most of the orders have no geophytes at all. (Table 5).

There are few Chamaephytes in the Transcaspian desert. Assuming that the classification of growth-forms is correct, 52 species belong to this type, all undershrubs with the exception of Nanophytum erinaceum, which is rather a cushion-plant. The aerial shoots of such chamaephytes die back until near the surface of the soil, and the buds for rejuvenation are situated at the base of the lignified and persistent stems. This is also the case with Capparis spinosa and Hulthemia berberifolia, but the shoots of these lie prostrate on the ground as in the more typical chamaephytes.

The species given in the list as Chamaephytes are generally desert-plants, with green shoots which live through the whole summer and contribute to the xerophytic aspect. More than half of them - at least 29 - flower after July 1. Some species play a rather prominent part in the desert, thus Anabasis salsa, Arthrophytum, Noaea spinosissima, Artemisia, Convolvulus erinaceus and fruticosus, Alhagi, Psoralea drupacea, Hulthemia berberifolia, Haplophyllum obtusifolium, Reaumuria squarrosa and Stellera Lessertii. These chamaephytes seem to have attained a high degree of adaptation to desert-life. The generally follow the clay-soil although some of them appear on the less fugitive sandy soils (Convolvulus erinaceus).

Although there are relatively few Chamaephytes in the Transcaspian desert (7 per ct.), they are far more numerous there than in temperate countries. Denmark for instance has only 3 per ct. But if we go southwards from Transcaspia 
we find in certain tropical or semi-tropical deserts a far greater percentage, thus in the Libyan desert 21 and at Aden 27 per ct. (Raunkter). This would seem to suggest that the cold winter of the Transcaspian desert is unfavourable to the chamaephytes.

It is known that aridity and heat favour lignification (WARMING 1909 p. 127), and this may sufficiently explain the occurrence of the chamaephytes - at any rate the undershrubs - in dry desert areas. That the Chamaephyte form is in itself a favourable adaptation for the plants is not directly obvious. Lignification and mechanical strength must be favourable (WARming l. c.), and perhaps it may have this effect that the assimilating shoots are removed from the surface of the soil.

The Caryophyllaceae, Chenopodiaceae and Papilionaceae include proportionately the greater number of chamaephytes, while most of the other orders in Table 5 have few or none.

As to the 39 species of Aquatics and Marsh-plants I can add nothing of special interest for Transcaspia. Besides a number of Cyperaceae and Potamogetonaceae, the list includes plants like Valisneria spiralis, Lycopus europaeus, Lemna, Najas, Epilobium hirsutum, Polygonum amphibium, Salvinia, Typha. So far as the biological type is concerned, there is nothing about these plants to characterise them as especially Transcaspian. Something might be found by a closer study of their finer adaptations, such as anatomical structure, flowering, etc., an investigation I have not attempted.

The Aquatics and Marsh-plants are so far as known early flowering, only 5 species flowering entirely or partially after July 1.

Summarising what has been said about the growthforms and their vegetative season, we may divide the growthforms into those characteristic for the xerophytic aspect (the summer aspect), allowing at the same time that they may live and vegetate in spring; and those which vegetate only in spring and belong to the mesophytic aspect.

The Xerophytic Aspect includes: 
All the Fanerophytes;

All the Chamaephytes;

A few Hemicryptophytes;

Some Rhizome-Geophytes (but only a few);

A few Therophytes.

The Mesophytic Aspect includes:

Many Hemicryptophytes;

Most of the bulbous Geophytes and some Rhizome-

Many 'Therophytes.

Geophytes;

The percentages of early and late-flowering species already given show that by far the greater proportion of the plants of Transcaspia are early flowering. The number of lateflowering species in the list of plants is 123 , which is 16 per ct. of all the species. The species whose flowering season is not stated, are as a rule taken as early flowering.

It holds good for most growth-forms that the majority of the species flower early. This also applies to the Therophytes, but for one group of these the summer-annuals, the opposite is the case; the same is seen in the Chamaephytes.

\section{CHAPTER 13}

\section{Descriptions of the Growth-Forms.}

In this chapter an attempt is made to give a description of some of the structural features of Transcaspian desertplants. Even a brief description of each of the desert-plants of our area would fill a, large volume, hence the following is limited to species known from personal observation and collected by myself supplemented in some cases by other material. In this respect the "Herbarium florae Rossicae" has been of great service.

The plant-species are arranged according to their "biolo- 
gical types" in the sense adopted by Raunkier, a method of arrangement which offers the best opportunities for comparison between morphological and biological characteristics, especially those of shoot-structure and branching in relation to the nature of the leaves. Amongst the various types I have given most attention to those contributing to the summeraspect, i. e. the true Xerophytes, more especially the Fanerophytes and Chamaephytes. This course was adopted because I had more material of these plants at my disposal, and partly because of the special interest attached to the structure of plants with persistent epigeal shoots.

In what follows, the occurrence, foliage and ramification of each species are described, flowering and fructification being also referred to. Some of the descriptions are accompanied by photographs of herbarium specimens, or by sketches some of which are taken from material preserved in alcohol. So far as material permitted, the anatomy of the assimilating organs has been examined. Axial organs which are not assimilatory I have not examined, first because the material was too limited for such an investigation so that any comparative conclusions would be rather doubtful, secondly in order to limit the work, and finally because thorough descriptions of the anatomy of the axial organs of a number of species are given in B. Jönsson's valuable memoir.

\section{A. Fanerophytes.}

The trees and shrubs have been included as far as possible. The descriptions begin with the "dry" plants and proceed towards the more succulent.

Eremosparton aphyllum F. \& M.

A leafless shrub or small tree, generally about $1-2$ metres high, rarely exceeding 4 metres. It is at home in the sand-desert where it is one of the most characteristic plants. The roots are long and some are horizontal. According to PAlezki, the roots are capable of producing aerial shoots and although this species might for this reason be cultivated 
in the plantations, this is not done, because the seeds are destroyed by insects and it does not grow well from cultings. Eremosparton has slender, pliant branches (fig. 23). The bark is yellow in older specimens, green in younger ones.

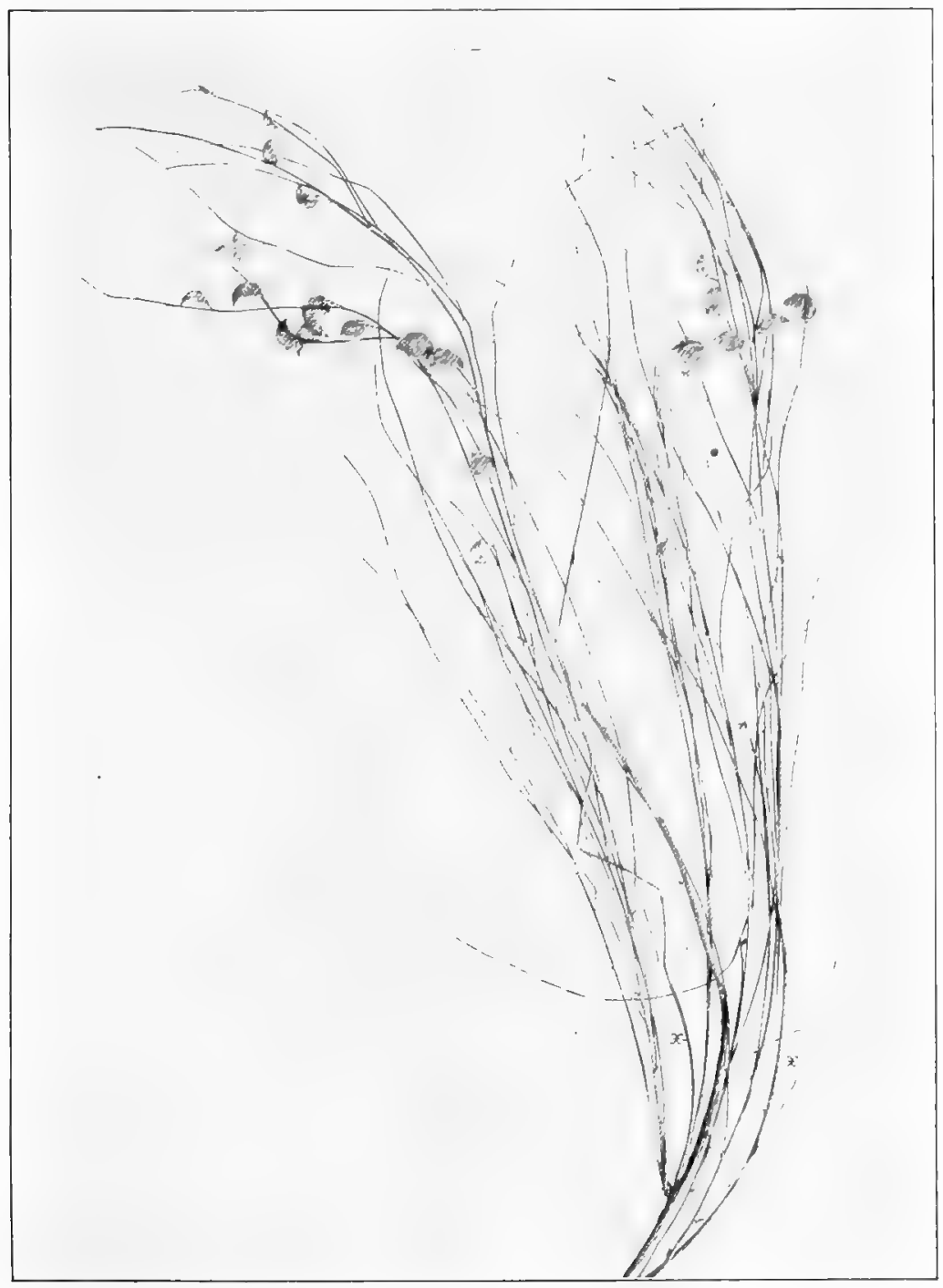

Fig. 23. Eremosparton aphyllum with fruits. The middle thicker branch is the year-shoot of the previous year, loroken at the point. $X, X$ : last year's assimilation-branches, now dead, Beyond these new branches have arisen. $J$ ne. 
The year-shoots have small, scattered, scaly leaves, mere rudiments which can play no part in assimilation. In their axils lateral shoots occur which are smaller than the main shoot and bear scale-leaves. The year-shoots are therefore branched. The lateral shoots (year-shoot branches) bear flowers

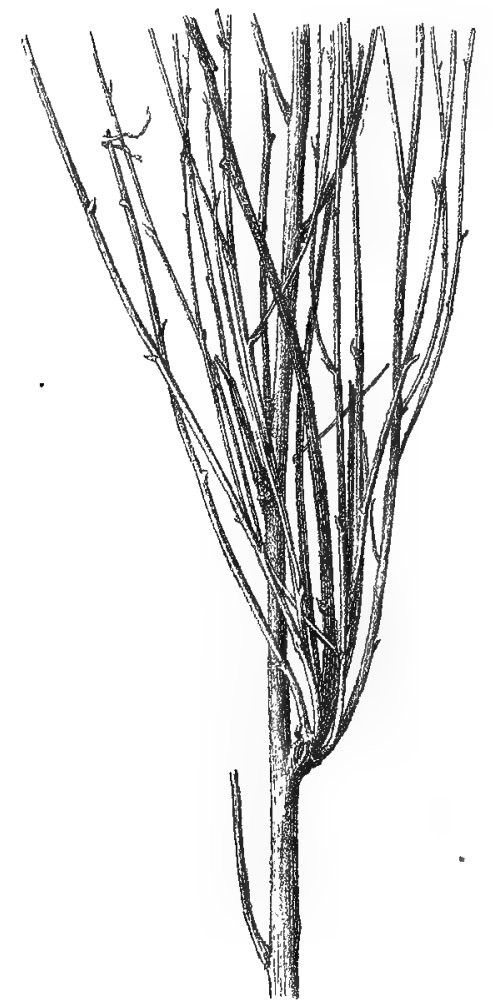

Fig. 24. A year-old branch of Eremosparton aphyllum. A bunch of new assimilation-shoots arising from an old leaf-axil at the base of three dead (strongly shaded) assimilation-shoots. in the upper leaf-axils.

Before the beginning of the next vegetative period, the ultimate parts of the yearshoot and all its smaller branches die, and only the primary axis (the main shoot in fig. 24) remains, after losing its green bark and assuming the yellow, smooth, hard bark instead. The branches of the year-shoot thus live only through one vegetative period, they are biologically equivalent to leaves and may be termed assimilation-branches. (Rindowsky, see below p. 178).

The next year-shoot arises from the nodes of the primary year-shoot where the assimilation-branches formerly were or where their remains may still be seen, so that serially the new shoots arise below the old ones. During the first year, between the assimilationbranch and the scale-leaf subtending it, one may find the little bud which develops into a new year-shoot (fig. 25). Sometimes not one but several shoots are formed from a node, some of these being vigorous and persistent, while others are short-lived assimilating shoots. It has not been possible to determine whether these serial shoots are lateral shoots on an assimilation-branch of the first year, or on 
each other, or whether they are lateral shoots on the main shoot of the first year. The new shoots of the third year may again arise from the same nodes. Some of these may be plainly seen to be placed low down on the second year's shoot; others are situated further towards the end of it, at the nodes, in bunches or singly.

Eremosparton flowers in May or June. The flowers are red, short-stalked, and being arranged widely apart they form loose racemes. Even at the beginning of June fruits are found on the lower parts of the plant. The. flowers developed last do not seem to yield

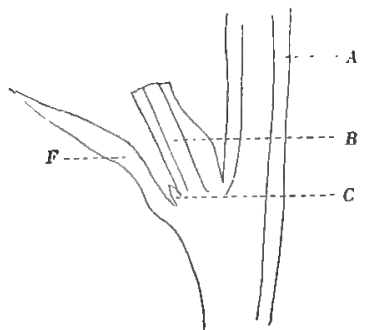

Fig. 25. Eremosparton aphyllum. Longitudinal section through part of a year-shoot $(A)$. This bears a leaf $(F)$, an assimilation-branch $(B)$ and a bud (C), from which a new branch will arise next year. $\times 11$.

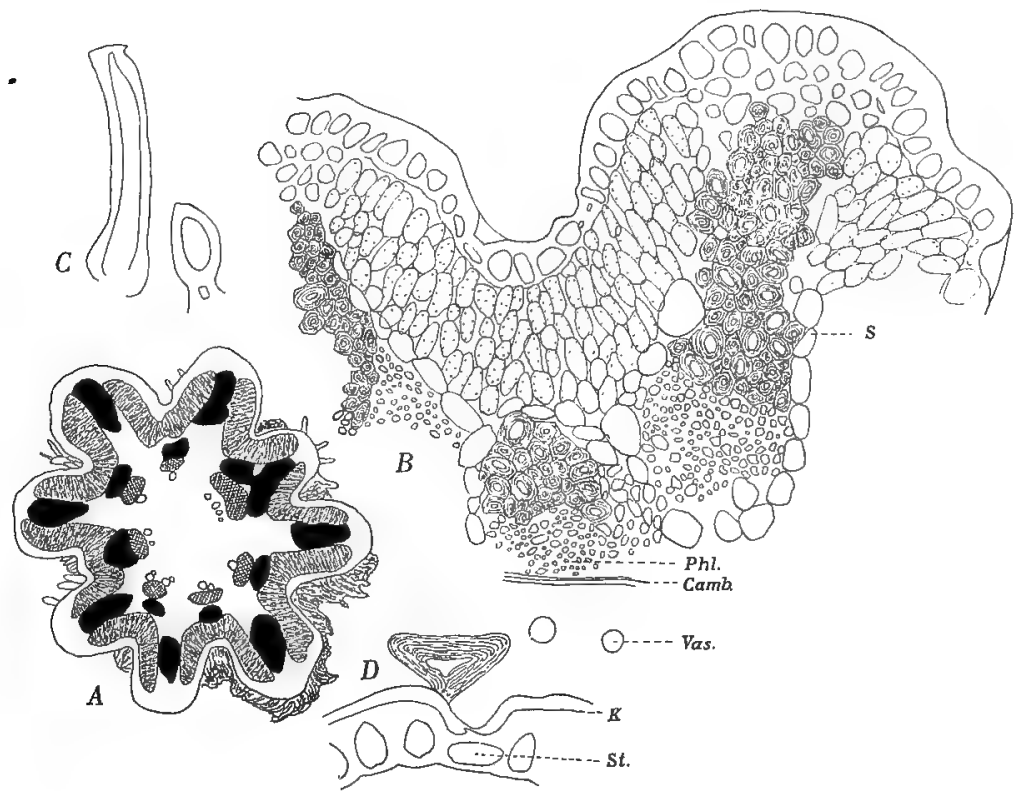

Fig. 26. Eremosparton aphyllum. A, Transverse section of year-shoot. Sclerenchyma shown black; palisade-tissue liatched in one direction; Vascular bundles cross-hatched. Dead hairs cover part of the surface. $B$. Detail of $A: S$, storage sheath; Phl., Phlœum; Camb., Cambium; Vas., Vessels. $C$ \& $D$, Hairs; $D$, shows a stoma (St), and $K$, inner limit of the cuticul. arised layer. $A, \times 47, B-D, \times 230$. 
fruit, probably they are burned by the heat of summer. The fruit is a crescent-shaped, one-seeded, woolly-haired pod about 1 centimetre in length and easily transported by the wind (see fig. 23).

The anatomical structure of the assimilation-shoots and the year-shoots is very similar, but the former have no cambium; Fig. 26 shows the inner structure. There are 8 or 9 grooves within which the palisade tissue lies in V-shaped tracts bounded towards the interior by a row of storage-cells. At the apex of each ridge there is a mass of collenchyma and deeper-seated is a band of sclerenchyma of which another band is found outside each vascular bundle. Stomata only occur in the grooves, they are slightly sunk and hidden by scale-hairs.

Calligonum Caput Medusae Schrenk.

A shrub or small tree, 1 to about 3.5 metres high and leafless. Its home is the sand-desert and it is extensively utilised in the plantations along the railway; $90 \mathrm{p}$. cent. of the cuttings strike root, and year-old plants from the nurseries always transplant successfully. Comparatively speaking the plant is distinctly green, but in this respect it is far behind the Salsola species.

The year-shoots are long (about 40 centimetres), thin and jointed. The leaves are scale-like and membranous, and form a sheath round the stem (Polygonaceae). All or most of the leaves subtend branches, the upper ones often flowers, the lower ones annual assimilation-shoots. Rindowsky $(1875$ l. c.) drew attention to the difference in Calligonum between "rami assimilationis" and "rami lignosi", see also B. Jönsson (l. c. p. 18). There is, however, no very hard and fast limit between the two sorts of branches. The outer part of the year-shoot dies away after the cessation of the vegetative-period, generally together with the branches. New year-shoots arise singly or several together from the leaf-bases of the old shoots, sometimes on branches several years old (see figures 11 and 27). Where several are present together, some are generally more strongly developed 
than the rest, and these become rejuvenescence-shoots; the others (secondary shoots) fall off at the end of the summer. They often bear flowers (fig. 28). The same leaf-bases may

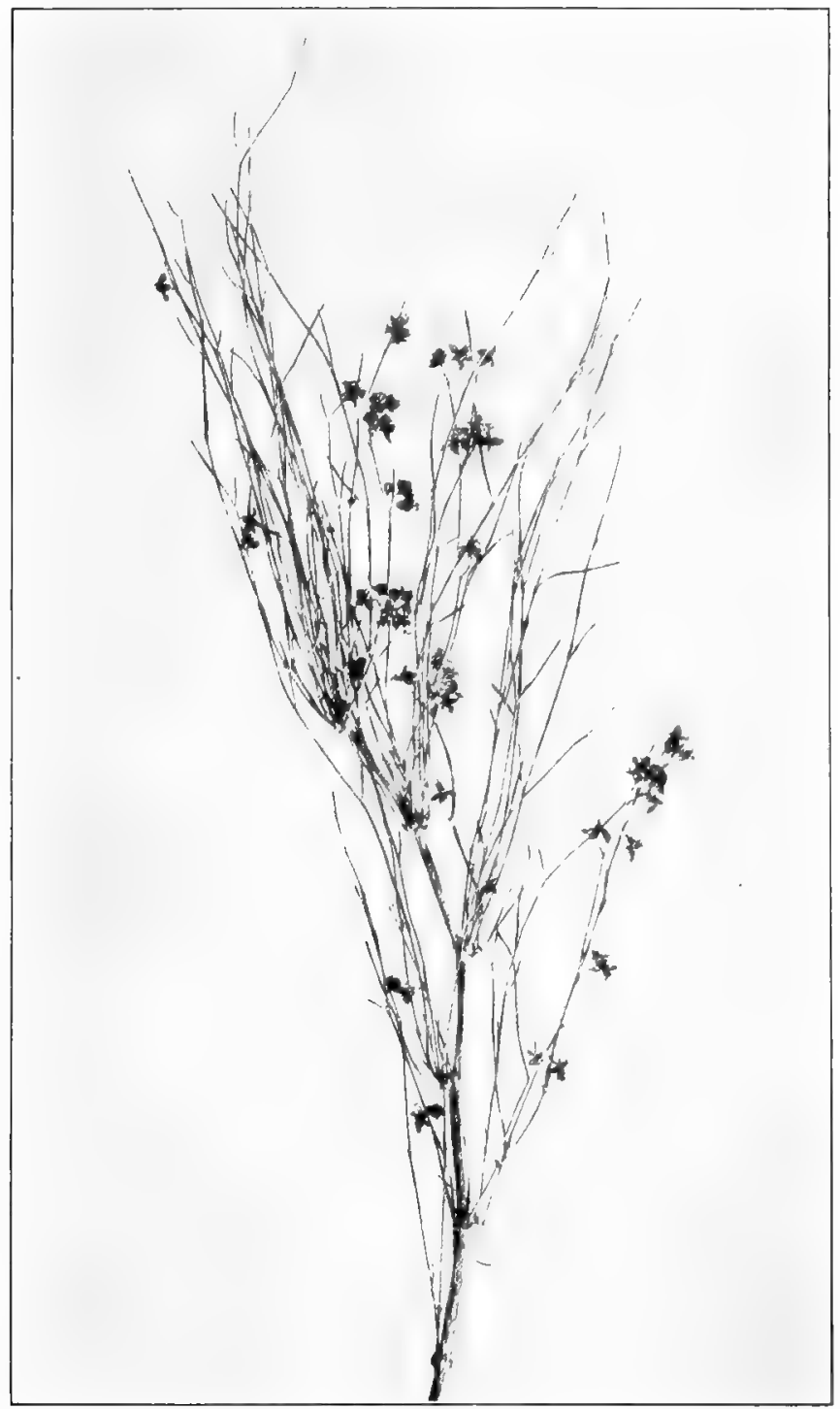

Fig. 27. Calligonum Pallasia.

Year shoot from last year with bunches of new, flowering branches. May. 


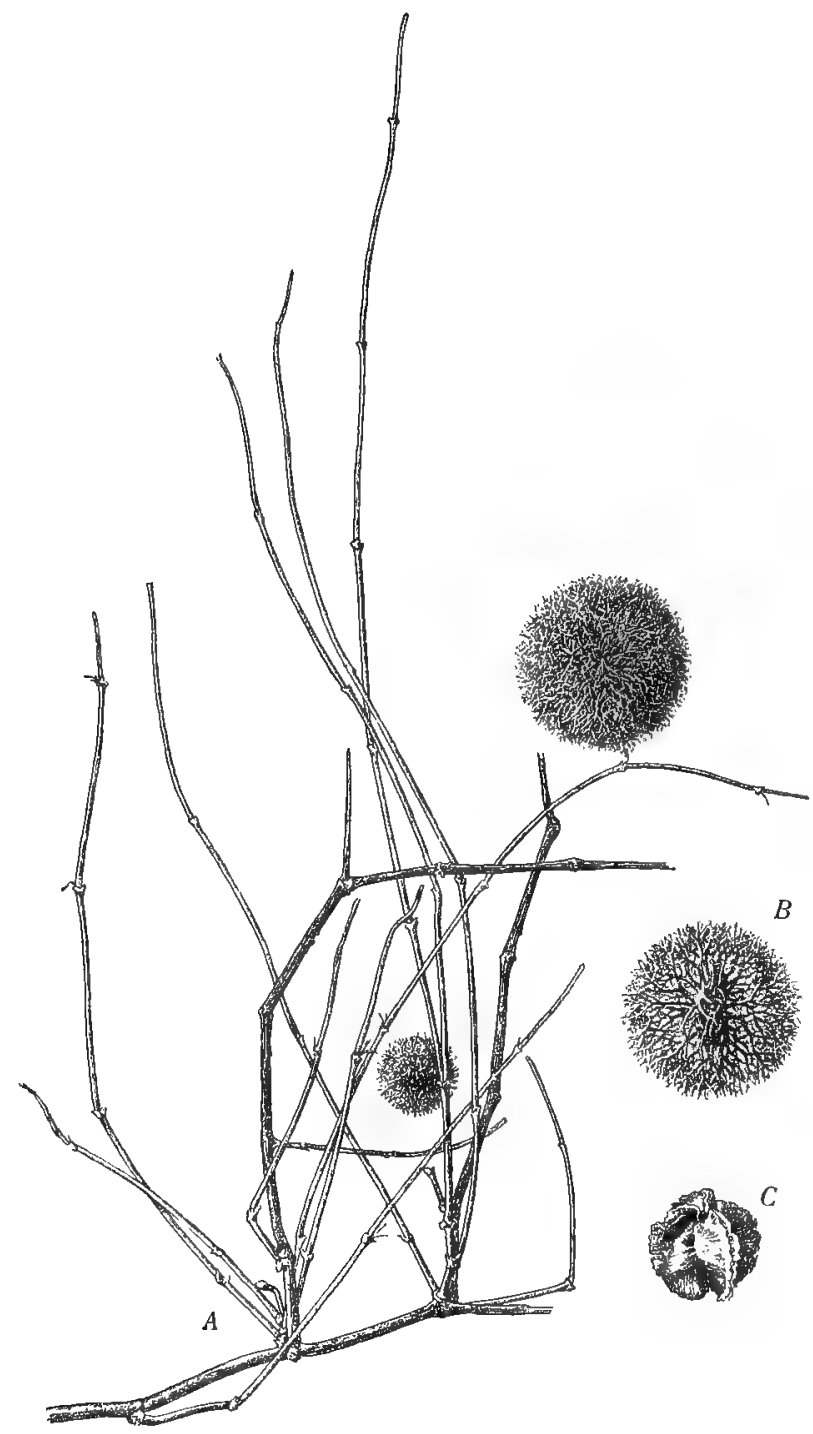

Fig. 28. Calligonum ${ }_{-}^{\infty}$ Capnt Medusae. June.

$A$, The horizontal two-year-old branch bears two year-shoots of last year, with the upper parts dead (strongly shaded); at their bases bunches of new shoots arise, while others are borne on more distal still living parts. The shoots now bear fruits, most of which have fallen. $B$, a fruit with the setae cut away from the side in view. C, a fruit of Calligonum Pallasia. 
produce annual assimilation-shoots several years in succession and by degrees a low cushion is formed from which others arise. Even nodes bearing year-old branching shoots, may again be seen to produce new shoots.

Calligonum Caput Medusae flowers in June. The flowers are small and reddish, the fruits (figures 11 and 28) are very characteristic (see above p. 88), they are easily transported by the wind and are found massed together in sheltered places in the desert.

As regards anatomical structure we refer to fig. 29; there are sclerenchyma bands below the epidermis 14 in number, two palisade layers of which the outer one is very loose, an

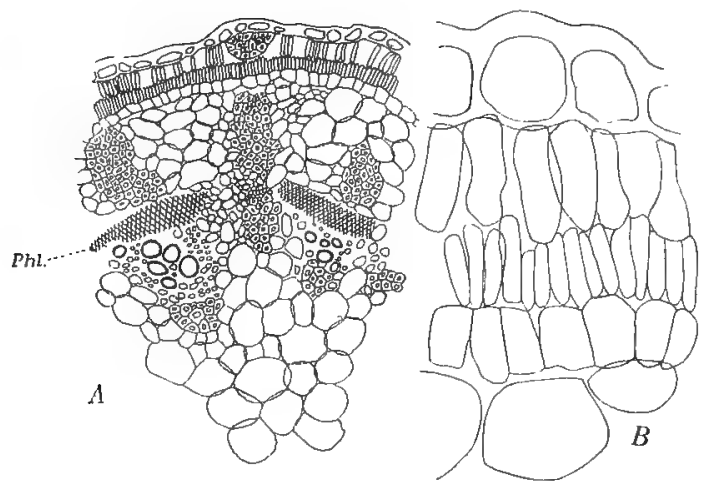

Fig. 29. Calligonum Caput Medusae.

$A$, Part of transverse section of a young branch: Phl., Phloem, $\times 71$. $B$, Detail of $A$ : epidermis, two palisade layers, starch sheath and outer cells of the water-storage tissue of the cortex. $\times 250$.

amyloid or starch sheath, and the inner bark formed of bands of sclerenchyma between which is aqueous tissue; this contains much tannin. Other bundles of mechanical tissue occur between the vascular bundles and between them and the pith. The pith is a large-celled, water-storage tissue containing tannic acid. The stomata are sunk. Volkens, who (p. 142) described the anatomy of Calligonum comosum found under the epidermis a layer of loose, thin-walled cells, but only one palisade layer. B. Jönsson, who examined an undetermined species from Turkestan, found on the con- 
trary a thick-walled hypodermal layer, and only one palisade layer.

With Calligonum Caput Medusae are related the other species of this genus which grow in Transcaspia, see the plant-list p. 154. Borszczow has described many species; as to the systematic value of these I have no definite views. Variations are especially common in the fruits, but there is also considerable variety in height and in usefulness as sheltering plants. PalezkiJ states that most of the species have a tendency to lose their branches in summer, a result of the heat of the sun. This shows itself first as rustcoloured spots which gradually make their way through the branches. Calligonum eriopodum is the species which suffers least from this injury, it is also of high stature and being hardy in several respects it is more extensively used in planting shelter-belts than the other species. Calligonum arborescens is also employed on account of its size, it is said to attain a height of 6 metres.

Calligonum plants are raised in the nursery; one-yearold specimens are about one metre high. They can only endure water as seedlings during the cotyledonary stage.

Under natural wild conditions Calligonum Caput Medusae and C. Pallasii (= Pterococcus aphyllus) seem to be the most common. The fruits of the latter have eight broad wings instead of tufts of setae (fig. $28 \mathrm{C}$ ). All the species have thin assimilation-branches.

Ephedra alata Dene. (= E. strobilacea Bge.).

I have seen this plant in the sand-desert as a shrub one foot high, but it is said to become much higher. Part of a stem I saw was 14 centimetres in circumference.

The leaves are membranous and sit three and three together at the joints. The year-shoots may grow long, they are placed laterally on the previous year-shoot, and arise one, two or three together. Some nodes may for several successive years be the starting point of new branches which thus form bunches. My notes include no other observations on the shoot-structure. 


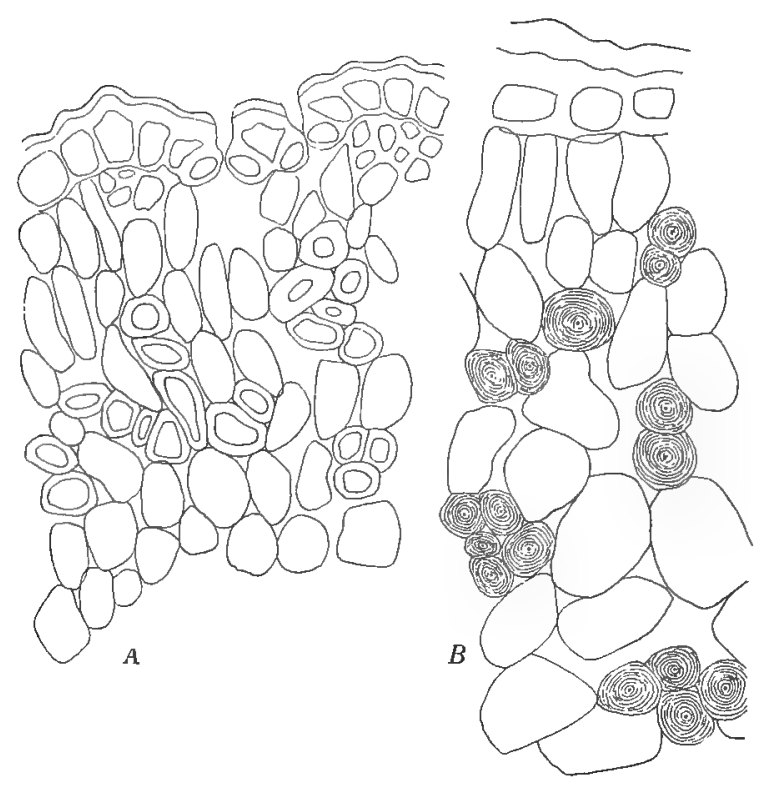

Fig. 30. Ephedra alata. A, Transverse section of bark of a young branch. $B$, T. S. of a year-old branch. $\times 230$.

The anatomical structure of the green bark is briefly described by Volkens (p. 151), and Ross (p. 17) describes an undetermined Ephedra species. Fig. 30 shows the assimilating cortex of a young and of a somewhat older branch. The outer wall is very thick with a strong cuticularised layer. The palisade cells become more rounded towards the interior and at the same time contain less chorophyll. Below the epidermis and in the deeper layers there are numerous sclerenchyma-cells which traverse the stem longitudinally; in the older branch their lumen has almost disappeared.

Ammodendron Conollyi Bge. (The Sand-Acacia).

This species is found in the sand-desert and prefers deep sand. It altains a height of $2-4(-8)$ metres and is a shrub (on the more stationary soils) or more frequently a slender and in most cases a one-stemmed tree. The hairiness of the leaves gives it a whitish grey appearance, the crown 
is very open and casts only a light shade. The ends of the branches are pendulous, long, thin, pliant and whip-like. Two branches are shown in Fig. 10. PalezkiJ has measured roots 19 metres in length.

The leaves are scattered and pinnate with two linearlanceolate leaflets densely coated with silky hairs. The rachis sometimes ends in a slender thorn one centimetre long, which frequently persists till the next year. Stipules are absent or represented by two small spines.

The distal part of the year-shoot probably always dies away before the next vegetative period, also when it is not an inflorescence, which is, however, generally the case (see fig. 10). The succeeding year-shoot arises from the middle part of the first year-shoot. Vigorous year-shoots may be branched, but there is no indication that we have here assimilating branches lasting only one summer. The plant has likewise true leaves.

The flowers are purple and are arranged in terminal racemes. Only the lower flowers in a raceme set fruit; these are also the earliest to develope (April): the later flowers are dried up by the heat of summer. The fruit-bearing branches in fig. 10 show the inflorescence bare above the fruits, and it is seen how few fruits there are compared with flowers.

The fruit is a yellow, one-seeded, indehiscent, winged "pod" which ripens in May. When ripe it is spirally twisted and this with its lightness enables it to be easily carried off by the wind. The seeds are very hard. According to Palezkis

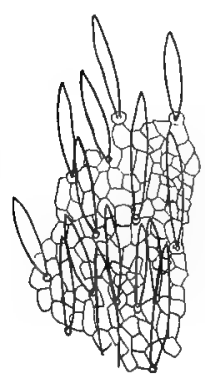

Fig. 31. Ammodendron Conollyi. Epidermis with hairs. $\times 53$. only 2 per ct. of the fresh seeds germinate but they can all be made to do so by cutting the skin. The leaves are isolateral in structure. The epidermis is thick with sunk stomata on both surfaces. Its coating of unilateral hairs is shown in fig. 31. There are about three layers of palisade cells on each side and hardly any spongy mesophyll. The veins have sheaths of hard bast.

As to the other Ammodendron species, $A$. Karelini is closely related to the species just described. A. Siewersii, which can hardly 
be distinguished from A. Lehmanni, is more thorny, the petiolar rachis-thorn being longer, while the stipules are always present as thorns. A. Eichwaldii is a stunted, closely branched shrub with two pairs of leaflets. Biologically these species are closely related.

\section{Ammothamnus Lehmanni Bge.}

This I have not examined in its habitat, and only know from herbarium-specimens and descriptions. It is a shrub scarcely attaining the height of one metre. The leaves which have small linear stipules are long and pinnate with $7-13$ leaflets. These are obovate, cuneate at the base and broad, but small (less than one centimetre long). They are green, but like the year-shoots are provided with stiff hairs. The distal part of the year-shoot dies away (always?), and the new shoots arise from the apex of the surviving part. The white flowers are arranged in a raceme, they come out in April. The fruit is a long velvet-haired pod, spirally twisted, and containing many seeds.

The leaves are isolateral in structure with stomata on both sides, 3-4 layers of short palisade cells on each side and almost devoid of spongy mesophyll.

\section{Smirnowia turkestana Bge.}

A shrub attaining the height of about 1 metre. It is a true desert-plant and is most frequently found on clayey soil. The outer bark peels off the older branches in long shreds and then the branches turn yellowish. A coat of hairs makes all the younger parts look greyish. The leaves are simple and almost circular with a diameter not exceeding 1,5 centimetres. As a result of the petioles turning or bending, the leaves assume a vertical position.

The year-shoots are branched, many of the axils bearing rather short leafy branches which only live through one vegetative period; they are thus true assimilation-branches. The distal part of the year-shoot itself is also annual; sometimes only a very short piece at the base survives. The 
new year-shoots arise on the surviving part beyond and below the dead assimilation-shoots, their buds may as in Eremosparton be found the year before; several successive series of new year-shoots may arise from the same place, so that they are arranged in bunches.

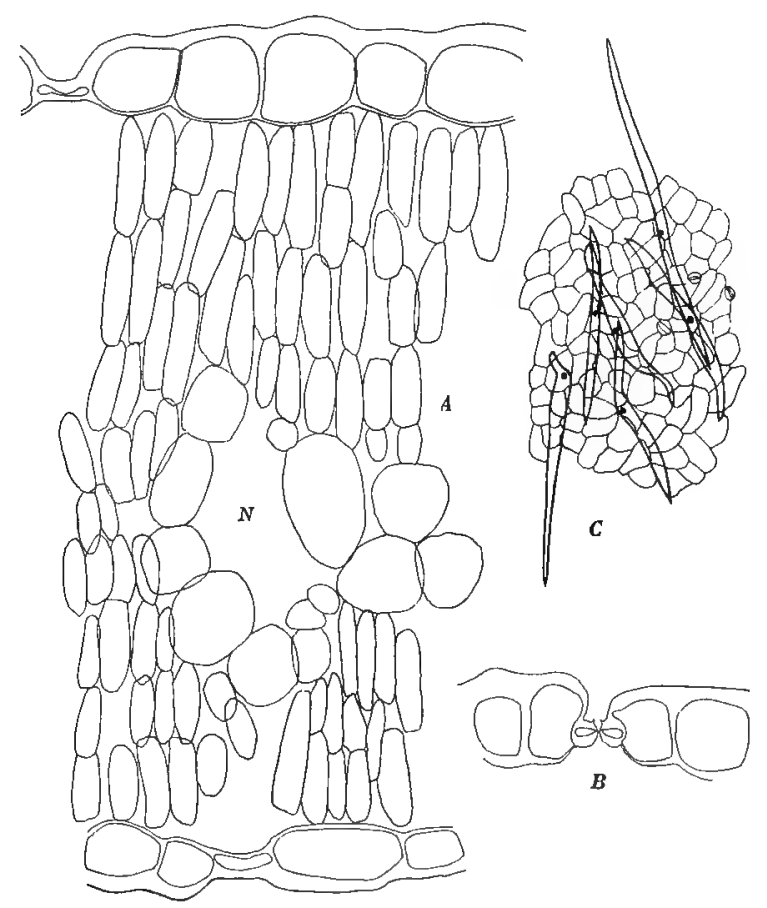

Fig. 32. Smirnowia turkestana. A, Transverse section of leaf: $N$, vein. $B$, a stoma. $C$, epidermis with bipartite hairs. $A$ and $B, \times 220 ; C, \times 53$.

The flowers are arranged in few-flowered racemes which are placed lateraliy on the year-shoots.

The fruit is an inflated hairy pod $2-3,5$ centimetres long, it contains about 3 seeds which are hard-shelled, flat and reniform; as the pod is swept along by the wind, the seeds may be heard rattling inside.

The structure of the leaf is isolateral (fig. 32) with stomata on both sides, and 3-4 layers of palisade cells filled with starch on the upper side and about the same number 
on the lower side. Round the veins, which are numerous, there are rings of large translucent cells between which there are very narrow bands of chlorophyllous tissue.

Astragalus unifoliatus Bge.

A shrub attaining a height of until 0,7 metre. It is strongly branched, the branches being spread out and crooked. The bark of older branches shows a network of fibres. The green parts are densely coated with greyish or whitish hairs. The leaves are small and pinnate with four leaflets at the beginning of the vegetative season, but later they are ternate or only single-leaved. Towards summer most of the leaflets fall off and the rachis remains like a wooden peg $0,5-2$ centimetres long, later during the summer it likewise withers. The leaflets are elliptical or lanceolate and small, generally no more than a centimetre long, but occasionally they may be 2 centimetres. The stipules are connate, clasping the branch.

Part of a young year-shoot is shown in fig. 33 where the branching is seen. Sometimes the branches again produce lateral shoots. These branches are assimilating shoots which do not persist. In their place one or more new shoots will arise next year so that here again, sometimes in a very marked degree, we find branches arranged in bunches.

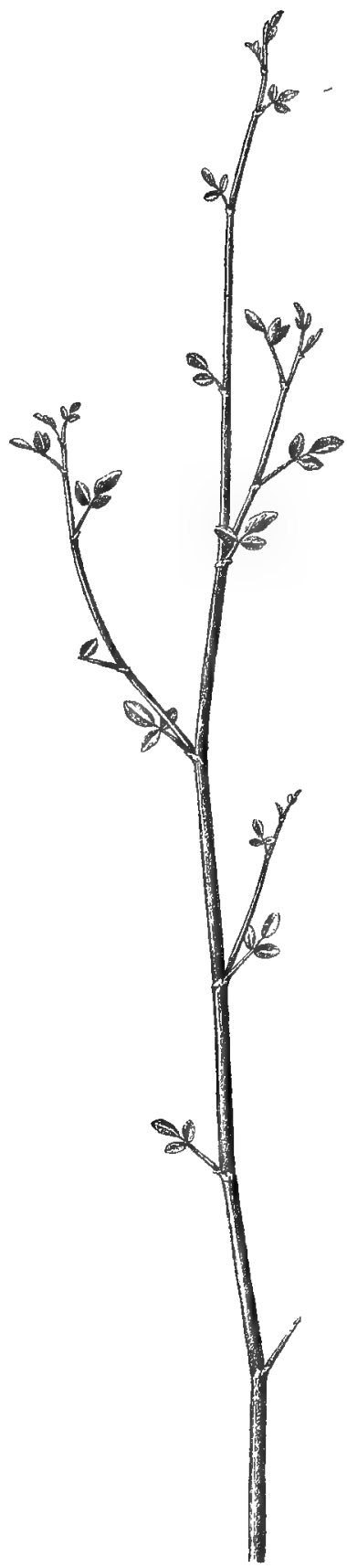

Fig. 33. A year-shoot of Asiragalus unifoliatus (red.) June. 
The small red flowers which appear in May or June are arranged in small terminal racemes. The fruit is a pod, $6 \mathrm{~mm}$. in length, densely coated with white hairs and containing $1-2$ seeds.

The leaf is isolateral in structure. The epidermis is covered with bipartite hairs on short bases, and has stomata on both sides, not sunk. There are 2-4 layers of palisade cells (filled with starch) on each side, and 1-3 layers of translucent cells surround the veins. The larger veins have sclerenchyma on the phloem side. Sometimes, though rarely, lignified bast-cells issue from this bast-sheath and traverse the palisade layers till they reach the epidermis (fig. 34). "Speichertracheïden" are found in great numbers in the mesophyll. Among the palisade cells are a few translucent, globular bodies which seem to consist of mucilage.

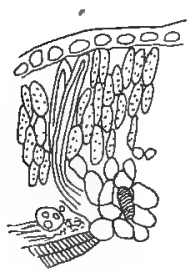

Fig. 34. Astragalus unifoliatus Part of transverse section of leaf with sclerenchyma and a "Speichertracheïde" $\times 71$.

The green bark of the young branches has about 4 layers of short palisade cells below a single-layered, hairy epidermis. Bast bundles are found outside the vascular bundles.

Closely related to Astragalus unifoliatas are a number of other shrubby species of Astragalus e. g. A. Ammodendron, paucijugus, hyrcanus, villosissimus, macrocladus, brachypus, squarrosus. All belong to the section Ammodendron which is characterised by connate, clasping stipules, by a small inflated hairy and few-seeded pod and by the frequency of persistent petioles. The section belongs to the sub-genus Cercidothrix, characterised by bipartite hairs. A. brachylobus with the same type of fruit, and $A$. sleroxylon with linear, curved pods also belong to this group.

All the species named are early flowering shrubs or dwarf shrubs with a few small and hairy leaflets. In some of them the petiole persists till next summer though dead, thus in A. paucijugus, hyrcanus, villosissimus, squarrosus and perhaps others; in the first-named it attains a length of about 30 centimetres. The shoots are often curved and the bark in older branches is fibrous. In some of them the 
branches are arranged in bunches (A. Ammodendron, hyrcanus and perhaps others).

My knowledge of these Astragalus-species is mainly derived from literature and herbarium material.

Halimodendron argenteum D. C.

A shrub attaining a height of about 2 metres, which prefers clayey soil. It is also common in the neighbourhood of rivers and is often met with in oases, by roadsides and such places. It has long, horizontal roots from which aerial shoots issue at long intervals.

The year-shoot seems to become completely lignified and to remain alive throughout its whole length. The primary bark is green, the secondary brown. Within the bark and surrounding the branch there is a circle of six large bast-bundles (fig. 35), three larger ones on

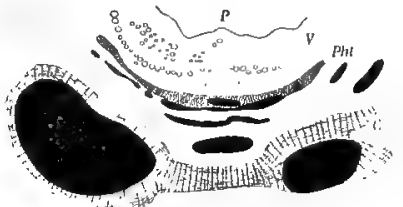

Fig. 35. Halimodendron argenteum. Part of transverse section of a year-old branch: $P$, Pith; $V$, Wood; Phl., Phloeum; C. Cork. The black part is sclerenchyma. The largest sclerenchyma-band belongs to a leaf-rachis thorn, the next largest to a stipular thorn. $\times 24$. one side corresponding to the nearest leaf above with its two stipules, and three smaller ones on the other side corresponding to the next but one set of leaves higher up. All the bundles disappear at a distance about $1 \frac{1}{2}$ nodes below the leaf from which they issue. The lower part of each node of the stem has therefore only three bast-bundles. The rachis of the leaf and the stipules form thorns, and the larger bundles of sclerenchyma in the bark are the downward prolongations of the thorns. The intervening spaces are not quite regular as the leaf-arrangement is a $2 / 5$ spiral. The structure of the bark (and the pith) has been described by B. Jönsson (p. 31) who has found mucilage-cork and air-lacunæ; I have not examined these. Jönsson calls the persistent leaf-rachis a thorn-branch bearing leaves arranged in pairs and accompanied by secondary thorns. The real condition is that the leaves are pinnate with four cuneate leaflets. The rachis remains as a thorn 
which may attain a length of more than 4 centimetres, and this is accompanied by two smaller stipular thorns. The

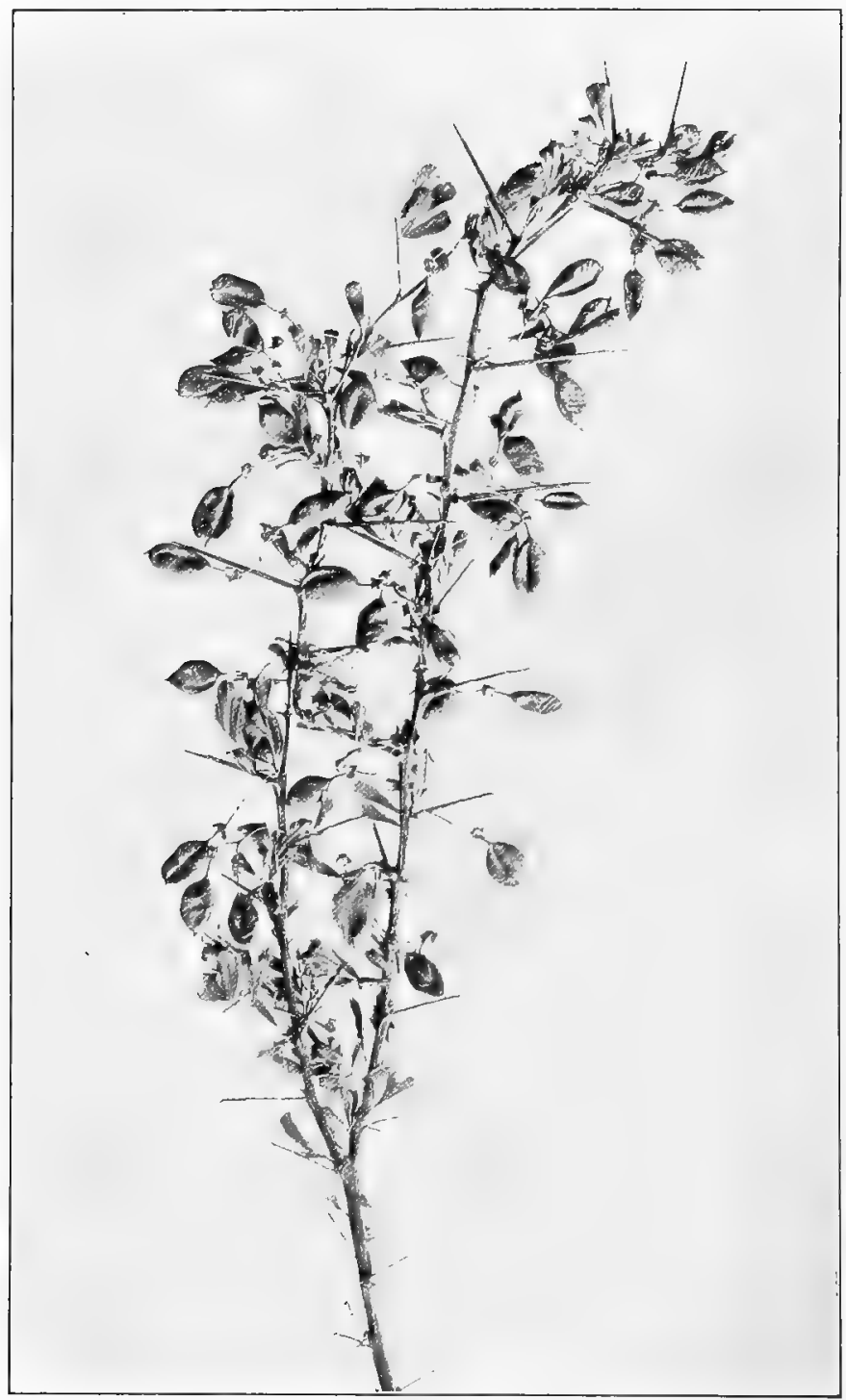

Fig. 36. Branch of Halimodendron argenteum. A new year-shoot is seen at the top of the left-hand branch. Other flowering (now fruit-bearing) short. shouts arise from each leaf-axil on the shoot of the previous year. End of May. 
leaflets are silvery haired and motile since by curvature of the peliole they can assume a vertical position.

On the year-old shoot (see fig. 36) short-shoots arise in the leaf-axils, they bear flowers two together on a slender, furcate stalk. These open in April or May, and by the end of May ripe fruits occur. The fruit is a hard, few-seeded, inflated pod, 1-2 centimetres long, placed on a short gynophore (fig. 36). Owing to ils lightness, hardness and roundness the fruit may roll a long time before the wind without being injured.

The anatomy of the leaves has been described by $J$. WEYLAND and B. Jönsson. I have found the same structure as these authors, but like WeyLand I have not seen the hypoderm on the underside of the leaf which Jönsson ligures. The leaf is isolateral, with about three layers of palisade cells containing starch on each side, a translucent tissue of rounded cells, and strong sclerenchyma bands along the veins. On each side the stomata are slightly sunk. The leaf, like the bark, contains numerous tannin cells lying almost exclusively amongst the palisade cells, but different in shape.

Ewersmannia subspinosa (Fisch.) Fedtsch.

A low shrub occurring at least in the northern part of the territory dealt with here, but which I have not seen growing. The bark of the branches is fibrous. The leaves are two-rowed, pinnate with 9-11 leaflets half a centimetre long; they have small membranous stipules each of them subtending two thorn-branches one of which is generally longer than the other. The flowers arise from the longer thorn-branch which attains a length of $3-4$ centimetres, they appear in May. The fruit is a lew-seeded, flat pod with one or more $S$ curves; it is carried swiftly by the wind.

\section{Prosopis Stephaniana Spr.}

A small strongly branched shrub which attains the height of about half a metre. It seems to thrive best on sandy clay. 
The leaves are bipinnate with about 10 leaflets on each pinna, these are $3-9 \mathrm{~mm}$. long, oblique, hairy and when the sun shines they are directed upwards. Older branches have white bark and are covered with prickles.

The year-shoot is branched. During the same year each axil gives off either an inflorescence or a branch, or two bran-

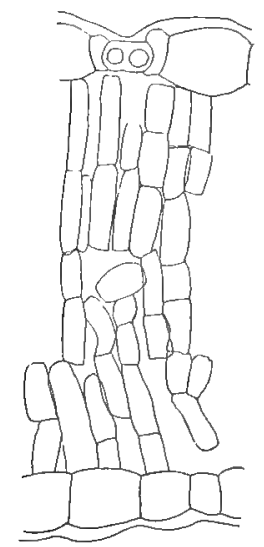

Fig. 37. Prosopis Stephaniana. Section through the leaf. $\times 230$. ches, or a branch and an inflorescence. The longest year-shoot branches are about 15 centimetres long at the beginning of June and only the outermost 2 centimetres are not fully lignified. The year-shoot branches bear many leaves which often subtend inflorescences, but apparently no new branches. The year-shoot branches cannot be termed assimilating shoots as they are persistent. Prosopis flowers from May to July. The inflorescences are long racemes with small flowers. The fruit is a fleshy pod $3-4$ centimetres long.

The leaf is isolateral in structure (fig. 37). The epidermis contains tannin and has stomata on both surfaces; $6-7$ layers of palisade cells fill up the whole leaf. The veins have bast sheaths on both sides. "Speichertracheïden" are present.

\section{Zollikoferia acanthodes Bois.}

is said to be a stunted thorny shrub with forked angular branches and with thorn-like short-shoots. A few ovate or oblong leaves occupy the base of the branches, they are thickly coated with white spines and soon fall off. (From Borssier fl. orientalis.)

\section{Atraphaxis spinosa L.}

A strongly branched shrub never exceeding a height of one metre. The leaves are shortly petiolate, circular-ovate, rather thick and about one centimetre long. The bark is 
white. The distal part of the year-shoot dies before the next vegetative period but persists as a point often thorny. The year-shoots may be branched and are often twice branched. The inflorescences are short racemes placed on branches of secondary order. Under unfavourable conditions, for instance on rocky ground, no long-shoots are formed but only shortshoots. (A. compacta).

The white or reddish flowers appear in April or May. The fruit is a nut enclosed in the three-winged perianth.

\section{Salsola Arbuscula Pall.}

A characteristic and very variable plant. Its varied aspect was described and illustrated so long ago as 1833 by Eichwaldt. On clay it is a stunted, twiggy, stiff shrub with short shoots and hard stiff leaves. But where it occurs on moving-sand it may become a small tree with long pliant shoots and leaves. In the sand-desert it varies in pliancy and hardness, in length of shoots, and in hairiness of shoots and leaves. It has very long roots which in the dune-valleys may be seen exposed and stretching from dune to dune, thus showing that some at least are horizontal.

The best developed form (var. angustifolia $\mathrm{Fzl}$.) will be considered first (fig. 12.) As a tree it attains a height of 3-5 metres, with foliage greener and denser than that of any other desert-plant in these parts; the stem is light-coloured and elegant. It appears thus on the moving-sand, and here also may be found specimens with fasciated branches, a character which often accompanies luxuriant growth.

Salsola Arbuscula is one of the most important plants for sand-binding purposes along the Transcaspian railroads. Small pieces of the stem are stuck into the sand and of these 100 per ct. germinate, but many of them are injured by lepidopterous larvæ. In the course of two years the plants attain a height of about 3 metres. The hardihood of the plant in withstanding sand-drift has already been considered (p. 88).

In vigorous specimens from the sand-desert the leares are 7 centimetres long or rather longer. They are cylindrical 
almost filiform, and pendulous. The year-shoots may attain the length of half a metre, they are always branched, often twice branched. The bark is green at first, but soon turns white and glossy.

The distal part of the year-shoot often dies away before the next vegetative period. The new year-shoots arise close up to the dead part, the lower part of the old year-shoot being branchless.

The year-shoot generally bears flowers towards its apex; a flower is placed in each axil and the length of the internodes decreases upwards. In less luxuriant plants the branches are formed high up, and arise in the axils below the lowest flowers. These branches have rather short nodes, bear flowers in every leaf-axil and die away after the ripening of the fruits. They are thus annual assimilating as well as flowering shoots. In more vigorous plants the branches of a year-shoot are long, drawn out and zigzag, they are also numerous as they arise from almost every leaf-axil on the year-shoot (fig. 12). In the most strongly developed specimens the branches of the year-shoot are lignified, and are then scarcely assimilating shoots but rejuvenescence shoots. They may bear flowers in each leaf-axil or only in the upper ones, and as a rule they have flowering branches towards the apex.

The year-shoot branches of secondary order are similar to the primary branches described above for the more feebly developed plants; they are llower-bearing, with short internodes, and quickly perish.

The year-shoot branches which bear flowers throughout their whole length - such as those in fig. 12 - live, to all appearances, only one vegetative period, and one often finds dead ones bearing the scars of fruits, they are thus assimilating and flowering shoots; on the other hand, the year-shoot branches, which bear leaves at the base, become so strong and thick that the lower part probably survives the winter. The tips of the branches, however, which in September are soft and still growing, probably die away like the tips of the main shoots.

The small form of Salsola Arbuscula which prefers a 
clay soil is a dwarf shrub attaining a height of 30 - 501 centimetres; a branch of it is seen in lig. 38. The leaves are 1 or perhaps '2 centimetres long, thick and erect, fresh green and often coated with fine selaceous hairs (comp. pp. 70 \&

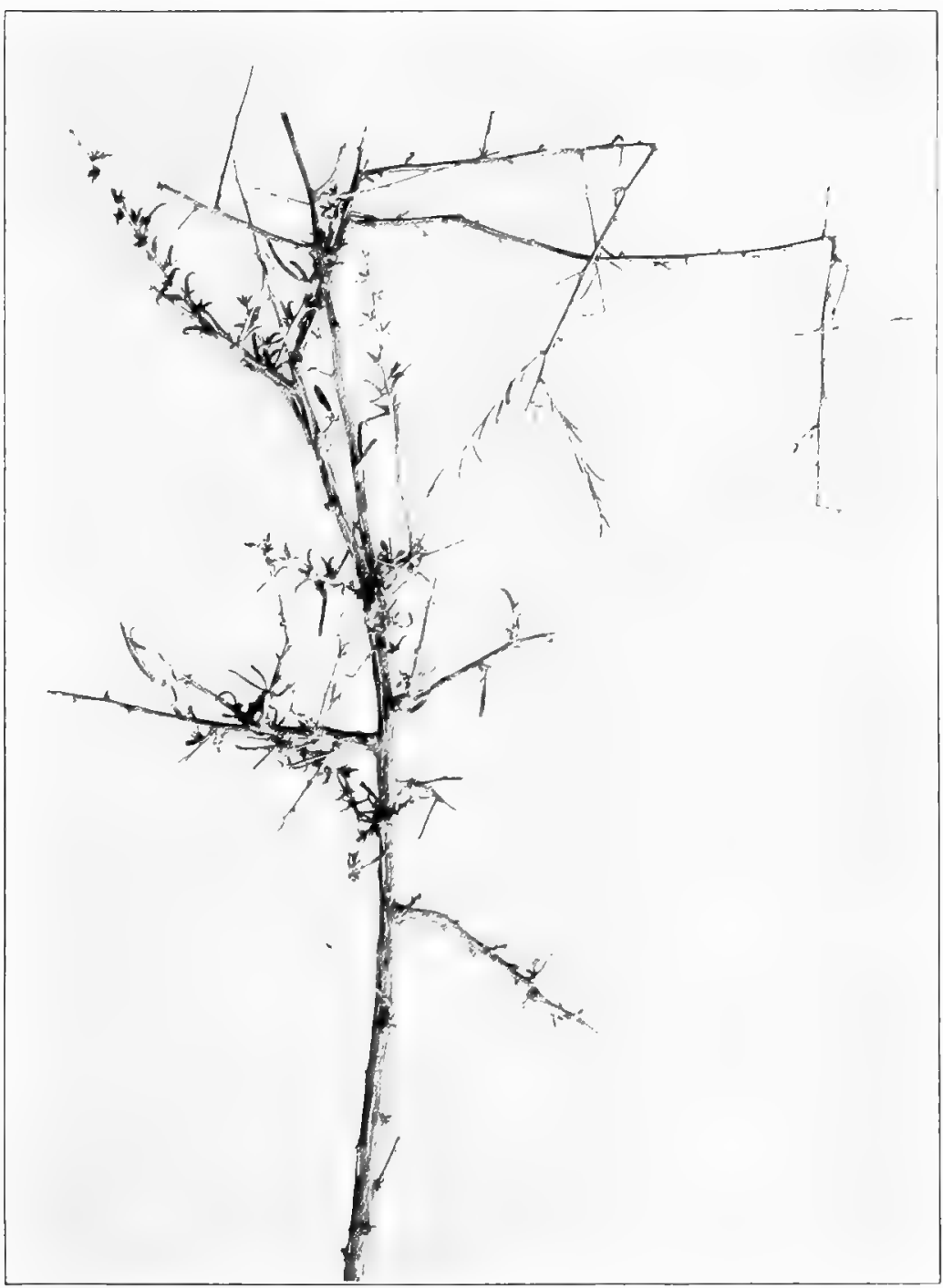

Fig. 38. Salsola Arbuscula. Clay-desert form. June. (The upper branches are broken and bent to one side, and do not show the natural habit). 
88). The year-shoots are erect, stiff, 3 to 7 centimetres long and frequently bear flowers in the upper axils. The distal flower-bearing part of the year-shoot generally seems to die away, though it is lignified and remains as a dry and almost thorny point. The next series of year-shoots arise lower down on the older one, and as these in turn lignify and die away at the tip, a system of short stiff branches is produced spreading in all directions. New shoots may also arise on branches several years old.

The flowers in Salsola Arbuscula are inconspicuous as in other Chenopodiaceae. Some open in June and July, but the

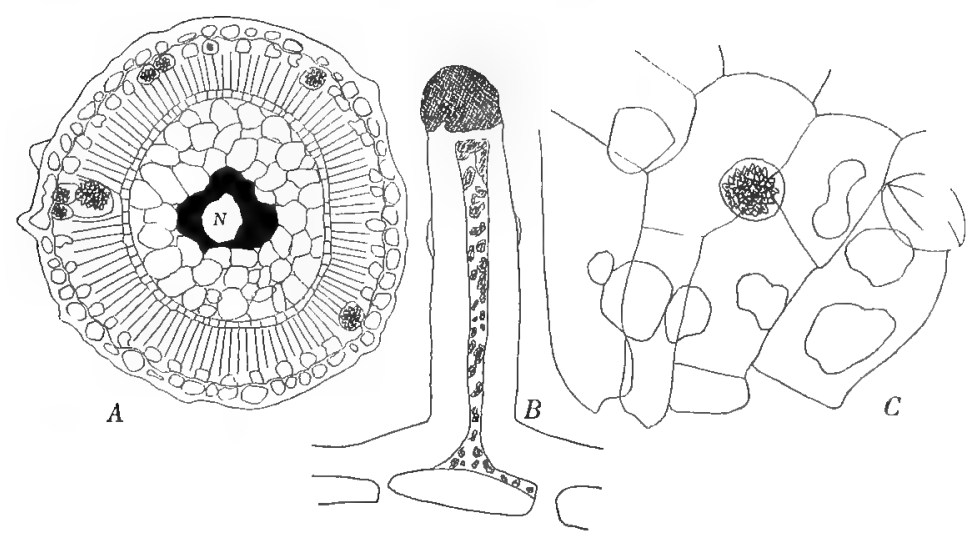

Fig. 39. Salsola Arbuscula.

$A$, Cross section of a leaf: $N$, vein; sclerenchyma shown black. $B$, Hair. $C$, Surface vicw of a leaf: beneath the epidermal layer the cells of the crystal-layer are shown, one of them with a group of crystals. $A, \times 47$; $B$ and $C, \times 202$.

majority in August or September. The flower is surrounded by three leaves; in front a subtending foliage leaf with a spoonshaped base, and at each side a broad thick green prophyll or bract, sometimes scale-like, and sometimes with a short blade. The perianth-segments are thick-walled on both surfaces; before and after anthesis they fold together forming a pyramid in which the stamens and carpels are enclosed. Such is the proteclion of these late-expanding flowers. The fruit (a nut) remains enclosed in the perianth the five parts of which - form a broad horizontal wing. The fruit is not ripe till 
October. Being light and provided with wings it is easily carried along by the wind.

The leaves are centric in struclure, of the type so often described, with a palisade layer and a starch sheath towards which the veins pass obliquely through the central aqueous lissue. (See Volkens p. 138). The vein is surrounded by sclerenchyma (fig. 39).

Between the epidermis and the palisade cells is a layer of cells with very thin walls and large intercellular spaces (fig. 39 A and C). Some of them contain clusters of crystals, also described and illustrated by Volkens (tab. XII, 3). This crystal-layer appears to be distinct from the epidermis but it may be compared with the corresponding one in $\mathrm{Hal}$ oxylon (WARMrng 1897 p. 218). where it is included amongst the epidermal tissues, and in both cases it may probably be regarded as a hypoderm; there must be air between its cells.

In var. longifolia the leaves are perfectly cylindrical; in the stunted form they are often slightly concave or flat on one side.

\section{Salsola subaphylla C. A. M.}

A shrub or small tree attaining a height of about 2 metres. It somewhat resembles the last species, but does not attain the same height, its foliage is less dense, and it sets fruit earlier. According to PaLEzkiJ its life-period does not at the most exceed four years, hence it is not employed for sand-binding purposes. It is by preference a sand-plant and attains its highest development where the sand is moving. On clay or stony soil it appears as a small shrub of about 30 centimetres high.

The leaves (fig. 13) are thick, cylindrical or half-cylindrical and attain the length of about two centimetres.

The year-shoots are branched, sometimes twice. The distal parts of the year-shoots and branches are in the month of July covered with flowers (fig. 13) subtended by scale-like bracts; the fruit-bearing branches may be quite hidden under the broad wings of the numerous fruits.

After the cessation of the vegetative period the tips and 
all the branches of the year-shoots generally die; the new year-shoots arise on the outermost living part of the old

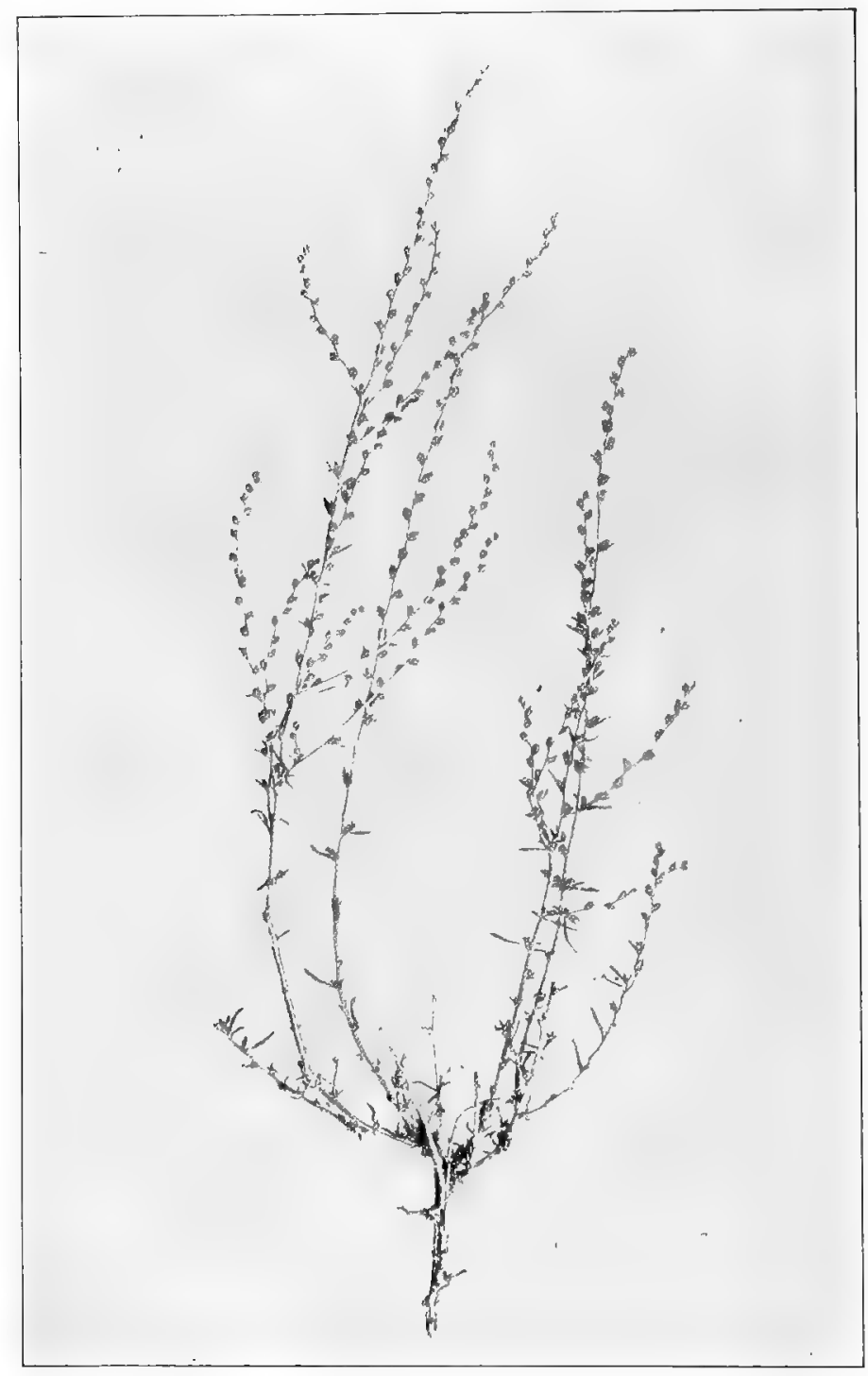

Fig. 40. Salsola rigida. Branched and flowering year-shoots of the present year arising from the bases of older branches of which the dead tips are seen. June. 
ones, beyond the year-shoot branches of last year, and from buds which may be seen the preceding year.

The flowers and fruits are very similar to those of the last species.

The anatomy of the leaf is also similar to that of Salsola Arbuscula, but the crystal-layer below the epidermis is absent.

$$
\text { Salsola hispidula Bge., }
$$

which I have not seen, is according to descriptions very much like S. subaphylla.

\section{Salsola rigida Pall.}

A stumpy shrub attaining the height of 30 to 50 centimetres, and almost an undershrub. It is one of the characteristic plants of the clay-desert (p. 69). The leaves are cylindric, and although the lower ones disappear in July, foliage leaves are present through the whole summer. The whole plant is hairy and grey.

The year-shoots, which may be 30 centimetres long, bear flowers in all the axils at their extremities and here in this region there are generally a few curved, ascending branches (fig. 40). In the axils lower down, vegetative shortshoots are frequently present, which probably next year develope into rejuvenescence shoots. The distal parts of the year-shoot and the flowering branches die away before the next vegetative period.

The flowers are hidden belween three bracteoles and open in June or July; the fruits are of the ordinary Salsola type and ripen in the autumn.

The anatomy of the leaf is the usual type. Central aqueous tissue, palisade cells with starch-sheath towards which veins pass from the midrib; the hypodermal crystallayer consists of scattered thin-walled cells.

$$
\text { Salsola laricina Pall., }
$$

which I have not seen alive, resembles the preceding species as regards ramification. 
Salsola verucosa M. B.

A shrub attaining the height of about one metre, and most frequently found in the clay-desert. The cylindrical leaves soon fall off, and during summer the main assimilating organs of the plant are the subtending leaves and bracts of the flowers which as fleshy, spoon-shaped scales, three together enclose the flowers. The plant is thus what we have called (p. 71) a bracteole-succulent. Small globular shortshoots with 3 to 5 leaves are sometimes seen replacing the flowers.

The year-shoots are branched, sometimes twice branched.

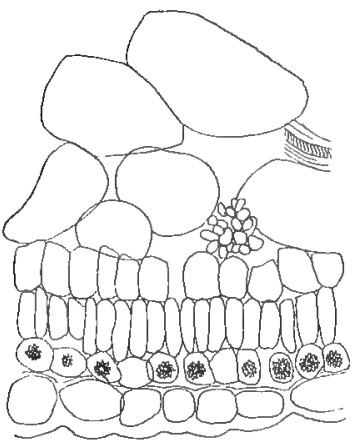

Fig. 41. Salsola verrucosa. Transverse section from the underside of a bracteole. $\times 202$.

The branches, especially those of secondary (or tertiary) order bear flowers so close together that the branches are hidden. The tips of the year-shoots and all the secondary branches die away before the next vegetative period.

Salsola verrucosa flowers in summer. The fruit is of the ordinary Salsola type.

The anatomy of the foliage leaves was not examined. The bracteoles have green tissue of the usual type on the outer (under) side (fig. 41). On the inner (upper) side the aqueous tissue is bounded by a thin epidermis.

Haloxylon Ammodendron (C. A. M.) Bge. (Saxaul).

A shrub or tree thriving best on sand with a subsoil of clay or lime. It may become very old (see B. Jönsson p. 8) and may attain considerable dimensions, but large specimens are rarely found as they are cut down for firewood by the nomads (comp. above pp. 89 and 126). I have seen a thickstemmed tree which I estimaled at 7 metres high. Artchison records a tree 14 feet high with a stem 12 feet in circumference. The wood is known to be hard and heavy, and old stems have deep irregular furrows. The roots are long, 
Palezirid says about $10^{1 / 2}$ metres and more, and Jönsson states that Saxaul has both deep-seeking rertical and long horizontal roots. The latter, according to AnTonow (p. 29), can form aerial shoots.

On account of its slow growth Saxaul is not much employed in sand-binding plantations. Yet, as stated above (p. 89), Lipsky denies that the growth is very slow.

The leaves are reduced to small scales arranged in pairs opposite each other and united together. The young branches are long, slender and drooping (see for instance BEsser, pl. 10, Lipsiry 1911 pl. 4 and 5).

The year-shoot is green, its bark containing the only assimilating tissue of the plant. Most of the shoots are set together towards the apex of the previous year-shoot, the distal part of which frequently dies away. Sometimes two shoots of the same age are seen in the same leaf-axil, one outside the other, but the outer one is generally more feebly developed, and it is improbable that both of them ever persist. The year-shoots are branched and they bear flowering short-shoots (see fig. 14).

The flowers are inconspicuous and open in May. Each flower is protected by its subtending leaf-sheath and by two bracts. The perianth, on the contrary, is small before the anthesis but afterwards it grows larger. The fruit is a small nut loosely enveloped by the broad-winged perianth, and is ripe in October.

The anatomy of Haloxylon has been described by GERNET, GheorghiefF, Warming and B. Jönsson. The structure of the assimilating shoot I found to be quite in accordance with that described and illustrated by WARMing (1897, p. 217), it is of the ordinary centric type. The epidermal tissue is threelayered. Assimilating tissue is also said to be present in the secondary bark. (B. Jönsson p. 7). As regards the mucilaginous cork in the bark mentioned by Jönsson, we refer to his memoir.

Halostachys caspica (Pall.) C. A. M.

A shrub which belongs to the clay- and salt-desert. Under specially favourable conditions it may attain a height 
of two metres, but in the desert it does not as a rule exceed half a metre. The shoot is of Salicornia type with reduced scale-like opposite leaves. The position of the branches is also regularly opposite (decussate or brachiate).

The year-shoot ends in a large paniculate inflorescence which is still present next year in a more or less dead condition. Underneath the inflorescence the year-shoot bears many branches; some of these are assimilating shoots which fall

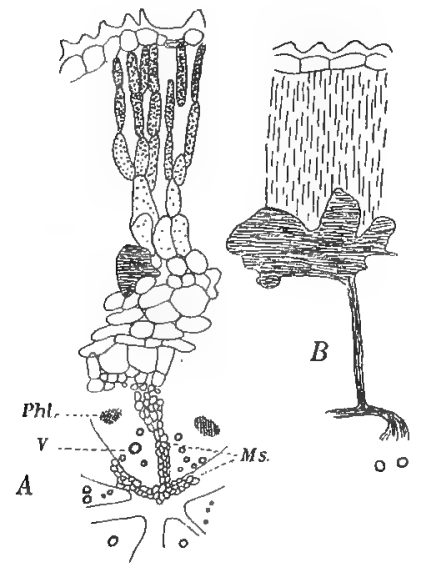

Fig. 42. Halostachys caspica. $A$, Part of transverse section of an assimilating branch: $N$, vein; Phl., phloem; $V$, vessel; $M S$, medullary rays. $-B$ shows a vein leading from the central cylinder to the palisade tissue. $\times 47$. off before the next vegetative period, while others are persistent rejuvenescence shoots. New assimilating shoots arise both from the old and the new yearshoots in places where vegetative or inflorescence-branches were formerly present, and sometimes two branches issue from the same leaf-axil.

The flowers are small, and sit three together in the axils of peltate bracteoles; they open in July. The fruit is a nut $(3 / 4 \mathrm{~m}$. m. long) enclosed in the enlarged perianth; it may still be found on the plant in the following year.

The green assimilating bark is enclosed in a one-layered, strongly papillose epidermis (fig. 42). There are about 5 layers of loose palisade cells of which the outermost contain the greatest, the innermost the smallest number of chlorophyll grains. Underneath the palisade cells there is no starchsheath, but numerous veins are spread out there (fig. $42 \mathrm{~B}$.) which lead to the central cylinder through the adjacent aqueous tissue.

The anatomy of the wood has been described by GERnET and GheorghiefF. 
Halocnemum strobilaceum (Pall.) M. B.

A stumpy, often decumbent shrub which grows on clayey soil rich in salts.

The year-shoot has a thick bark containing aqueous tissue and green tissue, and is covered with opposite, reduced leaves, united in pairs to form a sheath. Almost every axil on a year-shoot is occupied by a branch or short-shoot shaped like a more or less elongated bud or a short catkin. An illustration of a branch is given by VoLKens in Nat. Pflanzenfamilien III (Chenopodiaceae) fig. 35. In fig. 43 is

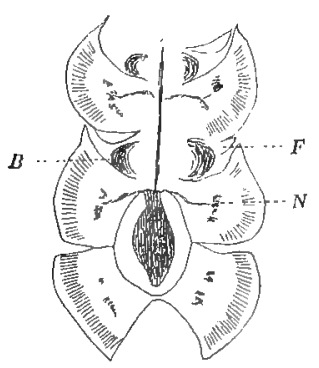

Fig. 43. Halocnemum strobilaceum. Longitudinal section through part of a short-shoot: $A$, Base of a lateral shoot which projects forwards (towards the reader); $B$, Bud; $F$, Base of a leaf; $N$, Vein ; the short line-shading indicates palisade tissue. $\times 12$.

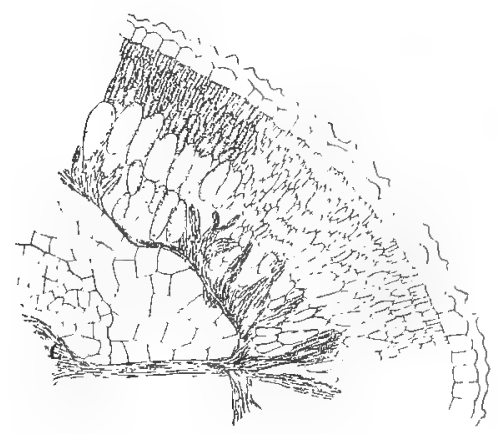

Fig. 44. Halocnemum strobilaceum. Part of a transverse section of an internode. A vein from the central cylinder $(C)$ branches out in the inner green tissue. In part of the green tissue the number of chlorophyll-grains is indicated. $\times 71$. (Slightly diagrammatic).

represented a longitudinal section of part of such a shortshoot. As stated by Warming (1897, p. 206), the leaves are somewhat peltate. Sometimes they support three buds (B. fig. 43), which are presumably flower-buds as the leaves on many short-shoots each subtend a triplet of flowers in the autumn. The flowering short-shoots die after the ripening of the fruits, and along with the distal part of the year-shoot drop off before the next vegetative period.

Beyond the dead short-shoots, new shoots are formed next year, often several together, either elongated year-shoots or new short-shoots.

The anatomy of the leaf has been described by WARMING 
(1897, p. 206). Transcaspian specimens correspond with his description, but I have not found stone-cells in the basal part of the leaf, nor the layer of short subepidermal cells recorded by Warming. In the leaf, as in the bark of young stem-internodes (fig. 44), there are three (or four) layers of small palisade cells which inwards are abruptly replaced by larger ones containing only a few chlorophyll grains. These adjoin a system of veins which branch out in great numbers through a certain zone of the bark or the mesophyll, and only within this zone is there a perfectly translucent aqueous tissue; this last is divided into two parts, an outer zone of large cells, and an inner zone of smaller cells.

The epidermis is thick and papillose, and the stomata are sunk.

\section{Suæda microphylla Pall.}

This species is known to me only from descriptions and herbarium material. Perhaps it should be considered as a chamaephyte as the stem is said to be decumbent. The stem may attain a thickness of 4 centimetres. The branches are long and widely spread out. The year-shoots are branched both in the inflorescence and in the vegetative portion, sometimes twice branched.

The leaves are typical Suceda-leaves, rather short. The plant flowers in July and the fruit is ripe in October.

Suæda physophora Pall.

This plant is said to be a shrub about one metre high, but I have not seen it.

\section{Lycium ruthenicum Murr.}

A shrub from 10 to about 60 centimetres high, spiny and with outspread branches. It is a salt-bush not generally found on sand.

Under specially favourable circumstances the year-shoots may attain a length of more than 60 centimetres, but as a 
rule they do not exceed 30 centimetres. They have a white bark, and are usually branched, branch-thorns arising in the leaf-axils; the leaf-base is thick and persistent. The branchthorns are generally short, about 1 centimetre long, and often bear only two leaves placed low down near the base. The branch-thorns may, however, become longer and bear several pairs of leaves. The flowers arise from the base of the branch-thorns either in the axils of the two low-set leaves, or next year they form part of the rosette-shoots which appear in the axils of these leaves. On long branch-thorns the flowers may also arise higher up.

The year-shoots generally terminate in a thorn; their distal part always seems to die away.

They flower during summer.

The leaf is isolateral in structure. There are stomata on both sides, generally flush with the surface but some of them are slightly raised and below them is a group of cells, $2-4$ on each side, which are round and devoid of chlorophyll; throughout the rest of the leaf these cells are wanting (fig. 45). The palisade tissue is $2-3$ cells

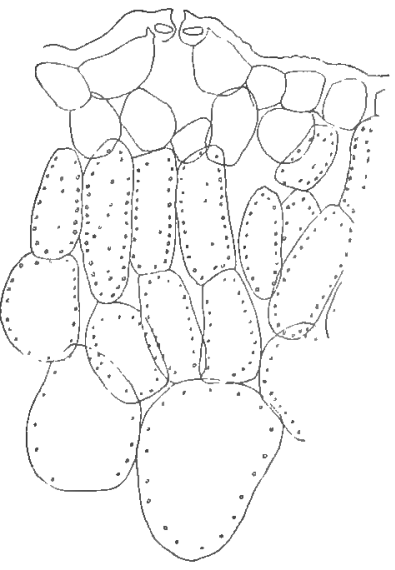

Fig. 45. Lycium ruthenicum. Part of leaf in transverse section. $\times 203$. thick, and towards the interior it merges gradually into a large-celled aqueous tissue containing a slight amount of chlorophyll. The veins which lie a little nearer the upper side than the lower, have bundles of bast on both sides and here are found a few perfectly translucent cells.

\section{Nitraria Schoberi L.}

A shrub, barely one metre high which prefers the claydesert. The bark is white, the leaves are thick and spathulate with short hairs, and are placed $2-4$ together on a small cushion, with small scales between them. The leaves 
and the scales surround a bud. According to Velenowsky (1907 p. 501) this has the following significance:

Nitraria has a pinnate leaf (or bipinnate) the petioles of which are reduced so that the leaflets are placed beside each other, and the scales between them are then partly stipular scales partly rudiments of leaflets. The bud between these leaflets is thus in reality the axillary bud of the leaf. This may during the same year give rise to a short-shoot which forms several of these whorls of leaflets one above another so that a leaf-rosette is developed - this is thick at the base and may have as many as 20 leaves (leaflets). Besides these year-shoot branches, shorter thorn-branches may occur. The year-shoot itself terminates in a branched inflorescence which of course dies after the fruit is ripe, or it ends as a thorn.

Normal buds which have not formed a rosette during the first year, seem next year only to be able to form either rosettes or vegetalive long-shoots, whereas the rosettes developed during the first year may give rise to both vegetative and floral long-shoots.

The plant flowers in May or June. The fruit is a black berry which is eaten by the natives.

The anatomy of the leaf has been described by B. Jönsson (p. 26, tab. III), whose observations are confirmed by my own. The leaf is isolateral with sunk stomata on both sides, and 2--3 layers of palisade cells the inner ones being larger and less green. Amongst the palisade are large mucilagecells. Like Jönsson I have found no tannic acid. - Compare also Volikens (table XI) illustrations of the structure of Nitraria retusa.

Jönsson also describes the anatomy of the stem and the bark, the latter with mucilaginous cork.

Reaumuria oxiana (Ldb.) Bois.

A much-branched dwarf shrub about 30 centimetres high, which prefers a firm soil, clay or stone. The stem is crooked and bent. The non-branching year-shoots may attain a length of about 15 centimetres, but only a portion of this 
survives till the next vegetative period. The bark of the persistent part is brown.

The leaves are $2-4$ centimetres long, linear-lanceolate. They are grey with salt-excretions which take the form of small white spots over depressions at the bottom of which the secreting glands are found. The structure of these (fig. $46 \mathrm{~B}$ ) is very similar to that of the glands figured by Volkens (tab. V) from $R$. hirtella. Volkens was of opinion that during the night the excreted salts absorbed water from the atmosphere (dew), which might then be absorbed by the

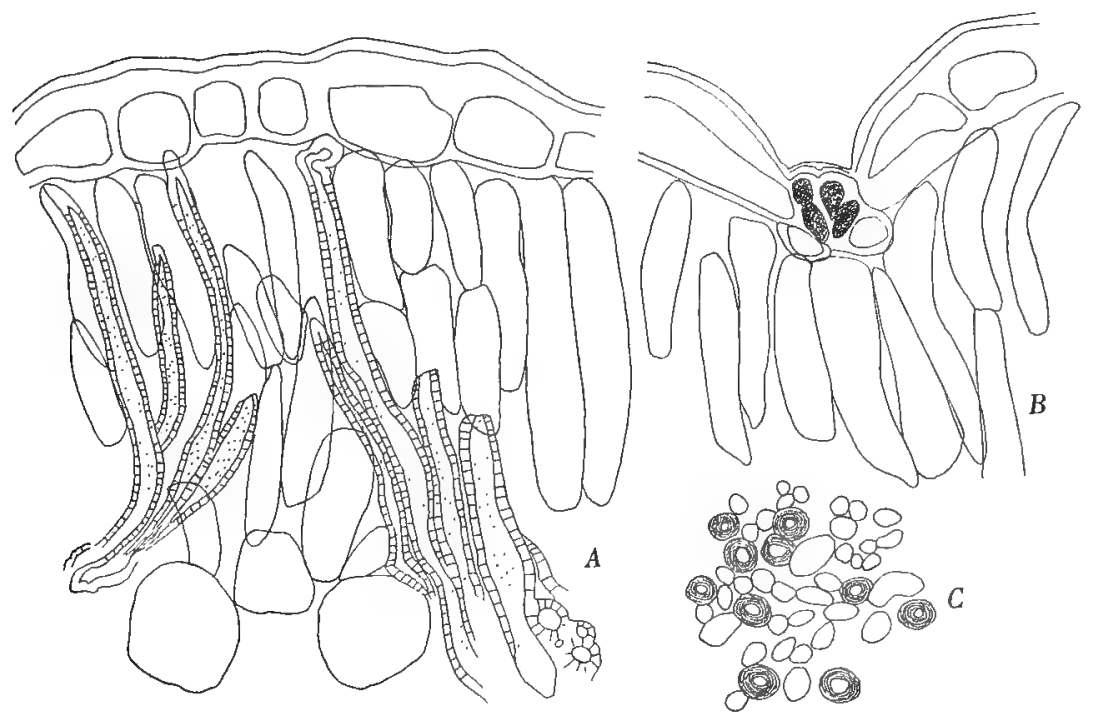

Fig. 46. Reaumuria oxiana. $A$ and $B$ parts of leaf in transverse section; in $A$ sclerenchyma-cells are seen; $B$, a salt-gland. $\times 202$. $C$, Surface section of palisade tissue, showing palisade-cells and sclerenchyma-cells intermingled.

gland and thus be utilised by the plant. Marloth (1887 p. 321) denies this and states that it is impossible for the glands of the leaf to absorb water from the surface without at the same time absorbing the salts. On the contrary the salt solution on the surface must absorb water from the gland, and according to Fitring this is what takes place (1. c. p. 267 note). And still more important, Fitring has arrived at the result that plants in the desert store salt 
internally up to a certain specific maximum varying for different species, and that in this physiologically determined limitation of salt storage they have a sufficient means for securing the high osmotic pressure which Fitring has pointed out in the desert-plants and which enables them to obtain water from the soil. In addition to sodium chloride, there is also excretion of carbonate of lime often in great quantities, so it is not at all certain that the excretion of sodium chloride is of any special importance. And finally Fitring points out that dew is exceedingly rare in the Sahara.

The flowers of Reaumuria are large and terminal on the branches, they appear in July. Below the calyx there are several bracteoles forming an involucre. The fruit is a capsule with about a score of white woolly seeds.

The leaf anatomy of Reaumuria oxiana has been briefly described by Vesoue. The thick epidermis consists of one layer, and the stomata and salt-glands are depressed. The leaf is isolateral with about two layers of palisade cells and a central water-storing tissue. Between the green tissue and the water-storing tissue, or amongst the palisade, are numerous bands of sclerenchyma running longitudinally within the leaf, and from these issue long, thin sclerenchyma-cells which as idioblasts stretch through the palisade to the epidermis as if to support it from the inside (fig. $46 \mathrm{~A} \mathrm{C}$; also Vesque tab. 8, fig. 7).

\section{Reaumuria fruticosa Bge.}

On moderately stable sandy soil I have found shrubs of this species scarcely attaining the height of one metre.

It is strongly branched, the branches being strikingly thick and light in colour. The year-shoots may attain a length of 5 centimetres, and apparently always die back at the apex, which remains as a dry stick. Branches of two different kinds occur on the year-shoot, some are short but quite evidently branches with elongated internodes, others are rosette-like short-shoots. The former may be wanting, but when present they are generally placed towards the apex of the year-shoot. They are rarely 2 centimetres long, gener- 
ally less than $1 \mathrm{~cm}$., and bear leaves like the year-shoot. The leaves are small about $2 \mathrm{~mm}$. long, but comparatively broad and flat and besprinkled with salt-grains. The rosette shorl-shoots are found in every axil except occasionally the ones which bear the branches with extended internodes. They carry about 12 leaves, shorter, thicker and more persistent than the subtending leaves. Rosette-shoots are also formed on old year-shoots, and altogether they are the most important assimilating organs of the plant.

I have not seen the flower.

The anatomy of the leaves is similar to that of $R$. oxiana and $R$. hirtella (Volkens), and also discussed by Vesque, but his statements do not quite agree with what I have found; for instance he finds no mechanical tissue. - The epidermis is very thick and the epidermal cells are almost filled with mucilage from the outer wall. Sunk stomata and salt-glands occur, the latter being similar in structure to those of the preceeding species. There are two or more layers of palisade cells extending all the way round, and starch-sheaths enclose the veins. Large bands of sclerenchyma are present, irregularly arranged, but I have not found idioblasts between the palisade cells.

\section{Tamarix.}

Fifteen species of this genus have been recorded for Turkestan. They only thrive as a rule in places which are not too dry. On river-banks they are very abundant and Antonow says (see above p. 33) that Tamarisk in the desert is a sign of water not far off. In the sand-desert they are able to some extent to hold their own against the sand (comp. above p. 127-128) and where they are present water is presumably not very far down. They have long, vertical and obliquely descending roots. Under favourable conditions they are trees with thick foliage, but are only small shrubs under unfavourable conditions.

The leaves of Tamarisks, as is well known, are small green scales. The plant does not shed its leaves but the branches which bear the leaves, except in the case of per- 
sistent branches where only the leaves are cast. They thus have assimilating shoots which biologically play the part of leaves. In many (perhaps all) species the leaves are coated

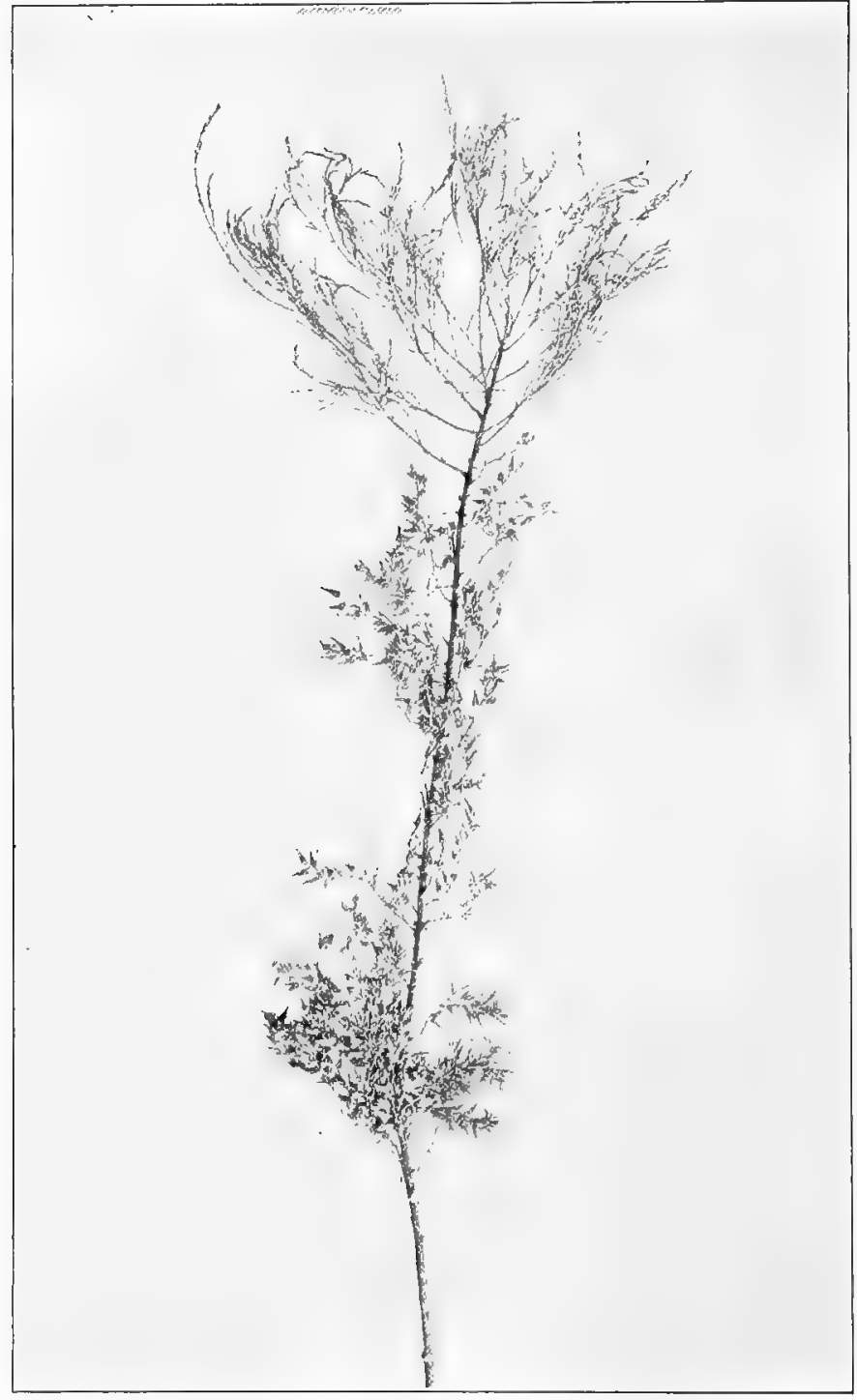

Fig. 47. Tamarix laxa. Last year's year-shoot with floral (fruit-bearing) shoots at the base, vegetative shoots at the top. May. 
with salt-concretions; especially is this the case with $T$. hispida and T. Karelini, where these are very numerous.

As regards the development of vegetgative and floral branches, the species of Tamarix may be divided into two groups. In the first group the floral shoots appear on the year-shoot of last year while the present year-shoot is purely vegetative. This group includes Tamarix laxa, Meyeri, Androssowii, florida, elongata, polystachya. This characleristic is shown in $T$. laxa (fig. 47). The vegetative and floral shoots are, however, not always separated as in this case, but may be intermingled. A single one or several of the vegetative shoots seen in fig. 47 will become rejuvenescence shoots, the remainder are short-lived assimilating shoots. All the vegetative shoots, as will be noticed, are many times branched. The species of this group flower early, during April and May, and according to Bunge (1852 p. 8) they have as a rule tetramerous flowers.

The species of the second group bear the flowers at the apex of the present year-shoot which has vegetative branches at its base. To this group belong T. Pallasii, hispida, Karelini, arceuthoides, Ewersmannii, karakalensis, Korolkowii, leptostachya and pycnocarpa.

The branch of $T$. hispida illustrated in fig. 48 is the shoot of this year. All the lower branches of primary order bear much-branched vegetative shoots at the base and inflorescences at the top, or they are purely vegetative. The upper year-shoot branches are entirely floral.

The species included here are said by Bunge (l. c.) to have as a rule pentamerous flowers which open late, from July to September. As the flowers arise on the outmost part of the year-shoot and its branches, they cannot appear until these axes have attained a certain stage of development.

In this group as in the first, the flower axes and the greater part of the vegetative branches fall off, and only a single one or a few become rejuvenating shoots.

Short-lived vegetative branches may appear in all the species on old year-shoots in the axils of leaves which have fallen off. They may bear inflorescences as in the species of the second group. 
All the Tamarisks have small red or white flowers arranged in racemes. The fruit is a small capsule with woolly seeds easily transported by the wind.

The anatomical structure of the leaf I have examined

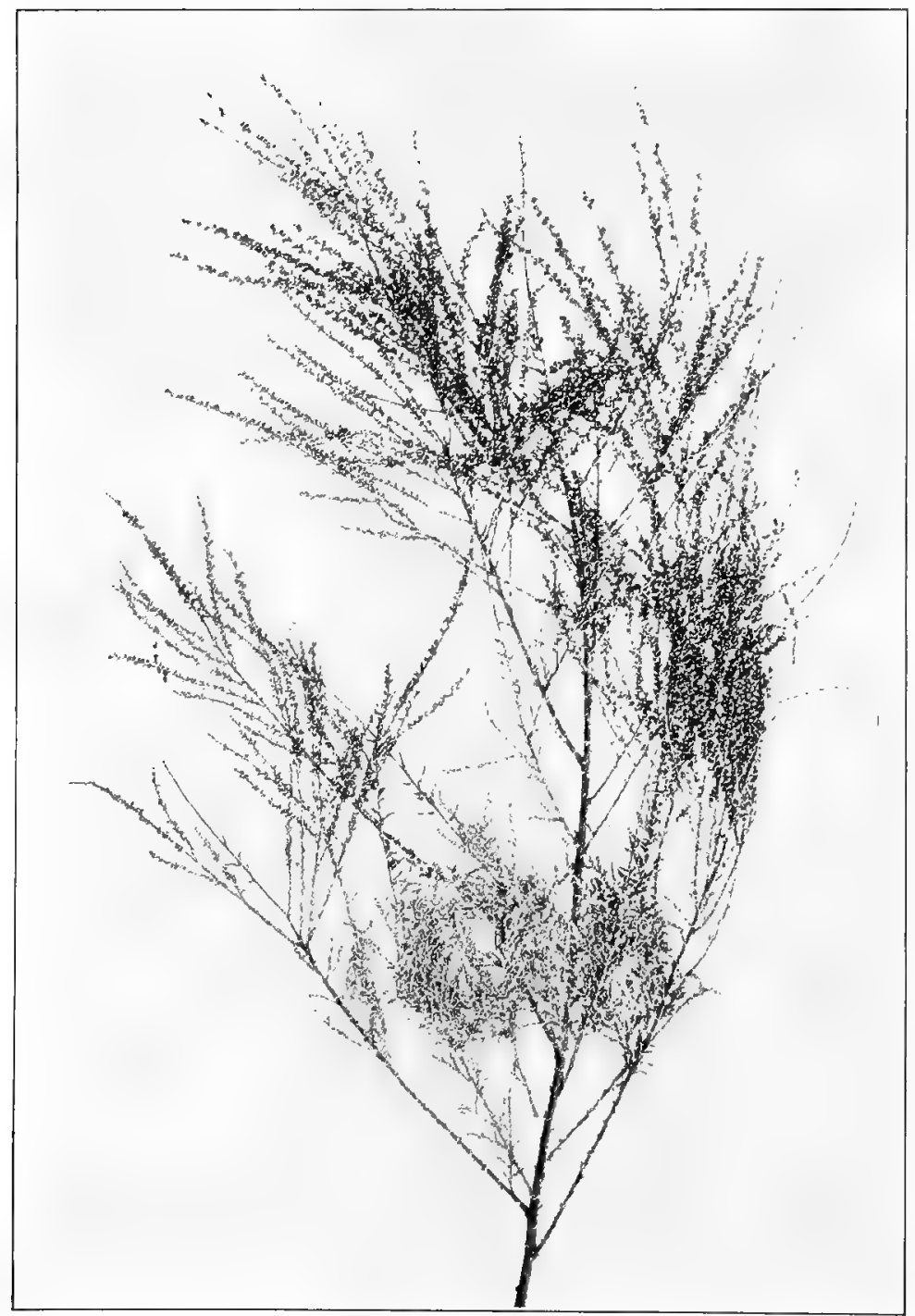

Fig. 48. Tamarix hispida. Year-shoot with flowering branclues at the top, vegetative at the base. August. 
in $T$. hispida. All the cells of the single-layered epidermis are distinctly convex and papilla-like. The stomata on the upper and lower surfaces, and the salt-glands are sunk. One layer of palisade cells all round is present both in the leaves and the assimilating branches. The leaf also has rather open spongy parenchyma and veins with a bast-sheath besides storage-tracheids ("Speichertracheïden").

I have not investigated in detail the more mesophytic fanerophytes (Elaeagnus, Ulmus, Morus, Populus, Salix). Elaeagnus hortensis was observed in August with two series of branches on the year-shoot, but this does not appear to be the rule. The same holds good with regard to Salix angustifolia. The species of all the genera just mentioned flower in spring.

The above Fanerophytes have the following characteristics common to all or some of them.

The leaves are greatly reduced. In one set of species they take no part as assimilating organs (Eremosparton, Calligonum, Ephedra, Haloxylon, Halostachys, Halocnemum), while in others they are scale-like, but green (Tamarix, Reaumuria fruticosa). Astragalus has leaves which are wholly or partly shed during summer, but whether as in the case of Spartium junceum (according to BERGEN), there is no assimilation or at any rate very little after the leaves are shed, I cannot say, and one can scarcely draw a conclusion from a single case. Ammodendron, Halimodendron and Smirnowia have persistent, small, hairy leaves, while Prosopis, Atraphaxis, Lycium, Nitraria and Reaumuria oxiana have persistent small and glabrous leaves. The Salsola species have cylindrical persistent leaves.

The leaves in Salsola and the assimilating shoots in the leafless species are all centric in structure, the latter in most cases have abundant mechanical tissue.

In the flat-leaved species the leaves are without exception isolateral in structure.

The branches in most sand-desert species are slender, 
pliant and more or less pendulous; in clay-desert species on the contrary they are generally stiff and short.

The year-shoots are branched except in a very few cases (Halimodendron, Reaumuria oxiana). Branched year-shoots are thus the rule, and non-branching the exception. A similar case has, to my knowledge, never been pointed out for any community of Fanerophytes.

Warming $(1892$, pp. 408, 252) and after him Malme have drawn attention to a number of South American species with branched year-shoots. RACIBORSKI also gives illustrations of several species of this kind, but without recording this characteristic. These species are mostly forest-plants, but some belong to the Savannas (Malme). Malme regards the branched year-shoot as a primitive character in dicotyledonous trees, non-branching on the contrary being a secondary feature acquired in the course of time. However this condition in the case of the broad-leaved South American plants is of less interest to us than the branch system in other Fanerophytes poor in leaves or leafless. This condition is certainly worthy of special study although in the literature I have only found occasional references to it.

In many cases the year-shoot branches are annual assimilating shoots, more rarely they are continuation shoots which take part in the extension of branches. No definite limit can be drawn however between the two. The assimilating branches have been described in many of the species mentioned (e. g. Eremosparton, Calligonum, Tamarix, Astragalus, Salsola etc.); biologically they play the part of leaves. Assimilating branches in many species are not confined to the last year-shoot, but also occur on older branches. In such cases they arise on the exterior side of lateral branches, or where such ones have previously been, and often several together. Thus the characteristic tufts of branches originate, which likewise distinguish so many of the trees and shrubs of the desert; they have been described and illustrated in the case of several species (e. g. Eremosparton, Calligonum, Smirnowia). Similar conditions are also found in Spartium, Carmichaelia, and others.

A further characteristic of the year-shoots is, that they do not as a rule persist throughout their whole length, but 
the outer part dies, (probably killed by the heat and drought during the height of summer) and it remains next year as a dead stick, frequently as a thorn. One of the few exceptions to this rule is Halimodendron.

As regards the majority of the fanerophytic Chenopodiaceae and Lycium, flowering takes place in summer; $H a-$ loxylon and probably all the rest flower during spring, at the latest in June. All the late-flowering species with the exception of Lycium have small flowers which are completely enclosed up to the time of anthesis. The early flowering species include a large proportion of Leguminosae, and it seems to be the rule, or at any rate is frequently the case, that only the early flowers fructify while the later ones become dried up.

The fruits (or the seeds) are in most cases such as may

- - be easily transported by the wind; they are light and furnished with some kind of parachute, and as a rule they contain only one or a few seeds ${ }^{1}$ ). The open network on the fruit (fig. 28) of Calligonum, the large bladdery pod of Smirnowia and Halimodendron, the winged fruits of Salsola, Haloxylon, Ammodendron and Atraphaxis, the small light pods of Astragalus and Eremosparton, and the white woolly seeds of Reaumuria illustrate the different adaptations by which wind-transport is achieved.

Fruits with no special adaptation for flight are seen in the berries of Nitraria and the small nuts of Halostachys and Halimocnemis.

\section{B. Chamaephytes.}

As explained in chap. 12 (p. 173) these all belong to the xerophytic aspect, they are summer-plants and a great number of them are late flowering.

\section{Capparis spinosa $\mathrm{L}$.}

A decumbent undershrub found on clay soils and more especially on stony soil. The branches are long and bear

1) Comp. E. GaIN 1894: Moist soil produces many but small seeds, dry soils few seeds but large. 
broad, large leaves, bright green in colour and with two spinous stipules at the base. According to Volkens (p. 97), the leaves during summer acquire a coating of wax so that they lose the bright green colour. I have not observed this, but it may also take place in Transcaspia since my opportunities for observing Capparis spinosa in summer were few. The year-shoots are branched The lower part only is persistent and lignified, and it gradually increases in thickness. The beautiful large white flowers are placed singly in the leaf-axils; flowering begins in May and continues well into July, perhaps longer. The fruit is a stout berry.

The anatomy of the leaf has been illustrated by Volkens (tab. IX, tigures 1-2), and my Transcaspian material shows the same structure. Some of the epidermal cells, however, have a thickened inner wall (mucilage?) and I have not observed that the palisade cells are arranged in groups round the large thick-walled tracheids ("Speichertracheïden"). The leaf is isolateral, with mesophyll consisting almost exclusively of palisade cells. The stomata are slightly sunk.

Hulthemia (Rosa) berberifolia Dum.

This species is likewise a clay soil plant with decumbent shoots and broad leaves. The latter are dentate, hairy, elliptical or spathulate, about 1 centimetre or rather more in length, and closely set because the internodes are shorter than the leaves, sometimes so short as to produce rosettes on short-shoots. The stem bears many strong curved white prickles as well as others which are thin and subulate. I have only seen the plant in May when it carries large, handsome, yellow flowers. The distal parts of the yearshoots may die away, but whether this occurs always I cannot say. No material was available for anatomical investigation.

Haplophyllum obtusifolium Ldb.

This is a typical undershrub which occurs especially on stationary sand. It is strongly branched but according 
to Bunge (Rel. Lehm. p. 62) other forms occur in which the branching is only slight. The year-shools arising from the persistent parts may be branched, but generally this does not seem to be the case. They are numerous and slender, and bear small, lanceolate leaves which attain a length of $1-2$ centimetres, bright green in colour and containing many lysigenous oil-reservoirs.

The yellow flowers appear in July or August. The fruit has few loculi and a few seeds in each loculus.

The leaf is isolateral in structure. The epidermis consists of one layer with a thick outer wall and the stomata slightly sunk. There are about three layers of palisade cells on each side and a narrow middle zone of rounded cells. This zone includes many tracheids ("Speichertracheïden") besides the veins which both above and below have a sheath of rather thin-walled, non-lignified bast. There are many lysigenous oil-reservoirs measuring in diameter more than half the thickness of the leaf.

The green cortex has a thick-walled epidermis of two layers overlying 3 or 4 layers of short palisade cells limited towards the interior by a layer of thin-walled, tangentially extended cells which may be regarded as collecting sheath. Many bundles of bast occur in the inner cortex.

Stellera Lessertii (Wickstr.) C. A. M.

An undershrub 20-50 centimetres in height and occurring in the clay-desert. It is much branched and numerous dead branches are found; whole branch-systems may die off leaving short dry sticks projecting in all directions. New branches are formed from branches of the previous shootgeneration and also from old branches. The year-shoots bear branches the same year, often $2-3$; these are unbranched, with long internodes, and they all terminate - if sulficiently long lived - in an inflorescence. This is a short, simple spike, and the small yellow flowers appear in July. The fruit is a pear-shaped nut about $4 \mathrm{~mm}$. long, it is surrounded by the lower strongly woolly-haired part of the perianth.

The leaf is hairy, narrow and small, almost elliptical- 
lanceolate and directed obliquely or vertically upwards. Its structure is isolateral (fig. 49). The epidermis is thick and most of its cells on both surfaces have a thick mucilaginous inner wall which in transverse section presents a characteristic appearance, two light stripes showing between the green tissue and the cell cavities of the epidermis. These cavities are filled with tannic acid and the contents are therefore dark.

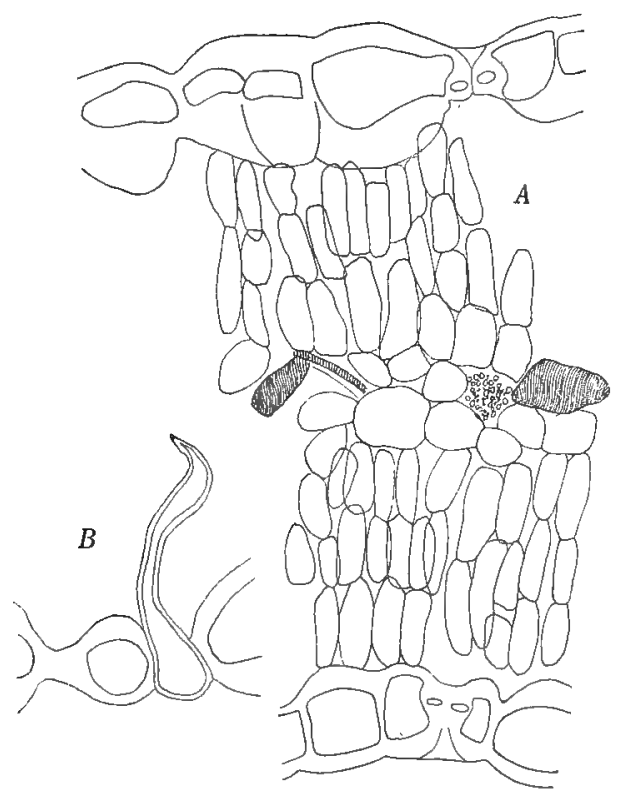

Fig. 49. Stellera Lessertii. A, Leaf in transverse section. $B$, a hair. $\times 203$.

There are stomata on both surfaces. The palisade cells occur in 2 or 3 layers above and below; the centre is occupied by the veins which take up most of the space; between them there are 2 or 3 layers of rounded cells less rich in chlorophyll, and many "Speichertracheïden" (shaded in fig. 49).

A young stem shows a thick but non-mucilaginous epidermis with stomata which are not sunk; below this are 3 layers of rounded green-cells of which the outer ones are slightly palisade-like. These are followed by about two layers of round or tangentially extended cells containing a small 
amount of chlorophyll. The inner cortex consists of large groups of sclerenchyma separated by narrow bands of translucent cells. The cortex of the youngest branches is green, but when the epidermis becomes filled with tannin the branch assumes a dark-brown surface which ultimately is ruptured by cork-formation.

\section{Alhagi Camelorum Fisch.}

One of the most common plants in Trancaspia. It looks like a stumpy shrub with green branches. The aerial parts, however, are not persistent and in general Alhagi is doubtless a root-geophyte. But as short stems are occasionally found - probably rhizomes originally - from which new shoots rise 10-30 centimetres above the ground, and as the determination of RAUnkirer's biological types is dependent on the position of the least protected buds, I propose to classify the species under the chamaephytes.

The light-shoot of Alhagi is green and spiny. The plant frequently assumes the globular form since the close-set expanded branches project equally in all directions. The leaves are small, at most a couple of centimetres long, oblong-ovate or spathulate, and the majority fall off during the early part of summer. This is especially the case with the leaves developed later, whereas many of the older, lower leaves persist for a long time. This is probably due to the great heat and dryness of the summer which prevents the perfect development of new leaves.

All the leaf-axils except the very uppermost bear thornbranches. These are leafless and green, about 4 centimetres long and with a yellow tip; only the upper thorn-branches bear flowers. These branches arise not in the middle of the leaf-axil but obliquely lowards the cathodic side of the leaf (the phyllotaxy is a $\% / 5$ spiral). Many of the leaf-axils of the main-shoot give rise to long-shoots beside the spine, on the anodic side; these long-shoots bear leaves which also subtend spines except sometimes the upper ones, more rarely they bear long-shoots.

Alhagi has horizontal roots which at inlervals send out 
light-shoots directed upwards. Normally these die during winter down to the surface of the soil and new shoots appear next year from the upper part of the subterranean perennial

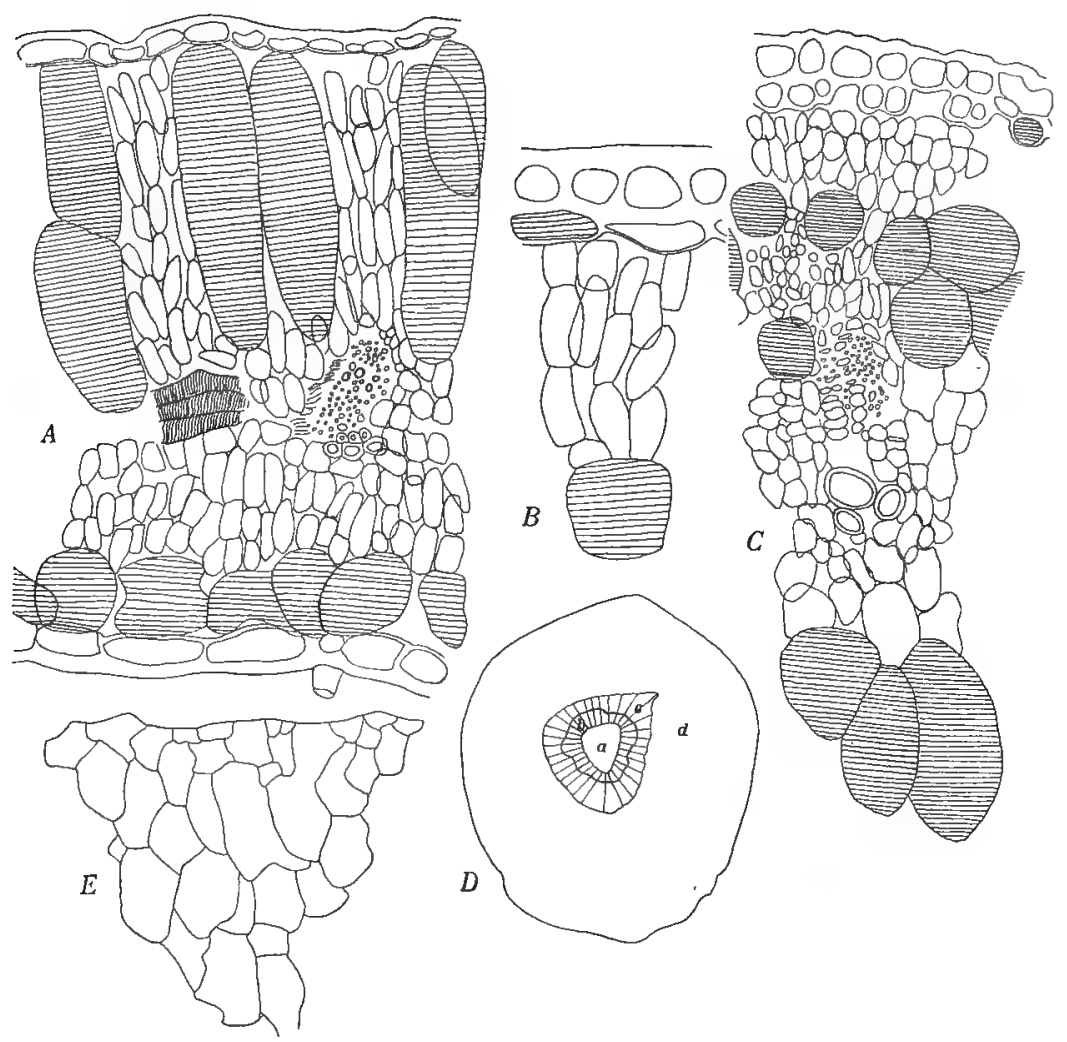

Fig. 50. Alhagi Camelorum. A, Leaf in transverse section. B, Part of a transverse section of the outer cortex of a thorm shoot. $C$, Part of transverse section of a young shoot. $D$, Transverse section of a sandshoot (rejuvenescence-shoot); $a$, pith; $b$, wood; $c$, inner cortex; $d$, outer cortex (cork). $E$, The outermost part of the outer cortex in $D$. $D$ : slightly magnified; the others. $\times 203$. Cells containing tannin are hatched.

rhizome. These as well as old roots (?) may become very thick; I have seen them $4^{1 / 3}$ centimetres in diameter.

From what has been already said, it will be understood that the Alhagi are gregarious plants, and that their subterranean parts contain food-reserves which enable them to contend against very unfavourable conditions. Alhagi has 
been frequently mentioned in the preceeding pages (e. g. pp. $122,128)$.

When buried by the sand axillary shoots encased in a thick corky coating (see below) grow upwards through the sand to the surface (comp. fig. 22 which shows a somewhat similar case in Heliotropium). Specimens of Alhagi were found where this had taken place twice: The first restoration shoot had after burial formed a new shoot. On the other hand rhizomes or roots laid bare by the sand being blown away from them may form new light-shoots.

The red flowers of Alhagi appear in isolated groups 2-7 together on the upper spines, they commence to expand in June. The fruit is an jointed crooked pod, (not a lomentum) with 5--8 joints and as many seeds; it is very light.

The anatomy of Alhagi has been examined among others by B. Jönsson who gives a number of somewhat diagrammatic figures.

The structure of the leaf in my Transcaspian specimens agrees with his description and figures. The hypoderm containing tannic acid on the lower surface, (see fig. 50, A) may, however, be wanting. When present it is seen in sections parallel to the surface to form a net-work below the epidermis. The stomata are slightly sunk, the epidermis is one-layered and there are $4-5$ layers of short palisade cells on the upper and lower sides.

As most of the leaves fall off early, the branches are well provided with assimilating tissue (fig. $50 \mathrm{~B}$ and $\mathrm{C}$ ). The epidermis consists of two layers, and many of the cells of the inner layer contain tannic acid; the palisades are nearly similar to those of the leaf and are apparently best developed in the thorn-branches (fig. $50 \mathrm{~B}$ ).

Within the green tissue there lies a parenchyma with many large cells containing tannic acid. In older branches the leptome has bands of sclerenchyma on the outer side. The pith is large-celled, many of its cells containing tannin. The presence of tannin in fig. 50 is indicated by hatching. Reference should also be made to Schube, B. Jönsson and Volkens; the latter (tab. III, fig. 10) gives a transverse section of an internode of Alhagi manniferum. 
A restoration-shoot grown up through the sand from a buried shrub of Alhagi had its subterranean part beset with scale-leaves and with a yellow coating which was thick and spongy to the touch. When cut through the coating proved to be a thick layer of cork (fig. 50, D, E), formed from a phellogen in the cortex; this was double the thickness of pith, wood and inner cortex together. All the cells had exceedingly thin corky walls, easily torn and all empty and dead. Inside such an air-filled case the growing shoot must be well protected.

Heliotropium dasycarpum Ldb.

An undershrub occurring in the clay-desert. It has leaves 1 to 2 centimetres in length, coated with stiff hairs; the foliage is so open that the whole plant is transparent. The flowers appear in June and July and evidently only the lower flowers of the scorpioid cyme produce fruit. The achenes are long-haired and hard-shelled.

The leaf is almost isolateral in structure. The epidermis is one-layered with stomata on both surfaces and not sunk. Both surfaces are coated with hairs most of which are bent to one side while some are short and somewhat dome-shaped. The cuticle extends over all the epidermis as a warty covering. The hairs arise from large thin-walled epidermal cells which contain stratified cystoliths, the so-called haircystoliths (see Solereder 1899, p. 632, fig. 127; the hairs mentioned here are similar to fig. B). The upper face of the leaf has one layer of long palisade cells, the lower face two layers of shorter ones. Grouped around the veins in the middle are some isodiametric or slightly oblong cells, translucent or containing a little chlorophyll.

Frankenia hirsuta L. (= F hispida D. C).

This species occurs in comparatively moist localities and as a rule on a saline soil. It has decumbent, lignified branches. The leaves are about half a centimetre long, revolute, with scattered hairs and with grains of salt. The small red flowers may be found still open in July. 
The structure of the leaf is dorsiventral (fig. 51), but the stomata and salt-secreting glands are found on both surfaces, whereas the setaceous hairs are absent on the upper side. There are long palisade cells on the upper side, generally transversely divided, and short palisades on the lower side

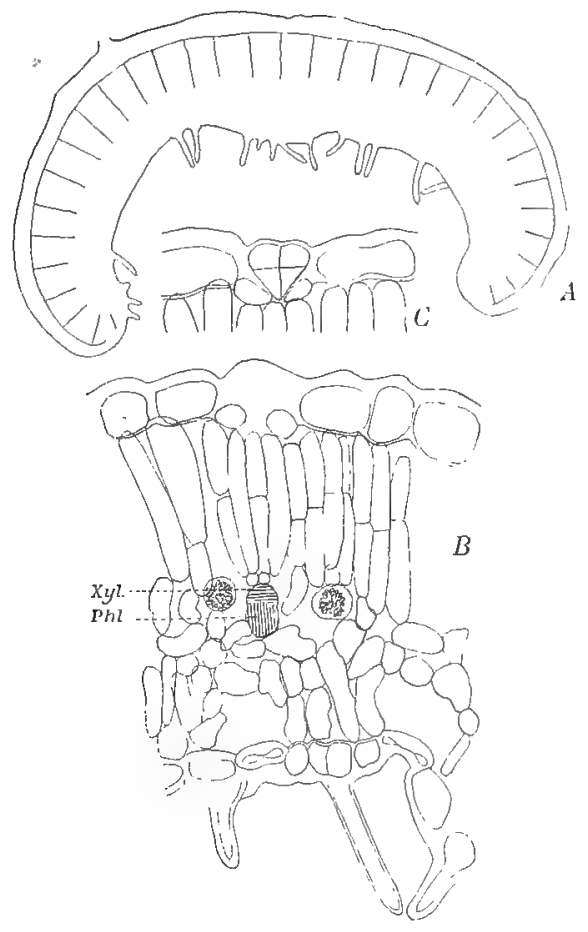

Fig. 51. Frankenia hirsuta. A, Outline of leaf in transverse section with epidermis, palisade cells and hairs indicated. $B$, Part of leaf in transverse section. Xyl., Xylem; Phl., Phloëm. C: Gland. $A: \times 47 ; B, C: \times 203$.

and a loose spongy parenchyma with crystal-cells in the middle. The air-spaces in the interior of the leaf are generally fairly large. Sclerenchyma is wanting.

Convolvulus eremophilus Bois. \& Buhse.

An undershrub growing on clay or stationary sand. The year-shoots arising from the perennial branches are branched 
two or three times. The tertiary series of branches and the upper ones of secondary order are apparently always short (up to about 4 centimetres) and rarely have more than 2 or 3 internodes. It seems as if growth were interrupted by the drying up of the terminal bud. Each of these small branches bears one or two flowers.

The lower leaves are lanceolate-linear and may attain a length of about 3 centimetres; the upper "ones are small scales, so that the plant is thus practically leafless. All the green parts are covered with slanting bipartite hairs similar in form to those of C. erinaceus (see fig. 53).

The white flowers open in June. The capsule contains two large, long-haired and hard-shelled seeds.

I had no opportunity of examining the anatomy of the leaf. The primary cortex resembles that of the next species. The epidermis consists of one layer and contains tannic acid; the stomata are not sunk. There are three layers of palisade cells which towards the interior are supported by one or a few layers of tangentially extended cells, almost devoid of chlorophyll, and among these are a few bast cells opposite the groups of phloëm.

Convolvulus divaricatus Rgl. \& Schm.

An undershrub which grows on stationary sand. The year-shoots, about 30-40 centimetres in length, are sinuous, white-woolly and two or three times branched. The leaves are small, (5 to $15 \mathrm{~mm}$. long) and with a broad cordate base.

The isolated white flowers open in May.

The structure of the leaf is isolateral. About five layers of palisade cells occur, the middle ones being the smaller. The epidermis is one-layered and contains tannic acid. Both surfaces are covered with long projecting hairs which are bipartite but one arm is much reduced. Alongside the veins there are secreting cells (laticiferous cells). The structure of the green cortex of the young branches is similar to that of the previous species, but the hairs are erect and the coating is much denser. 
Convolvulus crinaceus Ldb.

An undershrub with very long roots and preferring somewhat stationary sancly soil. It attains a height of about

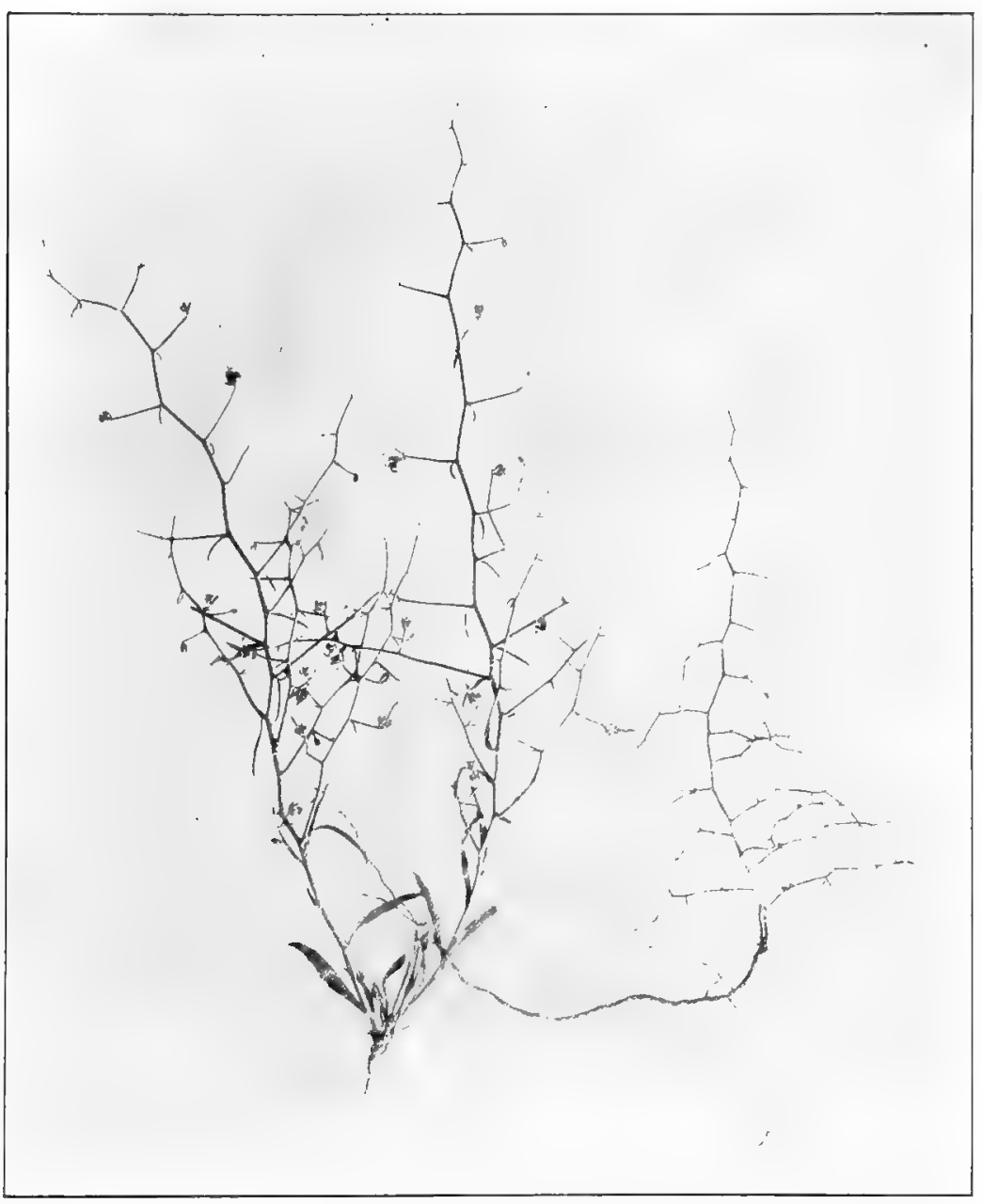

Fig. 52. Convolvulus erinaceus. To the left a leaf-bearing plant (June). To the right a specimen which has shed its leaves. (July).

40 centimetres, but according to Aitchison it may reach the height of 1 metre ( $2-3$ feet). The year-shoots are stiff, strongly branched, geniculate at the nodes and the branches 
are spread out or reflexed. In spring and early summer the plant developes leaves (see fig. 52) which are linear-lanceolate, 2-3 centimetres long, and white-haired, but the leaves fall off later in the summer so that the branches become the only assimilating organs. In late summer the larger plants are leafless, globular and spiny shrubs. The spines are formed by the year-shoot branches of secondary and tertiary
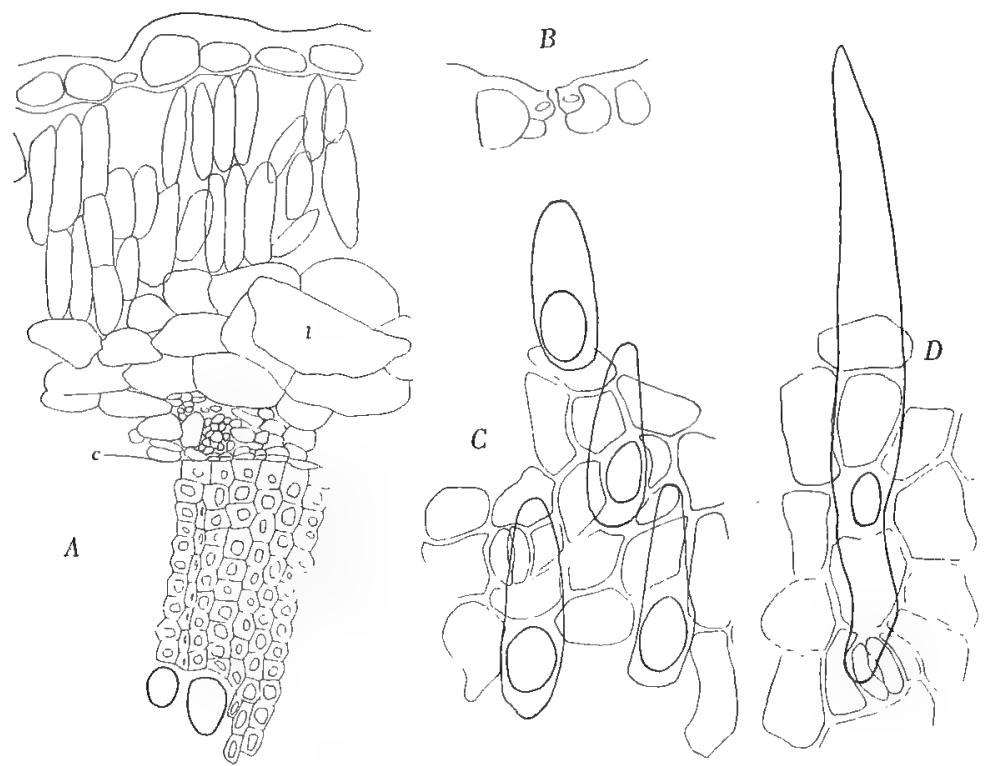

Fig. 53. Convolvulus erinaceus. A, Transverse section of the green cortex and part of the wood; two vessels are represented; $c$, Cambium; $l$, Secreting cell. $B$, Stoma. $C$, Epidermis with hairs, seen from above. $D$, A similar view of Convolvulus fruticosus. ( $X$ 203).

order, and also by the uppermost ones of primary order which as a rule have formed only one internode and the beginning of a second one when growth ceases, hence the branch remains as a spine, terminated by a dead, withered point.

The white flowers occur singly on these small branches, and open in June and July. Aitchison says that they open at sunrise, but I have found them open in the middle of the day in a broiling sun. 
The capsule often (always?) contains only one seed with short woolly hairs and a hard shell.

I have not examined the anatomy of the leaf. The primary cortex of the branches is similar to that of the two species of Convolvulus described above, as will be seen from fig. 53. The inner cortex, as in these species, includes secreting cells (fig. 53, A.1.), which as seen in longitudinal section stand in long rows like piles of barrels. (comp. Hallier). Similar cells are found in the pith which also encloses leptome tissue (a generic character).

\section{Convolvulus \\ fruticosus Pall.}

Grows on clayey or stony soil. An undershrub with stiff, spiny branches. The yearshoots issuing from the low knotted perennial parts are branched once, twice or three times. The branches, more especially the ones of secondary order, are spread out or bent backwards; the branches of tertiary order and also the upper ones of secondary order are spines, of which the lower ones bear flowers. Each bears

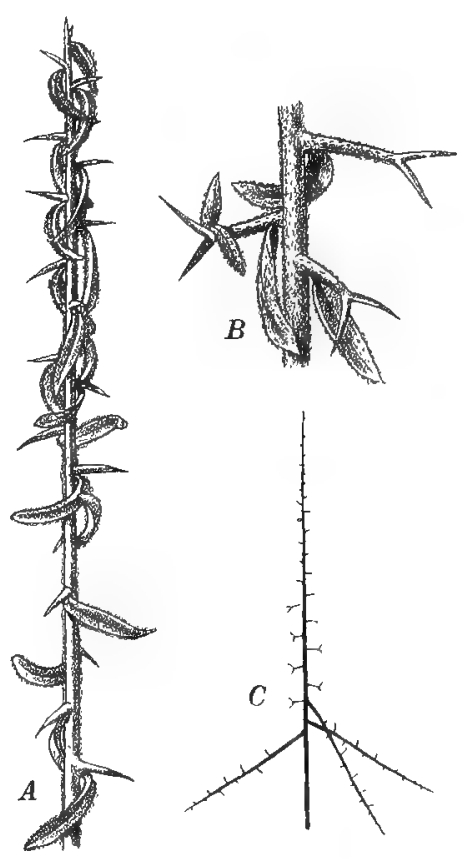

Fig. 54. Convolvulus fruticosus. Upper $(A)$ and middle part $(B)$ of a shoot. $C$ : Scheme of branched year-shoot. August.

only one terminal flower with small foliage-like prophylls each subtending a branch-spine which is generally leafless. After the flower and the two leaves have fallen off, a forkshaped spine remains behind. (fig. $54 \mathrm{~B}, \mathrm{C}$ ). The upper thorns are unbranched.

The leaves are small and lanceolate; the lower ones are the larger and may attain a length of about $2^{1 / 2}$ centimetres, while higher up they are shorter and narrower. In the 
month of July they all become bent vertically downwards and curl up into something like a spout. (fig. 54).

The plant flowers in May, the corolla being comparatively large, pink and coated with woolly hairs.

The young branches and also the leaves are white with a coating of bifurcate convolvulaceous hairs, the arms of which are very unequal in length (fig. 53, D). The longer arm is directed towards the apex of the organ.

The leaf is isolateral in structure. The outer wall of the epidermis is very thick, as thick as the cell cavity which contains tannic acid. The stomata are sunk. There are two or three layers of palisade cells above and below; strong bundles of bast surround the veins.

The outer cortex of the young branches has the same structure as half a leaf.

\section{Acanthophyllum elatius Bge.}

A plant of stony and clay soils. The woody base gives rise to numerous straight unbranched twigs about half a metre long, with white bark and bearing opposite stiff prickly leaves. Before the next vegetative period the branches have died off almost down to the ground. They bear small axillary leaf-rosettes, and the apex carries a cymose inflorescence.

In the middle of the leaf is found a thick band of sclerenchyma, many times thicker than the midvein which extends along its upper side. Laterally there are a couple of smaller veins partly accompanied by narrow bands of sclerenchyma on the leptome side. From the median strand palisade cells radiate in all directions. The epidermis has very thick outer walls. The stomata are not sunk. The intercellular spaces in the interior of the leaf are of considerable size (fig. 55, B).

Acanthophyllum pungens closely resembles the above species. As for the other species recorded, I have not examined them. 
Noaea spinosissima L.

An undershrub which prefers stony soils (on mountains). It is much branched and forms a thick, spiny, globular shrub; the branches die down almost to the ground and arise from a lower, lignified long-lived part. The leaves are

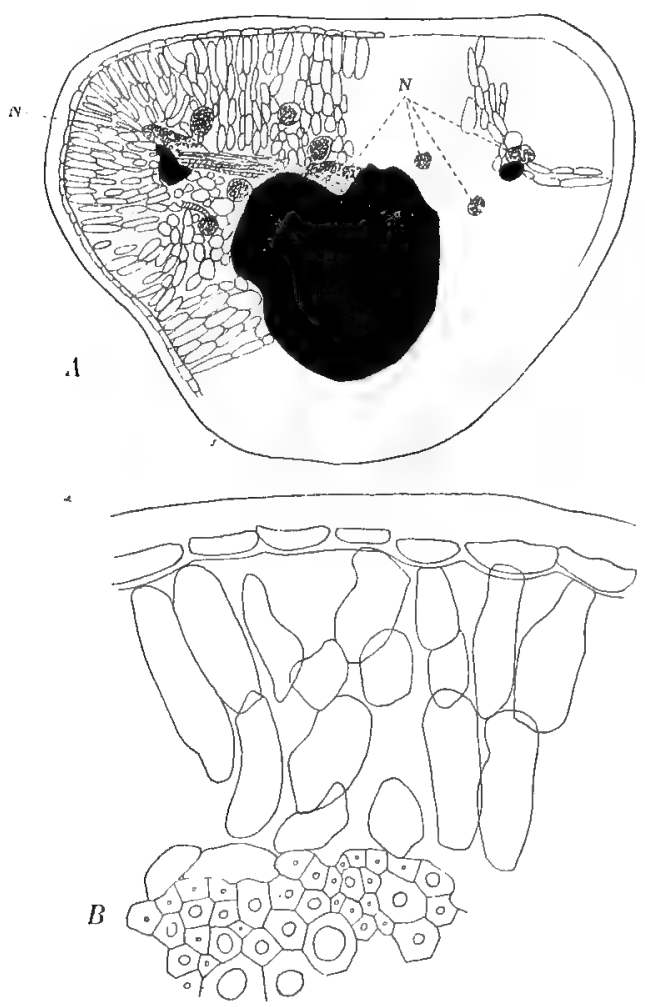

Fig. 55. Acanlhophyllum elatius. A, Leaf in tranverse section; Sclerenchyma in black; $N$, Veins. $B$, Tissues from the lower side of $A . A, \times 77 ; B, \times 203$.

long, triangular and pointed like a spine. They all subtend thorn-shoots which attain a length of $3-6$ centimetres and these in their turn frequently bear lateral thorn-shoots.

Flowering season October, the flowers being closely surrounded by bracteoles. The fruit is a nut enclosed in a winged perianth. 
Nanophytum erinaceum Pall.

My knowledge of this species is derived solely from herbarium specimens. It is almost a cushion-plant as the

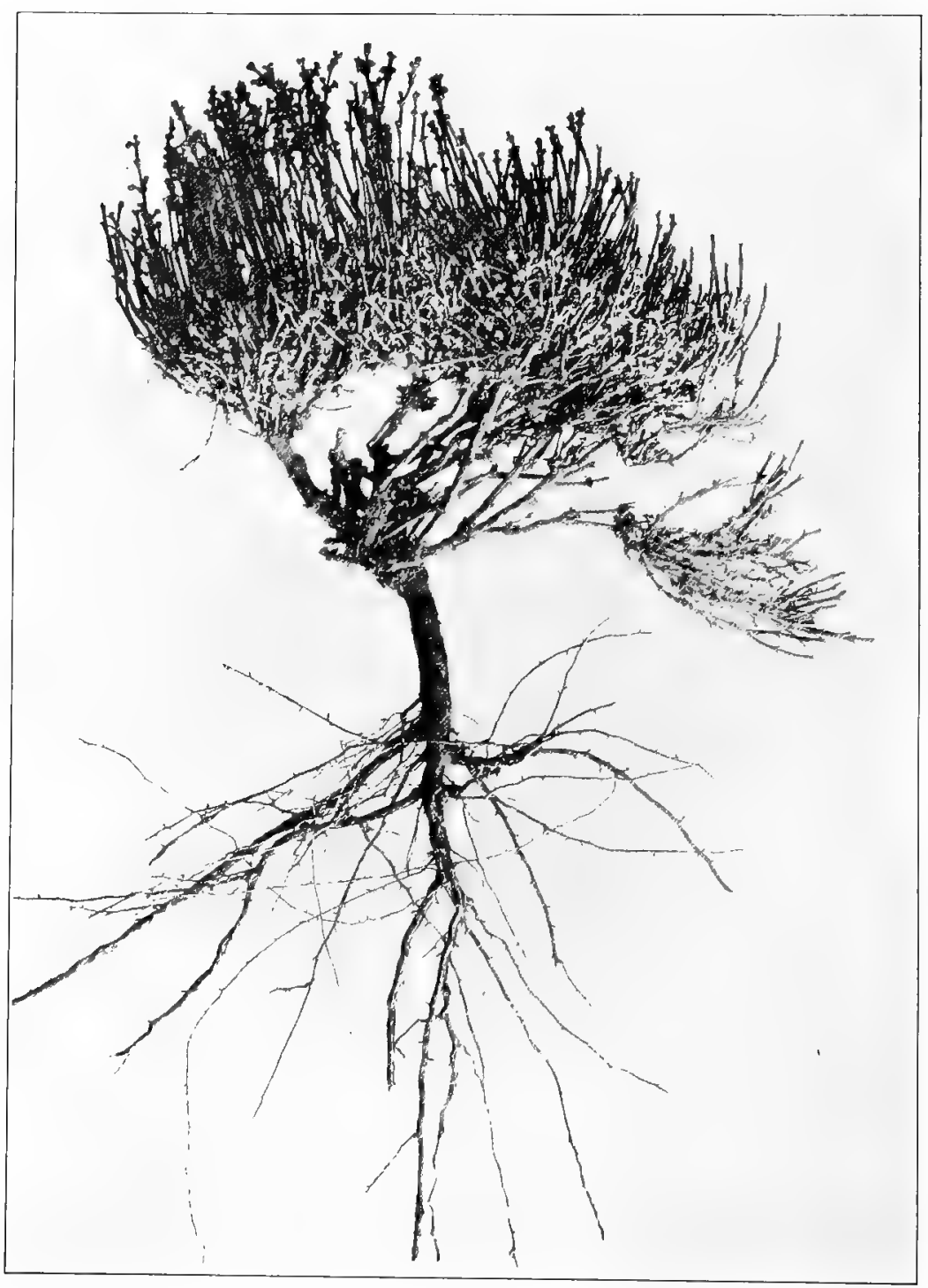

Fig. 56. Anabasis salsa. End of June. 
shoots have short internodes and many small knotted lateral shoots with the leaves arranged in roseltes. The leaves stand close together and are ovate-lanceolate with a small spinose point.

Anabasis salsa (C. A. M.) (Brachylepis).

This species occurs on clayey or stony and saline soil. Its habit is shown in fig. 56. It is an undershrub-chamaephyte, with slightly branched year-shoots which die off almost down to the surface of the ground. They are richly furnished with flowers which arise in the axils of the small opposite scale leaves. The flowers are out in July or August. The fruit is somewhat fleshy, it is surrounded by the nonwinged perianth.

The assimilating stem is constructed after the ordinary centric type of the Chenopodiaceae. The epidermal tissue consists of three layers, of which the inner layer is a thinwalled "crystal-layer". The stomata are slightly sunk. A ring of palisade cells surrounds the starch-sheath and within this is an aqueous tissue with large crystal-cells and the veins.

Anabasis aphylla L.

This species is a saltplant like the previous one and relationship is also shown as regards shoot-structure. In its fruit $A$. aphylla is a true Anabasis, the leaves of the perianth being broadly winged and the fruit dry.

Arthrophytum subulifolium Schrenk.

An undershrub growing on firm soils. It probably does

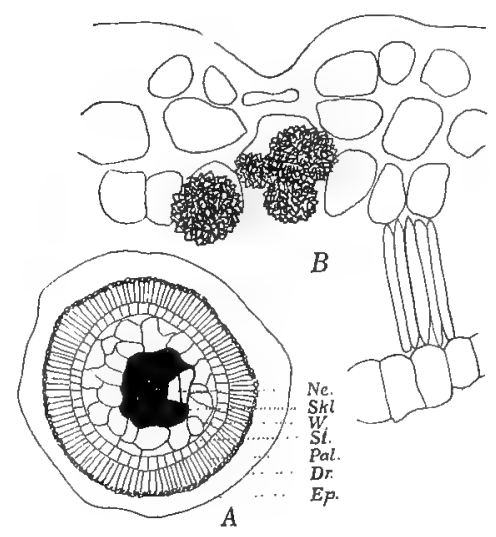

Fig. 57. Arthrophytum subulifolium. A, leaf in transverse section; Ne, vein; Skl., sclerenchyma (black); $W$, aqueous tissue; St, starch-sheath; $P a l$, palisade cells; $D r$, crystal-layer; $E p$, epidermis. $B$, Part of transverse section of a young branch showing epidermis, hypoderm with crystal-cells, palisade cells and starch-sheath. $A, \times 47 ; B, \times 203$. 
not exceed a height of 30 centimetres. Sometines it may be a hemicryptophyte, but in its least protected form it is a chamaephyte with a low thick perennial epigeal base, which bears rather short green branches. These bear opposite subulate leaves with the axils woolly-haired, and with the basal part persisting through the winter.

I have not seen the plant in flower. The fruit is said to be somewhat fleshy and wingless.

As regards the assimilating, epidermal, and aqueous tissues, the structure of the leaf and stem is similar, both belonging to the centric type. A thin-walled hypoderm contains crystal-groups. (Fig. 57).

The Chamaephytes described have the following characters in common: They are undershrubs with a perennial lignified and often thickened base, and with year-shoots the larger distal part of which dies before the next vegetative period. Nanophytum alone is a cushion-plant, or nearly so.

With the exception of Capparis, they have all small leaves, and some of the Chenopodiaceae are practically leafless. In some species all or some of the leaves are shed during summer, and the stems assume the function of assimilating organs (Alhagi, Convolvulus).

The structure of the leaves is isolateral except in Frankenia. The leaves of many species are coated with hairs, some have tracheids, others aqueous tissue.

The year-shoots are almost always branched which is the rule for undershrubs (Warming 1892).

As already stated all the chamaephytes are late flowering. The structure of the fruit so far as I have observed, presents no general characteristic common to all.

\section{Hemicryptophytes.}

The majority of these (see chap. 12, p. 167) are springplants the aerial parts of which are dead during the warmest 
part of summer. So lar as I know this is, for instance, the case with all the Umbelliferae belonging to this lype; and

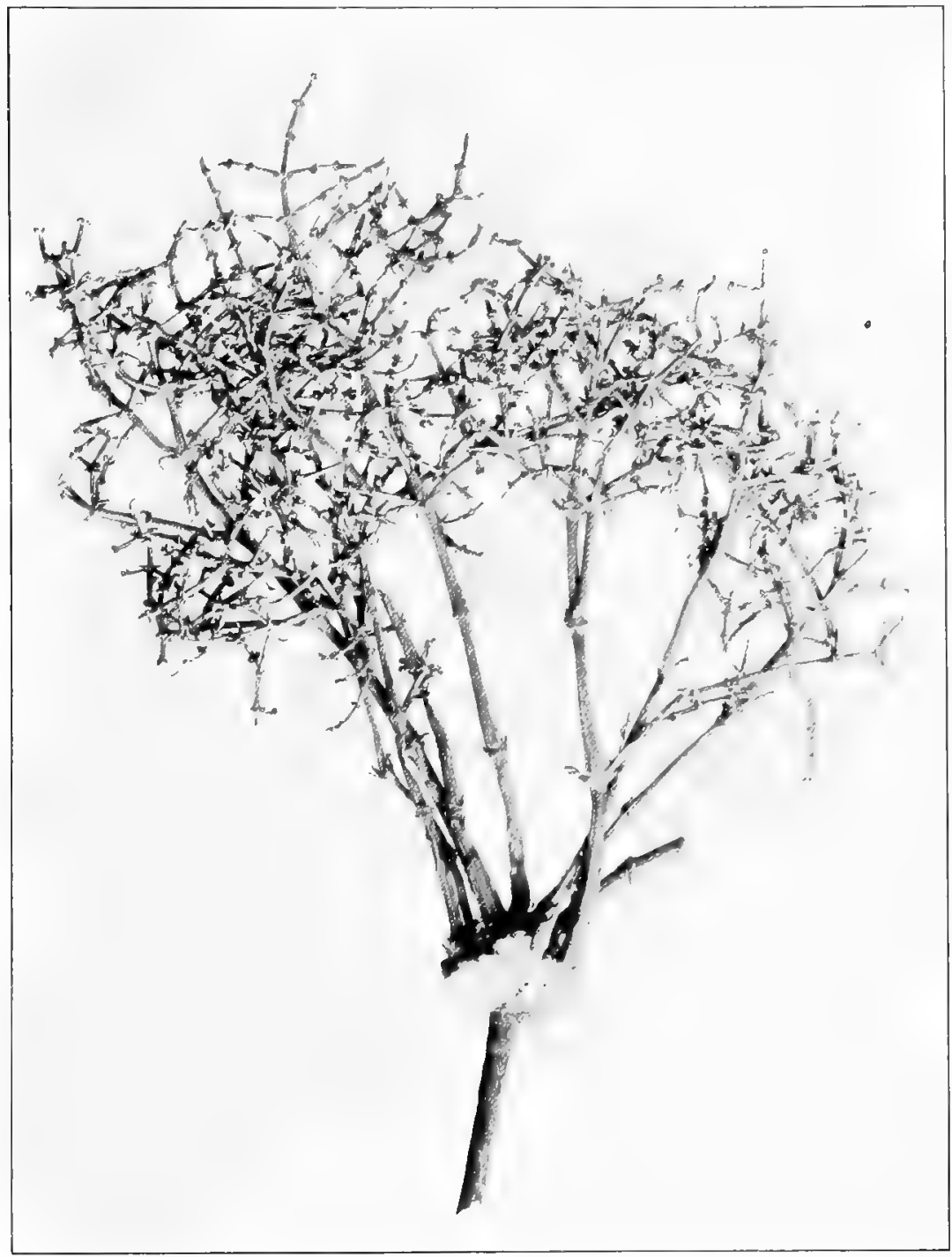

Fig. 58. Anabasis eriopoda. August.

most species of Astragalus and Cousinia, amongst the larger genera, disappear during summer. 
The more important hemicryptophytic summer-plants are some halophytes which will be dealt with below.

\section{Anabasis eriopoda (C. A. M.).}

This species is common in very dry clay- and stonedeserts. It has a very characteristic appearance as will be seen from figures 58 and 59. The year-shoots measure 30 cm. long or even more, and arise from a white woolly cushion which lies in the uppermost crust of soil. The leaves are reduced to small opposite scales, which on older branches terminate in rather long slender spines; in their axils many white woolly hairs occur.

The lower leaf-axils of the year-shoots are branchless. but the upper ones all bear branches. The more vigorous branches give rise to new ones so that a tangle of branches

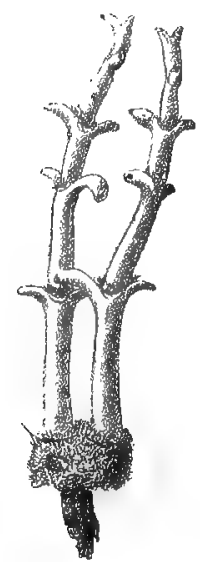

Fig. 59. Anabasis eriopoda. Part of a cushion with two shoots. August. Natural size. results towards the top (fig. 58). All the aerial shoots are annual.

The two lowermost leaves of each shoot are embedded in the cushion whence all the shoots issue, they are very short, but have long apical spines (fig. 59), and their leafaxils are very woolly. The woolly cushion must be formed by the hairs in the lower leaf-axils of successive shoots, and my observations indicate that the shoots arise in these very leaf-axils, though not conclusive enough to prove this positively.

The small inconspicuous flowers open in July, and the fruits which are fleshy and not covered by the perianth ripen during September or October.

The anatomy of the shoots is shown in fig. 60. The epidermis is very thick consisting of three layers; inside it is a thin-walled "crystal layer" which is, however, interrupted in many places. The ordinary layers of palisades are present, likewise a starchsheath and an aqueous tissue. 


\section{Zygophyllum.}

The species of this genus are to some extent at least summer-plants. $Z$. Eichwaldii C. A. M. may he taken as an example. It has long furcate shoots sparsely covered with leaves. These have long stalks and are pinnate with small flat leaflets. The older leaves die off and fall while the apex of the stem is still growing (Translocation of water, comp. above p. 71). The plant flowers in spring (also in summer?), but may still be found with living shools well into summer.

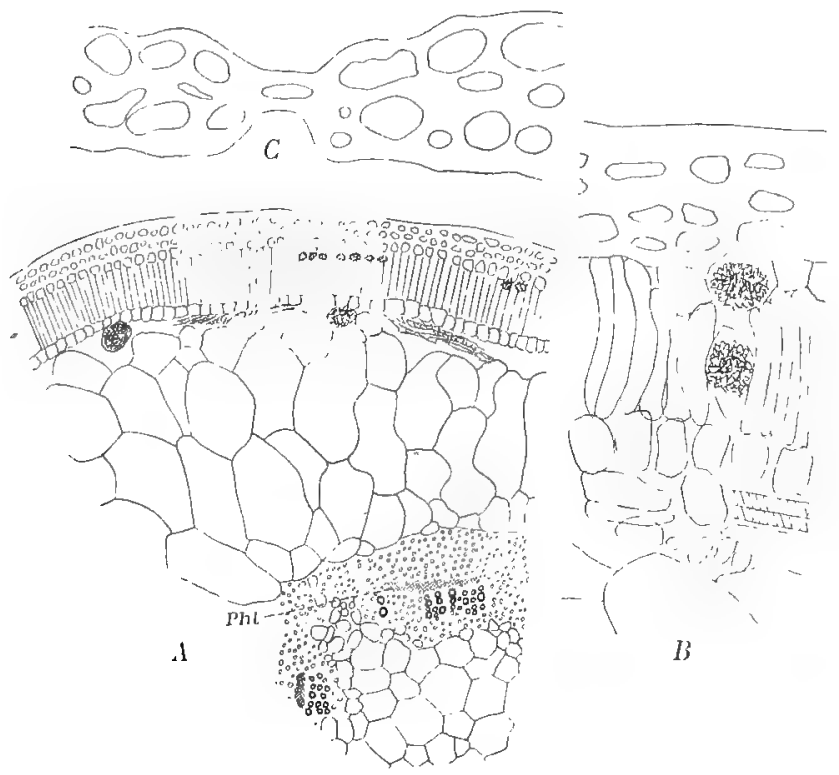

Fig. 60. Anabasis eriopoda. A, Part of stem in transverse section: Phl, phloëm within which lies wood with vessels. $B$, Details of $A ; C$, Epidermal tissue with stoma. $A, \times 47 ; B$ \& $C, \times 203$.

The leaf is isolateral and in contrast to the species described by Warming 1897 (p. 41) and Volkens (p. 113) it consists of palisade cells throughout. These become large1 and more translucent towards the interior, but they all contain chloroplasts, hence there is no aqueous tissue present. The epidermis consists of one layer and seems to be mucilaginous, the stomata are slightly sunk. 
In a young stem the pith is a water-storing tissue. The primary cortex includes bundles of bast at regular intervals. Outside is the green outer cortex with its cells slightly palisade-like.

Zygophyllum Fabago and miniatum both have broader leaves and shorter branches than Z. Eichwaldii.

The leaves of Peganum Harmala are repeatedly furcate with linear segments. The branches lie prostrate on the ground like those of Zygophyllum. It flowers in spring and the shoots wither during the summer. (comp. Volkens p. 114.)

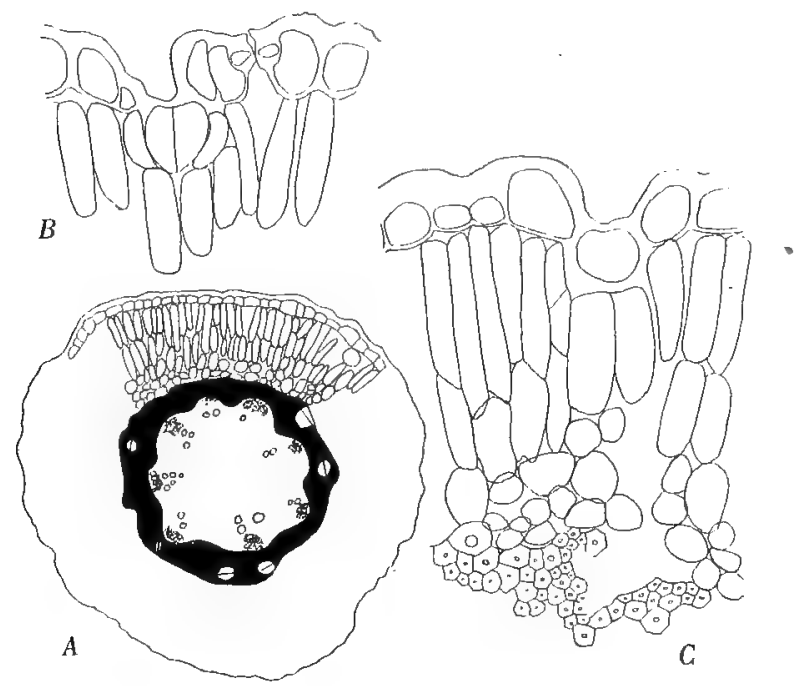

Fig. 61. Stalice ololepis. A, Transverse section of inflorescence-axis. The wood is black, the white holes indicate vascular bundles which are also present within the ring. $B$ and $C$, Details of $A ; B$ shows a gland and a stoma. $A, \times 47 ; B$ and $C, \times 203$.

Statice otolepis Schrenk.

This species has large broad basal leaves which are dorsiventral with two layers of palisades on the upper side, and spongy tissue with stomata on the lower. These leaves die on the approach of summer. Meanwhile the plant has 
flowered in May or June and the richly branched floral axes remain green and persistent, and as in $S$. cordifolia (Ross p. 20) they are the assimilating organs for summer. Their structure may be seen in fig. 61: collateral vascular bundles occur in the pith (comp. Solereder 1899 p. 564); the wood forms a solid cylinder of libriform cells; the cortex consists of green tissue, details of which are given in figures $B \& C$.

Some Summer-Hemicryptophytes occur in the more favourable localities, in depressions near rivers and similar places. These are only slightly xerophytic and have distinct leaves, generally not very large and often hairy. These plants which I have not investigated very closely include, for instance, the following species: Convolvulus pilosellifolius and subhirsutus, Inula caspica, Jurinea derderioides, J. Pollichii, Cousinia trïflora, platylepis and dissecta (spiny), Centaurea iberica, Echium italicum, Lindelofia anchusoides and Aster Tripolium.

\section{Geophytes.}

The majority of these are bulbous plants (comp. chap. 12 , p. 170), and I have only investigated specimens of three important genera Dodartia, Heliotropium and Aristida.

\section{Dodartia orientalis L.}

This species is a RootGeophyte which grows in the more favourable localities on clayey soil. Its leafless branched shoots bear purple flowers in May or June. The branches, as illustrated in fig. 62 , have a thick epidermis and below

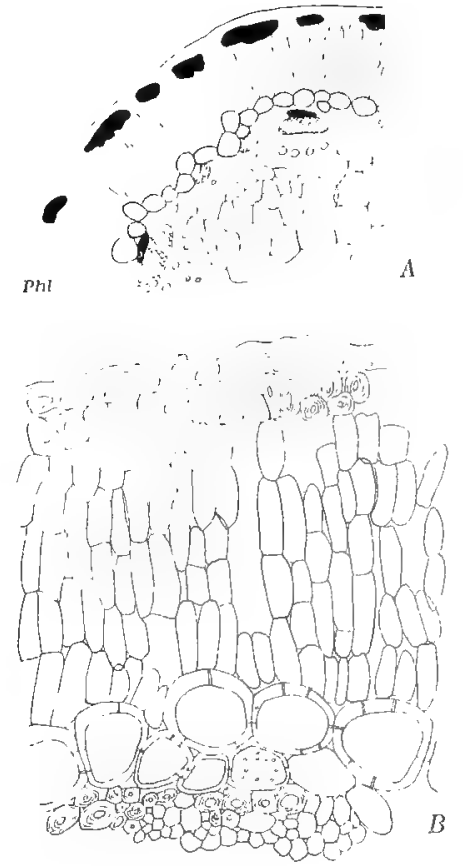

Fig. 62. Dodartia orientalis. A, Part of transverse section of stem; Phl, Phloëm. Sclerenchyma black. $B$, Detail of $A$. $A, \times 47 ; B, \times 203$ ). 
that a hypoderm in which some cells become bast-cells while others remain thin and ultimately disappear leaving empty spaces hetween the bast-bundles. There are 4 or 5 layers of palisade cells of which the innermost are bounded by a storage-sheath of large thick-walled lignified cells with numerous pits. Internal to these are vascular bundles with the leptome sheathed by small bundles of bast, while between the vascular bundles is a small-celled tissue. The pith is a large-celled aqueous tissue.

Heliotropium sogdianum Bge.

This species which has been referred to several times in the preceding chapters (e. g. p. 123, 124), forms long horizontal

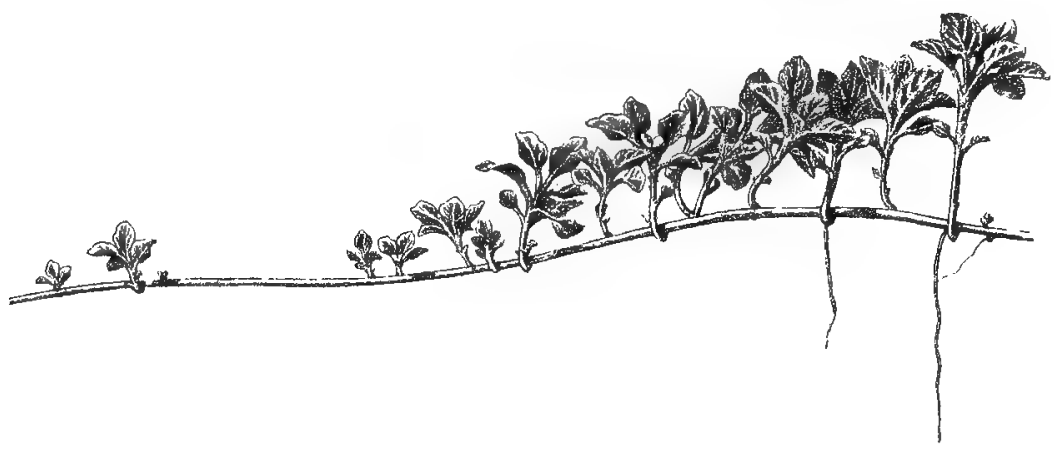

Fig. 63. Heliotropium (Radula?). Part of a horizontal rhizome with aerial shoots.

subterranean shoots from which aerial shoots arise, sometimes widely apart. A creeping stem of this type is shown (fig. 63) densely covered with shoots. At the base of these shoots, roots are often formed. The aerial shoots are frequently rosette-like. The older light-shoots have a white, glossy cortex covered externally with long stiff protruding hairs. The ovate or ovate-elliptical leaves are also stiffhaired. The length of the leaves is $1-1,5(-2)$ centimetres, the veins are very prominent on the lower surface and the depressions between them appear on the upper surface as convexities, so that the leaf has an embossed appearance. 
The hairs on the upper surface are comparatively few, but thick and stiff; they are white and each one occupies a white circular base. On the lower surface these hairs are very numerous. The white flowers are out in May.

Heliotropium Radula, so far as it has been possible to determine the frequently sterile light-shoots, seems to have the same mode of growth and the same form of leaf and hair-coating as $H$. sogdianum. The hair-coating is, however, somewhat closer.

The leaf of $H$. sogdianum is isolateral. The epidermis is one-layered, densely hairy (with hair-cystoliths, see $H$. dasycarpum p. 222), and with slightly sunk stomata on both sides. There are about two layers of short, starch-filled palisade cells on each side. The veins are surrounded by translucent cells.

\section{Aristida pennata Trin.}

This sand-binding grass has been already dealt with (p. 81--83). The thick, shrubby growth of the plant and its power of forming lateral shoots, which add to the tufts and when buried by the sand form new ones, makes this plant the "Conqueror of the Sand-desert" (Antonow) and the most valuable of all sand-binders.

It has been already recorded and illustrated (fig. 9) that the roots are encased by a sand-stocking. Within this stocking the root lies loose, "wie das Bein in der Hose oder, besser und ästhetischer ausgedrückt, wie eine Phryganeenlarve in dem selbst gebauten Gehäuse" (Volkens p. 26). Volkens points out that this sand-stocking is formed by the roots-hairs cementing the sand-grains together, and he is of opinion that its function is to protect the rools against evaporation. This is confirmed by the fact that in grasses provided with a sand-stocking, there is no cork or other corresponding means of protection.

My observations show that the root, which sits loose in the sand-stocking, is devoid of cortex. It is enclosed in a thick-walled pericycle consisting of several layers of prosenchymatous cells with numerous pores and containing starch; 
outside this is a thin-walled endodermis which on its outward side bears shreds of the cortex.

The stocking itself was originally formed by mucilage secreted by the young root; later on the root-hairs penetrate the sand (R. Price), and long after they are dead, they keep the sand-grains bound together. Root-hairs are found on the epidermis which is still entire and forms the inner wall of the sand-tube. The internal diameter of the stocking'

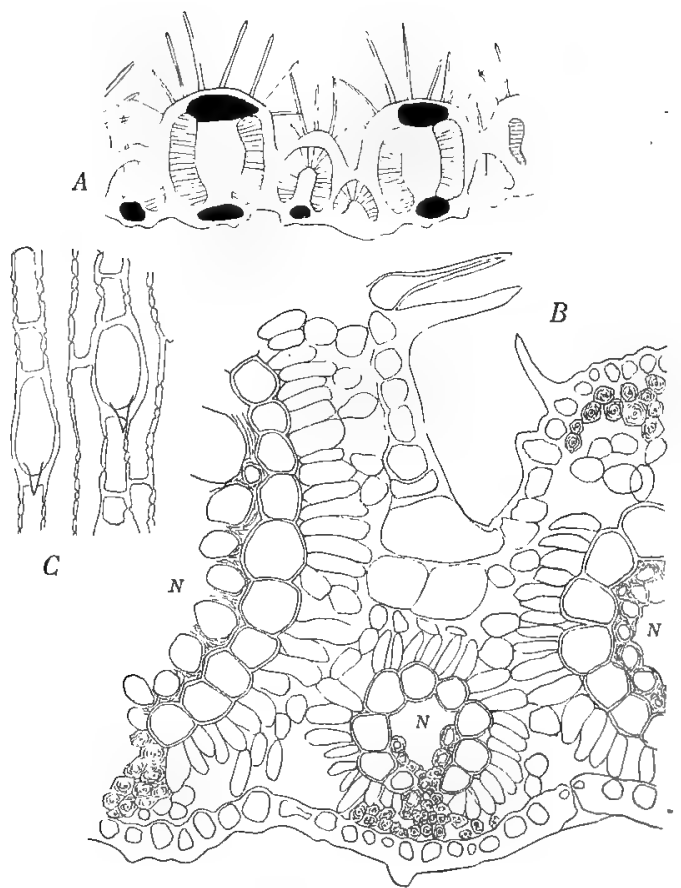

Fig. 64. Aristida pennata. A, Part of leaf in transverse section, slightly diagrammatic. Sclerenchyma black, green tissue shaded. $B$, Detail of $A$. $N$, Veins; $C$, Epidermis of the lower face with hairs. $A, \times 53$; $B$ and $C, \times 203)$.

thus indicates the original thickness of the root, but from the disappearance of the primary cortex the root becomes so thin that is lies loosely in the tube.

The straw or haulm is solid and the vascular bundles lie scattered in a somewhat thick-celled tissue; each of them 
has 3-4 vessels and a leptome group, while down both sides there is a strand of sclerenchyma.

The anatomy of the leal has been described in the closely related, perhaps identical species, Aristida pungens, by Duval Jouve (tab. 17, fig. 7) and Tschirch (tab. 6, fig. 3). The Transcaspian specimens examined by me agree in their chief features with what has been found by these authors, yet it seems to me that the single cell-layer of the green tissue has a more pronounced palisade-form, and that the whole leaf has larger internal air-cavities than in the figures cited. Some figures of the structure of the leaf are given in fig. 64 . The leaf can roll up lowards the inner (upper) surface which has long hairs, and the epidermis includes hinge-cells. Like all Paniceae, the plant has the veins surrounded by a starchsheath which is open on the leptome side in the larger veins, while round the smaller ones it is interrupted on both sides; this again is surrounded by a palisade layer. In my specimens the lower surface is also furrowed, though faintly, and in the furrows opposite the air-spaces amongst the green tissue of the "prisms" there are stomata which are slightly sunk; other parts of the epidermis are covered with short, pointed hairs (fig. 64, $B, C$ ).

\section{E. Therophytes.}

It has been repeatedly staled in previous pages that some of the Therophytes are ephemeral spring-plants, while others - the smaller number - are summer-plants which persist through the dry, warm summer. The following includes observations on some of the species belonging to the latter group. The ephemeral species might likewise repay a careful investigation, for instance their variability as to xerophilous structure, depending on the soil and time of development, would be well worth examining. The material available did not, however, permit of such an investigation, particularly as regards anatomy. But the summer-plants seem to me more interesting, and during the journey my attention was chiefly directed towards them and towards collecting material of them. 
Cousinia.

Many Transcaspian species belong to this genus, most of them perennials. They are all rather broad-leaved, thorny, and frequently "cobweb-haired". C. annua and C. dichotoma were examined as examples of annual species. The former I found flowering in the sand-desert during the holtest time of summer. It was about half a metre high and had broad spiny leaves the axils of which bore rich dense inflorescences. The plant is glabrous, the stem snow-white and glossy.

The leaf is somewhat dorsiventral with two lavers of palisade cells on the upper side and one on the lower, and a rather loose spongy paranchyma. The veins have baststrands, the larger ones projecting as ridges on the lower face.

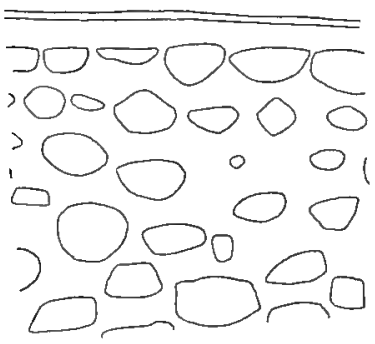

Fig. 65. Cousinia annua, Epidermis and collenchyma of stem. $(\times 203)$.

They lie several together, quite separate or connected by a translucent aqueous tissue which merges outwards into a collenchymatous tissue.

The epidermis is rather thinwalled and has stomata on both sides, slightly sunk.

The stem is without green tissue, and has a thick epidermis over a deep thick-walled collenchyma (fig. 65) all the way round.

Cousinia dichotoma is a smaller plant which may still be found flowering at the beginning of July, but it begins to wither about this time. The broad, spiny leaves still preserve their form and position because well-provided with sclerenchyma; they are somewhat dorsiventral and have stomata (not sunk) on both faces as in C. annua.

\section{Frankenia pulverulenta L.}

A slender plant with decumbent branches. Like $F$. hirsuta (see p. 222) it occurs most frequently on somewhat moist soil. The leaves are small and flat with salt-crystals on both faces; the glands which are figured by SoLEREDER 
(p. 121), thus occur on both surfaces, and the same is the case with the stomata (in contrast to the statement made by Volkens 1. c. p. 109). On the other hand, the long hairs are only found on the lower side. The leaf otherwise is dorsiventral with two layers of palisade cells on the upper side and a rather loose spongy parenchyma.

\section{Crozophora gracilis F. \& M.}

An herbaceous plant with outspread branches and longstalked ovate-cordate leaves which are covered on both surfaces with a thick felt of stellate hairs. The plant occurs in places where the soil is not too dry, and it is still in flower in the month of July. The leaf is dorsiventral with one layer of long palisade cells on the upper surface, and one layer of short ones on the lower; there is no aqueous tissue. Crystalcells are present in considerable number. The epidermis consists of one layer and has slightly sunk stomata on both leaf-surfaces.

\section{Euphorbia Turczaninowii Kar. Kir.}

(E. carnosa Pauls.).

A thick-leaved, green, glabrous plant, attaining the height of about 10 centimetres. Like the previous species it occurs in more favourable localities. It is rarely found in flower in July although it frequently has fruits at that time of the year. The sessile, broad leaves are directed obliquely upwards, and are isolateral in structure. There is a thin epidermis with slightly sunk stomata on both surfaces.

\section{Euphorbia cheirolepis F. \& M.}

An erect plant with rather long internodes; habitat the sand-desert. The leaves are about one centimetre long, petiolate, obovate, spinose-toothed; the upper surface is shining and cobweb-haired, the lower is almost woolly-haired. They are dorsiventral, yet with stomata (slightly sunk) both above and below. The epidermis is thin. The dorsal side has a layer 
of long palisade cells over a spongy parenchyma which has its lowest (green) layer of cells slightly palisade-like, and below this is still another palisade-like layer of cells which is colourless and must be designated an aqueous tissue.

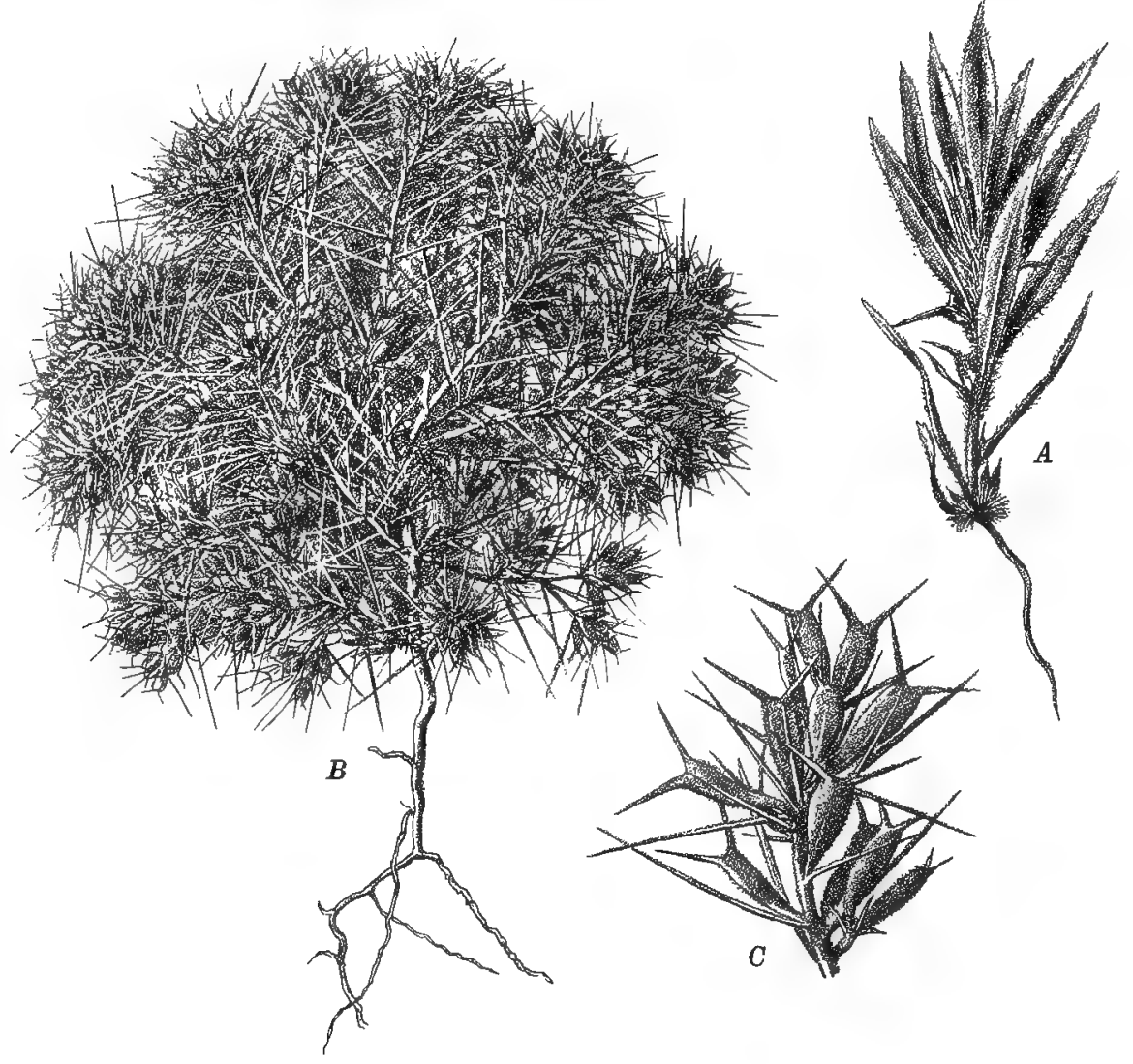

Fig. 66. Ceratocarpus arenarius, A, A young plant with green leaves and a few fruits in the axils. May. (natural size). $B$, An older. plant, (reduced one-half). $\quad C, A$ branch of $B,(X 2)$. The parenchyma has disappeared and the midribs remain as spines. August.

\section{Ceratocarpus arenarius L.}

This very common plant occurs both on sandy and clayey soil; Fig. 66 shows its appearance. In spring the 
leaves are distinctly linear-lanceolate and bear single flowers in their axils (fig. 66, A). The plant is coated with stellate hairs. The leaves are isolateral with about two layers of palisade cells on each side and a number of crystal-cells. The midrib is surrounded by a thick sclerenchyma extending often from epidermis to epidermis. The small veins are surrounded by translucent storage cells. The epidermis consists of one layer, not very thick-walled, and has stomata (not sunk) on both sides.

In August Ceratocarpus resembles a spiny ball (fig. 66, $B, C$ ). The leaves are reduced so that only the midrib remains, and even if some still seem to retain their lamina, an anatomical examination shows lhat all the cells are collapsed and dead. At this season of the year all the leaves are thus reduced to thorns, and the assimilating functions are carried on by the two connate prophylls which form the two-thorned fruitspathes (see fig. 66 C). A section of the wall of the fruit-spathe shows (fig. 67) that the inner surface is formed of two lignified thick-walled layers, the second of which shows

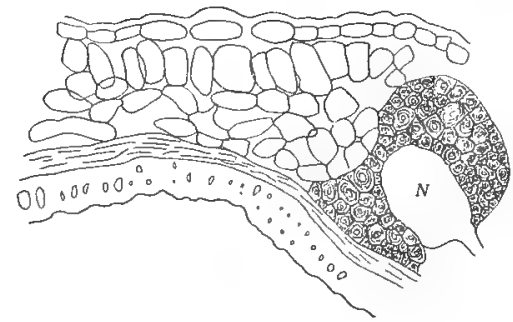

Fig. 67. Ceratocarpus arenarius. Transverse section of part of the fruit-spathe (Prophyll). (X 203.)

no cell-cavities; beyond these skeleton-cell-layers there lies an assimilating parenchyma made up of one layer of short palisade cells and 1 or 2 layers of transverse cells loosely arranged. All the cells are filled with starch. The veins (N) are enclosed in bundles of bast above and below, especially the two veins situated near the two margins of the spathe.

Cornulaca Korschinskyi Litw.

An erect sand-desert plant thickly covered with short acicular leaves (fig. 68). Each leaf-axil gives rise to a rosetteshoot bearing many leaf-thorns, and in every leaf-axil, (i. e. on the lower parts of the leaves) there are a great number 


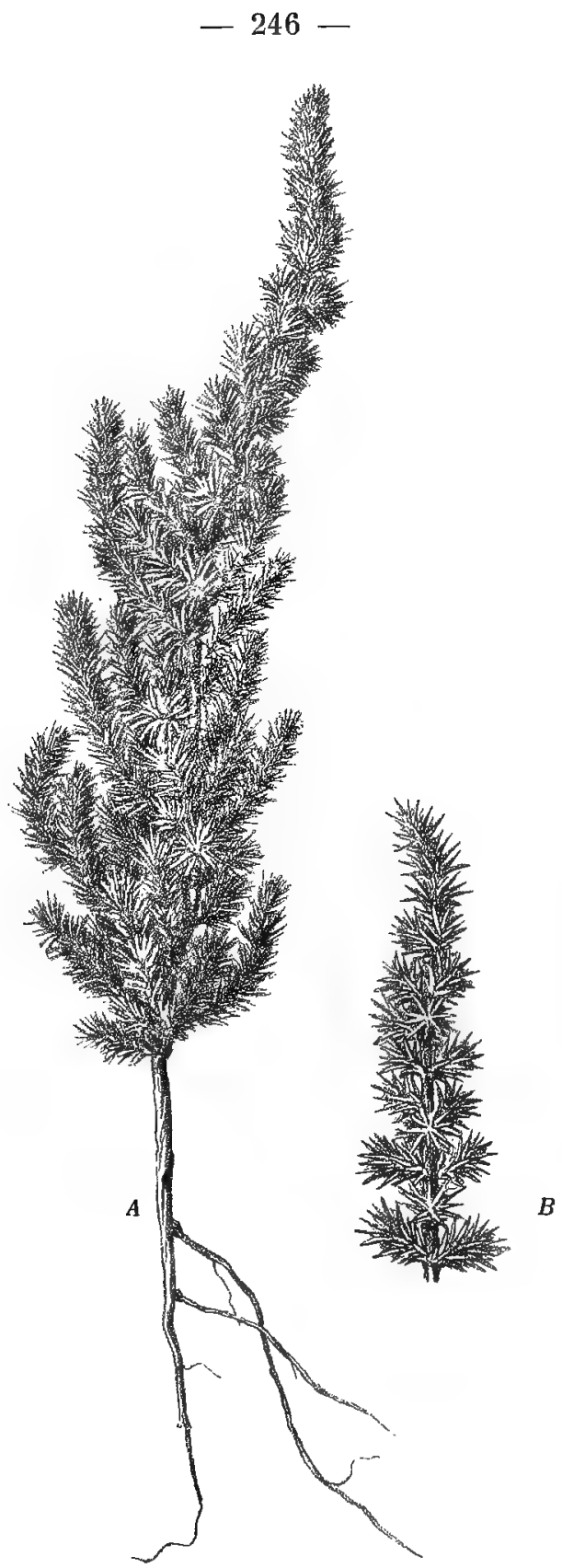

Fig. 68. Cornulaca Korschinskyi. A, Plant, half size; B, Branch, natural size. June. 
of white, woolly hairs. These are slightly over $1 \mathrm{~mm}$. long and are arranged in bunches. Each hair consists of one, two or three rows of cells, the thickness decreasing from below upwards (fig. 69).

The leaf is constructed after the ordinary centric type and resembles that of Horaninowia ulicina (fig. 71): There is an epidermis of one layer with large papillæ, a crystal-layer, one layer of palisade cells with a starch-sheath, a thin zone of aqueous tissue, and a thick sclerenchyma enclosing the vein.

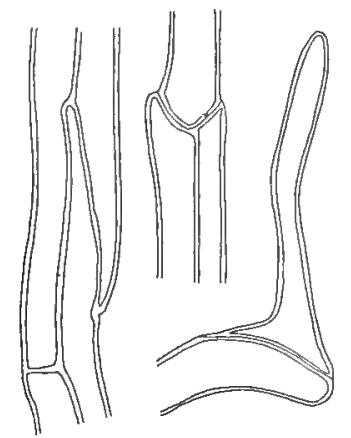

Fig. 69. Cornulaca Korschinskyi. Parts of axillary hairs. $(\times 302)$.

The small flowers do not open till autumn. The perianth remains round the fruit and bears a spine $4 \mathrm{~mm}$. in length.

Horaninowia ulicina F. \& $M$.

A sand-desert plant with decumbent branches and acicular leaves. The branches may attain a length of 20-30 centimetres (see fig. 70), with long internodes between the pairs of opposite leaves. In the woolly-haired axils of the more or less cylindrical thornlike leaves, there are either rosette-shoots, or more or less elongated long-shoots, or flowers. The leaves on the main branch die rather early but the axillary shoots remain green.

In favourable localities the leaves may attain a length of a couple of centimetres, and the shoots are erect (var longifolia.) 
With regard to the structure of the leaf and stem, reference to fig. 71 renders any description unnecessary. The

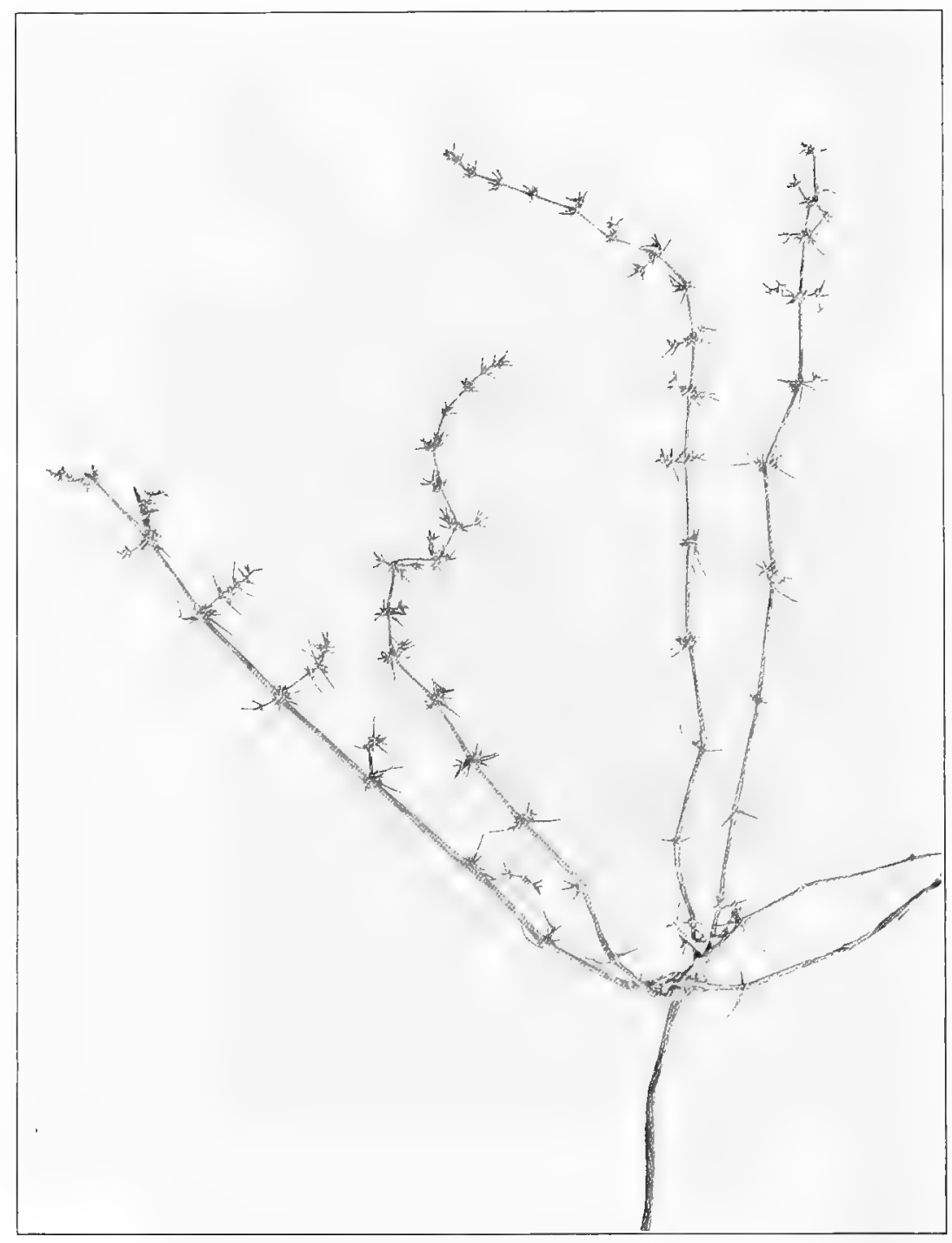

Fig. 70. Horaninowia ulicina. Part of a plant, July.

stem has bands of green tissue alternating with bands of collenchyma (fig. $71 \mathrm{C}$ ). 
Agriophyllum minus F. \& M.

A strongly branched, thorny-leaved sand-desert plant which may attain a height of about 30 centimetres: fig. 72 illustrates a small specimen. The leaves are up $103 \mathrm{~cm}$. long, flat with stellate hairs, hard in texture, parallel-veined and traversed by parallel ribs and furrows, and terminate in a spine. The lower ones are lanceolate, but higher up they become narrower. The leaf-axils bear short-shoots with

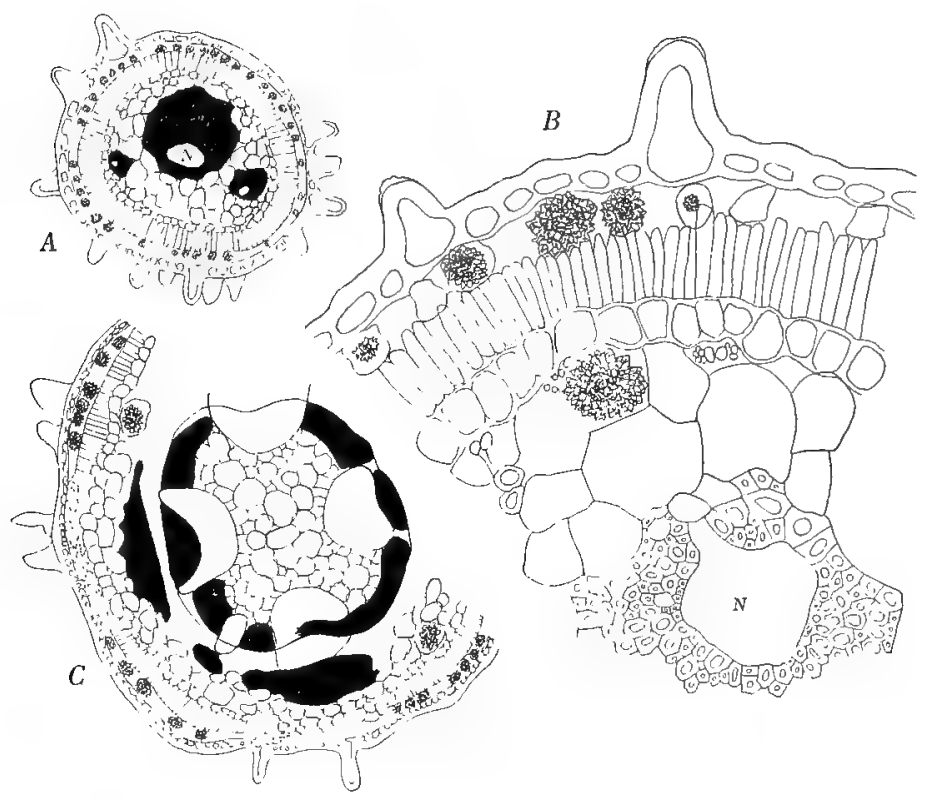

Fig. 71. Horaninowia ulicina. $A$, Transverse section of leaf; $N$, Vein. $B$, Detail of $A$. C, Part of transverse section of stem. Sclerenchyma black, collenchyma dotted, palisade tissue shaded. $(B, \times 203 ; A$ and $C, \times 53)$.

leaves which are quite narrow, acicular and ending in a straw-coloured spine. The flat leaves die away in the course of summer, while the short-shoots remain green.

The structure of the isolateral leaf will be seen from fig. 73. The superficial ribs consist of bands of sclerenchyma. There are one or two layers of palisade cells on each side, and translucent cells with numerous crystal-cells in the middle.

The stem shows bands of collenchyma alternating with 
bands of green tissue which have about two layers of low palisade cells supported by transverse storage-cells. Where root and stalk merge into one another, the axis is thickened and succulent. No green tissue occurs here but the collenchyma extends all round.

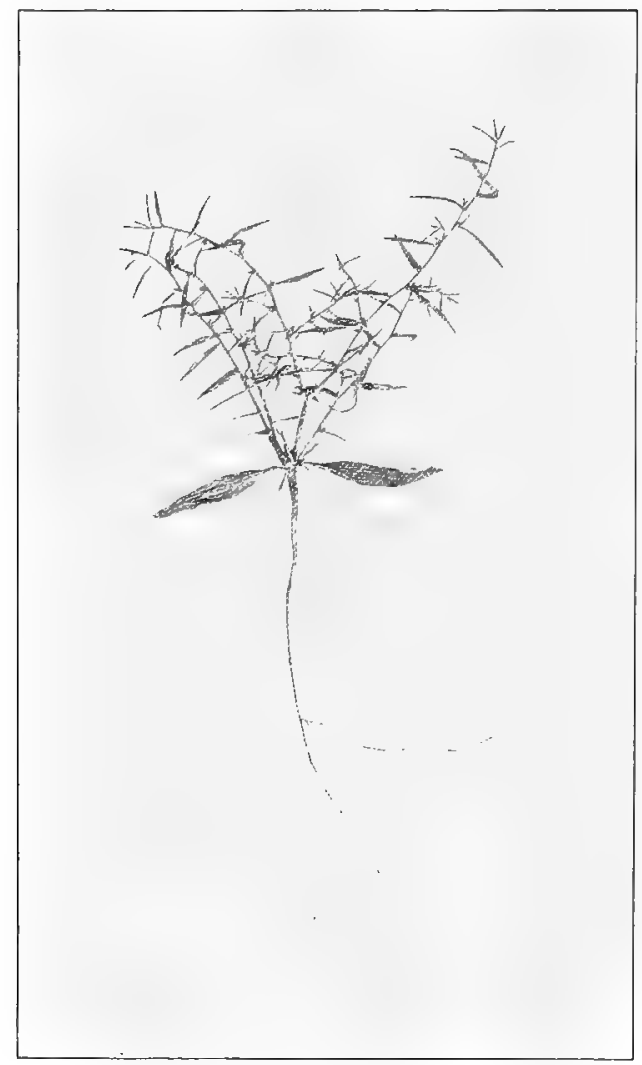

Fig. 72. Agriophyllum minus. June.

Agriophyllum latifolium F. \& M.

This resembles the previous species, but the lower leaves, which gradually disappear, are ovate-elliptical to broadly cordate with pinnate venation (fig. 74). They are covered with scattered stellate hairs and end in a spine. Higher up 
the plant the leaves become narrower with the spine longer; the uppermost leaves as well as the leaves of the rosettes are sessile and acicular as in the previous species. The leaf is not ribbed as in $A$. minus but the structure of the green tissue is almost the same. The veins have a thick bast-

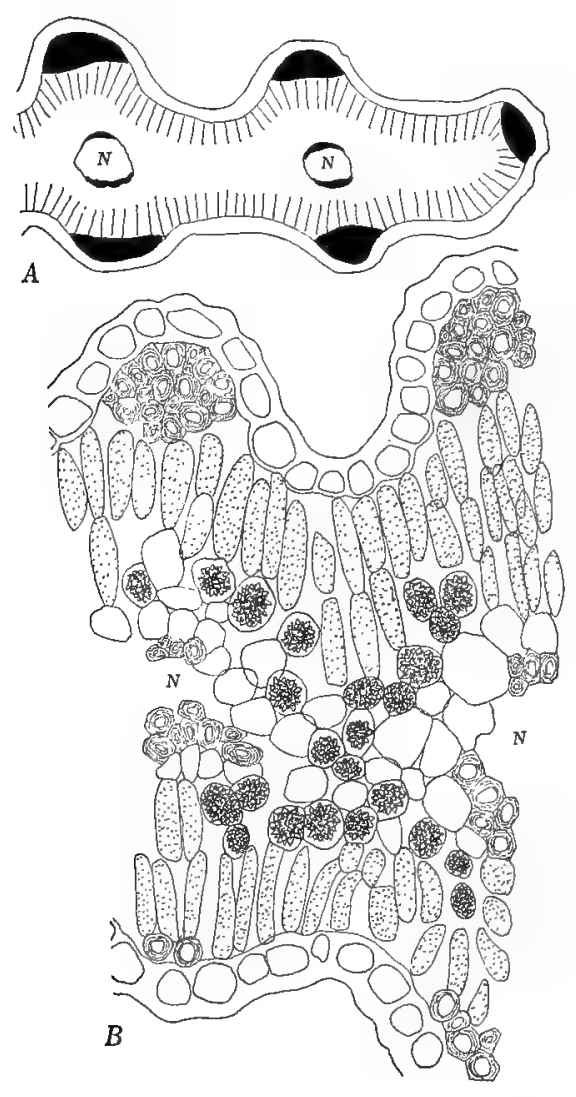

Fig. 73. Agriophyllum minus. A, Transverse section of leaf, showing the distribution of sclerenchyma (black), palisades (striped) and veins (N). B, Detail of $A ; N$, Veins $(A, \times 53 ; B, \times 203)$.

sheath and a strand of bast runs along the margin. The stem (fig. 75) has thick hypodermal ribs of sclerenchyma and is better provided with green tissue than the previous species. Lying within the palisade tissue there is a layer of storage cells interrupted by the bast-bundles of the leptome. 
Salsola.

This genus includes a number of leaf-succulents some of which are thorny (S. Kali, aperta, sogdiana, Androssowii) while others (S. crassa, lanata, clavifolia) are thornless; also some

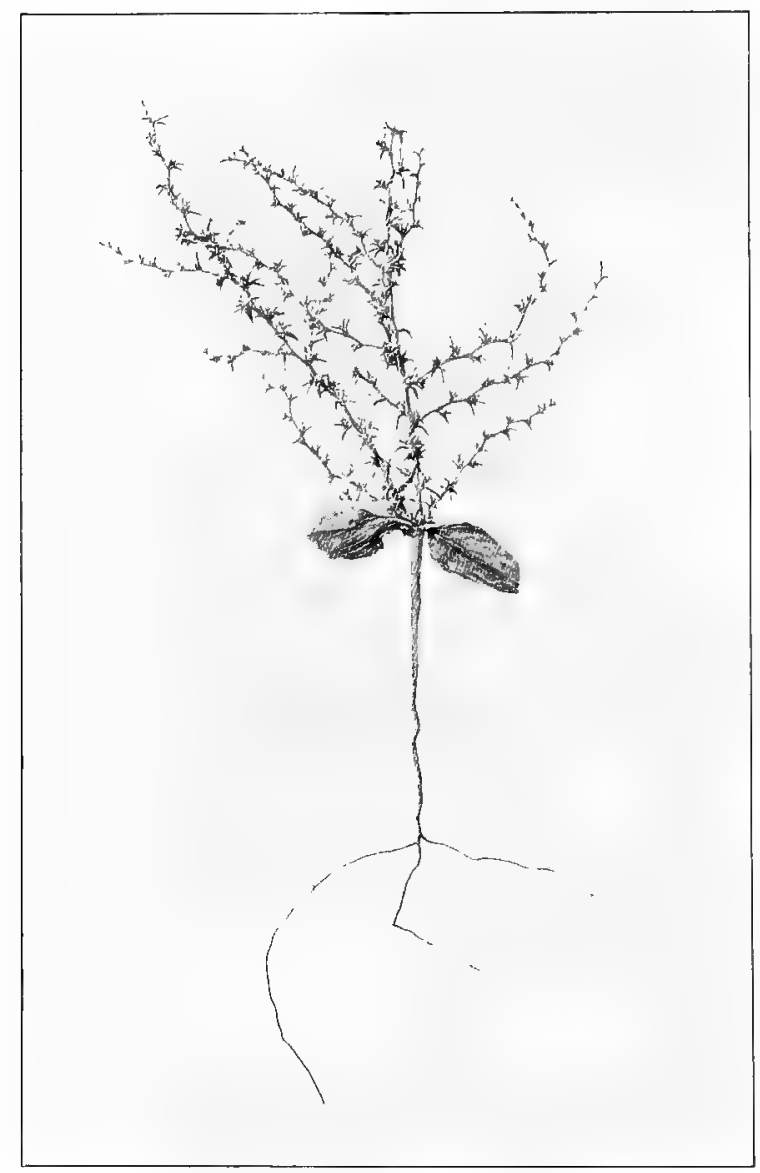

Fig. 74. Agriophyllum latifolium. June.

bracteole-succulents (comp. above p. 71), namely, Salsola spissa (fig. 8), incanescens and sclerantha.

I have examined S. sogdiana (fig. 76) and S. aperta both of which have thorny-pointed, semicircular leaves, and found them to have the ordinary centric structure like $S$. Kali (see 
Warming 1897 p. 216). The bracteoles in $S$. spissa and $S$. sclerantha are similar in structure. The latter species is white-haired.

Halocharis hispida C. A. M.

A clay-and salt-plant with stiff hairs which give it a greyish colour. The leaves are more

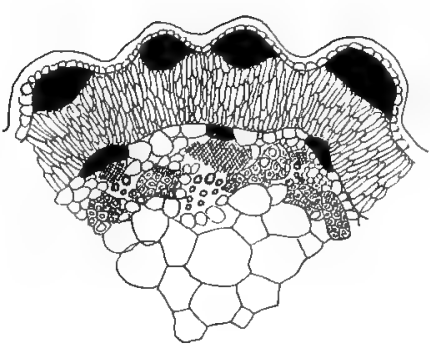

Fig 75. Agriophyllum latifolium. Part of a transverse section of stem. Bast in black, leptome crosshatched. (X 53). or less cylindrical and longhaired, especially at the apex; they are very closely arranged on short-shoots arising in the leaf-axils. These short-shoots

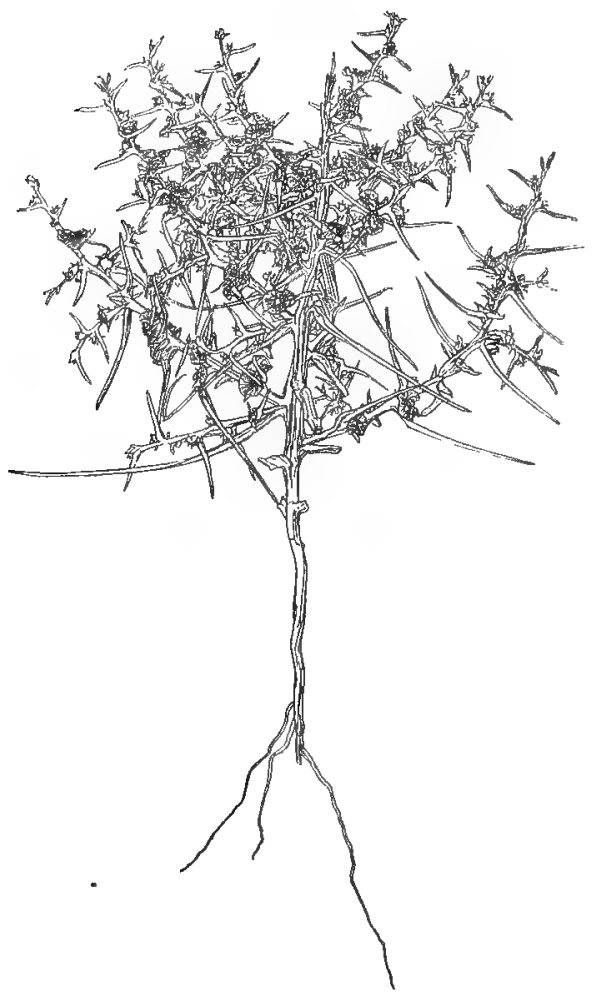

Fig. 76. Salsola sogdiana in fruit. June. 
may stand so close at the tips of the branches that the plant becomes almost globular.

The anatomy of the leaf is of the ordinary centric type. There are two sorts of hairs: some are long stiff multicellular hairs, but more abundant are the short, stiff unicellular ones. No hypodermal layer of crystal-cells is present, but these cells are numerous in the green tissue and in the aqueous tissue. The epidermis is one-layered, with stomata slightly sunk.

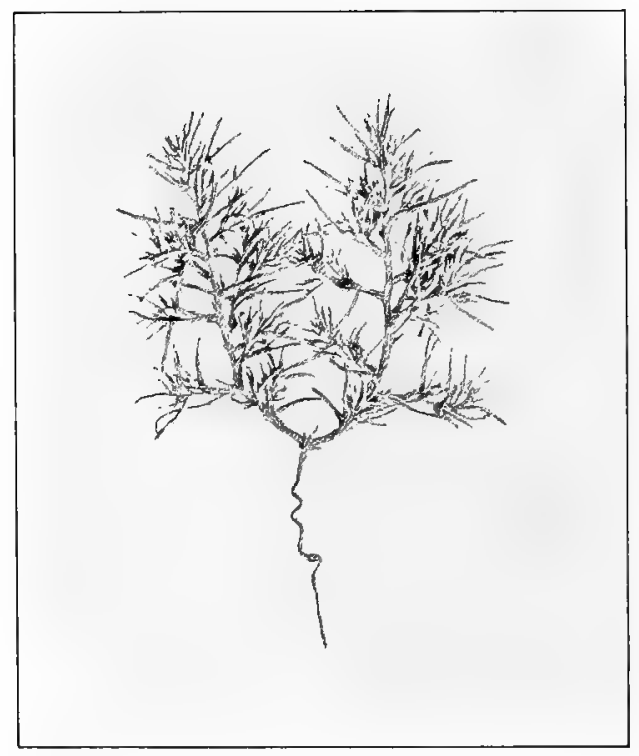

Fig. 77. Halimocnemis pilosa. July.

\section{Halimocremis.}

This genus is characterised by the ripening fruit, the perianth of which developes no wings or other protuberances, whereas the leaves harden and coalesce thus forming a protective cupule in which the fruit is placed. The species are true summer-plants growing on clayey and saline soil.

The habit of $H$. pilosa is illustrated (fig. 77), and related to this we have $H$. macranther $a$ and $H$. villosa. These species 
have long triangular and hairy leaves, the upper ones subtending the solitary flowers.

$H$. villosa and macranthera, probably also $H$. pilosa, have leaves constructed after the ordinary centric type. Since the leaf is thick the aqueous tissue in the middle is large; the midrib has a bast-sheath; the hairs consist of a basal cell and a long filamentous cell; the stomata are not sunk.

The leaves of $H$. Karelini (fig. 78), a bracteole-succulent, are similar in structure; they have very short hairs and the stomata are slightly sunk.

Closely related to the long-leaved species of Halimocnemis both in appearance and inner structure we have Halanthium gamocarpum, and probably also Piptoptera turkestana, the anatomy of which I have not examined.

Suaeda.

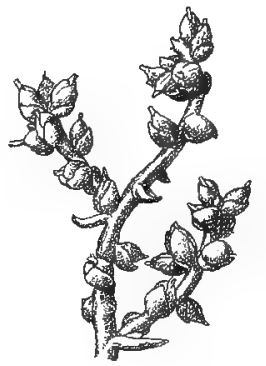

Fig. 78. Branch of Halimocnemis Karelini. July. (Nat. size).

The leaves of a number of species of this genus have been examined. As regards leaf-structure these may be divided into three groups.

The leaf-structure of the species of the first group is similar to that already described for $S$. maritima (see for instance WARming 1897, p. 207, 1890, p. 221). Below the thin-walled epidermis there is a green mesophyll of palisadelike cells which become larger and contain less chlorophyll towards the interior; the veins lie in a curve in the middle of the leaf. Other species belonging to this group are: $S$. setigera and S. Olufsenii (from Pamir), also $S$. linifolia which differs in having flat leaves with ordinary isolateral greentissue.

The second group of Suaeda has underneath the epidermis a single layer of palisade cells all round and a starchsheath below this (fig. 79, B). Thus far these leaves follow the ordinary centric type of the Chenopodiaceae. But those veins, which in other organs of this type run obliquely through the central aqueous tissue and arrange themselves 
beside the starch-sheath, are here wanting. The aqueous tissue must therefore be capable of translocation and we also find that all its cells contain chlorophyll, though very little.

The veins, like those in the first group, lie in a curve with the concave side upwards (fig. $79, B$ ). In longitudinal section they are seen to branch reticulately within the curved plane, the transverse section of which is the curve mentioned, but not outside it. To this second group belong $S$. pterantha, altissima, Lipskii, arcuata and dendroides.

$S$. microsperma is the only one of the species examined by me which belongs to the third group. As shown in
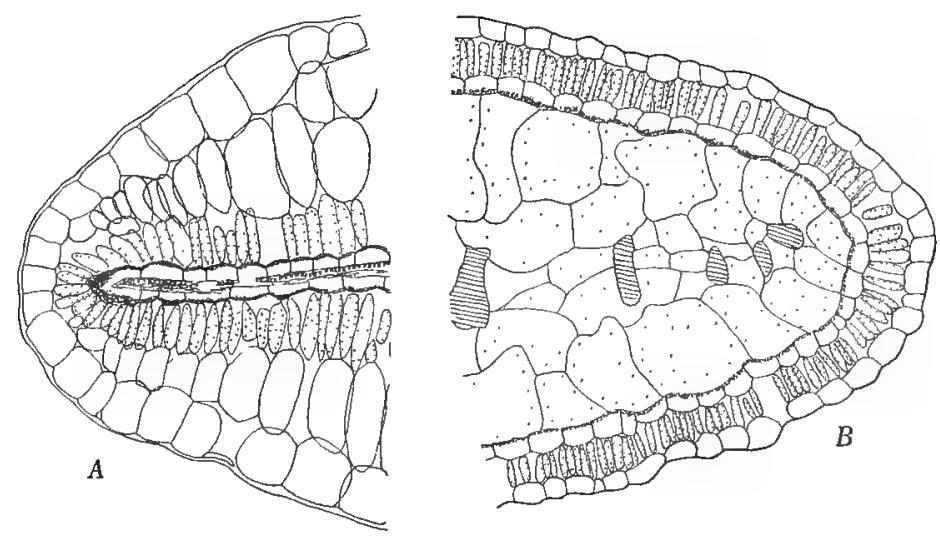

Fig. 79. Transverse sections of: A, Suaeda microsperma; B, Suaeda Lipskii. In $B$ the veins are indicated by horizontal hatching. ( $X 203$ ).

fig. 79, $A$, the palisades and the starch-sheath of this species lie internal to the aqueous tissue which is quite translucent. The starch-sheath immediately adjoins the arc in which the veins run and branch.

\section{Halopeplis pygmaea (Pall.) Bge.}

A halophyte with sheathing and almost globular leaves. The epidermis is not very thick and the stomata are not sunk. About three layers of rather loosely arranged palisade cells are present, abutting internally on the network of finer veins which in lurn are linked up with the primary vein by 
larger branches. Internal to this network of finer veins there is a translucent aqueous tissue. The structure of the leaf thus resembles that of Halostachys caspica (see above p. 201).

Some of the herbaceous plants described under C, D and E, are Halophytes e.g. Halopeplis, Suaeda, Halimocnemis, Salsola, Halocharis, Anabasis, Statice and Zygophyllum. With the exception of the two last-named they are Chenopodiaceae and have thick assimilating organs of the centric type, which is also the case with the vicarious branches of Statice. Linked with Zygophyllum we have Euphorbia Turzaninowii, both being thick-leaved and isolateral. Other representatives of the Chenopodiaceae are xerophytic plants (Cornulaca, Horaninovia, Agriophyllum, Ceratocarpus). They are spiny, with the assimilating organs thin and not succulent, but in the two first-named the same centric structure is observed, although on the whole they are better provided with sclerenchyma; to the same category belongs Dodartia. - Heliotropium and Cousinia are more nearly related to the hemicryptophytes with a more pronounced mesophytic structure (see p. 237) since they have flat leaves not much modified. Such leaves are as a rule isolateral, but dorsiventral also occur (Frankenia, Euphorbia, Crozophora).

The fruits exhibit a variety of types.

The material of herbaceous plants available is however insufficient to furnish a reliable general summary of the conditions of structure. The foregoing must therefore be regarded as a series of examples illustrating the different modes of adaptation to the conditions of life in Transcaspia.

If we endeavour, in conclusion, to summarise the features of all the plants described in this chapter, - keeping, however, in mente the Spring-plants - it is possible to formulate under three heads some of the specially characteristic features of Transcaspian desert-plants.

1. The difficulty attending the development of longlived aerial shoots. In this connection one must consider 
the large number of spring-plants with light-shoots which only live a short time, and also the chamaephytes and fanerophytes on which annual shoots are common, but where the persistent shoots of most species lose their distal parts.

2. Reduction of the leaves. It is a well-known feature of deserts that the leaves become small or disappear entirely. As a rule the stem assumes the part of vicar, it may be in some cases where leaves are still present, as assistant vicar, or in other cases, where leaves are entirely wanting, as deputy-vicar (B. Jönsson 1910). BorRIvant has proved by experiments a correlation between absence of leaves and formation of assimilating tissue in the stem.

3. The frequency of the centric type of assimilating organs (in and outwith the Chenopodiaceae) and of isolateral leaves. Isolateral structure seems to be specially dependent on strong light (Heinhicher), and it must promote the process of assimilation. The xerophytic structure of the assimilating organs is likewise a well-known feature in desert plants as recorded in the various text-books on plant-geography; see also HensLow 1893, with whose interpretation, however, I do not agree.

\title{
SECTION IV. THE FLORA OF THE TRANSCASPIAN LOWLANDS.
}

\author{
CHAPTER 14
}

\section{The Elements of the Flora.}

When at the beginning of the Quaternary period Transcaspia emerged from the sea which retreated towards the West and North, a change in climatic conditions took place simultaneously in the various parts of Western Asia previously 
washed by this sea. In this earlier period the climate, which was probably rather moist, had been favourable to the growth of plants and had resulted in a luxuriant and fairly homogenous flora developing over the immense area between the Himalaya and the Pyrenees. When the sea disappeared the climate became dry. The plants came under the influence of a very different environment so that they were compelled to change. Only in the northern part of the Elburs and the western part of the Caucasus, near two great inland seas, are luxuriant forests still found which are regarded as the last, though perhaps somewhat altered, remnants of the old tertiary vegetation of Western Asia. The rest of the plants must either die or adapt themselves to the new conditions. At the same time the Aralocaspian lowlands, left by the sea, were open to immigration from the neighbouring countries. The result of the changes which took place was a new flora, xerophytic and especially adapted to a climate with a short vegetative period, but which was - and is - otherwise closely related to the elements of the flora of the Mediterranean lands with which they have a common origin ${ }^{1}$ ).

If the development took place as indicated here according to ENGLER, it is evident that the flora of Transcaspia must for the most part have originated from that of Western Asia, and that the plants must have descended from the mountainous parts towards the South and East (comp. Borsczow, above p. 30). Southern Russia cannot come under consideration as a starting point for the species which populated Transcaspia, because large tracts of it at the beginning of the quaternary period (SJögren, see also Karpinsiri) were covered by water (the Aralocaspian Sea) and this "Caspian Transgression" probably originated in ice-water from the margins of the great European ice-sheet, so that the climate must have been cold. With regard to the climate of Western Siberia at that period there is no information, but it must also have been cold, colder than now, therefore the possibility of immigration from there need not be considered.

1) Engler 1879, pp. 57 and following, 184 and following. 
If the flora of Transcaspia originated thus from species which at the end of the tertiary period or the beginning of the quaternary period immigrated from the neighbouring mountains, it is natural to expect that many endemic species have developed. For all the factors of the lowlands, cosmic as well as terrestrial, differ from those of the highlands; besides, for many plants Transcaspia has been a closed basin enclosed towards the South and East almost everywhere by mountains - the Balchash basin being included - and barred towards the West by the Caspian, and towards the North by the cold.

A third condition favourable for the evolution of endemic species is the dryness of the climate, and consequently a very scattered plant-covering. There is no internecine struggle among the plants themselves, but always sufficient open ground available; they have only the conditions of the environment to contend with (comp. ENGLER 1882, pp. 48, 324; VAHL p. 154).

Moreover it is natural that there should be a close floristic relationship between Transcaspia and the surrounding mountainous parts. This relationship must be closest towards the South, since the country towards the East rises to a far greater height than towards the South where the natural conditions must resemble those of Transcaspia more closely.

Utilising the records of distribution given in the plantlist in chap. 12, we shall endeavour to formulate some conclusions which may be of interest with regard to these questions.

The 768 Transcaspian species enumerated in the plantlist (chap. 12) may be assigned with respect to their distribution outside Transcaspia to the following eight groups (comp. p. 138):

1. Endemic species, 169 or $22 \mathrm{p}$. cent.

2. Species distributed only towards the South (Western Asia), denoted in the list by V: 142 or 18 p. cent.

3. Species distributed only towards the North (Russia) denoted in the list by R: 29 or 4 p. cent.

4. Species distribuled towards the East (High-Asia) denoted in the list by $\mathrm{H}: 83$ or $11 \mathrm{p}$. cent. 
5. Species distributed towards the North and South, but not towards the East, denoled in the list by RV: 56 or 7 p. cent.

6. Species distributed towards the East and South, but not towards the North, denoted in the list by HV: 68 or 9 p. cent.

7. Species distributed towards the East and North, but not towards the South, denoted in the list by HR: 52 or 7 p. cent.

8. Species distributed equally towards the East, North and South, denoted in the list by HRV: 169 or $22 \mathrm{p}$. cent.

From these statistics it follows by addition that 372 species (48 p. cent.) are distributed towards the East, 306 species $(40 \mathrm{p}$. cent.) towards the North, 435 species $(57 \mathrm{p}$. cent.) towards the South, while 169 species (22 p. cent) are endemic.

These figures form the basis of the following conclusions, but their accuracy must only be regarded as more or less comparative. As previously stated, the flora of Transcaspia is insufficiently investigated, and to a still greater extent is this the case with several of the neighbouring countries, especially Persia and Afghanistan. This will naturally involve mistakes in the figures given above. Another source of error is that the species are differently interpreted by the various authors who have described the plants of these countries, and no descriptive floras have been compiled for the coun. tries in question. I have in several cases been obliged to decide according to my own judgment. Of course I believe that I am right in general, but future investigations on the flora of these countries may prove that many species which in this memoir are recorded as common to several territories ought to be divided into more species, each one endemic to its own territory, or that species which are here regarded as endernic to Transcaspia are identical with species in other countries.

The figures given above must therefore be treated with caution, and conclusions drawn from them can only be regarded as rough estimates.

As endemic species I have reckoned not only those 
occurring within the territory defined in chap. 1 , but also species which likewise occur in the Balchash-basin, with natural conditions which to my knowledge are almost identical with those of Transcaspia and without transition. Dsungaria, on the contrary, is left out, and species which are also found there are classed under those with an eastern distribution (denoted H). In my opinion this was necessary, firstly in order to fix a boundary between the eastern and the endemic species; secondly because Dsungaria, though much the same in character as the Balchash-basin, yet for the greater part lies higher and according to Bunge (1880, No. 26) it also differs to some extent in phytogeographical respects from the countries lying to the west.

Nor are plants occurring in the areas north of the Aral Sea regarded as endemic. It is impossible to fix any natural well-defined boundary between Transcaspia in the south and the Kirghiz-steppe in the north, but the boundary I have selected, the $46^{\text {th } 0}$ northern parallel of latitude, cannot be far wrong as it is confirmed in the recently published work by SAwiтch. This memoir shows that several plants which are common in Central Europe also occur in the desert north of the Aral Sea (see p. 5).

The census shows that there are 169 endemic species in the Transcaspian lowlands, that is $22 \mathrm{p}$. cent. of the total number of species. If the area had been differently defined so as to be wider in extent and to include for instance the the whole of West-Turkestan inclusive of the mountains, it is possible that the endemic percentage might be increased, but then it could not be regarded as an expression of, or to be connected with, the homogeneous natural conditions which pervade and have pervaded the Transcaspian lowlands. Since the area has been confined within such narrow limits, we must have a certain right to see such a connection, remembering, however, that the endemism is dependent not only on the number of species formed, but also on the faculty of migration and adaptation of these species. The endemism would have been still greater if the northern boundary of our territory had been moved farther north. If the Kirghiz steppe and the eastern part of Ciscaucasia to the Jergeni 
mountains had been included, a number of Chenopodiaceae (e. g. Nanophytum, Alexandra, Ofaiston), Calligonum spp. and Ammodendron would be regarded as endemic. But as already indicated the natural conditions and the vegetation are rather different in these more northern areas.

The distribution of the endemic species amongst the various growth-forms will be seen from the following table 6 :

Table 6.

\begin{tabular}{l||c|c|c|c|c|c}
\hline & F. & Ch. & H & G & HH & Th \\
\hline \hline & & & & & \\
\hline
\end{tabular}

The endemic species are thus distributed over the growthforms in about the same proportion as the aggregate flora of the desert. The following variations may be of some interest: 1) There are no endemic aquatics and marsh-plants whatever; 2) The endemic species include comparatively greater numbers of fanerophytes and hemicryptophytes than the aggregate species; 3) The endemic species include comparatively fewer annuals than the aggregate.

The first variation is not surprising since it is well known that aquatics and marsh-plants have a wide distribution (see e.g. Drude p. 317).

The last point, that there are comparatively few endemic therophytes, may be explained thus: the therophytes are as a rule spring-plants, and many of these have a wide distribution because over considerable tracts of regions with winter-rains they find almost the same conditions during the short vegetative period. In accordance with this at least 28 p. cent. of the endemic therophytes are late-flowering, in comparison with $21 \mathrm{p}$. cent. of the total therophytes of the whole flora (comp. table 4, p. 162). The second point of variation suggests that the natural conditions of Transcaspia have been favourable to the development of fanerophytes and hemicryptophytes. This does not seem unnatural since the fanerophytes are one of the most prominent and apparently 
one of the best adapted types in the deserts. As regards the hemicryptophytes, about 30 out of 55 endemic species are spring-plants and about 25 are xerophytes (most of which, however, shed their blossoms before July 1. comp. p. 162). Unfortunately I have not been able to draw up sufficiently reliable comparative figures for the whole flora. If what has been stated about the annuals be taken as a starting point, it might be expected that the xerophytic hemicryptophytes were comparatively better represented among the endemic species than the mesophytic ones; but I am unable to decide this question.

The 169 endemic species belong to 83 different genera. Only 7 of these genera are endemic namely:

Borszcowia Bunge. (Chenopodiaceae).

Piptoptera Bunge. (Chenopodiaceae).

Chartoloma Bunge. (Cruciferae).

Cithareloma Bunge. (Cruciferae).

Smirnowia Bunge. (Papilionaceae).

Holopleura Rgl. \& Schm. (Umbelliferae).

Miltianthus Bunge. (Zygophyllaceae).

These genera are monotypic except Cithareloma, which has two species.

Of the two Chenopodiaceae, Borszcowia is closely allied to Suaeda and Bienertia, while Piptoptera is related to Halanthium and other Anabaseae. Thus both belong to groups of plants which are widely distributed in Transcaspia and surrounding countries.

The two Cruciferae are doubtless well-established genera, but both have some near relatives: Chartoloma is closely allied to Isatis, Tauscheria and Sameraria, of which Tauscheria is indigenous in the interior of Asia while the other two occur in western Asia and the eastern Mediterranean countries. Cithareloma is related to a number of oriental Hesperideae, such genera as Farsetia, Eremobium (N. Africa) and Malcolmia.

The validity of the genus Smirnowia likewise seems to be well-founded, in fact it stands amongst the endemic genera 
as one of the most isolated. It is allied to Sphaerophysa which likewise belongs to the interior of Asia, and to Colutea which is distributed from the south of Europe to the western Himalaya.

Holopleura, so far as I can learn, is insufficiently known and there may be some doubt as regards its right to generic rank. Regel says that it is related to Carum and Rumia. Miltianthus is related to Zygophyllum.

Among the endemic species scarcely any one stands isolated. Whichever one be named, it is possible to indicate closely related species in the surrounding countries, more especially those towards the South and South-west. Through more intensive systematic studies one could probably enumerate a series of pairs of vicarious species. Studies of this kind have not been undertaken here, as I have restricted myself to the investigation of the distribution of the genera which contain endemic species in the lowlands of Transcaspia. The following genera have their main distribution in the Mediterranean countries, especially in the eastern ones, and in Nearer Asia whence some of them extend right into Central Asia.

$\begin{array}{lll}\text { Heliotropium } & \text { Pterotheca } & \text { Allium } \\ \text { Lappula } & \text { Scorzonera } & \text { Limodorum } \\ \text { Rochelia } & \text { Convolvulus } & \text { Cistanche } \\ \text { Gypsophila } & \text { Isatis } & \text { Hypecoum } \\ \text { Herniaria } & \text { Malcolmia } & \text { Trigonella } \\ \text { Saponaria } & \text { Peltaria } & \text { Crucianella } \\ \text { Silene } & \text { Sisymbrium } & \text { Haplophyllum } \\ \text { Centaurea } & \text { Crypsis } & \text { Scrophularia } \\ \text { Echinops } & \text { Lepturus } & \text { Tamarix } \\ \text { Jurinea } & \text { Lagochilus } & \text { Cachrys } \\ \text { Rhaponticum } & \text { Phlomis } & \text { Ferula } \\ \text { Matricaria } & \text { Tulipa } & \text { Valerianella }\end{array}$

The following genera seem to have their main distribution more to the East, in the interior of Nearer Asia and in Central Asia: 


$\begin{array}{lll}\text { Eminium } & \text { Salsola } & \text { Ammothamnus } \\ \text { Acanthophyllum } & \text { Cousinia } & \text { Oxytropis } \\ \text { Agriophyllum } & \text { Lachnophyllum } & \text { Calligonum } \\ \text { Anabasis } & \text { Eremostachys } & \text { Aphanopleura } \\ \text { Cornulaca } & \text { Hypogomphia } & \text { Cryptodiscus } \\ \text { Girgensohnia } & \text { Eremurus } & \text { Hyalolaena } \\ \text { Halanthium } & \text { Rhinopetalum } & \text { Psammogeton } \\ \text { Halimocnemis } & \text { Ammodendron } & \text { Zygophyllum }\end{array}$

The following genera have a wide distribution mainly in warm-temperate countries (or tropical):

$\begin{array}{lll}\text { Cleome } & \text { Aristida } & \text { Lactuca } \\ \text { Cuscuta } & \text { Iris } & \\ \text { Euphorbia } & \text { Astragalus } & \end{array}$

There still remain some large widely distributed genera:

$\begin{array}{lll}\text { Artemisia } & \text { Plantago } & \text { Ranunculus } \\ \text { Elymus } & \text { Delphinium } & \text { Carum }\end{array}$

These genera are distributed over so large an area that only a closer study could elucidate where the Transcaspian endemic species of these genera have their nearest relatives.

Leaving out of account the 6 genera last-named which are represented by 9 endemic species, all the rest of the plant genera containing endemic species in Transcaspia have their main distribution towards the South, most of them in the Mediterranean countries and in Western Asia. This is an indication that the flora of Transcaspia is closely allied to the flora of these countries.

The natural orders which contain endemic species can be ascertained by reference to the list of plants (pp. 138-158). More than one example of endemism is to be found in the following families: 
Number

of endemic

Percentage

of total

species

species

Papilionaceae ..... . 31

(24 Astragalus)

.. 36 p. ct.

Compositae

28

(9 Cousinia, 8 Scorzonera). 27

Chenopodiaceae . .

17

(5 Salsola)

. 18

Polygonaceae ...... 14

Umbelliferae . ... 10

(Calligonum)

Liliaceae . ....... 9

Caryophyllaceae... 8

Cruciferae........ 8

Labiatae ... .... 6

Zygophyllaceae... 6

Gramineae........ 5

Orobancheaceae ... 4

Convolvulaceae.... 4

Borraginaceae..... . 3

Ranunculaceae .. .. 3

Rutaceae

Only a few orders contain no endemic species at all, for instance Cyperaceae, Geraniaceae, Plumbaginaceae and none of these orders are rich in species in Transcaspia.

The Papilionaceae take first place as regards endemism, and this is especially due to the numerous species of Astragalus the majority of which belong to the sub-genus Cercidothrix which has bifurcate hairs.

It is characteristic that several of the smaller families are comparatively rich in endemic species, thus half of the Rutaceae and two-thirds of the Orobancheaceae are endemic likewise one-third of the Convolvalaceae, Liliaceae etc. The one species of Araceae and the only Orchid are both endemic.

Endemism in Transcaspia may according to the preceding be denoted as recent, i. e. it has arisen from the development of species within a period not very remote in the geological sense. There are no forms at all standing quite isolated and showing indications of being relicts, but there are endemic species in almost all the natural orders and in several of the larger genera. 
The result we have arrived at does not, therefore, conflict with the theory of the migration of the flora into Transcaspia at the beginning of the quaternary period (see above p. 259). The great number of endemics moreover confirms Engler's assertion that dry areas (he also mentions "the Asiatic Steppes") whence a great number of plant types are excluded give rise to endemic species ${ }^{1}$ ).

Among the non-endemic species of Transcaspia we distinguish between those which have a northerly, those which have an easterly and those which have a southerly distribution (see above p. 260).

Northerly distribution is seen in such species as are distributed from Transcaspia over western Siberia and South Russia. The limit is fixed at about $46^{\circ} \mathrm{N}$. Lat. (see above p. 262). Of such plants there are 306 or $40 \mathrm{p}$. cent. of all the species of Transcaspia; in the plant-list they are the species with the letter $R$ included in the distribution-index. This is no small number, but the importance of the figure is lessened when we remember; (1) that with the exception of 29 of the 306 (9 p. cent.), they are equally distributed towards the east and south; (2) that only 96 species (12 p. cent. of the total number of species) are common to both Transcaspia and the government of Yekaterinoslaw, (these are indicated in the list by $\left.R^{*}\right)$. The first of the above points emphasises that the species occurring towards the North are on the whole widely distributed. The 29 species referred to (those indicated in the list merely by $R$ ) do not even extend far northwards, only one of them (Erodium Hoefftianum) is found as far north as Yekaterinoslaw. Most of them occur on the Kirghiz steppe which as already stated is very similar to Transcaspia. Nor do many of the remaining plants with a northern distribution reach the true steppe or forest areas.

As regards the second point (2), the number of species common to Transcaspia and Yekaterinoslaw, it may be remarked that, with the exception a few Chenopodiaceae and Lycium and Statice, the species common to both countries

1) 1879 p. 10,1882 p. 50 . 
belong to the mesophytic aspect, and that all except Erodium Hoeffitianam are species with a wide distribution; only a small number of them have not also an easterly and a southerly distribution in relation to Transcaspia.

Easterly distribution is seen in the plants occurring in the mountainous countries towards the East, i. e. from Hindukush, Badakshan, Hissar, Pamir to Tibet, Tianshan and Dsungaria (comp. p. 262). This category includes 372 plantspecies or 48 p. cent. of the total species of Transcaspia (in the list the letter $\mathrm{H}$ occurs in their distribution-index). Of these 372 species, 83 or 22 p. cent. are not distributed towards the North and South (indicated in the list by $\mathrm{H}$ alone). Many of the 372 species occur only in Dsungaria, (as to the similarity and dissimilarity between this country and the Balchash-basin see p. 262). As a test of the distribution of Transcaspian lowland plants over really high mountains, I have summed up the species this country has in common with the Pamirs (according to the boundaries given by OLGA Fedtschenko). Such species are denoted in the list by $\mathrm{H}^{*}$, and there are 41 ( $5 \mathrm{p}$. cent. of the total number of species). Only a few of these (Nitraria and a few Chenopodiaceae) belong to the xerophytic aspect. They are all species of wide distribution, and most of them also occur both towards the North and South.

Southerly distribution is seen in plants which beyond Transcaspia are distributed over larger or smaller parts of Afghanistan (Badakshan, however, being reckoned as part of High-Asia), Persia, Asia Minor, Syria and onwards to the Mediterranean countries, including North Africa.

There are 435 plants or $57 \mathrm{p}$. cent. with a southerly distribution - their distribution-index in the list contains the letter $\mathrm{V}$ - against 40 p. cent. with a northerly and 48 p. cent. with an easterly distribution. Thus more than half the plants of the Transcaspian lowlands have a southerly distribution. Of the 435 species, 142 or 33 p. cent. (18 p. cent. of the total number of species) have no distribution towards the North or East, they are thus Western-Asiatic species which avoid the higher mountains and the higher degrees of latitude. (In the list they are indicated by $\mathrm{V}$ alone). Recapitulating the 
above, we have that the "northerly" plants include only 9 p. cent. which are exclusively northern, the "easterly" ones 22 p. cent. exclusively eastern, while the "southerly" plants include $33 \mathrm{p}$. cent. exclusively distributed towards the South.

These figures as in the case of the percentage for the total distribution, show that the Transcaspian lowlands are most closely related to the countries lying towards the South and South-West, and most distantly related to the countries lying towards the North. This is the case though the Transcaspian lowlands towards the North are open and without any natural boundary, while in every direction towards the South they are hemmed in by mountains.

This result is further confirmed if we take into consideration the species which the Transcaspian lowlands have in common with Syria and Palestine (166 species, Post, indicated in the list by $\mathrm{V}^{*}$ ), or with Egypt (91 species, Ascherson \& Schweinfurth); that is respectively 22 and 12 p. cent. of the total number of species. About one-third of these (Syria 30, Egypt 29 p. cent.) do not occur either east or north of Transcaspia, and less than half of them (Syria 39, Egypt 41 p. cent.) are widely distributed species which are also found north and east of Transcaspia.

Compare with this what has been stated about species common to Yekaterinoslaw and to Pamir. Here almost all the species in common have a wide distribution; this community therefore indicates a more distant relationship than that between areas with species in common which show a more limited distribution.

Though derived from imperfect and somewhat scanty materials, our figures point in the right direction, as they have shewn us that the Transcaspian lowlands in their floristic as well as their biological aspects (comp. above p. 160) are more closely related to the countries towards the South. This result will probably be further confirmed by future systematic investigations within the individual genera or families. Such investigations are already being carried on, and we may illustrate them by a short summary of Professor Kusnezow's interesting investigations on Rindera Pall., a genus of Borraginaceae. 
As the result of careful morphological and anatomical studies of the species of Rindera, it appears that the subgenus Mattia is the "central-lype" of the genus, from which the sub-genera Cyphomattia and Eurindera have developed each in its own way.

KusNezow presumes that the ancestors of Rindera (and Paracaryum) at the beginning of the tertiary period were widely distributed over the earth; the last remnants of them are the two existing monotypes: Tysonia in south-eastern Africa and Myositidium in New Zealand.

During the latter half of the tertiary period Rindera must have been widely distributed in the Mediterranean countries (from Spain to Central Asia), and the genus at that period had two sub-genera: Mattiaria (now one species) and Mattia (now 6 species). These seven species are constant with no intervening transitions, and they have small and well-defined areas of distribution from Algeria to Persia, - they must be regarded as relict forms.

At the end of the tertiary period when the lowlands were drying up, Kusnezow considers that the five species of the sub-genus Eurindera were evolved in the mountains of Turkestan; these species are harder to distinguish than those of Mattia. One of them, Rindera tetraspis, had the faculty of migration so that after the drying-up of the Transcaspian lowlands it was able to propagate here as well as in Western Siberia, South Russia and Ciscaucasia.

Simultaneously with Eurindera, there came into existence in Nearer Asia from Mattia the two species of the sub-genus Cyphomattia of which one, Rindera lanata, is very polymorphic and widely distributed. 


\section{LITERATURE}

1. Adamowicz, L.: Die Vegetationsverhältnisse der Balkanländer (Engler u. Drude, Die Veg. d. Erde XI). Leipzig 1909.

2. Aggeenko: Vegetation of the steppes near Balchash. (In Russian). (Scripta bot. hort. Univ. Imp. Petrop I). 1886.

3. Aitchison, J.E. T.: The botany of the Afghan delimitation commission. (Transact. Linn. Soc. London 2 Ser. 3). 1887.

4. Anikin, W.: Ueber Schwankungen im Bestande der Salze der Salzseen des Kaspi-Bassins. (Annuaire géol, et minér. de la Russie, réd. par N. Kristafowitsch III). 1898-99.

5. Antonow, A. A.: On the plant formations of the Transcaspian territory. (In Russian). (Scripta bot. hort. Univ. Imp. Petrop. III. Beil.) 1892.

6. Ascherson et $\mathrm{Schweinfurth:} \mathrm{Illustration} \mathrm{de} \mathrm{la} \mathrm{flore} \mathrm{d'Egypte} \mathrm{(Mém.}$ Inst. Egypt. II). Le Caire 1889.

7. Atlas climatologique de l'Empire Russe, publié par l'observatoire central Nikolas. St. Pétersbourg 1900.

8. Baer, K. E.: Kaspische Studien (Bull. Ac. Imp. Sc. St. Pb. 1855).

9. Barbot-de-Marny, N. P.: Itinéraire geologique à travers le Manghychlak et l'Ousturte au Turkestan (Trav. Exp. Aralo-Casp. VI). St. Petersburg 1899.

10. Basiner: Gedrängte Darstellung der Herbstregetation am Aral-See und im Chanata Chiwa. (Bull. phys.-math. St. Pb. II). 1844.

11. Basiner: Naturwissenschaftliche Reise durch die Kirgisensteppe nach Chiwa. (Beitr. z. Kenntn. d. russ. Reiches XV). St. Petersburg 1848.

12. Békétoff: Sur la flore du gouvernement de Yekaterinoslaw. (Scripta bot. hort Univ. Imp. Petrop. I). 1886.

13. B erg, L.: Zur Morphologie der Ufer des Aral-Meeres (In Russian). (Annuaire géol. et minéral. de la Russie, publ, par N. Kristafowitsch V). St. Petersburg 1902.

14. Berg, L.. Der Aral-See (In Russian). (Wissens. Ergebn. der Aralsee-Exp., Mittheil. d. turkestan. Abt. d. Kais. Rus. geogr. Ges. V). St. Petersburg 1908. 
15. Bergen, I. Y.; Transpiration of Spartium junceum and other xerophytic shrubs. (Bot. Gazette 36). 1903.

16. Bernatsky, J.: Über die Halophytenvegetation des Sodabodens im ungarischen Tieflande (Ann. mus. nat. Hung. III). Buda-Pest 1905.

17. Bessey, E. A.: Vegetationsbilder aus Russisch Turkestan. (Karsten u. Schenk, Vegetationsbilder, 3. R, 2). Jena 1905.

18. Boirivant, A.: Recherches sur les organes de remplacement chez les plantes. (Anm. Sc. nat. Bot. 8 Sér. 6). 1897.

19. Boissier, E.: Flora orientalis. Genevæ et Basileæ 1867-1881.

20. Borszczow, I.: Ueber die Natur des Aralo-Caspischen Flachlandes. (Würzburger naturwiss. Zeitschr. I). 1860.

21. Borzczow, I.: Contribution to the geography of plants in the AraloCaspian countries (In Russian). Sapiski Imp. Akad. Nauk No. 1, Appendix). St. Petersburg 1865.

22. Britzke, O.: Ueber den jährlichen Gang der Verdunstung in Russland. (Repert. f. Meteorol. herausgeg. v. d. Kais. Akad. d. Wissensch. 17). St. Petersburg 1894.

23. Bunge, A.: Beitrag zu Kenntniss der Flor Russlands und der Steppen Centralasiens. Alexandri Lehmanni reliquiae botanicae. (Mém. savants étrangers VII). St. Petersburg 1851.

24. Bunge, A.: Tentamen generis Tamaricum species accuratius definiendi. Dorpat 1852.

25. Bunge, A.: Generis Astragali species gerontogeae 1-2. (Mém. Ac. Imp. Sc. St. Pétersbourg XI 1868, XV 1869).

26. Bunge, A.: Enumeratio Plantaginearum Salsolacearumque centrasiaticarum (Acta horti Petrop. VI). 1880.

27. Bunge, A.: Pflanzengeographische Betrachtungen über die Familie der Chenopodiaceen. (Mém. Ac. Imp. Sc. St. Pétersbourg 7 sér. 27). 1880.

28. Bunge, A.. Astragaleae (Fedtschenko's journey in Turkestan III (Isvest. Imp. obs. liubit jest. antrop. i ethnogr. 26). St. Petersburg 1880.

29. Burgerstein, A.: Die Transpiration der Pflanzen. Jena 1904.

30. Cannon, W. $A_{1}$ : On the water conducting systems of some desert plants (Bot. Gazette 39). 1905.

31. Capus, G.: Climat et végétation du Turkestan. (Ann. sc. nat. Bot. 6 sér. 15). 1883.

32. Clements, F. E.: Research methods in Ecology. Lincoln, Nebraska 1905.

33. Cowles, H. C.: The causes of vegetative cycles (Bot. Gazette 51). 1911.

34. Crampton, C. B.. The vegetation of Caithness, considered in relation to geology (Com. for the survey and study of British veget.). 1911.

35. Drude, O.: Handbuch der Pflanzengeographie. Stuttgart 1890.

36. Duval Jouve: Histotaxie des feuilles des Graminées. (Anm, sc. nat. Bot. 6 Sér. 1). 1875.

37. Eichwaldt: Plantarum novarum v. minus cognitarum in itin. caspiocaucasico I-II. Vilnae 1831-1833.

38. Engler, A.: Versuch einer Entwickelungsgeschichte der Pflanzenwelt. 1-2. Leipzig $1877-1882$. 
39. Engler, A.: Die Pflanzenwelt Afrikas, insbesondere seiner tropischen Gebiete I. (Engler u. Drude. Die Veg. der Erde IX). Leipzig 1910.

40. Fedtschenko, O. A.: List of Plants collected in Turkestan in the years 1869, 1870, and 1871 (In Russian). (A. P. Fedtschenko's journey in Turkestan). (Isvest. Imp. obs. liub. jest. antrop. i ethnogr. 103). Moskva 1903.

41. Fedtschenko, O. A.: Flore de Pamir (Acta horti Petrop 21. 1903), with Supplément 1-4 (A. H. Petrop. 24, 1904-27, 1909).

42. Fedtschenko, O. A. und B. A.: Conspectus florae turkestanicae IXXVI. (Beih. Bot. Centralbl. 18-26). 1906-1910.

43. Ficker, H. v.: Zur Meteorologie von West-Turkestan. (Denkschr. d. Kais. Ak. Wiss., math.-nat. Cl. 81). Wien 1908.

44. Fitting, Hans: Die Wasserversorgung und die osmotischen Druckverhältnisse der Wüstenpfianzen. (Zeitschr. f. Bot. 3). 1911.

45. Gain, E.: Rôle physiologique de l'eau dans la végétation (Ann. sc. nat. Bot. 7 sér. 20). 1894.

46. Gain, E.: Action de l'eau du sol sur la végétation (Rev. gén. de Bot. 7). 1895.

47. Gernet, G. A, v.: Notizen ueber den Bau des Holzkoerpers einiger Chenopodiaceen. (Bull. soc. nat. Moscou 1859).

48. Gheorghieff, S.: Beitrag zur vergleichenden Anatomie der Chenopodiaceen. (Bot. Centralbl. 30-31). 1887.

49. Grisebach, A.: Die Vegetation der Erde 1-2. Leipzig 1872.

50. Grisebah, A.: Gesammelte Abhandlungen. Leipzig 1880.

51. Gruner, L.: Zur Charakteristik der Boden- und Vegetationsverhältnisse des Steppengebiets und der Dniepr- und Konka-Niederung underhalb Alexandrowsk. (Bull. soc. nat. Moscou 1872).

52. Hackel, E.: Über einige Eigentümlichkeiten der Gräser trockener Klimate. (Verhandl. zoolog.-botan. Ges. Wien 40). 1890.

53. Halacsy: Conspectus florae Graecae. 1-3. Lipsiae 1901-1904.

54. Hallier, H.: Versuch einer natürlichen Gliederung der Convolvulaceen auf morphologischer und anatomischer Grundlage. (Englers Jahrb. 16).

55. Hann, J.: Handbuch der Klimatologie. Stuttgart 1897.

56. Heinricher, E.: Über isolateralen Blattbau (Pringsh. Jahrb. 15). 1884.

57. Henslow, G.: The origin of plant-structures by self-adaptation to the environment, exemplified by desert or xerophilous plants. (Journ. Lin. Soc. London 30). 1894.

58. Herder, F. v.: Die neueren Beiträge zur Pflanzengeographischen Kenntniss Russlands. (Engl. bot. Jahrb. 9-10). 1888-1889.

59. Hochreutiner, B. G. P.: Le Sud-Oranais. (Ann. du Conserv. et du Jard. Bot. Genève. 7-8). 1904.

60. Ismailsky, A.: Wie ist unsere Steppe ausgetrocknet? (Selsk. Chosj: i Ljesow. 1893). Abstracted in Kusnezow 1899.

61. Iwtschenko, A.: La région périphérique du paysage des déserts en partie N. de la steppe de Kirghiz. (Ann. géol. et minér. de la Russie, réd. par. N. Kristafovitsch V). 1902. 
62. Jönsson, B.: Zur Kenntniss des anatomischen Baues der Wüstenpflanzen (Lunds Univ. Årsskr. 38). Lund 1902.

63. Jönsson, B.; Om vikariat inom växtriket vid näringheredning. Lund 1910.

64. Karpinski: Übersicht der physiko-geographischen Verhältnisse des europ. Russlands während der verflossenen geol. Perioden. (Beitr. z. Kenntn. d. russ. Reiches 3 F. 4). 1888.

65. Kersnowsky, I. A.: La direction et la vitesse du vent sur la surface de l'Empire Russe. (Mém. Ac. Imp. Sc. St. Pétersbourg 8 Sẻr. 2). 1895.

66. Köppen, W.: Versuch einer Klassiflkation der Klimate (Geogr. Zeitschr. 6). 1901.

67. Korshinsky, S.: Sketches of the vegetation of Turkestan (In Russian) 1-3. Transcaspia, Ferghana and Alai. (Mém. Ac. Imp. Sc. St. Pétersbourg 8 Sér. 4). 1896.

68. Korshinsky, S.: Fragmenta florae turkestaniae. (Bull. Ac. Imp. Sc. St. Pétersbourg 5 Sér. 9). 1898.

69. Kostytscheff, P.: Ueber den Zusammenhang zwischen dem Boden und einigen Pflanzenformationen. (Scripta bot. hort. Univ. Imp. Petrop. III, Beilage). 1892.

70. Krassnow, P.: Bemerkungen über die Vegetation des Altai. (Ibid. I) 1886. Abstracted in Herder 1888.

71. Krassnow, P.: Geobotanische Untersuchungen in den Kalmükensteppen. (Nachr. Kais. Russ. Ges. 22. 1886). Abstracted in Herder 1889.

72. Krassnow, P.: Steppes de la Russie méridionale: origine, évolution, flore. (Ann. de géogr. $3^{0}$ année). Paris 1894.

73. Krassnow, P.: Die Grassteppen der nördlichen Halbkugel. (Trud. Geogr. Otd. Imp. Obs. ljub. jest. Antrop. i Geogr. V). 1894. Abstracted in Kuznezow 1899.

74. Kusnezow, N. I.: Übersicht der in den Jahren 1891-94 über Russland erschienenen phytogeographischen Arbeiten. (Engl. Jahrb. 26). 1899.

75. Kusnezow, N. I.: On the origin of the xerophytic mountain-flora of Caucasus (In Russian) (Trav. Mus. bot. Ac. Imp. Se. St. Pétersbourg VII). 1910.

76. Lace, I. H., and Hemsley, W. B.: A Sketch of the vegetation of British Baluchistan. (Journ. Lin. Soc. London 28). 1890.

77. Lebedour, C. F. a.: Flora rossica. Stuttgartiae 1842-1853.

78. Lehmann, A.: Reise nach Buchara und Samarkand in den Jahren 1841 und 1842. Bearb. v. G. v. Helmersen. (Beitr. z. Kenntn. d. Russ. Reiches 17). 1852.

79. Lipsky, W. I.: Contributio ad floram Asia mediae 1-3 (Acta horti Petrop. 18, 22, 26). 1900-1909.

80. Lipsky, W. I.: Flora Asiae mediae (Acta hort. Tiflis VII). 1902.

81. Lipsky, W. I.: La végétation forestière du Turkestan (In Russian) (Trudy po ljesn. opytnomu delo v Rossiji 30). 1911.

82. Litwinow, D.: Florae turkestanicae fragmenta 1-2. (Trav. Mus. bot. Ac. Imp. Sc. St. Pétersbourg I 1901, VII 1909).

83. Litwinow, D.: Plantae turcomaniae 1-2. (ibid. I 1902, III 1907). 
84. Livingston, B. E.: The relation of soils to natural vegetation in Roscommon and Crawford counties, Michigan. (Bot. Gaz, 39). 1905.

85. Livingston, B. E.. The relation of desert plants to soil moisture and to evaporation (Carnegie Inst. Publ. No. 50). Washington 1906.

86. Lloyd, F. E.: The physiology of stomata. (Carnegie Inst. publ. No. 82). Washington 1908.

87. Mac Dougal, D. T.: Botanical features of North American deserts. (Carnegie Inst. publ. No. 99). Washington 1908.

88. Mac Dougal, D. T.: Influence of aridity upon the evolutionary development of Plants. (The Plant World 12). 1909.

89. Malme, G. O. A.: Om förgrenade årsskott hos träd och buskar. (Arkiv för Bot., utg. af K. Svenska Vet. Akad. 3). 1904.

90. Marloth, R.: Zur Bedeutung der Salz abscheidenden Drüsen der Tamariscineen. (Ber. d. deutschen bot. Ges. 5). 1887.

91. Martjanow, N.: Materialien zur Flora des Minusinskischen Landes. 1882. Abstracted in Herder 1888.

92. Massart, J.: Une voyage botanique dans le Sahara, (Bull. soc. roy. de Bot. de Belgique 37). 1898.

93. Matenaers, F. F.: Campbells Anleitung zur zweckmässigsten Bodenbearbeitung als Grundlage für alle Fruchtbarkeit. Berlin 1908.

94. Mentz, A.: Studier over danske Hedeplanters Økologi. I. GenistaTypen. (Botanisk Tidsskrift 27). København 1906.

95. Meschayeff, V.: Ueber die Anpassungen zum Aufrechthalten der Pflanzen und die Wasserversorgung bei der Transpiration. (Bull. soc. nat. Moscou 57), 1882.

96. Middendorff, A. v.: Einblikke in das Ferghana Thal. (Mém. Ac. Imp. Sc. St. Pétersbourg 7 Sér. 29). 1881.

97. v. Minkwitz, S. A., and v. Knorring, O. E.: The vegetation of the district of Tshimkent (In Russian) (Trudy potshven.-botan. expedit. po issledovan. kolonisaz, raion. Asiatskoi Rossiji II). St. Petersburg 1912.

98. Moss, C. E.: Geographical distribution of vegetation in Sommerset. (Geogr. Journal London 1907).

99. Muschketow, I. W.: Turkestan I. St. Petersburg 1886 (In Russian).

100. Nazarow, P. S.: Recherches zoologiques des steppes Kirguiz. (Bull. soc. nat. Moscou 1886-1887).

101. Olufsen, O.: Sommeren i Centralasien fra Kaspihavet til Ferghanas Ostgrænse. (Geogr. Tidsskrift 1901-1902). København.

102. Olufsen, O.: Den anden danske Pamir-Expedition. Rejse paa Amu Darja til Khiva (Geogr. Tidsskrift 15). København.

103. Palezkij, $V_{1}$ : On the settling of the sand-drift along the railroad of Inner Asia (In Russian) (Ljesnoi Journal 31). St. Petersburg 1901.

104. Palezkij, V.: On the settling of the sand-drift along the railroad of Inner Asia (In Russian) (Ljesopromyshlennij vjestnik 10 No. 31). Moskva 1908.

105. Pallas, P.: Reise durch verchiedene Provinzen des Russischen Reichs. 1-3. Frankfurt u. Leipzig 1776-1778.

106. Patschoskij, J.: Recherches florographiques et phytogéographiques sur 
les steppes des Kalmouks. (In Russian) (Sapiski Kiewsk. obs. jestest. 16). Kiew 1892.

107. Pick, H.: Beiträge zur Kenntnis des assimilirenden Gewebes armlaubiger Pflanzen (Diss.). Bonn 1881.

108. Post: Flora of Syria, Palæstine, and Sinai. Beirut 1896.

109. Price, S. Reginald: The roots of some North African desert grasses. (The New phytologist X). 1911.

110. Raciborski, M.: Ueber die Verzweigung. (Ann. jard. bot. Buitenzorg 17). 1901.

111. Radde, G.: Transcaspien und Nord-Chorassan. (Peterm. Mitth. 27, Ergănzungsbd.). 1899.

112. Radde, G.: Grundzüge der Pflanzenverbreitung in den Kaukasusländern. (Engler u. Drude, Die Veget. d. Erde III). Leipzig 1899.

113. Ramann, E.. Bodenkunde. Berlin 1905.

114. Raunkiær, C.: Types biologiques pour la géographie botanique. (Bull. Ac. Roy. Sc. Danemark 1905), Copenhague.

115. Raunkiær, C.: Dansk Exkursionsflora 2. Udg. København og Kri stiania 1906.

116. Raunkiær, C.: Planterigets Livsformer og deres Betydning for Geografien. København og Kristiania 1907.

117. Raunkiær, C.: Livsformernes Statistik som Grundlag for biologisk Plantegeografi. (Botanisk Tidsskrift 29). København 1908. Translated in Beih. Bot. Centralbl. 87. 1910. („Statistik der Lebensformen als Grundlage für die biologische Pflanzengeographie").

118. Regel: Descriptiones plantarum novarum v. minus cognitarum in reg. turkestan. (Acta horti Petrop. I-VII). St. Petersburg 1873-1880.

119. Regel: Flora turkestanica I. (A. P. Fedtschenko's Journey in Turkestan). (Isvest. Imp. obs. liub. jest. antrop. i ethnogr. 21). Moskva 1876.

120. Regel: Descriptiones plantarum novarum (A. P. Fedtschenko s Journey in Turkestan). (Ibid. 34). St. Petersburg 1882.

121. Regel, et Herder, F. v.: Enumeratio plantarum in reg. cis- et transiliensibus a Semenovio a. 1857 collect. (Bull. nat. Moscou 1864-1870).

12\%. Richthofen, Freiherr v.: China. Berlin 1877-1883.

123. Rind ow sky, Th. : Zur Histologie der Gattung Calligonum L. (In Russian). Kiew 1875. Abstracted in Just, Jahresber. 1875 p. 394.

124. Rodsewitsch: The forest vegetation in Transcaspia (In Russian). Abstracted in Lipsky 1902.

125. Romanowski, G.: Materialien zur Geologie von Turkestan. I. Geologische und paläontologische Uebersicht des nordwestlichen Thian-Shan und des südostlichen Theiles der Niederung von Turan. St. Petersburg 1880.

126. Romanovski, G., et Mouchketow, I.: Carte géologique du Turkestan russe, dressée en 1881. St. Pétersbourg 1886.

127. Ross, H.: Beiträge zur Kenntnis des Assimilationsgewebes und der Korkentwickelung armlaubiger Pflanzen (Diss.). Freiburg 1887.

128. Rykatchew, M.: Annales de l'observatoire physique central Nicolas, publié par. St. Pétersbourg 1897-1906. 
129. Die Sande Kara-Kum in ihren Beziehungen zur centralasiatischen Eisen bahn. (Peterm. geogr. Mittheil. 1878).

130. Sawitsh, V. M.: In the Caspian steppes and deserts beyond Ural (In Russian) (Acta horti Petrop. 28). St. Petersburg 1908.

131. Schedae ad herbarium florae Rossicae a Mus. Bot. Ac. Imp. Sc. Petrop. editum 1-VI. 1898-1908.

132. Schimper, A. F. W.: Pflanzengeographie auf physiologischer Grundlage. Jena 1898.

133. Schube, P.: Beiträge zur Kenntniss der Anatomie blattarmer Pflanzen (Diss.). Breslau 1885.

134. Schwarz, F. v.: Turkestan, die Wiege indogermanischen Völker. Freiburg i B. 1900 .

135. Semenow, M. P. de: La Russie extra-européenne et polaire. (Commission Imp. de Russie à l'expos. univ. de 1900). Paris 1900.

136. Sjögren, H.: Ueber das diluviale, aralokaspische Meer und die nordeuropäische Vereisung. (Jahrb. d. K. K. geol. Reichsanstalt 40). Wien 1891.

137. Solereder, H.: Systematische Anatomie der Dikotyledonen. Stuttgart 1899. Ergänzungsband 1908.

138. Solger, F., Graebner, P., Thienemann, Z., Speiser, P., Schulze, F. W. O.: Dünenbuch. Stuttgart 1910.

139. Spalding, V. M.: Botanical relations of certain desert shrubs I. The creosote bush (Covillea tridentata) in its relation to water supply. (Bot. Gazette 38). 1904.

140. Spalding, V. M.: Distribution and movement of desert plants. (Carnegie Inst. Publ. No. 113). Washington 1909.

141. Stefani, Forsyth Major et Barbey: Samos. Etude géol., paléont. et botanique. Lausanne 1892 .

142. Tanfiljew. G. I.: Main features of vegetation of Russia (In Russian) In: Warming, Plantesamfund, translated by A. G. Genkel. St. Petersburg 1903.

143. Tanfiljew, G. I.: Die südrussischen Steppen. (Résultats scientif. du congrès internat. de Bot.). Vienne 1905.

144. Thornber, J. J.: Vegetation groups of the desert laboratory domain. (The Plant world 12). Tuczon 1909.

145. Trautvetter, E. R. a.: Enumeratio plant. songoric. a Schrenk lect. (Bull. soc. nat. Moscou 1860-1867).

146. Tschirch, A.: Beiträge zu der Anatomie und dem Einrollungsmechanismus einiger Grasblätter. Pringsh. Jahrb. 13). 1882.

147. Vah1, M.: Madeiras Vegetation. København og Kristiania 1904. Translated in Engl. Bot. Jahrb. 36. 1905 (,Über die Vegetation Madeiras").

148. Velenowsky: Vergleichende Morphologie der Pflanzen. 1-2. Prag $1905-1907$.

149. Vesque, J.: Contributions à l'histologie de la feuille des Caryophyllinées. (Aunn. sc. nat. Bot. Sér. 6, 15). 1883.

150. Volkens, G.: Die Flora der ägyptisch-arabischen Wüste. Berlin 1887. 
151. Volkens, G.: Chenopodiaceae (Engler u. Prantl, Die nat. Pflanzenfam.). 1892.

152. Walther, J.: Vergleichende Wüstenstudien in Transcaspien und Buchara. (Verh. d. Ges. f. Erdk. Berlin 35). 1898.

153. Walther, J.: Das Gesetz der Wüstenbildung. Berlin 1900.

154. Warming, E.: Botaniske Exkursioner. I. Fra Vesterhavskystens Marskegne (Vidensk. Meddel. naturhist. Foren. i København 1890).

155. Warming, E.: Lagoa Santa. (K. Danske Vid. Selsk. Skr. 6. R., naturvid. og math. Afd., VI 3). København 1892.

156. Warming, E.: Plantesamfund. København 1895.

157. Warming, E.: Halofytstudier. (K. Danske Vid. Selsk. Skr. 6. R., naturvid. og math. Afd. VIII, 4.). Kebenhavn 1897.

158. Warming, E.: Klitterne (Dansk Plantevæxt 2). København og Kristiania $1907-1909$.

159. Warming, E., assisted by M. Vahl: Oecology of plants, prepared for publ. in english by Groom and Balfour. Oxford 1909.

160. Weyland, J.: Beiträge zur anatomische Charakteristik der Galegeen. Bull. hb. Bois. I, App. 3). Genève 1893.

161. Wiesner: Der Lichtgenuss der Pflanzen. Leipzig 1907.

162. Wild, H.: Die Temperaturverhältnisse des russischen Reiches (Suppl. z. Repert. f. Meteorologie, herausgeg. v. d. Kais. Akad. der Wiss.). St. Petersburg 1881.

163. Wild, H.: Die Regen-Verhältnisse des russischen Reiches (ibid.) St. Petersburg 1887.

164. Willkom m, H. M.: Die Strand- und Steppengebiete der iberischen Halbinsel und deren Vegetation (Diss.). Leipzig 1852.

165. Willkomm, H. M.: Grundzüge der Pflanzenverbreitung auf der iberischen Halbinsel. (Engler u. Drude, Veget. d. Erde I). Leipzig 1896.

166. Woenig: Die Pusztenflora der grossen ungarischen Tiefebene. Leipzig 1899.

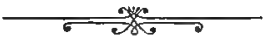



Missing Page 
Missing Page 


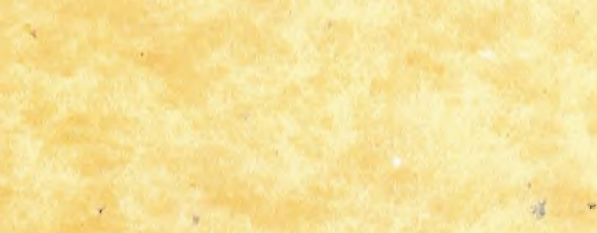

